EUNICE BARBOSA

\title{
EVOLUÇÃO DO USO DO SOLO RESIDENCIAL NA ÁREA CENTRAL DO MUNICÍPIO DE SÃO PAULO
}

\author{
Dissertação apresentada à Escola Politécnica da Universidade de \\ São Paulo para obtenção do título de Mestre em Engenharia. \\ Área de Concentração: \\ Engenharia de Construção Civil e Urbana \\ Orientador: \\ Prof. Dr. Witold Zmitrowicz
}

SÃO PAULO

2001 
AGRADECIMENTOS:

Em primeiro lugar agradeço ao Prof. Dr. Witold Zmitrowicz pelo incentivo e orientação dados à elaboração deste trabalho.

Agradeço também aos meus familiares e amigos, especialmente os da FAUUSP e da EPUSP pelo apoio recebido. 


\section{Lista de tabelas}

\section{A. Tabelas sobre evolução dos bairros:}

Aclimação - pg.85

Água Branca - pg.86

Alto da Lapa - pg. 88

Alto de Pinheiros - pg. 89

Avenida Paulista - pg. 90

Barra Funda - pg. 92

Bela Vista - pg. 94

Belém - pg. 96

Boaçava - pg. 97

Bom Retiro - pg. 98

Brás, Glicério, Mercado e Carmo - pg. 100

Cambuci - pg. 102

Campos Elíseos - pg. 103

Cerqueira César - pg. 104

Canindé, Pari - pg. 106

Cidade Nova - pg. 107

Consolação - pg. 109

Higienópolis - pg. 111

Ibirapuera, Jardim - Lusitânea, Vila Nova Conceição - pg. 113

Indianópolis, Moema - pg. 114

Itaim, Vila Olímpia - pg. 115

Jardim América - pg. 116

Jardim Europa - pg. 117

Jardim Paulista- pg. 118

Jardim Paulistano, Avenida Faria Lima - pg.120

Lapa - pg. 122

Liberdade - pg. 124

Luz - pg. 125

Moóca, Parque da Moóca, Vila Monumento - pg. 127

Pacaembú, Sumaré, Sumarezinho - pg. 129

Paraíso - pg. 131

Perdizes - pg. 132

Pinheiros - pg. 133

Planalto Paulista - pg. 135

Pompéia - pg. 136

Santa Cecília - pg. 137

Santa Efigênia - pg. 138

Vila Buarque - pg. 140

Triângulo e Adjacências - pg. 142

Vila Ipojuca, Campos de Escolástica - pg. 145

Vila Leopoldina, Hamburguesa, Vila Anastácio - pg. 146

Vila Madalena, Vila Ida - pg. 148

Vila Mariana, Vila Clementino - pg. 149

Vila Romana - pg. 150

B. Outras tabelas:

Viagens por transporte individual na Grande São Paulo 1967/1997 - pg. 171

Taxa de Motorização na Grande São Paulo 1967/1997 - pg. 171 
Lista de figuras:

A. Mapas do sistema viário de bairros:

Aclimação - pg.85

Água Branca - pg.86

Alto da Lapa - pg. 88

Alto de Pinheiros - pg. 89

Avenida Paulista - pg. 90

Barra Funda - pg. 92

Bela Vista - pg. 94

Belém - pg. 96

Boaçava - pg. 97

Bom Retiro - pg. 98

Brás, Glicério, Mercado e Carmo - pg. 100

Cambuci - pg. 102

Campos Elíseos - pg. 103

Cerqueira César - pg. 104

Canindé, Pari - pg. 106

Cidade Nova - pg. 107

Consolação - pg. 109

Higienópolis - pg. 111

Ibirapuera, Jardim - Lusitânea, Vila Nova Conceição - pg. 113

Indianópolis, Moema - pg. 114

Itaim, Vila Olímpia - pg. 115

Jardim América - pg. 116

Jardim Europa - pg. 117

Jardim Paulista- pg. 118

Jardim Paulistano, Avenida Faria Lima - pg.120

Lapa - pg. 122

Liberdade - pg. 124

Luz - pg. 125

Moóca, Parque da Moóca, Vila Monumento - pg. 127

Pacaembú, Sumaré, Sumarezinho - pg. 129

Paraíso - pg. 131

Perdizes - pg. 132

Pinheiros - pg. 133

Planalto Paulista - pg. 135

Pompéia - pg. 136

Santa Cecília - pg. 137

Santa Efigênia - pg. 138

Vila Buarque - pg. 140

Triângulo e Adjacências - pg. 142

Vila Ipojuca, Campos de Escolástica - pg. 145

Vila Leopoldina, Hamburguesa, Vila Anastácio - pg. 146

Vila Madalena, Vila Ida - pg. 148

Vila Mariana, Vila Clementino - pg. 149

Vila Romana - pg. 150

B. Outros mapas:

Área de estudo - pg. 7

Principais shoppings do Município de São Paulo em 2000 - pg. 73 
Áreas estritamente residenciais 1922-1951 - pg. 76

Áreas estritamente residenciais (apto permitido) 1922-1951 - pg. 77

Áreas estritamente residenciais 1952-1972 - pg. 78

Áreas estritamente residenciais (apto permitido) 1952-1972 - pg. 79

Áreas estritamente residenciais (lei de ruídos) - pg. 80

Áreas estritamente residenciais criadas em 1972 - pg. 81

Áreas estritamente residenciais vigentes em 1999 - pg. 82

Perímetros dos bairros - pg. 83

Evolução da área urbanizada - pg. 84

Uso do solo 1890 - pg. 152

Uso do solo 1922 - pg. 153

Uso do solo 1952 - pg. 154

Uso do solo 1972 - pg. 155

Uso do solo 1999 - pg. 156

Transformações 1860-1890 - pg. 160

Transformações $1890-1922$ - pg. 161

Transformações 1922 -1952 - pg. 162

Transformações 1952 -1972 - pg. 163

Transformações 1972 -1999 - pg. 164

Transformações 1860 -1999 - pg. 165

Valor venal - total por setor fiscal 1938 - pg. 172

Valor venal - total por setor fiscal 1966 - pg. 173

Valor venal - total por setor fiscal 1987 - pg. 174

Áreas estritamente residenciais (apto não permitido) 1922-1999 revogadas e vigentes - pg. 186

C. Fotos:

Água Branca 1999 (foto da autora) - pg. 87

Alto de Pinheiros 1999 (foto da autora) - pg. 89

Avenida Paulista 1906 (foto Guilherme Gaensly - Acervo do Arquivo do

Estado, proibida reprodução) - pg. 91

Avenida Paulista 1988 (foto da autora) - pg. 91

Barra Funda 1999 foto 1 (foto da autora) - pg. 93

Barra Funda 1999 foto 2 (foto da autora) - pg. 93

Bela Vista 2001 (foto da autora) - pg. 95

Bom Retiro 2001 (foto da autora) - pg. 99

Cerqueira César 2001 (foto da autora) - pg. 105

Pari 2001 (foto da autora) - pg. 106

Cidade Nova 2001 - foto 1 (foto da autora) - pg. 108

Cidade Nova 2001 - foto 2 (foto da autora) - pg. 108

Cidade Nova 1887 (foto Militão - Acervo do Arquivo do Estado, proibida reprodução) - pg. 108

Consolação 1860 (foto Militão - Acervo do Arquivo do Estado, proibida

reprodução) - pg. 110

Higienópolis 1988 (foto da autora) - pg. 112

Jardim Paulista 2001 (foto da autora) - pg. 119

Jardim Paulistano 2000 (foto da autora) - pg. 121

Av. Faria Lima 2000 (foto da autora) - pg. 121

Lapa 2001 (foto da autora) - pg. 123

Pacaembú 2001 (foto da autora) - pg. 130

Pinheiros 2000 (foto da autora) - pg. 134 
Pompéia 1999 (foto da autora) - pg. 136

Santa Efigênia 2000 (foto da autora) - pg. 139

Vila Buarque 2001 (foto da autora) - pg. 141

Triângulo (r. São Bento 1906 - foto Guilherme Gaensly - Acervo do Arquivo do Estado, proibida reprodução) - pg. 143

Triângulo (r. São Bento 1887 - foto Militão - Acervo do Arquivo do Estado, proibida reprodução)- pg. 143

Triângulo (Pç Sé 1862 - Acervo do Arquivo do Estado, proibida reprodução) pg. 144

Triângulo 2000 (foto da autora) - pg. 144

Vila Leopoldina 2001 (foto da autora) - pg. 147 


\section{Resumo:}

As cidades evoluem através da expansão de seu território e de transformações no uso do solo existente. O objetivo deste trabalho é analisar a influência da evolução econômica e da legislação urbana nas transformações do uso do solo residencial na área central do Município de São Paulo entre 1860 e 1999. 


\section{Abstract}

Cities develop through the territorial expansion and transformations in existing urban land use. The objective of this study is to analyze the influence of economic evolution and urban legislation on residential land use transformations in the central area of São Paulo between 1860 and 1999. 


\section{Sumário:}

Lista de tabelas

Lista de figuras

Resumo

"Abstract"

\section{Introdução}

1.1 Objetivos. . . . . . . . . . . . . . . . . . . . . . 1

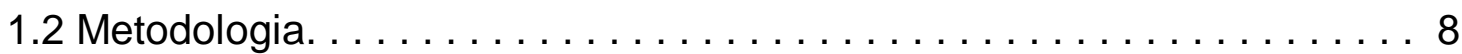

1.3 Bases teóricas e principais levantamentos de uso do solo

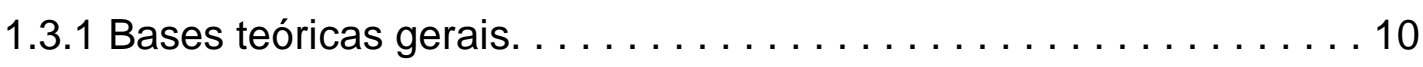

1.3.2 Bases teóricas: Município de São Paulo. . . . . . . . . . . . . . . . 14

1.3.3 Principais levantamentos descritivos de uso do solo no Município de São Paulo. . . . . . . . . . . . . . . . . . . . . . . . . . . . . 29

2. Evolução urbana de São Paulo: uma perspectiva histórica da área estudada

2.1 Período inicial. . . . . . . . . . . . . . . 33

2.2 Período do café. . . . . . . . . . . . . . . . . . . . . . . 44

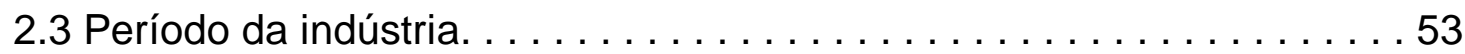

2.4 Período de serviços. . . . . . . . . . . . . . . . . . . 69

3. Legislação restritiva às transformações no uso do solo residencial. .74

\section{Dinâmica das transformações}

4.1 A evolução local - bairros. . . . . . . . . . . . . . . . . . . . . . . 83

4.2 Padrões das transformações. . . . . . . . . . . . . . . . . . . . . .157

\section{Conclusão}

5.1 Transformações do tipo 1, 2 e 3 (aumento de comércio e apartamentos 


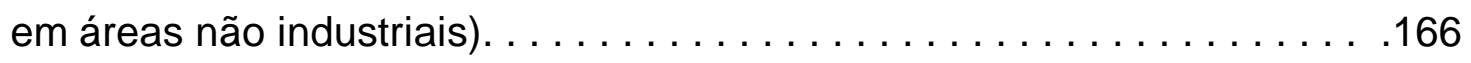

5.2 Transformações do tipo 4 (diminuição do uso industrial). . . . . . . . 179

5.3 Tipo 5 (preservação de alguns bairros residenciais horizontais). . . . 183

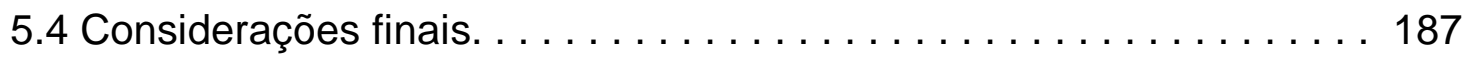

6. Referências Bibliográficas. . . . . . . . . . . . . . . . . . . . . . 190

\section{Anexos}

7.1 Perímetros da legislação. . . . . . . . . . . . . . . . . . . .

7.2 Transparências para sobreposição de mapas. . . . . . . . . . . . 220 


\section{CAPÍTULO 1 - INTRODUÇÃO}

\section{1 - OBJETIVOS}

As cidades se estruturam no meio natural adaptando-o de modo a propiciar um ambiente adequado ao desempenho de determinadas funções dentro das atividades econômicas e sociais humanas.

Resumidamente, podemos afirmar que a partir das necessidades vitais dos seres humanos (alimentar-se, abrigar-se, etc.) surgiram todas as atividades sociais e econômicas. Com a evolução dos procedimentos técnicos através dos quais os homens interagem entre si e no ambiente visando atender às suas necessidades, as estruturas econômicas e sociais, bem como tais necessidades, também foram se tornando cada vez mais complexas ao longo dos séculos. Assim, a humanidade passou de uma vida nômade à utilização de ferramentas, ao desenvolvimento da agricultura e ao assentamento em vilas e cidades; uma das razões que propiciou o nascimento, após a revolução industrial, de novas formas de produção e organização da sociedade até o sistema capitalista e suas variações que conhecemos nos dias atuais. Entretanto, uma das principais características do sistema econômico e social nos últimos dois séculos é a organização de formas de produção especializadas, exigências advindas do livre mercado e da busca do lucro, pilastras básicas desse sistema.

Devido à especialização, espaços urbanos dentro de uma mesma cidade podem ser segmentados, por exemplo, em áreas destinadas 
predominantemente à produção industrial (normalmente em grandes áreas de fácil acesso a insumos e fácil escoamento da produção), áreas predominantemente comerciais e de serviços (localizadas em regiões da cidade que propiciem instalações adequadas e fácil acesso aos compradores e clientes, visando maiores lucros para as atividades instaladas), áreas residenciais (que demandam fácil acesso ao local de trabalho e às atividades sociais, de lazer, comércio e serviços, instalações adequadas ao repouso) etc. Obviamente a existência de tais áreas especializadas não exclui a existência de outras (de uso misto), onde uma ou mais atividades se sobrepõem. Cada um dos setores econômicos e sociais da cidade, tem, portanto, além de seu espaço físico, seus interesses e aspirações individuais ou setoriais, que visam alcançar o lucro e o melhor desempenho de suas funções, que podem ser coincidentes entre si ou conflitantes, surgindo assim a necessidade da criação de instrumentos capazes de organizar e mediar tais conflitos, representados na maioria das vezes pelas atividades de planejamento e regulamentação. Desse modo, podemos afirmar, em linhas gerais, que existem duas forças básicas agindo sobre o ambiente da cidade: a primeira, surgindo desses interesses e aspirações individuais ou setoriais e, a outra, que muitas vezes é chamada de interesse da coletividade, buscando organizar, planejar e regulamentar os interesses diversos e muitas vezes conflitantes.

Como tanto o ambiente natural quanto as atividades econômicas e sociais humanas interagem e evoluem no tempo, os espaços das cidades também evoluem, basicamente de duas maneiras: adaptando novos territórios e conseqüentemente expandindo seu perímetro, ou readaptando áreas já anteriormente adaptadas para novos usos e funções (ZMITROWICZ, W. 1979 
p.50).

No caso de São Paulo, tal processo ocorreu de maneira rápida, e em curto espaço de tempo, o Município evoluiu de uma pequena cidade com reduzida área urbanizada, de importância sócio econômica local, para o centro de uma gigantesca metrópole (REIS FILHO, N. 1994 p.16).

Profundas transformações ocorreram em seu espaço urbano. Áreas da cidade que possuíam como função inicial servir como espaço residencial à elite se transformaram, rapidamente, em pólo atrativo para comércio e serviços (como a Av. Paulista). Outras regiões que outrora serviram como espaço residencial às classes operárias, hoje são utilizadas como espaços residenciais verticalizados destinados à classe média. Outras áreas da cidade deixaram de cumprir suas funções originais e/ou não se readaptaram satisfatoriamente às novas demandas, servindo atualmente a usos muito aquém de suas possibilidades, ao passo que algumas áreas ainda mantém suas funções e características básicas iniciais.

Este trabalho tem como objetivo, portanto, estudar o processo de transformação do espaço urbano residencial (transformando-se ou não em áreas destinadas a outros usos) na área central do Município de São Paulo e suas causas, tendo como enfoque principal da análise, as transformações econômicas e a ação da legislação, tomando como período de estudo, de 1860 até 1999.

Nesse processo de restruturação ou de expansão urbana das cidades visando adaptar o meio físico para o desempenho de novas funções socioeconômicas, significativa soma de recursos é investida tanto pelo poder público como por toda a sociedade. Muitas vezes tal processo ocorre de maneira 
desorganizada, criando espaços novos distantes do núcleo urbano original, exigindo novos investimentos em infra-estrutura e serviços (água, esgoto, energia, iluminação, recolhimento de lixo, escolas, postos de saúde, etc.) ou deixando áreas próximas ao centro, que já dispõe de infra-estrutura, mal utilizadas. Além disso, áreas residenciais que propiciavam boa qualidade de vida para seus moradores podem vir a ter tais características alternadas pela mudança de uso.

São Paulo vem apresentando durante os últimos anos uma tendência menor a expansão de seu território passando a utilizar mais a transformação de uso (ROLNIK, R. 1990 p.37). Portanto, se tal tendência se confirmar, o estudo dos processos de readaptação de antigos espaços irá adquirir grande importância. Durante as duas últimas décadas grandes inovações tecnológicas (principalmente na área de informática e comunicações) e importantes alterações no quadro político mundial (fim da guerra fria, decadência do sistema comunista no leste europeu, etc.) vem transformando radicalmente toda a estrutura socioeconômica mundial (neoliberalismo, flexibilização do trabalho, globalização).

No Município de São Paulo, atualmente a maior e mais importante cidade do país (EMPLASA 1994 p.34), tais reflexos também se fazem sentir. O setor terciário vem adquirindo grande importância dentro da economia da cidade e São Paulo, mesmo com seus grandes problemas, vem adquirindo status de metrópole mundial (EMPLASA 1994 p.43)(SANTOS, M. 1994). Em conseqüência disso, a cidade deverá passar nos próximos anos por profundas alterações em sua estrutura física, que deverá ser significativamente alterada frente às transformações socioeconômicas 
(ROLNIK, R. 1990 p.37). Assim, conhecer como ocorreram tais processos de readaptação dos espaços frente às novas demandas econômicas e sociais, nas décadas imediatamente anteriores, torna-se fundamental tanto para a administração pública como para as forças econômicas e sociais privadas que atuam no espaço da cidade.

Escolhemos trabalhar prioritariamente com áreas residenciais (que se transformaram ou não em outros usos) não somente pela grande extensão, importância e repercussão social que tais áreas no espaço urbano e social das cidades, mas também porque segundo o levantamento bibliográfico preliminar, esse tipo de uso do solo é um dos mais vulneráveis à readaptação.

O levantamento bibliográfico preliminar indicou que a região da cidade que sofreu maior transformação em seu uso do solo foi principalmente aquela de urbanização mais antiga no centro histórico e ampla área ao seu redor. Durante muitos séculos a cidade de São Paulo permaneceu pequena e limitada economicamente. Não havia nesse período uma diferenciação muito nítida no uso do solo. A partir da segunda metade do século XIX, com as riquezas advindas da cultura cafeeira, São Paulo cresceu muito, havendo uma diversificação maior do uso do solo, que foi se consolidando com o tempo. $\mathrm{O}$ estudo deverá abranger, portanto, o período histórico a partir de 1860, quando a cidade começou efetivamente a receber as influências da economia cafeeira. O estudo dos centros urbanos adquiriu nos últimos anos grande importância, principalmente na cidade de São Paulo, pelo valor histórico e simbólico da área, pela grande soma de recursos investida na região e seu importante papel na economia do Município.

Nas últimas décadas as atividades centrais expandiram-se para além dos 
limites do centro histórico inicial, formando uma região próxima ao centro histórico de grande complexidade funcional, o chamado centro expandido. Muitos pesquisadores e diversos órgãos (públicos ou privados) têm necessidade em definir o perímetro do centro. Cada um deles utiliza o critério mais adequado aos seus objetivos. Por exemplo, para efeito do rodízio de veículos, a CET utiliza grandes complexos viários como delimitadores da área do centro expandido, dentro da qual é proibida a circulação de determinados veículos em determinados dias ou horários. A Emplasa utiliza como centro um agrupamento de distritos e subdistritos oficiais (aprovados em lei estadual) de importância para a região metropolitana. A Sempla utiliza agrupamentos de novos distritos aprovados por lei municipal. A Associação Viva o Centro delimitou o centro segundo critérios de homogeneidade (uso do solo, paisagem, etc.), critérios semelhantes aos utilizados por Nice Müller (MÜLLER, N.1958 p. 121).

Ao longo do tempo, os perímetros (e também os critérios para sua delimitação) também variam (MÜLLER, N.1958 p. 121). Assim, se nos séculos XVI ou XVII o centro era o Pátio do Colégio, no início do século XX já abrangia toda a área do Triângulo. Em meados do século XX já extrapolava em muito essa área e, atualmente, segundo alguns perímetros pesquisados, engloba até a região da Av. Paulista, Av. Faria Lima, Av. Luís Carlos Berrini.

Portanto, como este trabalho tem como objetivo estudar o processo de transformação do espaço urbano residencial em outros usos, o perímetro escolhido deveria abranger a área onde efetivamente essa transformação ocorreu com maior intensidade. Comparando-se os mapas de uso do solo em 1955 e 1993, elaborados, respectivamente, por Aroldo de Azevedo 
(AZEVEDO, A. 1958 v.4 s/p) e pelo Plano Metropolitano da Emplasa (EMPLASA $1994 \mathrm{~s} / \mathrm{p}$ ), além dos dados do levantamento bibliográfico preliminar, é possível observar que o perímetro do centro expandido da EMPLASA é o que mais se aproxima da região onde as transformações foram mais intensas, desta forma, esse perímetro foi adotado neste trabalho.

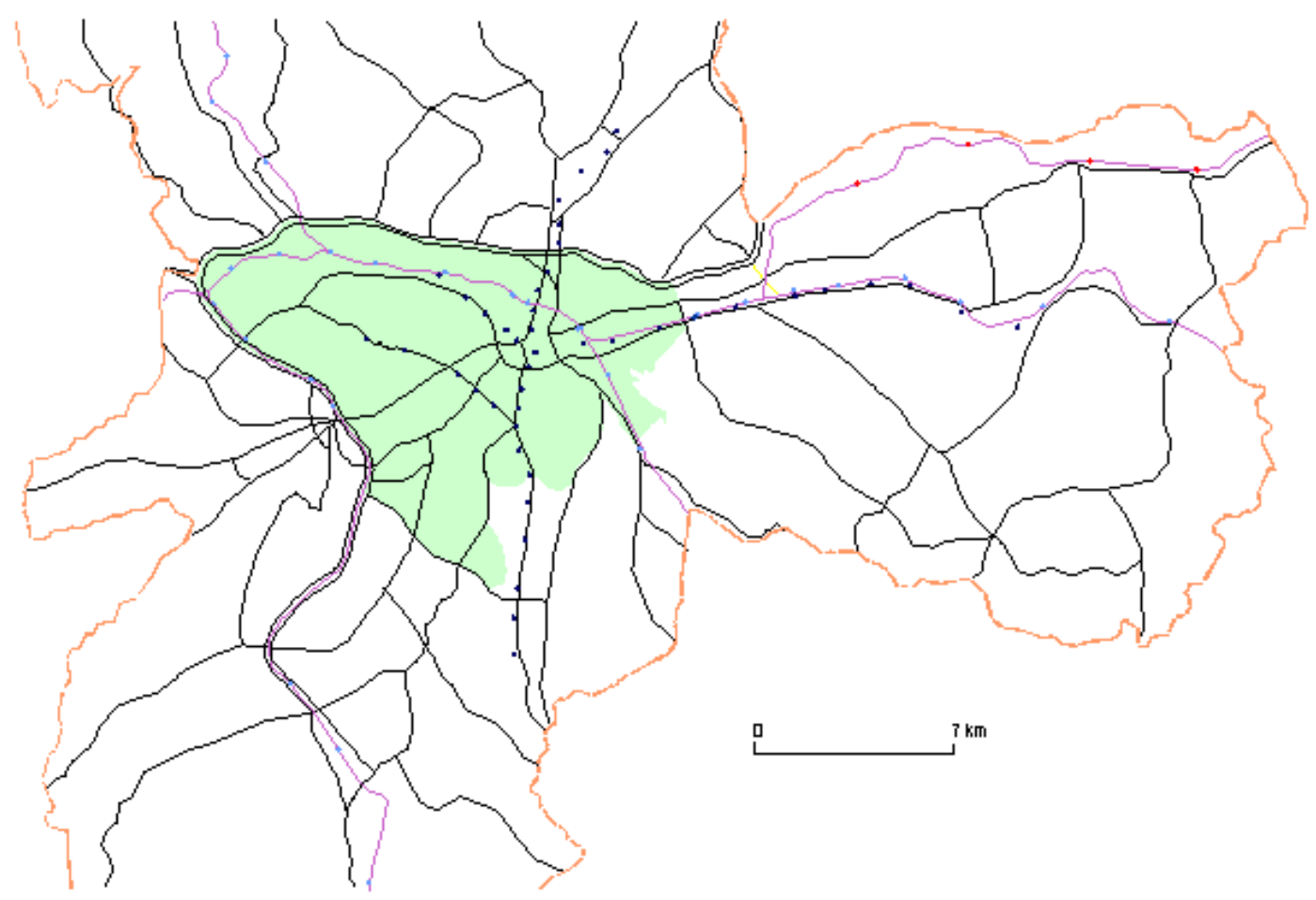

ÁREADE ESTUDO

área de estudo

- vias principais segundo guia Mapograf 1997

- estaçốes de metrô segundo guia M apograf 1997

- estaçốes de trem segundo guia Mapograf 1997 


\section{2 - METODOLOGIA}

Segundo Milton Vargas (VARGAS, M. 1985 p.94) são inúmeros os procedimentos metodológicos possíveis de serem adotados em todos os ramos da pesquisa, cada um deles mais eficiente e adequado à sua área. Este trabalho se baseia na premissa de que para cada fenômeno existe uma ou mais causas e de que é válida a tentativa de elucidá-las (VARGAS, M. 1985 p.105), através de uma análise histórica a partir de bibliografia.

Podemos afirmar que a ocupação do solo ou a transformação de seu uso é coordenada por dois fatores básicos:

- a demanda ou procura pelos espaços, condicionada pelas necessidades de cada setor.

- a oferta ou disponibilidade dos espaços, que poderão ser, mais, ou menos úteis às necessidades.

Desse modo, inspirados em modelos teóricos já há muito tempo conhecidos, também podemos afirmar que cada setor procuraria se instalar no local mais adequado ao melhor desempenho de suas atividades, de acordo com suas possibilidades e conhecimento, ou seja, de sua força na disputa pelos melhores espaços. Essa disputa seria regulamentada por normas e procedimentos visando organizar esses interesses comuns ou conflitantes. Seguindo esta linha de pensamento, o trabalho foi dividido em etapas: 1. Levantamento das transformações gerais no uso do solo do Município de São Paulo no período histórico mencionado, com ênfase nas transformações ocorridas nas áreas residenciais da região escolhida (centro expandido) no período escolhido.

Este levantamento foi elaborado tendo como fonte: 
- bibliografia geral sobre a cidade de São Paulo (história, análises, descrições e viagens, evolução urbana, etc.), que inclui livros, teses e dissertações. - bibliografia sobre ruas, avenidas, bairros ou regiões específicas da cidade incluídas dentro do perímetro da área de estudo.

- documentos produzidos pelos poderes públicos (principalmente Prefeitura do Município de São Paulo e Emplasa), inclusive mapas, dados estatísticos e planos diretores.

Houve uma seleção rigorosa das fontes para que apenas dados confiáveis fossem utilizados. Dados conflitantes foram descartados.

2. Classificação dos dados obtidos por bairros (perímetro no capítulo 4, ítem 4.1) e organização dos mesmos em mapas síntese procurando estabelecer as causas das transformações com ênfase nos aspectos:

- qual a demanda espacial gerada pelas atividades econômicas e classes sociais que pudesse se refletir no uso do solo (principalmente residencial). - qual o papel da legislação nessas mesmas áreas.

- qual o papel da organização do espaço (de um uso sobre outro) sobre as transformações.

3. Análise final dos dados visando estabelecer os padrões das transformações e suas causas. Essa análise foi feita em partes:

A - a verificação da seqüência das substituições de uso, ou seja, o estabelecimento dos padrões das transformações.

B - a classificação do conjunto de causas determinantes de cada padrão de transformação de uso do solo visando estabelecer as probabilidades de que esses fatores sejam os mais relevantes como condicionantes dessas transformações. 


\section{3 - BASES TEÓRICAS E PRINCIPAIS LEVANTAMENTOS DE USO DO SOLO NO MUNICÍPIO DE SÃO PAULO}

\subsection{1 - BASES TEÓRICAS GERAIS}

Diversos estudos foram desenvolvidos com o objetivo de compreender a organização interna das cidades. Segundo Somekh e Villaça há, basicamente, três linhas principais: os modelos espaciais influenciados pela Escola de Chicago (como por exemplo os modelos de Burgess, Hoyt, Harris e Ulmann, etc.), a corrente neoclássica (como Berry, Alonso, Wingo, etc.) e a corrente marxista (como por exemplo Castells, Topalov, Lefebvre, etc.) (SOMEKH, N. 1987 p.73)(VILLAÇA, F. 1998 p.9).

Outros autores, como Vasconcellos e Mccloskey, ligados à teoria econômica, apontam outras correntes, que, sem serem marxistas discordam do pensamento neoclássico, como os intitucionalistas (VASCONCELLOS, M. 1998 p.22)(MCCLOSKEY, D. s/d p.124).

Em 1826 Von Thunen desenvolveu um trabalho sobre a localização da produção agrícola em relação à distância dos centros consumidores em função dos custos de produção e principalmente dos transportes. Com base nesse estudo inicial novos modelos cada vez mais complexos foram desenvolvidos com relação ao espaço urbano, incorporando uma quantidade maior de dados da realidade, como, por exemplo, a não homogeneidade das condições oferecidas por cada localização. Em 1903 Hurd estabeleceu a relação entre a proximidade ao centro e o valor do uso. (SÓCRATES, J. 1983 p.27)(CHORLEY, R. 1971 p.260).

O modelo gráfico de Burguess de 1923 teve grande influência do modelo de localização agrícola de Von Thunen. Segundo esse modelo de Burgess, a 
cidade se desenvolveria em faixas circulares a partir do centro urbano, em um processo pelo qual uma faixa sucederia a outra ao longo do tempo.

Em 1927, Haig, retomando Hurd e Von Thunen, apontou como fatores importantes na estruturação do uso do solo o custo do sítio e dos transportes. Desta forma, as atividades se localizariam no espaço de modo a minimizar os custos de fricção, considerando a friç̧ão os impedimentos à acessibilidade, principalmente ao centro (SÓCRATES, J. 1983 p.28)(ZMITROWICZ, W. 1979 p.VII).

Em 1939, Hoyt, baseado principalmente no estudo de áreas residenciais, desenvolveu o modelo setorial. Segundo ele, o espaço da cidade se desenvolveria em setores e não em círculos concêntricos, pois, para o autor, a direção seria um fator mais importante do que a distância. Outra contribuição importante do autor foi a de evidenciar a importância dos bairros residenciais de alta renda nesse processo (SÓCRATES, J. 1983 p.27, P.42)(ZMITROWICZ, W. 1979 p.VII).

Em 1945 Harris e Ulmann desenvolveram o modelo multicêntrico, que enfatizou a importância de diversos centros com diferentes funções na organização do espaço. Além disso, os autores também demonstraram a importância das funções regionais e históricas da cidade como fatores determinantes de sua organização interna, a relevância das diferentes necessidades locacionais, a atração-repulsão entre os usos, a capacidade de cada setor em concorrer pelo melhor espaço e a própria inércia histórica (ZMITROWICZ, W. 1979 p.53)(CHORLEY, R. 1971 p.269).

No final dos anos 50 e início dos anos 60 surgiram alguns trabalhos de Ratcliff, Wingo e Alonso. Ratcliff, inspirado em Haig, apontou como elemento 
fundamental para a estruturação do uso do solo fatores qualitativos como por exemplo, o desempenho ou eficácia de cada uso em determinado local. Ou seja, para ele, a melhor localização seria ocupada pelo uso mais eficaz (SÓCRATES, J. 1983 p.28)(CHORLEY, R. 1971 p.259).

Alonso, estudando sobretudo áreas residenciais e baseado na teoria dos jogos, deu especial importância à maximização de recursos em função do custo de vida, aluguéis e custo de transporte como fatores determinantes da escolha individual por determinado local (ZMITROWICZ, W. 1979 p.VIII)(CHORLEY, R. 1971 p.260).

Wingo, também estudando áreas residenciais, afirmou que a estruturação do uso do solo seria regida pelas leis de mercado, principalmente a demanda e a oferta. Para o autor, fatores como tamanho dos terrenos, acessibilidade ao centro, custos de transporte e custo de do aluguel determinariam a decisão das famílias pela localização (SÓCRATES, J. 1983 p.31)(CHORLEY, R. 1971 p.260, p. 267).

Outros autores dedicaram-se ao aprofundamento de causas sociais e culturais, como Firey (que apontou a importância da cultura sobre a organização econômica), Berry em 1970 (com o conceito de espaço social, segundo o qual cada indivíduo faria sua escolha dentro de um espaço potencial disponível, determinado por sua posição na sociedade), Form em 1972 (apontando a necessidade de determinação dos agentes econômicos que atuam sobre o espaço), Amato em 1970, (que retomando Hoyt, analisou a importância da localização da elite na organização interna das cidades) e Harvey (sobre a renda obitida através da organização urbana como elemento incentivador das desigualdades sociais (ZMITROWICZ, W. 1979 p.53)(SÓCRATES, J. 1983 
p.65).

Segundo Somekh (SOMEKH, N. 1987 p.74), Topalov concorda com Castells quando afirma que as transformações no uso do solo não são reguladas por leis gerais válidas para todas as cidades universalmente. Para Topalov, o que há são regularidades resultantes do modo de produção no estágio capitalista em que se encontram, aspecto também enfatizado por Lipietz (SOMEKH, N. 1987 p.74). O autor, ainda segundo Somekh, nos mostra também o papel do Estado como elemento estruturador do espaço urbano, agindo de forma diferente de acordo com o estágio do sistema capitalista. Para ele, no estágio monopolista, empresa, mercado e Estado, sem se fundirem, trabalhariam juntos no sentido de beneficiar o capital (SOMEKH, N. 1987 p.76).

Resumidamente, podemos afirmar que as teorias marxistas e neoclássicas diferem em alguns pontos. Para a teoria neoclássica, no sistema capitalista, as leis de mercado, principalmente demanda e oferta comandariam a organização do espaço urbano. Segundo essa teoria, as necessidades humanas são incessantes e os recursos para atende-las são escassos. Cada indivíduo ou cada setor da sociedade realizaria escolhas livres e racionais buscando maximizar a satisfação de suas necessidades e a otimização de seus custos. Haveria, portanto, uma livre competição entre esses agentes pelos recursos escassos, competição essa regulada pelas leis do mercado, principalmente demanda e oferta. A participação do Estado seria neutra, e o sistema, apesar da existência de crises temporárias, tenderia ao equilíbrio, graças à livre escolha e à livre concorrência (GAMES, J. 1952 p.57, p.115)(SMOLKA, M. 1983 p.105, p.130)(VASCONCELLOS, M. 1998 p.18).

Os marxistas analisam as transformações no uso do solo sob o ponto de vista 
da luta de classes. Questionando a legitimidade do direito à propriedade, para eles o sistema capitalista evoluiria em estágios de desenvolvimento que não tenderiam ao equilíbrio, mas à crise, que levaria a novo estágio. Para os marxistas, a discussão da questão do poder na sociedade é mais relevante do que as leis do mercado. Para marxistas e institucionalistas as escolhas e o mercado não seriam livres, bem como o Estado não seria um mediador neutro (VASCONCELLOS, M. 1998 p.22)(SMOLKA, M. 1983 p.139)(MCCLOSKEY, D. s/d p.122).

\subsection{2 - BASES TEÓRICAS: MUNICÍPIO DE SÃO PAULO}

Inúmeros pesquisadores se dedicaram a análise da estrutura do uso do solo na cidade de São Paulo. Segundo Sócrates (SÓCRATES, J. 1983, p.24), os trabalhos mais importantes desenvolvidos até a década de 80 foram os de Morse (MORSE, R. 1954) e, sobretudo, Langenbuch (LANGENBUCH, J. 1971) e Villaça (VILLAÇA, F. 1978). Langenbuch realizou extensa análise da Grande São Paulo e Villaça sobre as metrópoles do sul do Brasil, com um enfoque maior sobre as transformações de uso do solo residencial e comercial. Sobre legislação dois trabalhos importantes são os de Andrade (ANDRADE, F. 1966) e Zmitrowicz (ZMITROWICZ, W. 1979). O trabalho de Andrade discute a influência da legislação na estruturação das cidades, enquanto o de Zmitrowicz dá especial atenção ao zoneamento, discutindo sua implantação. Na década de 90 podemos citar os trabalhos de Rolnik (ROLNIK, R. 1997) e Feldman (FELDMAN, S. 1996).

Sobre as transformações no uso do solo também podemos citar os trabalhos de Somekh (SOMEKH, N. 1989) (SOMEKH, N. 1994) sobre a verticalização, sobretudo verticalização residencial e os trabalho de Bruna (BRUNA, G. 1984) 
e Vargas (VARGAS, H. 1993) sobre uso comercial.

Sobre o centro histórico temos os trabalhos de Cordeiro (CORDEIRO, H. 1980)e Lefevre (LEFEVRE, J. 1985), a primeira realizou uma análise mais funcional e o último sobre o papel dos transportes como fator condicionante das transformações da área. Cordeiro (CORDEIRO, H. 1993) também elaborou uma análise sobre o centro expandido e suas transformações mais recentes. Outro trabalho, também importante para esta dissertação, foi o de Villaça (VILLAÇA, F. 1998), que fez uma comparação entre as metrópoles brasileiras levantando importantes fatores condicionantes das transformações no uso do solo.

No caso de São Paulo diversas hipóteses foram levantadas para explicar a organização do uso do solo, tanto no caso da instalação de usos novos como nas transformações de usos já consolidados.

A hipótese de que a demanda gerada pelas atividades socioeconômicas é um fator condicionante das transformações urbanas é uma tese há muito reconhecida, como afirmam Zmitrowicz, Meyer e Souza, esta última se referindo a Milton Santos.

"A cidade é formada por uma superposição de estruturas sucessivas, criadas através da readaptação dos elementos existentes ou da implantação de elementos novos. As transformações físicas são reflexo das transformações econômicas e sociais que ocorrem no sistema urbano-rural (ZMITROWICZ, W. 1979 p.50)

“É conhecida a tese segundo a qual as mudanças nas esferas econômicoprodutiva e tecnológica estão sempre associadas a transformações na esfera urbana.” (MEYER, R. 2000 p.5) 
"Desnecessário insistir que há uma relação espaço-sociedade”(SOUZA, M. 1994 p.24)

Um exemplo da ação da demanda sobre o desenvolvimento urbano é o fato de que os bairros populares e de classe média cresceram rapidamente. Outros bairros, com demanda menor, como os bairros de elite cresceram lentamente (MENDES, R. 1958 p.233, p.313, p.323, p.341, p.357).

A questão da acessibilidade e consequentemente dos transportes também aparece como uma hipótese importante. Segundo essa hipótese, áreas com boa acessibilidade teriam maior tendência tanto a serem ocupadas rapidamente como a sofrerem transformações mais intensas, atraindo, sobretudo, a verticalização e o comércio/serviços.

Obviamente essa "boa acessibilidade" é relativa aos interesses dos diversos setores da sociedade. Assim, por exemplo, áreas bem servidas pelas ferrovias e posteriormente rodovias foram interessantes para o uso industrial e para 0 uso residencial operário (MENDES, R. 1958 p.233, p.356)(TARALLI, C. 1993 p.158)(SEGATTO, J. 1988 p.32)(BRUNO, E. 1954 p.1026).

Áreas residenciais bem servidas por linhas de bondes e ônibus tiveram rápido desenvolvimento (MENDES, R. 1958 p.287, p.307)(TARALLI, C. 1993

p.71)(REALE, E. 1982 p.72, p.137)(PACHECO, J. 1982 p.139)(PETRONE, P. 1963 p.123).

As vias de maior fluxo de veículos e pessoas foram apontadas como aquelas onde o uso comércio e serviços se desenvolveria primeiro, com maior rapidez e intensidade (PETRONE, P. 1963 p.127)(DERTÔNIO, H. 1971 p.78)(BACELLI, R. 1982 p.82)(CORDEIRO, H. 1980 p.74, p.77). Pontos de concentração do fluxo de transportes coletivos, como pontos e 
terminais de ônibus, estações ferroviárias, etc. também foram apontados como locais onde se desenvolveu o uso comércio e serviços (SOMEKH, N. 1989 p.83)(MENDES, R. 1958 p.241, p.264, p.290, p.295)(PETRONE, P. 1963 p.126, p.135, p.137). Alguns autores nos mostram que subcentros de comércio e serviços importantes como o Brás, Lapa, Pinheiros e Itaim surgiram em pontos estratégicos sob o ponto de vista da acessibilidade e dos transportes coletivos (VILLAÇA, F. 1978 p.121)(MENDES, R. 1958 p.284 E p.317)(LOPES, H. 1988 p.65)(REALE, E. 1982 p.63)(SEGATTO, J. 1988 p.59)(OSELLO, M. 1983 p.164)(SANTOS, W. 1980 p.76).

A ausência, ou deficiência no transporte coletivo foi apontada como causa inibidora da ocupação, desenvolvimento ou transformação do uso solo em alguns locais, como diminuição do comércio, ausência de verticalização ou baixa ocupação (MENDES, R. 1958 p.196, p.349)(TARALLI, C. 1993 p.79)(DOREA, A. 1982 p.110). O acesso difícil ao centro histórico para o automóvel e para carga e descarga de mercadoria foi citado por Cordeiro como um dos fatores que contribuíram para o esvaziamento da região e o surgimento de novas áreas comerciais e de serviços (CORDEIRO, H. 1980 p.88, p. 107).

A verticalização residencial também seria condicionada pela acessibilidade. A deficiência de qualidade do transporte coletivo, em uma época em que o automóvel não era um meio de locomoção acessível à classe média, foi apontado por Somekh como um dos fatores que condicionou a instalação do uso residencial vertical nos bairros próximos ao centro histórico, local de compras e empregos dessa classe (SOMEKH, N. 1989 p.69). Cordeiro também aponta essa deficiência como um fator a favorecer a concentração de comércio 
e serviços no centro histórico, a região melhor servida por transportes coletivos nesse mesmo período (CORDEIRO, H. 1980 p.152).

Com o aumento da utilização do automóvel houve maior flexibilidade de acesso, não havendo necessidade de um único centro, como veremos adiante (VILLAÇA, F. 1978 p.292).

A instalação ou melhora no transporte coletivo, bem como a abertura de novas vias e outras obras viárias favorecendo o acesso, condicionaram maior ocupação de alguns bairros e o desenvolvimento da verticalização e do comércio e serviços (TARALLI, C. 1993 p.90, p.118, p.200, p.231)(SOMEKH, N. 1989 p.63, p.68) (ICI V.1 1992 p.9) (MENDES, R. 1958 p.265)(MÜLLER, N. 1958 p.143) (SEGATTO, J. 1988 p.43) (SANTOS, W. 1980 p.115)(DERTÔNIO, H. 1971 p.13). Por outro lado, obras viárias também podem alterar o fluxo de pessoas, prejudicando a acessibilidade (MARZOLA, N. 1979 p.110) e também prejudicando a qualidade de vida, como afirmaram Cordeiro e Taralli sobre o elevado Costa e Silva (TARALLI, C. 1993 p.204)(CORDEIRO, H. 1980 p.75, p.90).

O valor de terrenos e imóveis para compra/venda ou aluguel também foi uma hipótese citada por alguns autores. Dessa forma, baixo custo de terrenos e de aluguéis atrairia principalmente usos industrial e residencial popular (MENDES, R. 1958 p.233). Já o custo elevado provocaria, por exemplo, a verticalização, pois o alto valor obrigaria o empreendedor a diluir os custos com uma área vertical maior (SOUZA, M. 1994 p.170) (MENDES, R.1958 p.280, p.288, p.343, p.360)(TARALLI, C. 1993 p.231)(SOMEKH, N, 1989 p.80, p.84)(MÜLLER, N. 1958 p.151, p.178).

A valorização também provocaria uma maior disputa por alguns locais e um 
afastamento dos usos residenciais, industriais e do pequeno comércio, pois somente atividades geradoras de um lucro maior por área construída seriam capazes de pagar os altos valores cobrados. $O$ valor alto também incentivaria os proprietários a vender seus imóveis e aplicar o lucro em outros empreendimentos (SINGER, P. 1968 p.74)(VILLAÇA, F. 1978 p.341)(MÜLLER, N. 1958 p.125, p.161)(MENDES, R. 1958 p.275).

Inúmeros autores também citaram a atração e repulsão entre usos como um fator condicionante de grande importância, como Zmitrowicz (ZMITROWICZ, W. 1979 p.53). Segundo essa hipótese, alguns usos teriam a capacidade de afastar, ou repelir outros, como o uso comercial, que provocaria o afastamento do uso residencial (ICI V. 121995 p. 19, p.21)(ICI V.12 1995 p.12)(MÜLLER, N. 1958 p.130, p.132)(HOMEM, M. 1980 p.154, p.164)(TORRES, M. 1981 p.218)(VILLAÇA, F. 1998 p.227). O uso industrial poderia afastar o uso residencial, principalmente de elite e classe média pela deterioração da qualidade ambiental (ICI V. 121995 p.9)(TORRES, M. 1981 p.218).(JORGE, C. 1988 p.114).

Ainda segundo essa hipótese, alguns usos atrairiam outros, tanto no caso da instalação de novos usos como no caso da transformação de um tipo de uso em outro. Desta forma, além de vias ou meios de transporte e seus pontos de parada outros elementos foram citados como responsáveis pelo nascimento ou desenvolvimento de muitos bairros paulistanos, como igrejas (JORGE, C. S/D p.71)(TORRES, M. 1981 p.43)(TORRES, M. 1977 p.12), parques e jardins (VILLAÇA, F. 1978 p.175, p. 179)(GUIMARÃES, L. 1977 p.39, p.58)(DOREA, A. 1982 p.41), matadouro (TORRES, M. 1977 p.63)(MASAROLO, p. 1971 p.43), e até mesmo aeroporto (MENDES, R. 1958 p.288), estádio (MENDES, 
R. 1958 p.341), estação de rádio (MENDES, R. 1958 p.343), hospital e escola de medicina (MENDES, R. 1958 p.282, p.284).

Estações ferroviárias, lojas e shoppings pioneiros foram apontados como um dos fatores responsáveis pelo nascimento ou ampliação de áreas comerciais importantes, como por exemplo o Mappin para a Cidade Nova, o Conjunto Nacional para a avenida Paulista, o Shopping Iguatemi para a avenida Faria Lima, a loja Franita para o Itaim. (TOLEDO, B. 1981 p.86)(CORDEIRO, H. 1980 p.79, p.91, p.95)(SOMEKH, N. 1989 p.63)(LOPES, H. 1988 p.69). Bancos foram atraídos para o Triângulo para imediações do Banco do Brasil, escritórios de advocacia pelo fórum, repartições públicas atrairiam mais repartições públicas (MÜLLER, N. 1958 p.166, p.174)(MENDES, R. 1958 p.174)(TORRES, M. 1981 p.219).

Portanto, segundo essa hipótese, alguns usos atrairiam outros, como por exemplo, comércio atrairia comércio, expandindo sua área sobre bairros vizinhos (MÜLLER, N. 1958 p.175)(HOMEM, M. 1980 p.154), o uso industrial atrairia o residencial operário pela oferta de empregos (LOPES, H. 1988 p.12). O uso residencial de elite atrairia para sua proximidades tanto os novos usos residenciais de classe alta e média como também o uso residencial vertical, o comércio e serviços e até mesmo a administração pública (VILLAÇA, F. 1978 p.179, p. 195, p.206, p.296)(VILLAÇA, F. 1998 p.34, p.274, p.319)(MACEDO, S. 1987 p.40)(BACELLI, R. 1982 p.82)(ROLNIK, R. 1997 p.112)(HOMEM, M. 1980 p.150)(CORDEIRO, H. 1980 p.146, p.147).

Flávio Villaça dá especial atenção ao papel dos bairros de elite como elementos estruturadores do espaço intra-urbano, principalmente relacionada a acessibilidade ao centro. Realizando um estudo histórico e comparativo 
entre diversas hipóteses e que envolveu as principais metrópoles brasileiras, Villaça conclui que a segregação das elites, para ele uma forma de dominação, seria o elemento fundamental. Para o autor, o espaço intra-urbano é estruturado (o autor dá grande enfoque a estrutura) em torno das condições de consumo, ou seja, pelo controle do tempo de deslocamento dos consumidores (diferentemente do que ocorre no espaço regional, estruturado, segundo ele pelo "controle do tempo de deslocamento das mercadorias e capitais'). Desta forma, as classes sociais disputariam as localizações. A segregação espacial nasceria, segundo o autor, como uma forma de dominação, ou de "apropriação diferenciada das vantagens do espaço". Para ele, essa dominação se daria pelo controle do mercado imobiliário, do Estado (principalmente infra-estrutura e legislação) e da ideologia. As classes menos favorecidas ficariam com as áreas menos disputadas (VILLAÇA, F. 1998 p.232). Afirma o autor:

"O espaço urbano é produzido e consumido por um mesmo e único processo. A sua estruturação interna, entretanto, se processa sob o domínio de forças que representam os interesses de consumo (condições de vida) das camadas de mais alta renda. Como mostra este trabalho, tal estruturação se dá sob ação do conflito de classes em torno das vantagens e desvantagens do espaço urbano, ou, como já foi dito, e parafraseando Castells, em torno da disputa pela apropriação diferenciada do espaço urbano enquanto produto do trabalho.

Entende-se por dominação por meio do espaço urbano o processo segundo o qual a classe dominante comanda a apropriação diferenciada dos frutos, das vantagens e dos recursos do espaço urbano. Dentre essas vantagens, a mais 
decisiva é a otimização dos gastos de tempo despendido nos deslocamentos dos seres humanos, ou seja, a acessibilidade às diversas localizações urbanas, especialmente ao centro urbano. E é essa a questão essencial revelada por todas as transformações da estrutura urbana mostradas nos casos empíricos anteriormente expostos. O benefício ou recurso fundamental que se disputa no espaço urbano é o tempo de deslocamento. As burguesias produzem para si um espaço urbano tal que otimiza suas condições de deslocamento. Ao faze-lo, tornam piores as condições de deslocamento das demais classes."...(VILLAÇA, F. 1998 p.328) "Em que condição os indivíduos entram naquela disputa? Eles o fazem enquanto classes sociais lutando pelas condições materiais de sua sobrevivência, embora tais condições sejam definidas na esfera da produção. As classes sociais disputam aquele domínio e as burguesias são as classes que mais conseguem exerce-lo. Como afirma Harvey (1993, 212), "o domínio do espaço sempre foi um aspecto vital da luta de classes". Assim, a luta de classes pelo domínio das condições de deslocamento espacial consiste na força determinante da estruturação do espaço intra-urbano. Nem sempre as burguesias procuram o "perto" em termos de tempo e distância. Às vezes elas se afastam na busca de grandes lotes e ar puro, por exemplo, mas mesmo quando isso ocorre há limites para esse afastamento. Nesses casos elas procuram trazer para perto de si seu comércio, seus serviços e o centro que reúne os equipamentos de comando da sociedade - e isso não por razões simbólicas ou de status mas pela razão muito prática de que elas o freqüentam intensamente e nele exercem muitos de seus empregos. Revolucionam o centro principal, produzem "centros expandidos", o "seu" centro e o centro dos 
outros. A pulverização dos novos centros metropolitanos, observada em metrópoles como Salvador e São Paulo, nada mais é do que a manifestação de expedientes das camadas de mais alta renda para trazer para mais próximo delas (no que se refere ao tempo) os equipamentos de controle da sociedade, seus empregos e seus serviços e ao mesmo tempo produzir centros mais adaptados a seu meio predominante de locomoção: o automóvel. Esse novo espaço poderia resultar da remodelação do antigo, como já ocorreu no passado. A nova mobilidade territorial, todavia, permite e requer um centro totalmente novo. Disso se aproveitam os interesses imobiliários na sua constante tentativa de encurtar a vida dos produtos imobiliários. Surgem daí os centros novos espacialmente atomizados". (VILLAÇA, F. 1998 p.329) Sócrates também chegou à conclusões semelhantes. Partindo da análise dos principais modelos de estruturação do uso do solo a autora identificou alguns pontos comuns entre eles, como o fato da cidade ser considerada uma unidade com setores cada vez mais especializados, o papel polarizador do centro (e consequentemente da acessibilidade a ele) e a existência de competição entre os vários setores. Ao analisar o uso do solo no Município de São Paulo, entretanto, a autora encontrou uma situação diferente, com forte tendência aos usos mistos, complementares entre si, onde os bairros residenciais de elite teriam papel predominante como elementos estruturadores e onde a competição seria controlada com "atuação deliberada de determinados setores". Afirma a autora:

"Assim, ao conceito de cidade como unidade se acrescenta o de que a cidade não é uma unidade; ao conceito de centro se acrescenta o de centralidade; ao de primazia do comércio se acrescenta a do uso residencial de altos padrões 
conjugado com parcelas selecionadas de outros usos; ao de especialização se acrescenta o de especialização seletiva; à competição pelo uso do solo se acrescenta o conceito de reserva de área"(SOCRATES, J. 1983 p.194) Para Cordeiro as classes de alta renda teriam uma capacidade maior de influenciar o desenvolvimento urbano pelo controle dos investimentos públicos (CORDEIRO, H. 1980 p.100).

Ao estudar a verticalização Souza se preocupou em identificar, além das causas, os agentes envolvidos no processo. Partindo de uma análise histórica que dá especial destaque à verticalização como fenômeno da metropolização, a autora analisa, além do papel dos agentes, principalmente a atuação do Estado e do mercado (principalmente através da valorização). Desta forma, a autora identifica como principais agentes da verticalização os compradores (ou consumidores), os produtores (ou construtores) e os incorporadores (que controlam o processo, segundo a autora, desde a compra do terreno até a comercialização do apartamento)(SOUZA, M. 1994 p.192). Para Souza há uma aliança entre esses setores e o Estado, que se dá pela liberação de financiamentos, colocação de infra-estrutura e melhoria do acesso (SOUZA, M. 1994 p.132 e p.239) e a legislação, que se adaptaria aos interesses desses setores (SOUZA, M. 1994 p.238). Afirma a autora: "No Brasil, especialmente em São Paulo, a explosão da verticalização se dá a partir de 1964, com a criação do BNH."...."O Estado brasileiro, portanto, através de um banco público, é que vai financiar esse processo, pelas razões anteriormente expostas: a longevidade do período de produção e de circulação da mercadoria-habitação. Por outro lado, no que concerne à propriedade fundiária e ao seu uso pela verticalização, será objeto de múltiplas alianças 
entre os donos da terra e os incorporadores, manifestas por uma intermediação do Estado que, em última análise, não só libera o solo para a verticalização (lei de zoneamento e uso do solo) como promove a sua valorização através da implementação das políticas públicas (infra-estrutura, saneamento, comunicação, transporte, etc. etc.). Apesar, pois, das reclamações, o Estado brasileiro tem sido um forte aliado da incorporação imobiliária. Os altos e baixos desse setor se deve muito mais à complexidade da evolução das economias do Terceiro Mundo do que uma atuação definitiva e permanente do Estado nesse setor.

Ressalte-se, ainda, que esse financiamento se fez com a criação do Fundo de Garantia por Tempo de Serviço (FGTS), que foi a forma de captar recursos, especialmente da classe trabalhadora para gerar bens que, repassados mediante financiamentos e a longo prazo à classe média, tornou-a o grande aliado do Estado e da incorporação, viabilizando decisivamente esse processo pelo menos por cerca de vinte e cinco anos.

Portanto, ainda que se argumente não haver relação direta entre incorporação e Estado, ela é estreitamente realizada através das possibilidades criadas por ele, e somente por ele, de aquisição dos produtos da incorporação - os apartamentos, que realizam o ideal de casa própria de milhões de brasileiros, impulsionando, assim, incorporação e verticalização."(SOUZA, M. 1994 p.196) Para Somekh a valorização é um elemento importante a condicionar a verticalização, entretanto a autora nos alerta par o fato de que não somente áreas valorizadas se verticalizam, pois muitas vezes terrenos de custo menor podem significar lucros maiores (SOMEKH, N. 1989 p.85 e p.153). Somekh também aponta a possibilidade de financiamento como elemento 
condicionador da verticalização (SOMEKH, N. 1989 p.163).

Além de Souza, outros autores como Meyer (MEYER, R. 2000 p.5) e Singer (SINGER, P. 1968 p.76) nos alertam para o fato de que as transformações na região central somente podem ser abordadas dentro de uma análise que inclua o papel do centro dentro da metrópole. Singer, por exemplo, afirma que sómente a metrópole pode manter determinados serviços altamente especializados. O autor transcreve Blumenfeld:

"Ainda mais importante é a disponibilidade de uma variedade de bens e serviços dos quais qualquer empresa de negócios depende. Só uma metrópole pode manter os grandes estoques, meios de transporte e serviços especializados - particularmente os de natureza fianceira, legal, técnica e promocional - que são essenciais à empresa moderna. Tais serviços constituem a principal fonte de força econômica da metrópole - sua verdadeira base econômica. Eles são especialmente importantes para empresas pequenas, novas e experimentais. A metrópole, em particular sua área central, serve, portanto, de incubadora para tais empresas..." (BLUMENFELD, J. "THE MODERN METROPOLIS IN SCIENTIFIC AMERICAN SETEMBRO DE 1965, V. 213, N. 3 p. 68 in SINGER, P. 1968 p.76) Sobre a legislação, Reale e Homem acrescentam que ela poderia ser um dos fatores responsáveis pelo desenvolvimento do comércio em bairros próximos àqueles onde tal atividade era proibida através do deslocamento da demanda (REALE, E p.138 e p.145)(HOMEM, M. 1980 p.158). Para Wakisaka a legislação, mais precisamente, o zoneamento não tem a capacidade de induzir a novos usos, apenas, em alguns casos ela não permite a transformação (WAKISAKA, T. 1991 p.219). 
Alguns autores associam importantes transformações no uso do solo ao esgotamento das possibilidades atrativas de um local e à concorrência de outros lugares com melhores condições. Mendes, por exemplo, aponta como um dos fatores para a saída das elites de Campos Elíseos à concorrência com a avenida Paulista e Higienópolis (MENDES, R. 1958 p.202 e p.299). Lopes afirma que o esgotamento de outras áreas com iguais condições teria sido um dos fatores que condicionou a verticalização no Itaim (LOPES, H. 1988 p.68). Relacionando o esgotamento com a acessibilidade, sobre as alterações no centro histórico, afirma Lefevre:

“A concentração de atividades e serviços na área central da cidade se manteve enquanto a sua acessibilidade se manteve para a população de maior mobilidade. Quando o número de veículos em circulação aumentou em proporção extremamente rápida, principalmente a partir da segunda metade da década de 1950, o acesso ao centro se tornou cada vez mais difícil. Isto conduziu ao desdobramento, em primeiro lugar, de diversas atividades comerciais para áreas mais acessíveis à população de alto poder aquisitivo, como o aparecimento das filiais de lojas em bairro ou ao completo deslocamento de diversos estabelecimentos." (LEFEVRE, J. 1985 p.68) Cordeiro afirma:

"O desdobramento do Centro Metropolitano se reflete como uma evidência da ação dos agentes econômicos que buscam maior eficiência através de economias de aglomeração. Ao mesmo tempo, seu poder de atração aumenta pela falta de investimentos em infra-estrutura e equipamentos em outras áreas, que poderiam suportar o atendimento da demanda da instalação de serviços de padrão metropolitano. Num círculo vicioso, somam-se ai, entre outros, os 
problemas da inexistência de edifícios para receber serviços de alto padrão; o mau funcionamento da infra-estrutura de todas as ordens, sobretudo o das comunicações telefônicas, exigindo a presença do interessado no centro e consequentemente o aumento do número de viagens para a área; a falta de espaço para estacionamento; o congestionamento crônico de trânsito causado pelo aumento de número de veículos e pedestres e pela forma estelar do circuito de artérias no seu interior e todo um corolário de consequências, entre as quais a própria população ambiental crescente do nosso sistema de vias. Esta situação atinge o freqüentador do Centro, para o qual o carro representa além do status e conforto, a liberdade de trajeto e de tempo e portanto de rendimento do trabalho urbano. Por todos esses fatores, nos anos sessenta, a economia de escala, que é uma curva de crescimento contínuo, deve ter atingido o ponto de inflexão em que o adensamento produz deseconomias, provocando a procura de novos espaços" (CORDEIRO, H. 1980 p.59) Lefevre, Jorge e Müller também associam a maior facilidade de estacionamento ao surgimento de novos subcentros (LEFEVRE, J. 1985 p.75)(MÜLLER, N. 1958 p.166)(JORGE, C. S/D p.177). A existência de infraestrutura também foi citada por Rolnik e Taralli como elemento condicionante de transformações (ROLNIK, R. 1997 p.130)(TARALLI, C. 1993 p.90). O desenvolvimento da técnica também foi citado por alguns autores. Em um primeiro período histórico era inadmissível para a maioria dos membros da elite paulistana residir, por exemplo, próximo às várzeas, devido a sua insalubridade e desconforto (doenças, insetos, enchentes). O desenvolvimento da técnica (tanto no campo da saúde como no campo da engenharia) fez com que determinadas áreas pudessem ser adaptadas. Assim, por exemplo, foi 
possível a implantação de áreas residenciais de classe média e até de elite próximas ao rio Pinheiros (REALE, E. 1983 p.211) ou a verticalização da avenida Leopoldo Couto de Magalhães no Itaim (LOPES, H. 1988 p.74). A evolução dos meios de transporte, do transporte das tropas, as ferrovias, os bondes, ônibus, o metrô, bem como a evolução dos métodos construtivos dos edifícios, pontes e viadutos são alguns dos inúmeros exemplos que podem ser citados (HOMEM, M. 1980 P.150).

Outros fatores também foram mencionados como responsáveis por transformações no uso do solo, como por exemplo, fatores culturais, como o fim do preconceito por parte da classe média por apartamentos (SOUZA, M. 1994 p.71), a prostituição no Bom Retiro expulsando usos residenciais (DERTÔNIO, H. 1971 p.69), o fator status de um bairro aumentando sua atratibilidade (MACEDO, S. 1987 p.72)(HOMEM, M. 1980 p.143)(REALE, E. 1982 p.131), o aumento da demanda por comércio e serviços provocados por mudanças nos padrões de consumo (VILLAÇA, F 1998 p.283)(SOMEKH, N. 1989 p.127) e do papel da mulher na sociedade (VILLAÇA, F. 1998 p.175)(VILLAÇA, F. 1978 p.248)(JORGE, C. S/D p.169), a decadência material de edifícios, dificuldades de administração de heranças e o tamanho de terrenos teriam colaborado com a verticalização (TARALLI, C. 1993 p.128)(SOMEKH, N. 1989 p.81)(CORDEIRO, H. 1980 p.99, p.107)(HOMEM, M. 1980 p.150, p.163)(MENDES, R. 1958 p. 305).

\subsection{3 - PRINCIPAIS LEVANTAMENTOS DESCRITIVOS DO USO DO SOLO NO MUNICÍPIO DE SÃO PAULO}

No caso da cidade de São Paulo foram feitos inúmeros levantamentos descritivos sobre o uso do solo, alguns parciais (como a série sobre a história 
de bairros produzidos pelo Departamento de Patrimônio Histórico do Município de São Paulo desde a década de sessenta, os levantamentos produzidos pelo Instituto Cultural Itaú, os levantamentos realizados pela Associação Viva o Centro, normalmente publicados na revista Urbs e teses e dissertações produzidas pela Universidade de São Paulo e outras universidades) e outros, que descreveremos a seguir, de caráter global (envolvendo toda a cidade), pontuais (referentes apenas a um determinado ano) ou históricos.

Na década de 50 foi elaborado um levantamento descritivo do uso do solo em todo o Município e parte da Grande São Paulo por um conjunto de pesquisadores coordenados por Aroldo de Azevedo. Esse trabalho, além de descrever a situação do uso do solo à época também fez uma retrospectiva histórica (AZEVEDO, A. 1958).

Na década seguinte, através do PUB (Plano Urbanístico Básico) também foi feito um levantamento detalhado. Na década de 70, como parte dos trabalhos para a elaboração da legislação de zoneamento também foram realizados alguns trabalhos, o mais notável deles a consolidação dos dados estatísticos de uso do solo obtidos junto ao cadastro da cobrança do imposto predial e territorial (IPTU) pela Prefeitura, que ficaria conhecido como TPCL (Territorial, Predial, Conservação e Limpeza). Esse trabalho, apesar de suas falhas, como a não inclusão de áreas irregulares e o fato de ser um banco de dados numéricos, representou um grande avanço, pois nos permite visualizar o uso do solo no início da década de 70 quadra a quadra (CESADFAUUSP/PMSP/TPCL 1971) (SÃO PAULO (PMSP) 1969). Na década de 80, além dos dados do TPCL foi realizado um levantamento para elaboração do Plano Diretor na gestão de Mário Covas na Prefeitura 
(SÃO PAULO (PMSP) 1985). Na década de 90, além da existência de novos dados do TPCL foi realizado novo levantamento para a elaboração do Plano Diretor da gestão da prefeita Luiza Erundina (SÃO PAULO (PMSP) 1990). A EMPLASA também elaborou um mapa de uso do solo para 1993, como parte integrante do Plano Metropolitano (EMPLASA $1994 \mathrm{~s} / \mathrm{p}$ ).

Em 2000 a Prefeitura do Município de São Paulo através de técnicas de geoprocessamento elaborou novo mapa de uso do solo para $1999 \mathrm{com}$ utilização dos dados do TPCL e um levantamento detalhado com dados obtidos da RAIS, produzindo documento sobre as transformações no uso do solo na última década (SÃO PAULO (PMSP/SEMPLA 2000). Quanto ao valor do solo, o primeiro levantamento realizado foi em 1938 por Britto (BRITTO, R. s/d). A partir da década de 60 é possível contar com os dados do valor venal dos imóveis, processado pela Secretaria de Finanças da Prefeitura do Município e publicados pela Imprensa Oficial do Estado. Tais dados foram agregados em setores e mapeados no trabalho realizado por Maria Adélia de Souza (SOUZA, M. 1994). 


\section{CAPÍTULO 2 - EVOLUÇÃO URBANA DE SÃO PAULO: UMA PERSPECTIVA HISTÓRICA DA ÁREA ESTUDADA}

Este capítulo procura mostrar como foi a evolução urbana de São Paulo. Foi dividido em quatro períodos históricos. Esta divisão teve como critérios fatores econômicos.

2.1 - PERÍODO INICIAL - Mostra, de forma resumida como se formou a cidade de São Paulo. Inclui os períodos da fundação, bandeirismo, o período dos tropeiros e da fundação da Academia de Direito, quando a cidade era ainda pequena e com pouca diferenciação no uso do solo.

2.2 - PERÍODO DO CAFÉ - Inclui o período do café até o final do século XIX, quando do surgimento da indústria.

2.3- PERÍODO DA INDÚSTRIA - do final do século XIX até a década de 80 do século $\mathrm{XX}$, abrange o período do nascimento e desenvolvimento da indústria 2.4 - PERÍODO DE SERVIÇOS - décadas de 80 e 90, quando a função industrial entre em declínio em relação ao setor de serviços. 


\section{1 - PERÍODO INICIAL}

São Paulo foi fundada oficialmente em 1554 com a construção de um colégio destinado à catequização dos indígenas pelos jesuítas (PORTO, A.1992 p.9), que pretendiam assim expandir o domínio da Igreja pelo sertão (SÃO PAULO (PMSP/SERA) 1992 p.12).

O sítio, "uma encruzilhada de vias naturais"(MATTOS, D. 1958 p.15), e que já representava um ponto centralizador para os indígenas foi escolhido de forma estratégica, de modo a assegurar tanto a acessibilidade quanto a defesa, garantidas pelas condições específicas do relevo e da hidrografia (SÃO PAULO (PMSP/SERA) 1992 p.12)(ZMITROWICZ, W. 1986 p.1).

No mesmo período histórico, outros núcleos foram fundados, entretanto, devido ao poder dos jesuítas e a sua posição geográfica, logo São Paulo se tornou o núcleo mais importante de sua região (SÃO PAULO (PMSP/SERA) 1992 p.13).

Partindo do pequeno colégio e igualmente condicionados pelo relevo e a hidrografia (ZMITROWICZ, W. 1986 p.1) alguns caminhos se consolidaram levando aos principais pontos de interesse da época. Segundo Porto, quatro deles eram os principais: um caminho em direção às terras de Tebyriçá e ao Guarepe (atual Luz, pelas atuais ruas Quinze de Novembro e Florêncio de Abreu, outro para o Anhangabaú e aldeia de Pinheiros (pela atual rua Direita), um caminho à taba de Caiuby e Caminho do Mar, e outro para o atual Ibirapuera (pelas hoje avenidas Liberdade e Vergueiro) (PORTO, A. 1992 p.10).

Também em função do relevo, da hidrografia e principalmente de estratégias de defesa surgiram o arruamento e as novas edificações (ZMITROWICZ, W. 
1986 p.1)(MÜLLER, N. 1958 p.145).

Em 1558 São Paulo foi elevada a categoria de Vila. Em 1560 São Paulo passou a ter Conselho Municipal e Pelourinho, pois, por ordem de Mem de Sá os moradores da Vila de Santo André foram obrigados a se transferirem para São Paulo (PORTO, A. 1992 p.11).

Já nessa época se formou o conjunto de caminhos que viria a ser conhecido como "Triângulo", constituído pelas atuais ruas Direita, Quinze de Novembro e São Bento. (LEMOS, C. 1998 p.33)(MORSE, R. 1954 p.31)(TOLEDO, B. 1981 p.13). Nos limites do terreno, entre o final do século XVI e início do século XVII novas ordens se instalaram em São Paulo Carmelitas (1594), Beneditinos (1598/1600), Franciscanos (1640, a partir de 1642 no atual local)(ANDRADE, F. 1966 p.88).

Existia nesse período uma exigência para que as ordens religiosas obedecessem a uma distância mínima entre suas edificações, ao que tudo indica, nem sempre cumprida, mas que influiu na ocupação e na forma que as cidades adquiriram, como afirma Andrade:

“Conquanto,...não possamos concluir pela obediência ou não das regras de distâncias inter-conventos, a análise das Atas das Câmaras dos Registros e das Cartas de Datas de Terras, em especial aquelas referentes á cidade de São Paulo, permite-nos afirmar que os estabelecimentos religiosos que primeiro se incorporaram à vida urbana brasileira guardaram, entre si, distancias apreciáveis, deixando de permeio amplos espaços vazios, não construídos e pouco utilizados para funções preponderantemente urbanas. Fica nos uma impressão que tais vilas teriam crescido numa primeira etapa, para dentro de si mesmas, preenchendo os vazios com os pequenos núcleos 
de casario que iam se formando em torno às casas religiosas, verdadeiras comunidades acolhidas à sombra das únicas instituições que, na época, podiam oferecer proteção e exercer a orientação para a vida pessoal e coletiva (ANDRADE, F. 1966 p.89)

Em 1575 foi construído o edifício da Câmara, pois anteriormente as reuniões eram realizadas em residências particulares (MORSE, R. 1954 p.32). Segundo Richard Morse, no final do século XVI a Vila era constituída de aproximadamente 120 casas. Bens particulares e objetos domésticos importados valiam mais do que casas na cidade. O sistema social era bem hierarquizado, com posições sociais estabelecidas. O núcleo urbano era cercado por aldeias indígenas, vivendo isolado e na pobreza, sendo a agricultura de subsistência. O meio rural era preponderante sobre o urbano e grande parte dos habitantes residia em sítios e fazendas, se deslocando para a cidade em ocasiões especiais como eventos religiosos ou políticos (MORSE, R. 1954 p.31,32,36)(PORTO, A. 1992 p.13).

No início do século XVII surgiram as Bandeiras, que se prolongariam pelo século XVIII. Segundo Tito Lívio Ferreira, as Bandeiras surgiram primeiro como instituições de defesa, mas logo foram se formando para busca de alguma riqueza, uma vez que a pequena Vila e sua região, devido a sua pobreza, pouco tinham a oferecer (FERREIRA, T. 1968 p.61)(SÃO PAULO (PMSP/SERA) 1992 p.23). Afirma a publicação do governo do Estado: "Pode-se considerar o bandeirante como fruto social de uma região marginalizada, cujas ações estavam voltadas a tirar o máximo proveito das brechas que a economia colonial eventualmente oferecia para a obtenção de lucros rápidos. A caça ao Índio para a escravização apresentou-se como ideal 
para esse tipo de ação. As primeiras expedições dos bandeirantes paulistas partiram, assim, com essa finalidade "(SÃO PAULO (PMSP/SERA) 1992 p.23). Ao fator econômico, Richard Morse acrescenta o fator cultural, que atribui à miscigenação da sociedade paulista colonial papel relevante na constituição do movimento bandeirante (MORSE, R. 1954 p.34).

Como centro irradiador dessas expedições, que atingiam cada vez mais áreas distantes, São Paulo passou a ser também o centro dos caminhos consolidados por essas bandeiras (MATTOS, D. 1958 p.26).

As bandeiras esvaziaram ainda mais a pequena Vila (SÃO PAULO (PMSP/SERA) 1992 p.26)(PORTO, A. 1992 p.15), principalmente após a descoberta de ouro na região de Minas Gerais no final do século XVII (SÃO PAULO (PMSP/SERA) 1992 p.23).

Essa descoberta de ouro trouxe uma maior preocupação por parte dos portugueses para com sua colônia, o que os fez introduzir mudanças administrativas para reduzir a autonomia então existente (MORSE, R. 1954 p.34). Conflitos em torno das riquezas recém-descobertas culminaram com a Guerra dos Emboabas. Em conseqüência disso em 1709 foi criada a Capitania de São Paulo e Minas, separada do Rio e São Paulo foi elevada à categoria de cidade em 1711 (SÃO PAULO (PMSP/SERA) 1992 p.23, 24).

Segundo Andrade, a legislação aplicada às cidades brasileiras inicialmente foi a portuguesa, mesmo que não perfeitamente adaptada às condições locais. Essa adaptação,no entanto, ocorreu apenas algum tempo mais tarde. Ao contrário das ordenanzas espanholas muito mais específicas, os documentos que orientaram as primeiras atividades urbanas no Brasil eram muito mais vagos, se preocupando muito mais com a organização administrativa e a 
justiça (ANDRADE, F. 1966 p. 15,34,36). Às Câmaras de Vereadores cabiam a administração das cidades (SÃO PAULO (PMSP/SERA) 1992 p.15). Cabiam a elas, por exemplo, resolver problemas de manutenção, mas também questões policiais e jurídicas como, por exemplo, a distribuição de terras através da concessão ou retirada de datas, cuja propriedade demandava uma efetiva ocupação (SÃO PAULO (ESTADO) 1992 p.11,16)(ANDRADE, F. 1966 p.36)(ROLNIK, R. 1997 p.21).

São Paulo continuava ainda pobre com a predominância do meio rural sobre o urbano persistindo. O Pátio do Colégio funcionava como centro (MÜLLER, N. 1958 p.128) religioso, administrativo e até mesmo comercial. Era o ponto de encontro nas festas religiosas, ponto de convergência dos caminhos que levavam à cidade, ponto de partida das Bandeiras, local de leitura dos editais da Câmara e no século XVIII, local onde se encontravam os edifícios do Correio e do Fisco (PORTO, A. 1992 p.18)(FERREIRA, M. 1971 p.19)(MÜLLER, N. 1958 p.129).

No início do século XVIII a cidade já contava com 400 casas, havendo uma expansão maior de seu núcleo urbano e rural, pelo aumento da concessão de terras (SÃO PAULO (PMSP/SERA) 1992 p.27,28).

Ainda no século XVIII, em 1745 foi criado o bispado de São Paulo, fato relevante para a época, como afirma a publicação do Governo do Estado: "Em meados do século XVIII, a 29 de abril de 1745, era criado o bispado de São Paulo. Completava-se assim o quadro administrativo da cidade, que, pelo padrão da época, não podia prescindir da administração eclesiástica" (SÃO PAULO (PMSP/SERA) 1992 p.28)

Com o passar dos anos, as bandeiras foram se tornando cada vez mais 
comerciais, sendo sucedidas pelas tropas. Afirma Morse:

"A figura dominadora do bandeirante marcial e seminômade cedeu lugar à do fazendeiro patriarcal e à do esperto comerciante urbanizado. Rotas fluviais e terrestres desenvolveram-se entre São Paulo e Cuiabá, na região do ouro recentemente aberta. A era das bandeiras cedeu lugar a das monções e tropas de mulas."(MORSE, R. 1954 p.35)

A partir de meados do século XVIII, portanto, aumentou a importância comercial de São Paulo. Devido a sua posição geográfica e aos caminhos já abertos anteriormente a cidade se beneficiou do comércio de gado do Rio Grande do Sul para o Rio de Janeiro e do crescimento do açúcar no interior da Província de São Paulo. Segundo Bacelli, a cidade "...torna-se um importante entreposto comercial, um 'porto seco'...freqüentado por fazendeiros, senhores de engenho, tropeiros e comerciantes..." (BACELLI, R. 1982 p.15). Afirma Morse:

"A localização estratégica de São Paulo na entrada do Caminho do Mar, servindo como ponto de recepção e distribuição para o planalto, deu-lhe vantagem comercial desde os primeiros anos. Esta vantagem se fortaleceu à medida que o século XVIII via o crescimento da população regional, uma agricultura mais próspera e a intensificação das trocas inter-regionais com o Sul (Rio Grande), o Noroeste (Mato Grosso), o Norte (Minas Gerais) e o Nordeste (Rio)"(MORSE, R. 1954 p.37)

Tropas de mulas carregando mercadorias circulavam por estradas precárias, agora já em número maior, fugindo das regiões difíceis e inundáveis (LANGENBUCH, J. 1971 p.25). Tal transporte era precário, obrigando tais tropas a paradas constantes. Desta forma, ao longo dos caminhos dessas 
tropas foram se formando propriedades rurais e, sobretudo, pousos, que aglutinavam uma série de serviços relacionados à manutenção das mesmas. Muitos desses pousos formariam em torno de si futuros bairros de São Paulo, e mesmo cidades e vilas no interior da Província (DOREA, A. 1982 p.17)(HOMEM, M. 1980 p.23)(ZMITROWICZ, W. 1986 p.3 e 4)(LANGENBUCH, J. 1971 p.25).

Nessa época a cidade já apresentava algum desenvolvimento, chegando a uma população de 8.000 habitantes em 1790 (SÃO PAULO (PMSP/SERA) 1992 p.29), e alguns prédios maiores já haviam sido construídos, como afirma Porto:

"Até fins do século XVIII, a área da cidade era pouco maior do que o primitivo núcleo quinhentista. A fisionomia do burgo paulistano era marcada por alguns prédios avantajados, como sejam: a Casa da Câmara e Cadeia, o Hospital Militar, o Quartel de Voluntários Reais. O centro urbano era triangular, delimitado pelos rios Tamanduateí e Anhangabaú. Sobre estes, havia seis pontes: a do Carmo, no fim da ladeira desse nome; a do Fonseca, no fim da atual rua Glicério; a do Miguel Carlos, na futura rua da Constituição ; a do Açu ou do Marechal, no denominado 'Anhangabaú de Baixo'; e a do Lorena, no Piques. Uns 30 metros adiante da ponte do Açu havia outra pequena ponte, no chamado 'beco do sapo'." (PORTO, A. 1992 p.32)

O comércio no interior da cidade também alcançou algum desenvolvimento, principalmente nas ruas da Quitanda, Álvares Penteado, Largo da Misericórdia e rua São Bento e já no início do século XIX na rua das Casinhas (hoje do Tesouro) (PORTO, A. 1992 p.32)(ZMITROWICZ, W. 1979 p.71).

Em 1815 São Paulo passou a ser capital da Província (DOREA, A. 1982 p.17) 
e em 1822, com a independência, recebeu o título de Imperial Cidade (SÃO PAULO (PMSP/SERA) 1982 p.34). Nesse período, como afirma Bacelli São Paulo se consolidou como "...centro polarizador de seus arredores, um ponto para onde as estradas da Província convergiam..." (BACELLI, R. 1982 p.15)(LANGENBUCH, J. 1971 p.76, 79) (SILVA, R. 1958 p.44). Apesar de algum desenvolvimento econômico, no início do século XIX São Paulo ainda pequena, possuía um aspecto provinciano. Entretanto, em 1827 foi criada a Academia de Direito no Convento de São Francisco (SÃO PAULO (PMSP/SERA) 1992 p.33).

Com os estudantes, a cidade alcançou grande desenvolvimento intelectual, passando a ser palco de manifestações culturais, surgindo hotéis, casas de espetáculo, teatros (SÃO PAULO (PMSP/SERA) 1992 p.34)(PORTO, A. 1992 p.41, 50), e o Largo de São Francisco tornou-se o local mais vital da cidade (FERREIRA, M. 1971 p.45).

Contudo, tal desenvolvimento urbano alcançado com o título de Imperial Cidade e principalmente com a Academia ainda foi limitado, como afirma a publicação do Governo do Estado:

"Naturalmente, o benefício imperial não conseguia disfarçar a pobreza provinciana da cidade, que caia na mesma pacatez sempre que os estudantes saíam de férias. São Paulo continuava relativamente pobre e desinteressante tanto como eixo econômico quanto como centro de decisões políticas. É certo que a cidade desempenhava o papel de entreposto comercial graças à sua privilegiada posição geográfica, mas durante esse primeiro período do século XIX o setor de subsistência da economia na Província ainda assumia maior relevo do que o setor voltado para o mercado externo. Assim, a parcela da 
acumulação de capital que poderia estar sendo carreada para o centro administrativo era de pequena monta, incapaz de provocar um maior crescimento"(SÃO PAULO (ESTADO) 1992 p.34)

Cabia a Câmara a administração da cidade. Afirma Zmitrowicz:

“O 'Concelho Municipal', apoiado no 'Regimento das Câmaras Municipais' que regulamentou as competências estabelecidas pela Constituição de 1824, cuidava da administração de todo o Município, controlada cada vez mais, a partir do Ato Adicional de 1834, pelo Governo da Província,..." (ZMITROWICZ, W. 1979 p.77)

A respeito da Câmara Municipal, afirma a publicação do Governo do Estado: "Na cidade de São Paulo, a Câmara Municipal limitava-se à vigilância da população quanto ao uso moral, econômico e higiênico do meio. Os serviços e melhorias públicas eram dados por empreitada, através de pregão público. $O$ pequeno aparato municipal contava com colaborações irregulares de comissões de cidadãos-proprietários, comerciantes, profissionais liberais e 'letrados' - ou de peritos contratados para situações específicas"(SÃO PAULO (PMSP/SERA) 1992 p.35)

Segundo Andrade, em 1835, foi criado o cargo de Prefeito, logo revogado em 1838 porque contrariava o regimento da Câmara e seus interesses políticos (ANDRADE, F. 1966 p.244, 245).

Houve uma preocupação maior no controle da propriedade, lei de 1836 facilitou a desapropriação de imóveis por utilidade pública e em 1850 a legislação regulamentou a posse de propriedades através de registro legal (ROLNIK, R. 1997 p.23).

Nesse período São Paulo já centralizava seus arredores, como afirma 
Langenbuch. Os aldeamentos indígenas já haviam perdido suas características para se transformarem em povoados caipiras" (LANGENBUCH, J. 1971 p.75). Ainda, segundo Langenbuch, a cidade era cercada por dois cinturões concêntricos, o primeiro deles próximo ao núcleo urbano chamado de cinturão das chácaras, utilizadas principalmente como residências, e secundariamente para abastecimento, e o segundo deles conhecido como cinturão caipira, responsável pelo abastecimento da capital, mas não totalmente organizado em sua função. Distante do núcleo urbano, mas ainda dentro do "cinturão caipira", também se localizavam as atividades que demandavam grandes espaços ou que eram consideradas repulsivas por alguma razão, como cemitérios, casas de pólvora, hospitais, etc.. (LANGENBUCH, J. 1971 p.76). Em 1839 a população do Município era de 21.933 habitantes, sendo que $43 \%$ em zona urbana (SÃO PAULO (PMSP/SERA) 1992 p.34).

A respeito da primeira metade do século XIX, Zmitrowicz descreve as atividades na cidade como bem simples. A cidade era abastecida pela produção agrícola de suas redondezas. A produção industrial era ainda artesanal, causando pouco incômodo a população local (ZMITROWICZ, W. 1979 p.69, 70). Sobre o comércio afirma Zmitrowicz:

"A distribuição de bens produzidos na região constituía a principal atividade varejista da cidade. Predominava o comércio de alimentação, os produtos de fácil deterioração sendo vendidos em tabuleiros, principalmente nas ruas do Cotovelo e do comércio, (frutas e hortaliças, bem como doces e petiscarias), no Largo do Rosário (principalmente doces e petiscarias), e no Largo da Misericórdia, onde estacionavam as 'quitandeiras. Produtos de maior duração 
eram vendidos na rua das Casinhas onde a Câmara Municipal destinou sete pequenas construções 'escuras e esfumaçadas' ao comércio de gêneros alimentícios em geral. Além disso, nos Largos de São Bento e do Palácio, São Francisco, Carmo e São Gonçalo, bem como no Campo da Luz, realizavam-se feiras para venda dos produtos das chácaras e sítios. O comércio de quitanda, com seu ruído e movimento, foi um dos motivos do afastamento do uso residencial das vizinhanças do Largo da Misericórdia. “(ZMITROWICZ, W. 1979 p.71)

As construções eram de taipa, a água vinha de chafarizes, riachos ou tonéis, o lixo espalhado a ermo (ZMITROWICZ, W. 1979 p.71, 72), a pavimentação e a iluminação precárias (ZMITROWICZ, W. 1979 p.74).

Podemos concluir, portanto, que foram ainda pequenas as transformações no uso do solo no período, tendo ocorrido apenas um aumento de funções dentro do perímetro urbano, e também, como vimos nos parágrafos anteriores, um pequeno deslocamento de residências em função dessas atividades. 


\section{2 - PERÍODO DO CAFÉ}

Segundo Morse e Simonsen, o café foi plantado pela primeira vez no Brasil em 1727. No início do século XIX, com o aumento da procura internacional pelo produto, aumentou a produção brasileira, principalmente no Vale do Paraíba, sendo escoado pelo porto do Rio de Janeiro (MORSE, R. 1954

p.157)(SIMONSEN, R. 1938 p.9, 10).

Com o desenvolvimento social e econômico alcançado anteriormente, São Paulo se consolidou como centro administrativo, político, comercial e cultural da Província. Com o esgotamento das terras do Rio de Janeiro e do Vale do Paraíba, o café passou a ser cultivado com maior intensidade principalmente no noroeste do Estado de São Paulo, em terras produtivas. Com isso, São Paulo se viu então em uma posição estratégica, entre a lavoura e o porto exportador de Santos. Embora em um primeiro momento o sucesso da cultura do café no interior tenha contribuído para um esvaziamento da cidade, a partir de um certo período, principalmente após 1860, a cidade passou a ser beneficiada pela riqueza trazida por ela. Portanto, podemos atribuir ao café o início do grande desenvolvimento que a cidade alcançou nesse período. (PORTO, A.1992 p.47)(ROLNIK, R.1990 p.74)(SIMONSEN, R. 1938 p.10,12,55)(HOMEM, M. 1980 p.9)(OSELLO, M. p.80). Afirma a publicação do Governo do Estado de São Paulo:

“...enriquecida e diversificando-se graças à cultura da rubiácea, a capital paulista pode então reunir o fator modernizante representado pelos acadêmicos com a base material real para a modernização..." (SÃO PAULO (PMSP/SERA) 1992 p.34).

Ocorreu um aumento numérico e um grande enriquecimento da elite paulista, 
que ao contrário da pequena elite dos ciclos econômicos anteriores, passou a procurar cada vez mais a capital como local de residência.(SÃO PAULO (PMSP/SERA) 1992 p.41) (MORSE, R. 1938 p.283).

Com o café (cujos negócios necessitavam muito mais da vida urbana), uma série de novas atividades passou a ser desenvolvida na cidade, como operações bancárias, negócios de mão de obra, etc., provocando também um aumento da população de classe média, quase inexistente nos períodos anteriores. Com isso aumentou o comércio e a imprensa tornou-se mais ativa, reivindicando também melhorias urbanas (SÃO PAULO (PMSP/SERA) 1992 p.37 e 38)(MARTINS, M. 1980p.43)(MORSE, R. 1954 p.176). O café igualmente estimulou o aparecimento de cidades no interior do Estado (MARTINS, M.1980 p.43).

Já no início da segunda metade do século XIX até mais ou menos 1875/1889 houve um início de concentração de residências de melhor padrão no Carmo, Liberdade, Luz, Santa Ifigênia e dentro do próprio Triângulo (VILLAÇA, F. 1998 p.175)(BRUNO, E 1954 p.1041).

O café atraiu grande contingente de mão de obra, que se intensificou após a abolição da escravatura em 1888. Esses imigrantes vieram principalmente da Itália (ROLNIK, R. 1990 p.74), embora também tenha havido significativa imigração de pessoas de outras nacionalidades. Além disso, a Abolição colaborou na liberação de capitais para novos empreendimentos. A proclamação da República em 1889 permitiu que os Estados ganhassem maior autonomia administrativa (ROLNIK, R. 1990 p.74)(HOMEM, M. 1980 p.19,21)(OSELLO, M. 1983 p.80).

Nesse período as principais atividades relacionadas ao planejamento e ação 
do poder público estão relacionadas a empreendimentos capazes de dar suporte à economia cafeeira, serviços de saneamento e embelezamento da cidade, visando adapta-la aos novos padrões da época.

A primeira grande obra realizada no início do período do café, em meados do século XIX, foi a ferrovia. Afirma Zmitrowicz:

"As ferrovias nasceram não como um serviço de utilidade pública, mas como um empreendimento econômico regional, para o qual concorreram o desenvolvimento geral da Província, com a intensificação e deslocamento territorial da cultura cafeeira, e a garantira de 5\% sobre o valor do capital empregado, oferecida pelo Governo Imperial e reforçada em seguida pelo Governo da Província de São Paulo de forma a chegar a 7\% ao ano." (ZMITROWICZ, W. 1986 p.4)

A implantação das ferrovias, visando facilitar o escoamento da produção cafeeira, provocou grandes transformações na cidade e região, realçando ainda mais o papel centralizador da cidade (PORTO, A. 1992 p.52)(ZMITROWICZ, W. 1986 p.5). Afirma Zmitrowicz:

" Observa-se, contudo, que mesmo sendo composta de linhas implantadas pela iniciativa privada, sem coordenação governamental e sem seguir um plano preestabelecido, a rede ferroviária da Província de São Paulo se desenvolveu, impulsionada pelo interesse dos proprietários das áreas de produção, formando um sistema relativamente coerente, em forma de um funil convergente na Capital, que teve realçada a sua condição de ponto de passagem obrigatória entre as grandes extensões territoriais do interior e $o$ porto de Santos."(ZMITROWICZ, W. 1986 p.5)

A ferrovia foi implantada nas várzeas porque elas requeriam obras muito 
menores devido a seu relevo plano. Além disso, tais terrenos eram desvalorizados em razão das enchentes, o que diminuía o custo de sua implantação (LANGENBUCH, J. 1971 p.99). A ferrovia começou a atrair atividades para suas proximidades. As estações passaram a ser "pólos de desenvolvimento", dando início a alguns novos núcleos (LANGENBUCH, J. 1971 p.107).

Com a expansão da cidade e a valorização representada pelas ferrovias nas áreas de várzeas (ZMITROWICZ, W. 1986 p.7), além do reconhecimento da insalubridade das regiões inundáveis, iniciou-se a preocupação com o saneamento das mesmas, principalmente aquelas próximas ao centro da cidade. Desta forma, foram retificados os córregos do Anhangabaú e Tamanduateí e posteriormente a construção dos Parques D. Pedro e Anhangabaú, já no século XX (ZMITROWICZ, W. 1986 p.7)(WAKISAKA, T. 1991 p.22, 23).

Começou a haver uma substituição das construções de taipa por construções de tijolo a partir de 1879. João Teodoro como Presidente da Província entre 1872 e 1875 promoveu uma remodelação da área do Triângulo (PORTO, A. 1992 p.52 e 91)(OSELLO, M. 1983 p.88).

A cidade e o Estado receberam infra-estrutura, principalmente implantada a partir de concessões às empresas privadas como São Paulo Railway Company (1860), The São Paulo Gas Company Ltda (1869), Companhia Cantareira de esgotos (1875), The São Paulo Tramway and Power Co Ltda (1900) (ROLNIK, R. 1990 p.74). Afirma Zmitrowicz:

"Outro empreendimento que enfatizou a importância das obras de saneamento e de comunicação ao longo desse eixo norte sul foi o da 
Companhia Cantareira de Esgotos, encampada pelo Governo do Estado em 1892, quando foi criada a Repartição de Águas e Esgotos (RAE). A delimitação dos Parques da Cantareira e das Nascentes do Ipiranga, para proteção dos mananciais que abasteciam as represas e a construção das adutoras em direção à cidade tiveram uma influência não só sobre a implantação imediata de linhas de transporte como também a longo prazo, constituindo-se barreiras à expansão urbana futura. "(ZMITROWICZ, W. 1986 p.7)

Como conseqüência das obras de abastecimento de água foi construída em 1894 a linha de Tramway, que passou também a servir a passageiros e a colaborar para o desenvolvimento da região sul. Para implementação da rede de esgotos também o Tietê foi parcialmente retificado o (ZMITROWICZ, W. 1986 p.8).

A imigração para a capital fez com que a população da cidade crescesse, criando uma série de fortes demandas (ROLNIK, R. 1990 p.74).

Tais fatos, aliados a infra-estrutura (que segundo Rolnik consolidou a “ distinção entre espaço rural e urbano") (ROLNIK, R. 1990 p.74), a disponibilidade de capitais que já não eram aplicados na ferrovia, a instabilidade econômica e política, o aumento dos impostos e a desvalorização dos imóveis rurais valorizaram as terras urbanas e transformaram o mercado imobiliário em um negócio lucrativo. A cidade se expandiu. Muitas chácaras começaram a ser desmembradas, inicialmente nas proximidades do Triângulo e posteriormente até mais distantes. Começaram a surgir as primeiras indústrias, como veremos a seguir. Surgiram também os loteamentos. Entre 1882 e 1890 Glette e Nothmann lotearam os Campos Elíseos como residencial de elite. Alcançaram grande lucro, o que 
estimulou novos loteamos, tanto destinados à elite como Higienópolis e Paulista, como populares (Brás, Bela Vista, Bom Retiro, Lapa, etc..), num fenômeno que se estenderia por muitas décadas ainda, e que criaria, principalmente junto às várzeas, bairros mistos, residenciais e industriais. Nas beiradas dos bairros de elite, como nas transversais da Av. Paulista, Santa Cecília, Vila Buarque, Consolação, etc., surgiram bairros ocupados por uma população de poder aquisitivo um pouco maior do que a proletária, mas bem menos abastada do que a que habitava os bairros de elite (TARALLI, C. 1993 p.82) (DOREA, A.1982 p.26)(HOMEM, M. 1980 p.24).

Em 1892 foi construído o viaduto do chá facilitando a comunicação com o Anhangabaú.

Para atender a uma elite urbana cada vez mais europeizada culturalmente, o comércio se sofisticou (MÜLLER, N. 1958 p.130, 131) (OSELLO, M. 1983 p.49)(HOMEM, M. 1980 p.25).

A princípio o comércio ocupou a parte térrea dos sobrados (MÜLLER, N. 1958 p.132) para depois ocupá-los totalmente. Desta forma, na década de 1880/1890 o Triângulo se consolidou como área comercial e de serviços. Nos demais bairros, o comércio era quase nulo (BRUNO, E. 1954 p.1046). Com a tomada da área do Triângulo por esse comércio e serviços sofisticados ocorreu um afastamento das residências de elite para os novos loteamentos: Campos Elíseos e, posteriormente, Higienópolis e Avenida Paulista. Afirma Homem de Mello:

" $A$ explosão demográfica a partir dos anos 1870 determinarão, assim como as novas atividades econômicas, a compartimentação da cidade por funções" (HOMEM, M. 1980 p.23) 
“O antigo Triângulo central, representado hoje pelas ruas Direita, São Bento e XV de Novembro, perdeu sua função residencial e concentrou as atividades de comércio, administrativas, religiosa e de lazer. Ali se aglomeraram bancos, lojas, cafés, restaurantes, hotéis, teatros e cineteatros, ao lado das antigas igrejas “(HOMEM, M. 1980 p.24)

Afirma Müller que o Triângulo se definiu como área comercial:

"Com a continuidade desse processo, acabou por definir-se o Triângulo como área puramente comercial e, assim, durante cinco décadas, a partir de fins do século XIX, torna-se ele o verdadeiro centro de São Paulo...” "Transformou-se no 'coração' da Paulicéia e recebeu, dos paulistanos a designação de cidade, em contraposição aos bairros existentes em sua periferia” (MÜLLER, N. 1958 p.132)

O fator cultural foi um dos mais importantes nessa transformação, como afirma Lemos:

“Ao nosso ver, essa expulsão das habitações do centro histórico, sobretudo daquelas das famílias bem postas, se deveu a fatores culturais em que estava implícito o repúdio aos edifícios de apartamentos residenciais. Enquanto na Europa, desde o tempo dos romanos, para o proletariado e para a burguesia, foram absolutamente normais prédios de habitações coletivas unifamiliares distribuídas em vários pavimentos; aqui entre nós essa solução chegou tardiamente, só na década de 20 deste século, já na égide do concreto armado e destinada à classe média e somente depois é que se destinou aos ricos e agora é que chega aos pobres. Por isso, o ecletismo de tijolos desconheceu o prédio de apartamentos na região do Triângulo e daí o destino do Centro paulistano de ficar desabitado à noite, mormente depois do abandono das 
residências sobre as lojas, cujos espaços também acolheram escritórios e consultórios. Com esse inicial processo de verticalização, o Centro acabou saindo de seus limites históricos e se espelhou pelas cercanias; ostentando um programa complemente diverso daquele original, definido nos meados do Império " (LEMOS, C. 1998 p.34)

Em 1872 São Paulo ganhou bondes de tração animal, o que melhorou substancialmente as condições de transporte na cidade.

Esse período também foi marcado por uma preocupação maior com a salubridade. Em 1875 foi elaborado o Código de Posturas, sistematizado, revisto e ampliado em 1886. Por esses códigos a municipalidade preocupavase com alinhamento, demarcação de propriedades mas também com os cortiços, que foram proibidos de se instalarem na área central. Essa proibição reforçou a tendência da população de baixa renda ocupar a periferia, segundo Rolnik (ROLNIK, R. 1997 p.32,33, 35, 48).

Outra legislação importante foi o Código Sanitário Estadual de 1894 e a conseqüente criação do Serviço Sanitário (ROLNIK, R. 1997 p.38). Nesse período, portanto, aumentou a preocupação em regulamentar os incômodos gerados pelas atividades comerciais e fabris no centro da cidade (ZMITROWICZ, W. 1979 p.88)

Segundo Zmitrowicz:

"Pode-se concluir, portanto, que na segunda metade do século XIX a aceleração repentina do crescimento da cidade, apoiada na criação de novos sistemas de transporte regional, impôs a necessidade de uma série de investimentos específicos, principalmente nos setores viários, de abastecimento de carne, bem como medidas administrativas baseadas nas 
posturas codificadas nos anos de 1873,1875 e 1886, visando proteger os habitantes dos efeitos das transformações de uso corrente.

Entretanto, no final do século, o desenvolvimento se acelerou extraordinariamente, perturbando ainda mais o equilíbrio que se procurava restabelecer entre as diversas funções "(ZMITROWICZ, W. 1979 p.94) No começo do século XX, devido à saturação do café no mercado mundial, este entra em declínio, (MORSE, R. 1954 p. 281,282) que se acentuaria após a grande crise de 1929.

Concluímos, portanto, que nesse período ocorreram importantes alterações no uso do solo, principalmente com instalação de novos usos através dos loteamentos. As residências de elite passaram a se concentrar em loteamentos das antigas chácaras, especificamente desenhadas para receber esse tipo de uso, como Campos Elíseos, Higienópolis, avenida Paulista. Bairros de classe média (ou seja, de residências melhores do que as dos loteamentos operários) começaram a surgir principalmente nas bordas desses loteamentos de elite, como em Santa Cecília, Consolação, Vila Buarque.

Surgiram também os primeiros loteamentos populares e industriais no Brás, Bom Retiro, Bela Vista, etc., que veremos com maiores detalhes no ítem sobre a indústria.

Como transformação de uso, a principal ocorreu, portanto, na área do Triângulo, que concentrando inúmeras atividades (inclusive residências de classe abastada) se definiu como área comercial entre 1880/1890, tornando-se ponto de convergência da elite. 


\section{3 - PERÍODO DA INDÚSTRIA}

Ainda durante o período do café nasceu a indústria. O capital do café, a disponibilidade de energia, matérias primas (principalmente do Estado de São Paulo), mão de obra (pela imigração constante ou liberada pelo café) e mercado consumidor, aliados às facilidades de transporte propiciadas principalmente pela ferrovia, fizeram com que a cidade começasse a se industrializar, já no final do século XIX, como vimos. Inicialmente com pequenos estabelecimentos semi-artesanais no próprio Triângulo, para depois se instalarem nas várzeas, principalmente ao longo das ferrovias, que propiciavam um ótimo meio de transporte para recebimento de matérias primas e escoamento de produção. Além disso, havia a abundância de água, os terrenos eram extensos, planos e de baixo custo, uma vez que tais terrenos haviam sido desprezados pela urbanização em razão das enchentes, que os tornavam insalubres. Rapidamente, cresceram os bairros operários próximos às várzeas (LANGENBUCH, J. 1971 p.110,141,144)(ZMITROWICZ, W. 79 p.84).

Em 1898 Antônio Prado assumiu o cargo de prefeito (período de 1898-1911), promovendo uma série de melhorias na região central, continuadas por seu sucessor Raimundo Duprat (1911-1914), que incluíam o alargamento de ruas perimetrais ao Triângulo como Libero Badaró, Boa Vista e Benjamin Constant (PORTO, A. 1992 p.92)(SOMEKH, N. 1981 p.65, 66).

As atividades comercias no início do século XX já se expandiam pela Libero Badaró, Boa Vista, General Carneiro e Ladeira Doutor Falcão (MÜLLER, N. 1958 p.137).

Nas primeiras décadas do século, a cidade, e principalmente o centro já 
apresentavam alguns problemas, sendo um deles o congestionamento.

Em 1900 foram implantados os bondes elétricos pela Light (ZMITROWICZ, W. 1986 p.9). Afirma Zmitrowicz:

"Excetuando-se este e os eixos em direção aos Parques da Cantareira e das Cabeceiras do Ipiranga, que também atraíam turistas e seriam futuramente obstáculos à urbanização, a cidade continuou a se desenvolver basicamente ao longo dos antigos caminhos agora reforçados por linhas de bonde e das estradas de ferro regionais, acrescidas de novas estações servidas por tens de subúrbio. Entretanto, às vezes o traçado das linhas de bonde afastava-se um pouco dos caminhos tradicionais, dando preferência a vias novas abertas nos loteamentos, servindo assim melhor tanto aos interesses dos moradores como aos dos proprietários dos loteamentos." (ZMITROWICZ, W. 1986 p.10) Ainda nas primeiras décadas do século XX, São Paulo começou a apresentar alguns problemas decorrentes das atividades econômicas desenvolvidas sem regulamentação e soluções começaram a ser debatidas.

Em 1911 houve um concurso para o qual foram apresentadas quatro propostas: As novas avenidas de São Paulo de Alexandre de Albuquerque, o Projeto da Prefeitura de Victor da Silva Freire e Eugenio Guilhem, o Projeto da Secretaria da Agricultura, Vias e Obras Públicas de Samuel das Neves e um projeto de J. A Bouvard. A primeira proposta de Alexandre de Albuquerque estava ligada a interesses de proprietários de imóveis e apontava para a abertura de uma série de Avenidas e a reurbanização de Santa Ifigênia, em contra partida requeria o direito de comercialização dos imóveis desapropriados ao longo dessas avenidas, monopólio sobre o transporte da área, os onibus-automóveis, e juros de $5 \%$ por 10 anos sobre $1 / 4$ do custo. 
(ZMITROWICZ, W. 1986 p.11)(WAKISAKA, T. 1991 p.25). Como a proposta não resolvia o problema do congestionamento e possuía elevado custo, não foi aprovada (WAKISAKA, T. 1991 p.25). As propostas de Victor da Silva Freire e Eugenio Guilhem, encaminhada pelo prefeito Antônio Prado e de Samuel das Neves, tinham como objetivo o alargamento de ruas na região central, aumentando ainda mais sua função (WAKISAKA, T. 1991 p.25).

Chamado para analisar as propostas, Bouvard elaborou um relatório, que, segundo Wakisaka "contemplava os diversos interesses que se colocavam enquanto forças políticas”(WAKISAKA, T. 1991 p.25). Parcialmente implementada resultou nos Parques Anhangabaú e Parque Dom Pedro (Várzea do Carmo), além dos alargamentos de ruas centrais, como Libero Badaró, Boa Vista e Benjamim Constant (WAKISAKA, T. 1991 p.25) Bairros de elite continuaram a se instalar à sudoeste da cidade, em continuação a Avenida Paulista, como o Jardim América em 1915 (PORTO 1992 p.116). Afirma Bacelli:

" São Paulo passa a apresentar uma configuração com setores mais diferenciados e áreas funcionais bem definidas: encontramos uma zona comercial no velho centro, paralelamente a um comércio atacadista nas vertentes do Tamanduateí; uma zona com industrialização concentrada nos bairros do Brás, Móoca e Belenzinho; uma zona de características residenciais definidas iniciada nos Campos Elíseos, subindo Higienópolis, atingindo o espigão da Avenida Paulista e descendo em direção ao novo Jardim América." (BACELLI, R. 1982 p.24)

A implantação de infra-estrutura prosseguiu (ROLNIK, R. 1990 p.75) e a cidade continuou a se expandir coordenada pela especulação imobiliária 
(LANGENBUCH, J. 1971 p.133).

Afirma Bacelli:

" No período anterior a 1913 grandes áreas eram encontradas a baixo preço, ou simplesmente tomada pelo sistema de 'grilos', sendo loteadas e arruadas segundo traçado hipodâmico, muitas vezes inadequado à topografia local. Outros terrenos eram ainda ocupados sem que os lotes estabelecessem uma relação racional entre si. Nessa fase da metropolização de São Paulo o espaço urbanizado disponível para habitação é muito superior a demanda. Ainda assim, a especulação imobiliária valoriza artificialmente determinadas áreas, provocando uma carência de lotes acessíveis às camadas mais baixas da população, obrigando-as a adquirir terrenos cada vez mais afastados do centro e sem infra-estrutura. Observa-se também a tendência ao compactamento da cidade, que entretanto, não se realiza imediatamente, os grandes claros na mancha urbana que configuram São Paulo como uma estrutura orgânica fragmentada são o resultado da ação especulatória. " (BACELLI, R. 1982 p.24).

Uma série de leis procurou controlar a especulação imobiliária e a qualidade das edificações como, por exemplo, a lei 1666 de 1913 que procurava regular os arruamentos particulares (ZMITROWICZ, W. 1979 p.106). A pratica de anistiar periodicamente irregularidades legais existentes também surgiu nesse período como, por exemplo, em 1914 com a anistia às ruas irregulares (BARRETO, J. 1997 p.35). Nesse período também foi aprovada a proibição indústrias na avenida Paulista.

Com o bonde ocorreu melhoria no sistema de transportes, o que impulsiona ainda mais a urbanização, em grande parte irregular perante a legislação 
(BARRETO, J. 1997 p.28).

Com a primeira guerra mundial a indústria (principalmente têxtil e alimentícia) alcançou notável crescimento, ocupando de forma mais intensa as áreas de várzeas próximas às ferrovias. Essas áreas também tiveram sua ocupação intensificada por usos residenciais operários, devido ao contínuo aumento populacional e a proximidade dos empregos gerados pelas indústrias (DOREA, A. 1982 p.21,27,28)(BACELLI, R. 1982 p.20)(LANGENBUCH, J. 1971 p.141,144).

Na década de 20, aumentou o número de automóveis e iniciou-se um período de construção de estradas, muitas delas seguindo os antigos caminhos de tropas (LANGENBUCH, J. 1971 p.153). Aumentou a circulação rodoviária (LANGENBUCH, J. 1971 p.200).

Na década de 20 iniciou-se a verticalização do centro, primeiramente com edifícios comerciais e depois residenciais (LEMOS, C. 1998 p.34)(MÜLLER, N. 1958 p.150). A verticalização continuou na década de 30, já atingindo bairros próximos ao centro. Datam da mesma década os primeiros edifícios de apartamentos na Paulista e em Higienópolis. Entre as décadas de 30 e 40 bairros como a Lapa e o Brás começaram a sofrer um crescimento de sua importância comercial, principalmente de caráter popular consolidando-se como subcentros (VILLAÇA, F. 1978 p.57).

Na década de 20 a chamada Cidade Nova (Anhangabaú e Pç da República) começou a sofrer influência do centro. Na década de 30 com a mudança do Mappin essa influência se intensificou e nos anos 40 a região já se tornou comercial, integrando-se ao centro (SOMEKH, N. 1981 p.62 e 66).

Segundo Wakisaka, a partir de 1926 iniciou-se um período de grandes obras 
administradas por uma maioria de prefeitos de perfil técnico, oriundos principalmente da Escola Politécnica (WAKISAKA, T. 1991 p.25).

Em 1926, durante a gestão de Pires do Rio a Light apresentou um projeto pelo qual previa uma melhoria no transporte urbano da cidade, exigindo em troca o monopólio de todo sistema. Segundo Wakisaka, a Companhia já começava a sofrer a concorrência dos ônibus (WAKISAKA, T. 1991 p.26). Embora a proposta incluísse até um embrião de metrô e fosse aprovada tecnicamente, o fato da Companhia exigir em contrapartida o monopólio fez com que a proposta não fosse aprovada. Além disso, afirma Wakisaka “... o Plano não foi aprovado pela Prefeitura, por conta do contexto político da época, pois o Partido Democrata de então se posicionou contra os interesses da Light, opondo-se à sua aprovação..." (WAKISAKA, T. 1991 p.27). Com o acirramento da concorrência dos ônibus, e a não execução da proposta, a Light paulatinamente foi abandonando o transporte coletivo, não renovando a concessão em 1941, passando a prestação dos serviços para a Prefeitura. Quanto a legislação a própria municipalidade, na década de 30, incentivou a verticalização, pois exigiu altura mínima de 10 andares para edifícios nas ruas Xavier de Toledo, Sete de Abril, Conselheiro Crispiniano, Vinte e Quatro de Maio, Marconi e Praça da República e 6 andares para a rua São Bento (MEYER, R. 1994 p.5). Segundo Marcondes, o Poder Público, nesse período se restringia a controlar o uso industrial, a altura e os recuos dos edifícios (MARCONDES, C. 1988 p.68).

Em 1929 foi elaborado o Código Arthur Saboya que sistematizou a legislação existente e foi criada uma Comissão para estudar o Zoneamento, ou seja, começou a surgir uma preocupação maior com o planejamento geral. 
Pelo Ato 663 de 1934 algumas áreas foram consideradas estritamente residenciais. A lei 3571/37 determinou para algumas áreas uso residencial, com permissão para apartamentos (MARCONDES, C. 1988 p.68).

Loteamentos de elite continuaram a ser abertos nas décadas de 20 e 30 como Alto da Lapa, Bela Aliança, Jardim Europa, Alto de Pinheiros, Pacaembú, ou seja, localizados principalmente na região sudoeste da cidade.

Durante as décadas de 30, 40 e 50 a cidade se expandiu vertiginosamente (SÃO PAULO (PMSP/SERA) 1992 p.61), principalmente através da abertura de novos loteamentos na periferia. Afirma Langenbuch:

" A maioria dos núcleos suburbanos, que surge com apoio na circulação rodoviária, não se desenvolve em função de nenhum pólo local de atração. Provém de loteamentos cujo lançamento e cuja efetiva ocupação dependem de fatores não geográficos (especulação imobiliária, ' agressividade de vendas ', facilidades oferecidas aos compradores), e da posição geográfica difundida em termos areolarmente mais amplos. Vimos que este tipo de subúrbio, o que denominamos ' subúrbio-loteamento ' teve origem entre 1930 e 1940..." " Muitos dos ' subúrbios-loteamentos' despontam em áreas sitas fora dos principais eixos de circulação rodoviária, junto a estradas secundárias, ainda não servidas por ônibus Os primeiros moradores, quase sempre pessoas humildes, fazem o papel de pioneiros. Por muito tempo deslocam-se a pé à estrada transitada por ônibus. Estes apenas são estendidos ao lugar depois de já contar com povoamento razoável, assegurando rentabilidade à linha. Esse foi o caso da quase totalidade dos 'subúrbios-loteamentos ' surgidos entre 1930 e 1940..."(LANGENBUCH, J. 1971 p.200, 201)

Nessa época os ônibus começaram a ser utilizados em maior escala do que os 
bondes o que reforçou ainda mais o aparecimento de loteamentos e o crescimento explosivo da cidade (LANGENBUCH, J. 1971 p.200). Na década de 30 aumentou também a preocupação da sociedade com os problemas da cidade. Surgiu a SAC (Sociedade dos Amigos da Cidade) em 1934 e segundo a publicação do Governo do Estado 'O poder em São Paulo', ela foi uma antecessora das sociedades amigos de bairros das décadas posteriores, que exerceriam importante papel político. (SÃO PAULO (PMSP/SERA) 1992 p.61).

Em 1930 Prestes Maia apresentou o Plano de Avenidas (elaborado com base em proposta de Prestes Maia e Ulhôa Cintra em 1924). O Plano de Avenidas tinha como proposta básica o desafogamento do centro de São Paulo através da construção de uma série de anéis viários e radiais que desviariam o trânsito da região e melhorariam a circulação por toda a cidade. Abrangente, o plano propunha linhas de trânsito rápido (metrô) e a transferência das linhas férreas para a outra margem do Tietê, além de Parkways e Boulevards (ZMITROWICZ, W. 1996 p.31).

Esse plano deu nova feição ao centro, pois pode ser parcialmente executado (algumas modificações foram feitas pelo próprio autor) a partir de 1938 quando Prestes Maia assumiu a Prefeitura (ZMITROWICZ, W. 1996 p.35)(MEYER, R. 1994 p.4)(GROSTEIN, M. 1994 p.7).

Após os anos 40 começou a ocorrer uma compactação maior da área edificada sem que isso significasse o fim da expansão por novos loteamentos na periferia, configurando ainda mais o chamado padrão periférico de crescimento (ROLNIK, R. 1990 p.76 e 77). A verticalização também se intensificou (LANGENBUCH, J. 1971 p.179,258). 
Igualmente após os anos 40, ainda segundo Langenbuch, as rodovias aceleraram a ocupação industrial nas regiões ainda livres dentro da área de estudo e, principalmente na região da Grande São Paulo (LANGENBUCH, J. 1971 p.258), informação essa com a qual concorda Rolnik, ao afirmar que até os anos 40 a ocupação industrial se deu prioritariamente dentro do Município de São Paulo, a partir dos anos 40 até os anos 70 na região da Grande São Paulo e, após os anos 70, no Estado de São Paulo (ROLNIK, R. p.111). Conforme Décio Saes, uma das conseqüências da industrialização foi o aumento da classe média. Segundo o autor, a classe de trabalho não manual, principalmente constituída por funcionários administrativos e profissionais liberais, constituía apenas 3\% da população trabalhadora no país em 1920, tendo alcançado grande crescimento posteriormente (SAES, D. 1985 p.5). Em 1945, com o fim do Estado Novo, novas relações sociais se estabeleceram, ocorrendo uma democratização da sociedade, o que permitiu a reorganização da Câmara de Vereadores e o restabelecimento da negociação política como forma de ação sobre a cidade (WAKISAKA, T. 1991 p.35, 36)(SÃO PAULO (PMSP/SERA) 1992 p.63) Afirma Wakisaka:

"Por um lado, técnicos afirmando a necessidade de se voltar atenção e a atuação do poder público às precárias condições de vida nas periferias da cidade, por outro, o executivo municipal que começa a orientar suas decisões não mais por critérios técnicos, mas por critérios de legitimação e interesses político-eleitorais" (WAKISAKA, T. 1991 p.36)

A periferia começou a reivindicar água luz, asfalto e equipamentos públicos através das sociedades amigos de bairros, sendo atendida através do clientelismo político, que também beneficiou especuladores imobiliários e 
empresas ligadas à construção civil (SÃO PAULO (PMSP/SERA) 1992 p.74). Nesse período também começou a ser montada a estrutura administrativa de planejamento (WAKISAKA, T. 1991 p.37). Em 1947 foi criado o departamento de urbanismo que elaborou uma série de projetos para a cidade, inclusive projetos de zoneamento visando controlar o uso e a ocupação do solo (MARCONDES, C. 1988 p.77).

Em 1949 a Prefeitura encomendou o Relatório Moses, que segundo Wakisaka, diagnosticou a deficiência de transportes, a eminência da expansão de favelas e cortiços e recomendou a adoção de novo um código de obras e também do zoneamento (WAKISAKA, T. 1991 p.37).

São Paulo continuou se expandindo nos anos 50, principalmente com a intensificação da industrialização, agora também incentivada pelo Plano de Metas e voltada para setores mais modernos, como a indústria automobilística. A cidade atraiu ainda grande contingente de trabalhadores, principalmente migrantes nordestinos, que se instalaram principalmente em uma periferia desprovida de infra-estrutura adequada (SÃO PAULO (PMSP/SERA) 1992 p.61)(MARTINS, M. 1980 p.45).

A indústria se compactou, a de menor porte nos bairros do Bom Retiro, Brás, Moóca, Cambuci e as maiores na Lapa de Baixo, no trecho final do rio Pinheiros, na Vila Maria, Vila Prudente (fora da área de estudo) e Vila Leopoldina (ZMITROWICZ, W. 1979 p.120).

$\mathrm{Na}$ década de 50 o comércio de elite começou a se deslocar do centro para a região da Paulista (CORDEIRO, H. 1980 p.163), deixando espaço no centro tradicional para o comércio popular, principalmente nas ruas Quintino Bocaiúva, Direita e São Bento (VILLAÇA, F. 1978 p.296,297,321). Afirma 
Villaça:

"Como o centro caminhava em direção aos bairros residenciais das camadas de alta renda, a parte abandonada ficava voltada para a direção oposta a esse caminhamento, ou seja, para a direção dos bairros populares. Essa parte começou então a ser ocupada pelas lojas e serviços voltados para as populações desses bairros. Foi assim que, à medida que as camadas populares ascendiam como mercado consumidor, suas lojas e serviços começaram a aparecer nos centros de nossas metrópoles, nas áreas abandonadas ou desprezadas pelos estabelecimentos que atendiam às elites. Os centros começaram a apresentar então uma nítida bipartição: o centro das camadas de mais alta renda e o das camadas de mais baixa renda, cada qual voltada para as regiões residenciais das respectivas clientelas..."

“Em São Paulo, o comércio popular ocupou as imediações da praça João Mendes, e ruas do centro velho como a Quintino Bocaiúva até, já na década de 50, tornar as ruas mais tradicionais do comércio das elites que eram a São Bento e principalmente a rua Direita.”(VILLAÇA, F. 1978 p.296, p.297). Os subcentros adquiriram maior importância, parte do transporte coletivo passou a ter esses subcentros como ponto de partida, e não mais o centro histórico, o que reforçou ainda mais o papel polarizador desses subcentros, sem no entanto ameaçar a predominância do centro histórico (OSELLO, M. 1983 p.163).

Com o aumento do consumo, tanto da crescente classe média como das camadas populares e com o crescimento do número de automóveis incentivado pela política econômica da indústria automobilística, o centro histórico teve o problema dos congestionamentos agravado. 
Os órgãos públicos também saíram do centro tradicional. Em 1955 o Parque Ibirapuera começou a receber parte da administração municipal. Em 1965 a administração estadual saiu dos Campos Elíseos para o Morumbí (sendo que já havia deixado o centro histórico para os Campos Elíseos na década de 30) e no final dos anos 60 a Câmara Municipal saiu da Libero Badaró para o viaduto Jacareí (PORTO, A. 1992 p.162 e 173). Inúmeros órgãos públicos também se instalaram na Paulista, em décadas posteriores, como METRO, EMPLASA, COMGÁS, etc.

Na década de 50 uma série de obras viárias foram executadas, principalmente no centro e foi elaborada uma série de diagnósticos sobre a cidade de São Paulo (MARCONDES, C. 1988 p.80).

Em 1954 foi criada a Comissão Orientadora do Plano Diretor do Município, que pretendia coordenar também um Plano Regional com Municípios vizinhos. Contudo, não foi concretizado (MARCONDES, C. 1988 p.79).

Em 1957 foi elaborado o Relatório do Padre Lebret, que, entre outras coisas descreveu São Paulo como monopolar e com seu centro saturado, recomendando a descentralização (WAKISAKA, T. 1991 p.41)(MARCONDES, C. 1988 p.80).

Segundo Marcondes:

"Paralelamente em 1957 foi estabelecida pela primeira vez um índice de aproveitamento máximo para as edificações comerciais (igual a 6,0) e para edificações residências ou turísticas (igual a 4,0) através da lei n.261/57 e a obrigatoriedade de garagens privativas para edifícios coletivos pela lei 5268/57" (MARCONDES, C. 1988 p.84)

$\mathrm{Na}$ década de 60, principalmente, começou a haver maior participação da 
mulher no mercado de trabalho.

Na mesma década, após um período de instabilidade política, instalaram-se os governos militares (SÃO PAULO (PMSP/SERA) 1992 p.84). Em 1965 índices maiores para coeficiente máximo de aproveitamento foram aprovados, o que intensificou a verticalização.

Em 1967 foi criado o GEP (Grupo Executivo de Planejamento) que promoveu a contratação de consultoria para a elaboração do PUB (Plano Urbanístico Básico) em 1968. Apesar dos debates que suscitou não foi implantado. Através de financiamentos, governamentais principalmente, aumentou a verticalização, principalmente para classe média. A COHAB começou a construir conjuntos habitacionais na periferia, fora da área de estudo (ROLNIK, R. 1990 p.111).

Nos anos 60 o centro, segundo Cordeiro:

"... a economia de escala, que é uma curva de crescimento contínuo, deve ter atingido o ponto de inflexão em que o adensamento produz deseconomias, provocando a procura por novos espaços..." (CORDEIRO, H. 1980 p.59) Intensificou-se o afastamento de atividades de comércio e serviços do centro tradicional para a região da Paulista, que recebeu cinemas, hotéis, sedes de empresas e instituições financeiras (CORDEIRO, H. 1980 p.163)(MEYER, R. 1994 p.5).

Com a inauguração do Shopping Iguatemi na Avenida Brigadeiro Faria Lima em meados dos anos 60 nasceu mais um subcentro que cresceu rapidamente durante os anos 70 (MEYER, R. 1994 p.5)(CORDEIRO, H. 1980 p.163). Em 1970 o censo indicou pela primeira vez que a população urbana brasileira tinha se tornado maior do que a rural (MARTINS, M. 1980 p.47). 
Continuou também o incentivo governamental às atividades econômicas desenvolvidas em São Paulo. Afirma Rolnik:

"Verdadeira locomotiva do milagre econômico que se sucedeu ao golpe, São Paulo e sua região Metropolitana serão objeto de novos e intensos investimentos públicos, que darão suporte à modernização de alguns ramos industriais associados ao capital multinacional "(ROLNIK, R. 1990 p.77) No centro histórico na década de 70 começou a haver um decréscimo do número de empregos (VILLAÇA, F. 1978 p.285).

Nos anos 70 foi elaborado o PMDI (Plano Metropolitano de Desenvolvimento Integrado) e em 1971 o PDDI (Plano Diretor de Desenvolvimento Integrado) propondo principalmente a reorganização viária e o zoneamento, implantado em 1972 (MARCONDES, C. 1988 93,94,95).

Segundo Costa, muitas críticas foram feitas ao PDDI, como, por exemplo, a ênfase que ele deu à circulação do automóvel e ao caráter "elitista" da lei de zoneamento (COSTA, L. 1995 p.24). Entretanto, ele foi um dos planos que, embora parcialmente implantado, mais influenciou o desenvolvimento da cidade.

A partir de 1976 a Prefeitura reurbanizou a região central através dos calçadões (PORTO, A. 1992 p.180). Nos anos 70 também o metrô reorganizou as atividades e deslocamentos na cidade. O metrô, segundo Cordeiro, reforçou o papel do centro "como foco da rede de transportes e do fluxo de tráfego" (CORDEIRO, H. 1980 p.172, 173).

Em meados da década de 70, a desconcentração industrial tomou impulso maior. Por outro lado São Paulo continuou a atrair cada vez mais o setor financeiro. Além disso no final dos anos 70 intensificaram-se as reivindicações 
pela redemocratização (ROLNIK, R. 1997 p.207)(SÃO PAULO (PMSP/SERA) 1992 p.94).

No final dos anos 70 com a crise econômica, a elevação do custo da terra frente à diminuição da renda da população mais carente e o conseqüente encarecimento dos lotes populares na periferia aumentou o número de favelas e cortiços (COSTA, L. 1995 p.55).

Concluindo, nesse período, a área de estudo sofreu ainda a instalação de novos usos que completaram sua área urbanizada, como instalação de loteamentos residenciais de elite principalmente na região sudoeste, como Jardim América, Jardim Europa, Alto da Lapa, Bela Aliança, Alto de Pinheiros, Pacaembú e Jardim Luzitânea. Bairros de classe média instalaram-se principalmente próximos aos bairros de elite. Todos as regiões residenciais sua ocupação intensificada. A indústria completou sua ocupação nas áreas próximas às ferrovias e, posteriormente, nas regiões favorecidas por rodovias como, por exemplo, a Vila Leopoldina.

As transformações no uso do solo também foram intensas. Nesse período também teve início a verticalização no centro, primeiramente com edifícios destinados ao uso de comércio e serviços, na década de 20 no Triângulo principalmente. Nos anos 30, iniciou-se, ainda que de forma incipiente a verticalização para uso residencial, no Centro e regiões residenciais (inclusive de elite) próximas a ele como Campos Elíseos, Higienópolis, Santa Cecília, Santa Efigenia, Vila Buarque e na Av. Paulista. Essa verticalização se intensificou posteriormente, chegando a atingir até mesmo áreas do Paraíso, Jardim Paulista, Perdizes, Cerqueira César, etc... Nos anos 70 essas regiões tiveram sua verticalização intensificada e novos bairros, localizados 
principalmente na região sul e sudeste começaram a se verticalizar como Pinheiros, Itaim, Moema, Vila Madalena, Indianópolis, Itaim.

O Brás, Lapa e Pinheiros se consolidaram como subcentros populares de comércio e serviço expandindo-se sobre as quadras residenciais vizinhas. O comércio de elite Triângulo se expandiu para áreas adjacentes e para a Cidade Nova e posteriormente abandonou o centro tradicional para se instalar na região da Avenida Paulista e Jardins, abrindo espaço para a instalação do comércio popular na região desse centro tradicional. A avenida Paulista se firmou como novo subcentro, sobretudo da elite e nos anos 70 a avenida Faria Lima começou a emergir como novo subcentro comercial e de serviços. 


\section{4 - PERÍODO DE SERVIÇOS}

No início dos anos 80 agravou-se a crise econômica brasileira devido à nova situação internacional (ROLNIK, R. 1990 p.20) (SÃO PAULO (PMSP/SERA) 1992 p. 110).

Afirma Rolnik:

"Por ora, o que vale reter é que a crise de 1980-1984 provocou um ajustamento estrutural da economia brasileira. De país receptor líquido de divisas, o Brasil passa a exportador. Isso acaba afetando o padrão de investimento, que despenca do nível de $22 \%$ na década de 70 para modestos 17\% nos 10 anos seguintes. Além disso, para remeter divisas, torna-se necessário reduzir as importações, e a indústria de transformação passa a liderar as exportações, com saldos sempre positivos a partir de então. Iniciase, neste momento, o esgotamento do processo substitutivo de importações, que afetará a dinâmica econômica nacionais...” " A acomodação produtiva da década de 80 decorre exatamente do esgotamento deste modelo técnicoindustrial gerado pelo processo substitutivo de importações, que se baseou muito mais na complementação do parque industrial - protegido da competição externa e dominado internamento por cartéis - do que na sua dinamização para competir" (ROLNIK, R. 1990 p.90)

Com isso, as taxas de inflação começaram a subir e a gerar um empobrecimento da população com a estagnação da renda per-capta e a decadência dos serviços públicos (SINGER IN ROLNIK, R. 1990 p.9)(SÃO PAULO (PMSP/SERA) 1992 p.110).

Todas essas alterações na estrutura socioeconômica se refletiram na cidade. Segundo Rolnik há uma "revisão do padrão periférico de crescimento" que 
tinha sido o padrão de crescimento urbano dominante nas décadas anteriores, com o empobrecimento de áreas mais centrais, principalmente através do grande aumento de favelas e cortiços, além do aumento de densidade, tanto no centro como na periferia da cidade (ROLNIK, 1990 p.13,15,53).

Aumentou o problema da segurança pública e proliferam os condomínios fechados (ROLNIK, R. 1990 p. 4,13 e 15). O desemprego aumentou e camelôs e ambulantes se instalaram principalmente no centro e subcentros comerciais (LEMOS, C. 1998 p.34).

São Paulo assistiu a um êxodo industrial, mas também, a um aumento do comércio/serviços sofisticados e shoppings, resultando em uma polinucleação (ROLNIK, R. 1990 p.143,149). Um exemplo é a avenida Berrini (fora da área de estudo) que, segundo Cordeiro, tornou-se um subcentro de comércio e serviços rivalizando com a Avenida Faria Lima e a Paulista devido a sua proximidade aos bairros de elite do Morumbí (CORDEIRO, H. 1980 p.18). A ocupação desordenada da cidade também fez com que aumentassem os problemas ambientais, como enchentes, deslizamentos, poluição do ar e dos mananciais (fora da área de estudo), ocupados cada vez mais de forma irregular (ROLNIK, R. 1990 p.14).

No final dos anos 80, com chamada globalização, São Paulo se destacou como cidade mundial, uma metrópole de serviços, principalmente na área médica e educacional (ROLNIK, R. 1990 p.24).

No período analisado foi elaborada uma série de novos Planos Diretores para a cidade por parte da Administração Municipal. Segundo Costa, inúmeros foram os motivos para que não fossem aprovados ou implementados como, por exemplo, a descontinuidade administrativa, dificuldades políticas com as 
Câmaras de Vereadores e dentro da própria Prefeitura, inviabilidade das propostas perante a sua capacidade financeira (COSTA, L. 1995 p.89,101,167).

A crise econômica, além de atingir a população mais carente e aumentar a demanda social, também atingiu o setor imobiliário, que procurou reivindicar junto aos poderes públicos incentivos para suas atividades (COSTA, L. 1995 p.143,150).

No final da década de 90 tornou-se evidente a dificuldade por parte da Administração Pública em fiscalizar o cumprimento da lei de Zoneamento, sendo que inúmeras irregularidades foram sendo trazidas ao conhecimento público, principalmente nas $\mathrm{Z1}$, zonas estritamente residenciais. Concluindo, nesse período toda área de estudo já estava urbanizada, ocorrendo, portanto, principalmente substituições de usos. As transformações de uso do solo embrionárias ainda na da década de 70 tornaram-se evidentes nesse período.

Outros subcentros nasceram ou se consolidaram, principalmente na região sudoeste da cidade como a Avenida Faria Lima, trecho da Avenida Marginal Pinheiros e Avenida Berrini (fora da área de estudo). Espalharam-se os shoppings centers pela cidade. Houve um aumento generalizado de apartamentos, de comércio e serviços, consolidando o cento expandido. As áreas residenciais de elite tem sofrido cada vez mais pressão para instalação de novos usos, com resistência de seus moradores, que organizados em associações, vem solicitando embargos na justiça, bolsões residenciais e o tombamento de seus bairros. Com a saída das indústrias as antigas áreas industriais começaram a sofrer um aumento de outros usos, principalmente 
comercial e de serviços.

O centro histórico também sofreu as conseqüências da crise econômica; ruas e praças estão sendo ocupadas por sem-teto e vendedores ambulantes vítimas da exclusão social. Os índices de violência também aumentaram e são amplamente divulgados pelos meios de comunicação, revelando a imagem do centro histórico como uma região perigosa e deteriorada.

Nos anos 90 surgiram também tentativas de revitalização da região. É criada a Associação Viva o Centro, uma organização não governamental voltada para a discussão e apresentação de solução para as questões do centro. A própria administração municipal mudou-se para as imediações do Parque Dom Pedro e criou projetos específicos de incentivo e revitalização do centro, como o PROCENTRO. Edifícios antigos de valor histórico foram restaurados com recursos públicos ou de empresas privadas como, por exemplo, o Teatro Municipal, o edifício dos Correios, a antiga estação ferroviária Júlio Prestes (que se transformou em sala de concertos musicais) e o antigo edifício construído pela Light que se tornou um Shopping Center. Movimentos sociais organizados reivindicam a ocupação de edifícios vagos com moradia popular. 


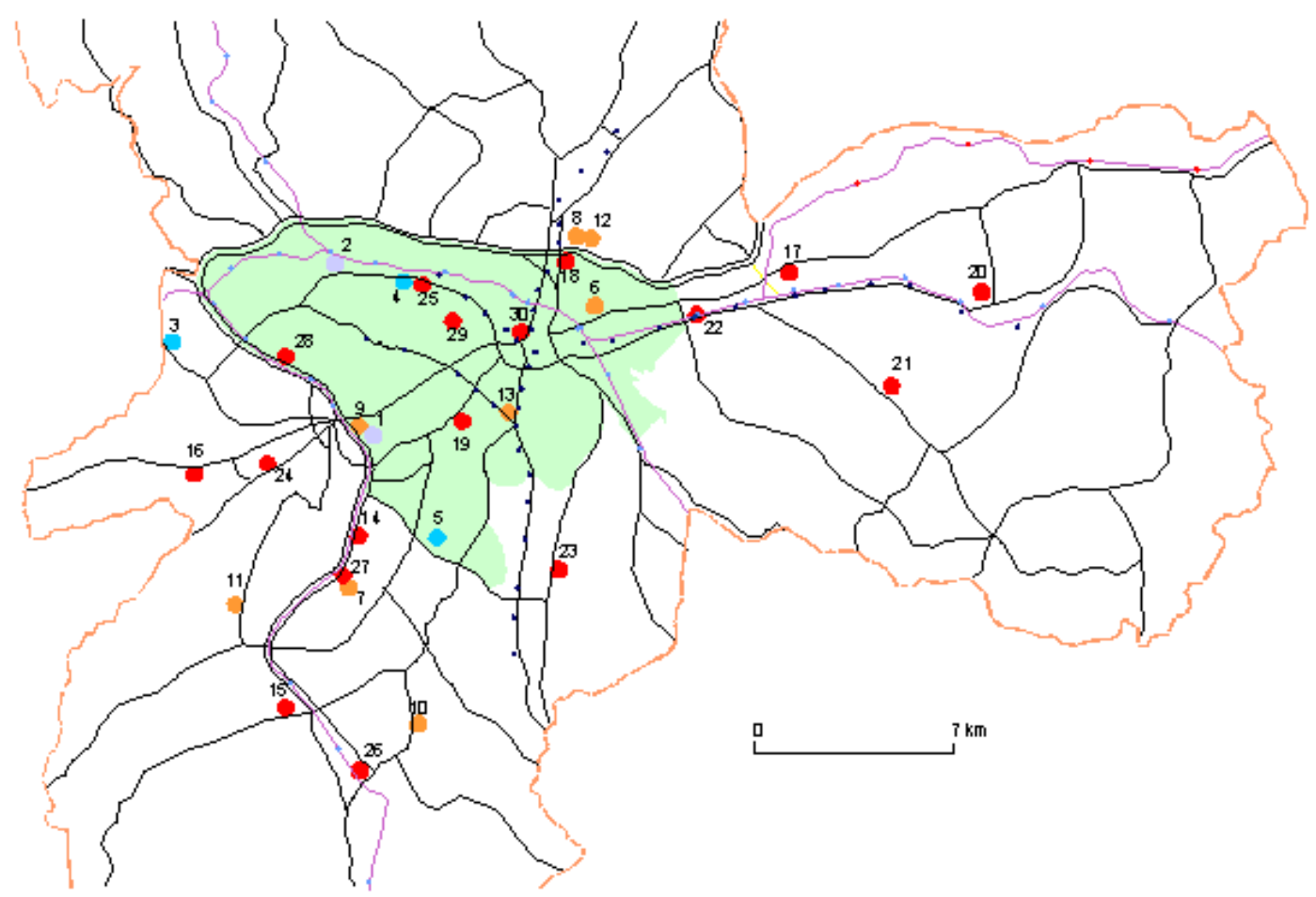

PRINCIPASS SHOPPINGS *DO MUNICÍPIO DE SÄO PAJULO EM 2000

área de estudo

shoppings inaugurados na década de 60

shoppings inaugurados na década de 70

shoppings inaugurados na década de 80

shoppings inaugurados na década de 90

- vias principais segundo guia Mapograf 1997

- estaọ̄es de metrö segundo guia M apograf 1997

- estaộ̃es de trem segundo guia Mapograf 1997

* Foram considerados shoppings os em preendimentos comerciais assim denominados pela PMSP (Prefeitura do Município de S. P aulo) com área construída superior a $10.000 \mathrm{~m} 2$ e núm ero de lojas superior a 120

Denominaçäo dos principais shoppings:

1-Iguatem i, 2-Lapa, 3-Continental, 4- Bourbon, 5- Ibirapuera, 6- Fashion Brás, 7-M orumbi, 8- Norte, 9- Eldorado, 10- Intrlagos, 11- Jardim Sul, 12- Lar Center,

13- Paulista, 14-D \&D, 15- Fiesta, 16- Off P rice Raposo, 17Penha, 18- D.

19-Eldorado Pamplona, 20-Leste, 21 -Leste Aricanduva, 22-Metrố Tatuapé,

23- Plaza Sul, 24- Butantấ, 25- We ș Plaza, 26-SP Market, 27 SP Market Place

28- Villa Lobos, 29- $P$ átio Higienópolis, 30- Light 


\section{CAPÍTULO 3 - LEGISLAÇÃO RESTRITIVA ÀS TRANSFORMAÇÕES NO USO DO SOLO RESIDENCIAL}

Como vimos no capítulo anterior, a preocupação em controlar, através da legislação oficial, a transformação do uso do solo residencial para outros usos surgiu principalmente a partir da década de 30, embora já existisse legislação de 1916 proibindo o uso industrial na avenida Paulista.

Pelo Ato 663 de 10 de agosto de 1934, entre outras coisas, a cidade foi dividida em quatro zonas: central, urbana, suburbana e rural, havendo a restrição à instalação de determinados usos em algumas áreas. $O$ artigo 40 do mesmo ato garantiu à algumas ruas e bairros a exclusividade para uso residencial, permitindo comércio local apenas sob condições especiais, tais como distância mínima entre os pequenos núcleos comerciais e aprovação dos moradores. A lei 3571/37 também determinava a exclusividade residencial, mas permitindo o uso residencial vertical. $O$ artigo 40 do ato 663/34 e a lei $3571 / 37$ foram os principais instrumentos para restringir as transformações no uso do solo residencial até a década de 70 , e inúmeras leis e decretos foram criados ampliando ou revogando sua área de abrangência. Em 1954 nas áreas a que se referia a lei $3571 / 37$ foi permitido comércio de caráter local . Na década de 50 foi elaborada a legislação de ruídos, que pela primeira vez dividiu a cidade em categorias de uso (estritamente residenciais, predominantemente residenciais, industriais, etc.), contudo, essa legislação apenas procurava restringir a poluição sonora, não controlando as 
transformações do uso do solo como o artigo 40 do Ato 663/34 ou a lei 3571/37 (MARCONDES, C. 1988 p.68).

Em 1972, pela primeira vez, foi aprovado o zoneamento para toda a cidade, com restrições mais severas à instalação de novos usos para as áreas estritamente residenciais. Ele foi sendo modificado ao longo dos anos, com a criação, inclusive, de corredores comerciais em áreas estritamente residenciais (COSTA, L. 1995 p.24).

Nas tabelas e mapas que se seguem podemos ver os bairros e os respectivos números e perímetros da legislação, segundo cortes temporais compatíveis com os mapas de uso do solo, que serão apresentados no capítulo seguinte. 


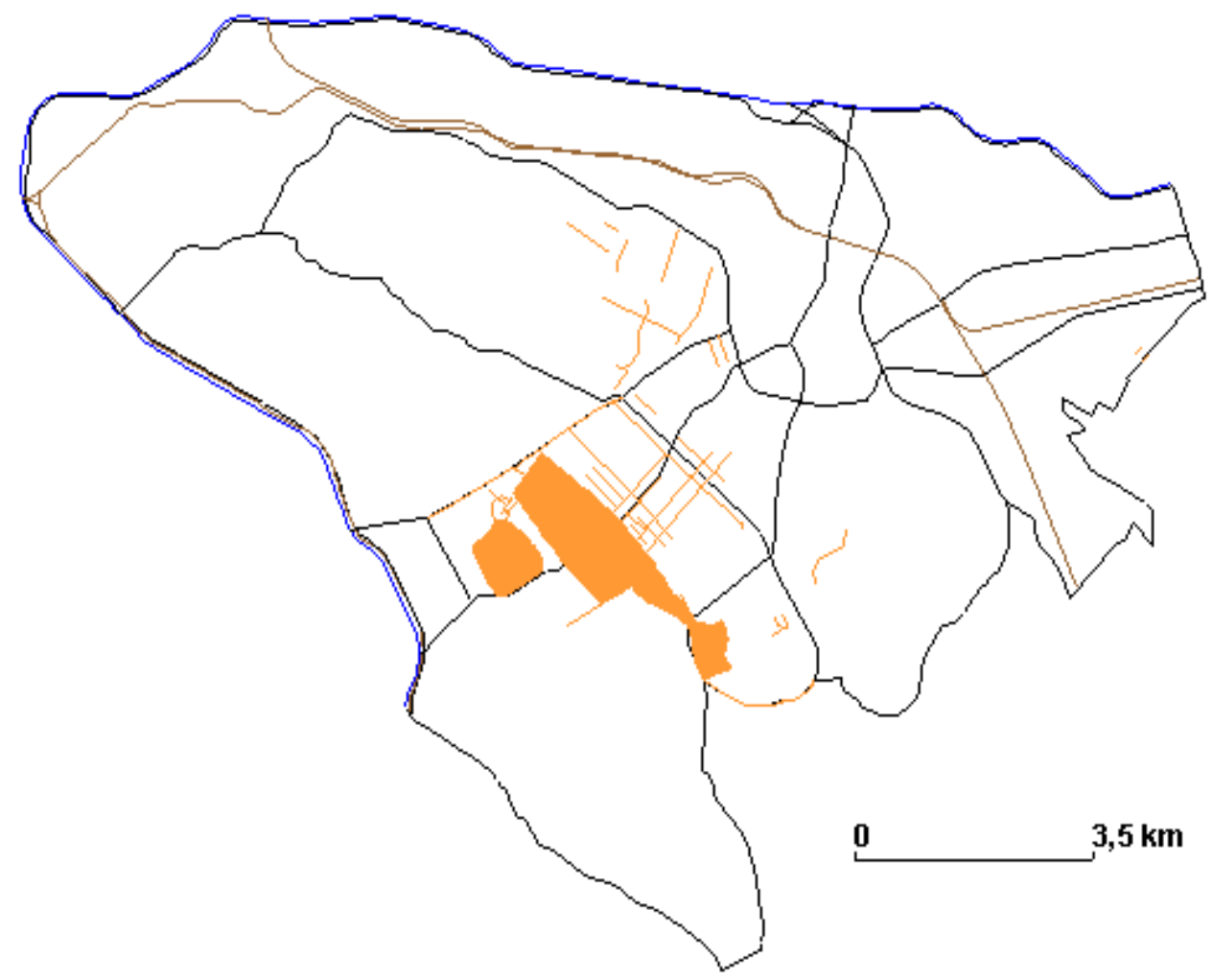

\section{ÁREAS ESTRITAMENTE RESIDENCIAIS}

CRIADAS ENTRE 1922-1951

PARA VER DATA DE REVOGAÇÃO E EXCEÇÕES, COMO NÚCLEOS E CORREDORES COMERCIAIS PERMITIDOS CONSULTAR ÍNTEGRA DA LEGISLAÇÃO 


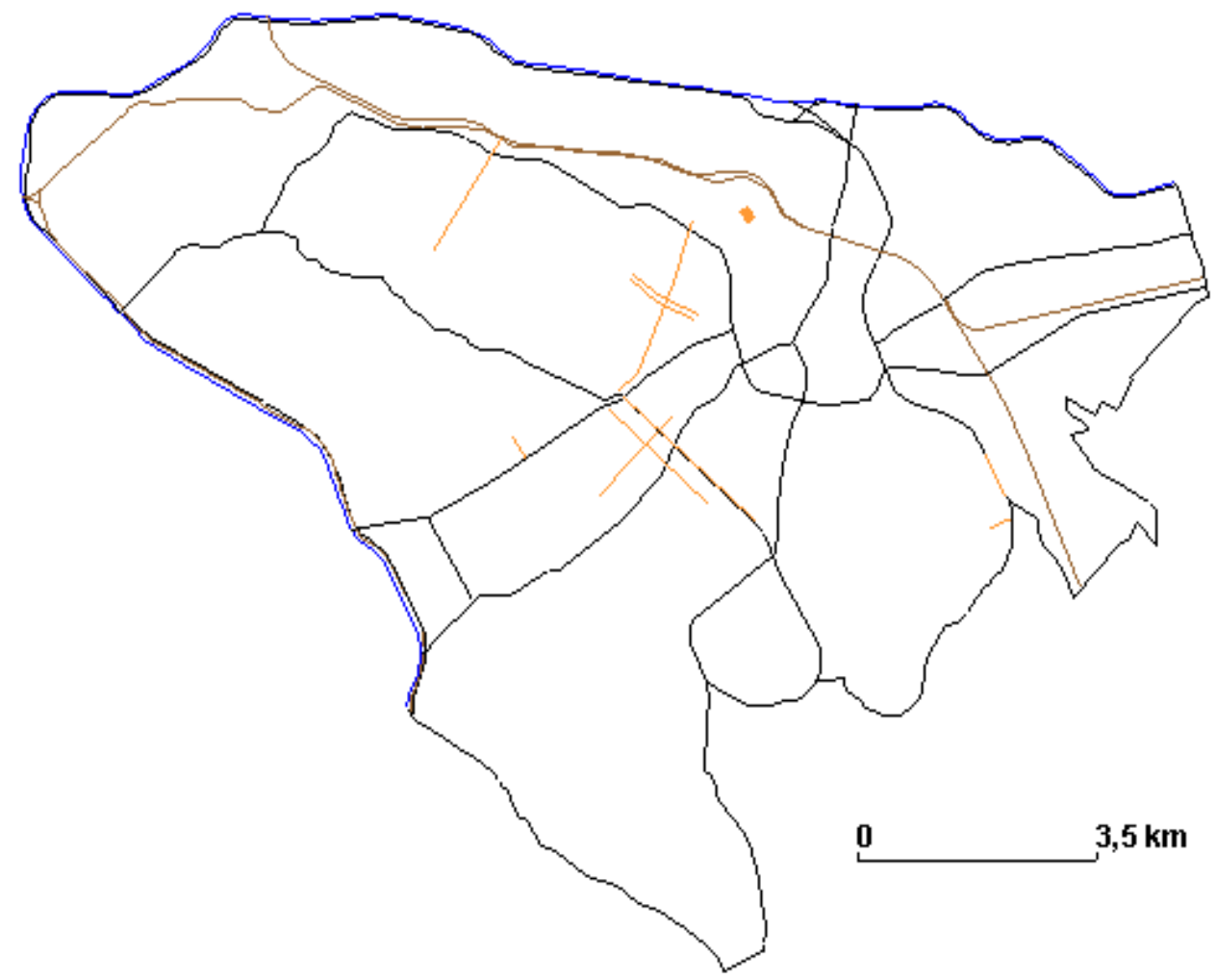

ÁREAS ESTRITAMENTE RESIDENCIAIS (APTO PERMITIDO)

CRIADAS ENTRE 1922-1951

PARA VER DATA DE REVOGAÇÃO E EXCEÇÕES, COMO NÚCLEOS E CORREDORES COMERCIAIS PERMITIDOS CONSULTAR ÍNTEGRA DA LEGISLAÇÃO 


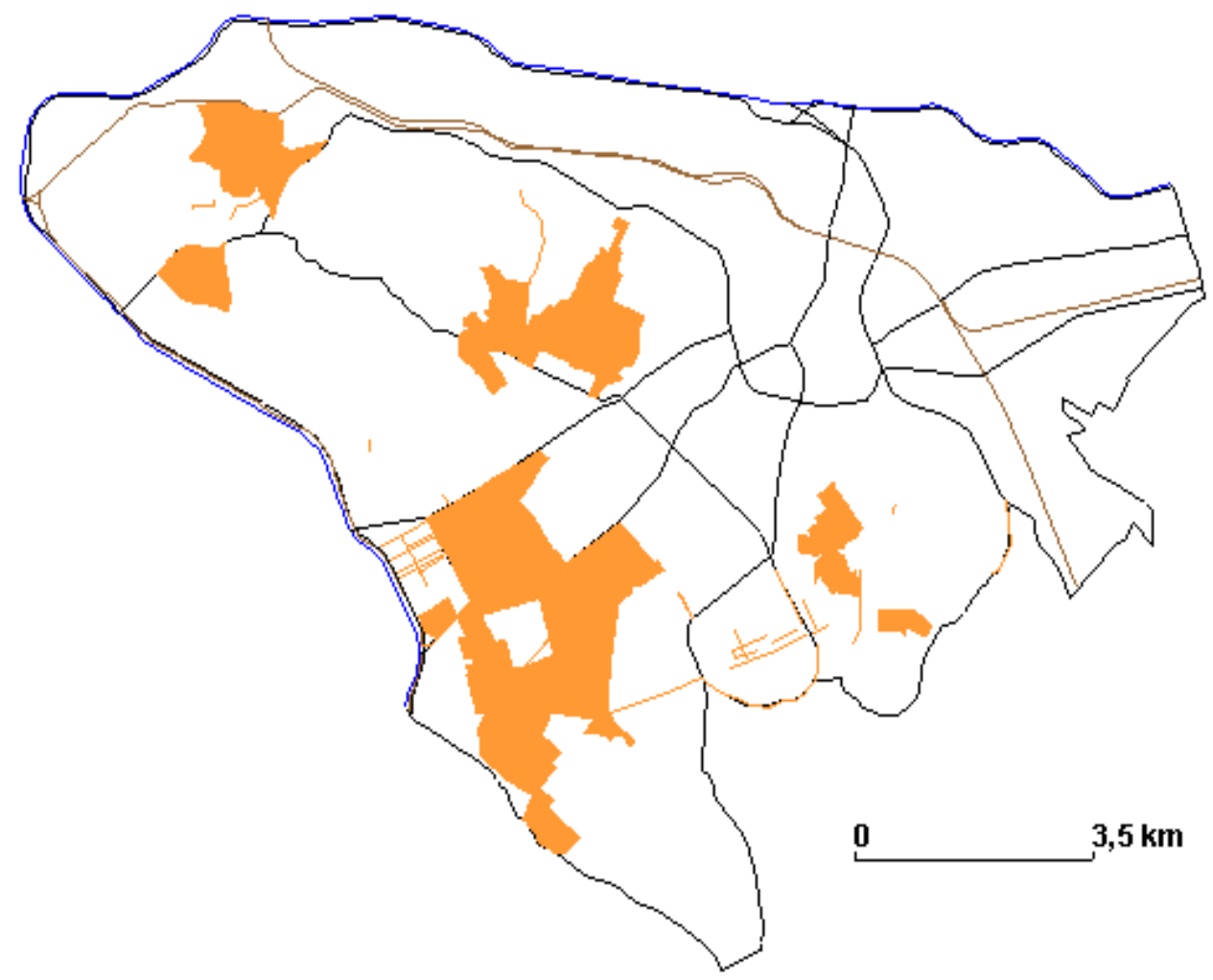

\section{ÁREAS ESTRITAMENTE RESIDENCIAIS}

CRIADAS ENTRE 1952-1972

PARA VER DATA DE REVOGAÇÃO E EXCEÇÕES, COMO NÚCLEOS E CORREDORES COMERCIAIS PERMITIDOS CONSULTAR ÍNTEGRA DA LEGISLAÇÃO 


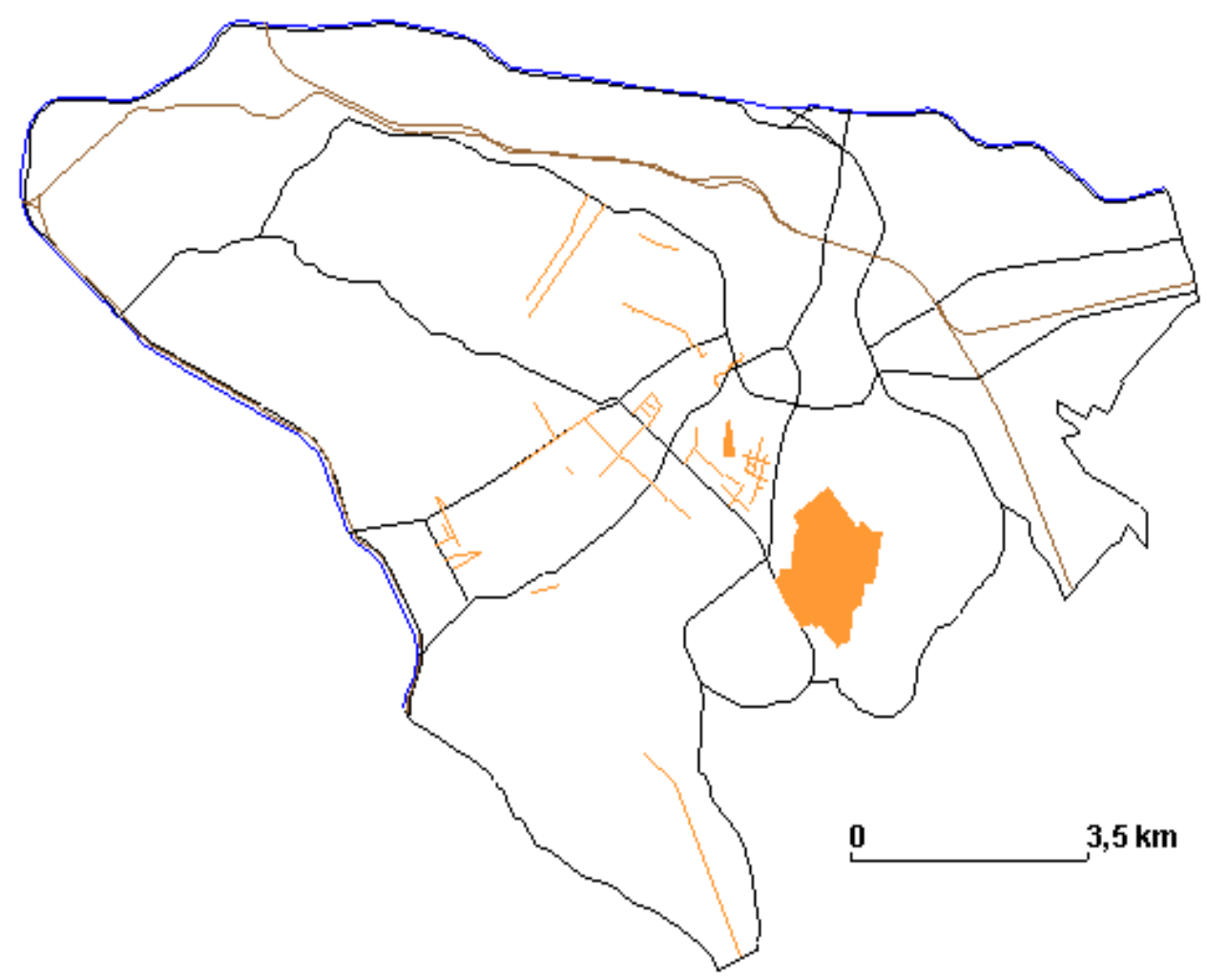

ÁREAS ESTRITAMENTE RESIDENCIAIS (APTO PERMITIDO)

CRIADAS ENTRE 1952-1972

PARA VER DATA DE REVOGAÇÃO E EXCEÇÕES, COMO NÚCLEOS E CORREDORES COMERCIAIS PERMITIDOS CONSULTAR ÍNTEGRA DA LEGISLAÇÃO 


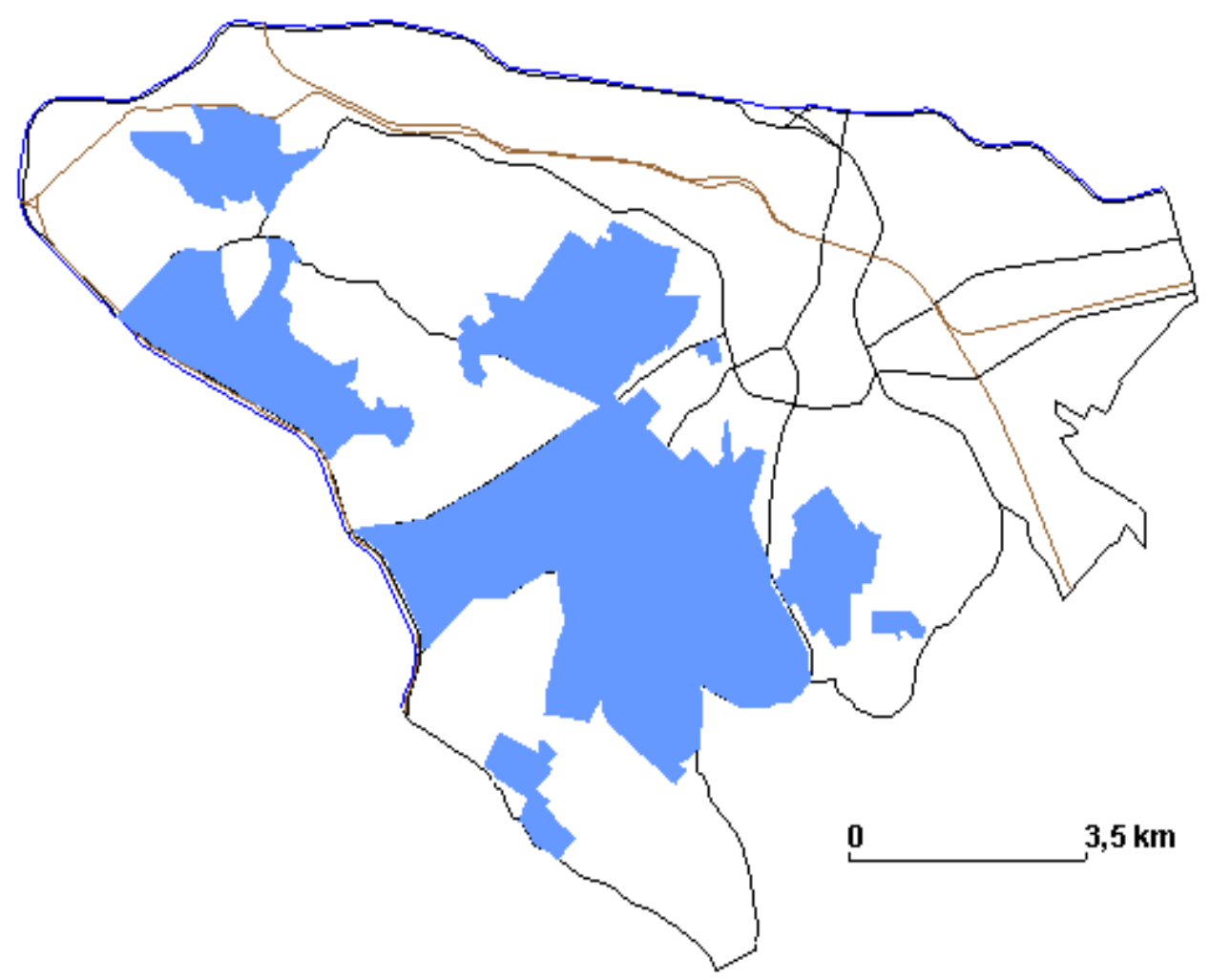

\section{ÁREAS ESTRITAMENTE RESIDENCIAIS}

LEI DE RUÍDOS (L4505/55 E D 3962/58)

PARA VER DATA DE REVOGAÇÃO E EXCEÇÕES, COMO NÚCLEOS E CORREDORES COMERCIAIS PERMITIDOS CONSULTAR ÍNTEGRA DA LEGISLAÇÃO 


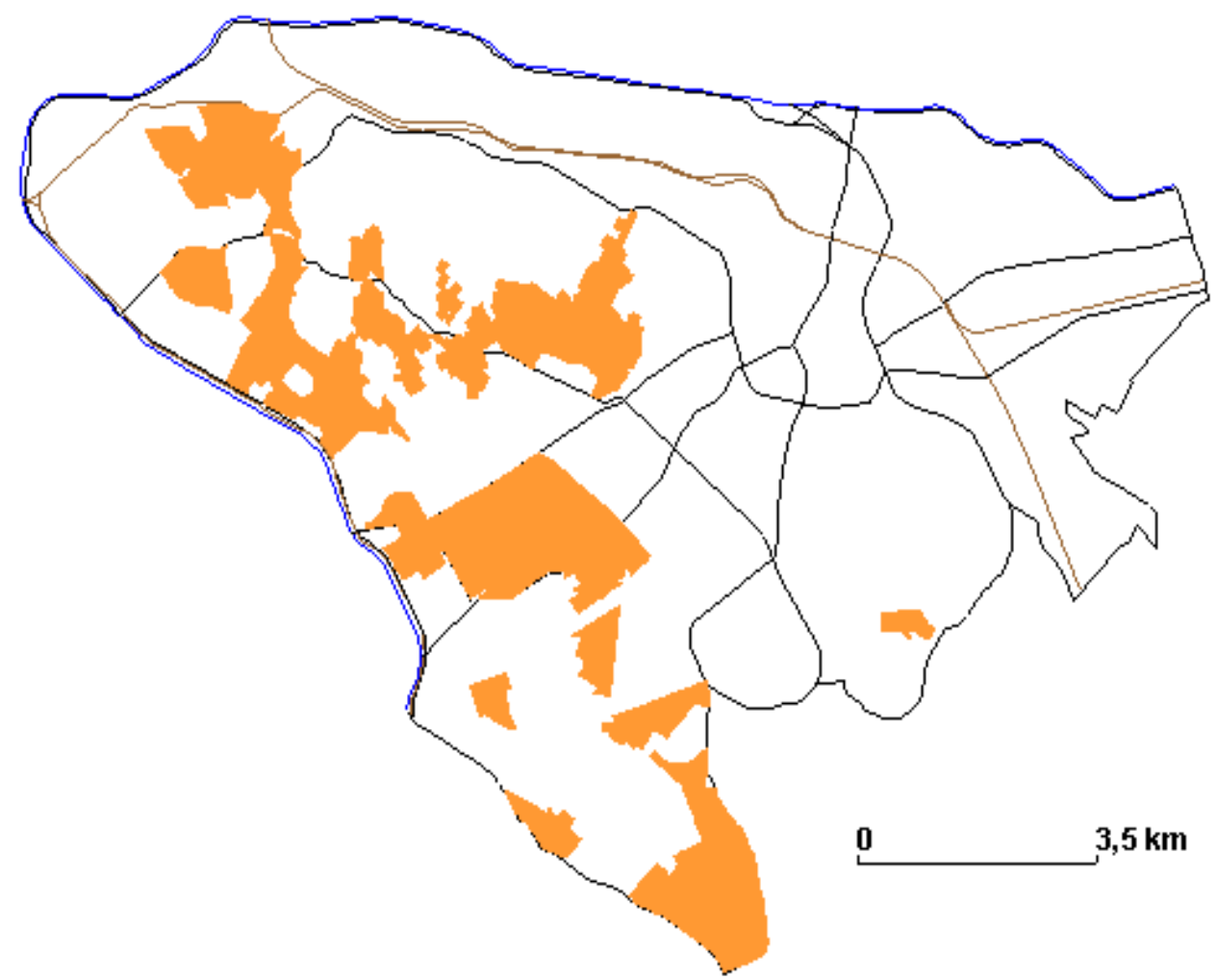

\section{ÁREAS ESTRITAMENTE RESIDENCIAIS}

CRIADAS EM 1972

PARA VER DATA DE REVOGAÇÃO E EXCEÇÕES, COMO NÚCLEOS E CORREDORES COMERCIAIS PERMITIDOS CONSULTAR ÍNTEGRA DA LEGISLAÇÃO 


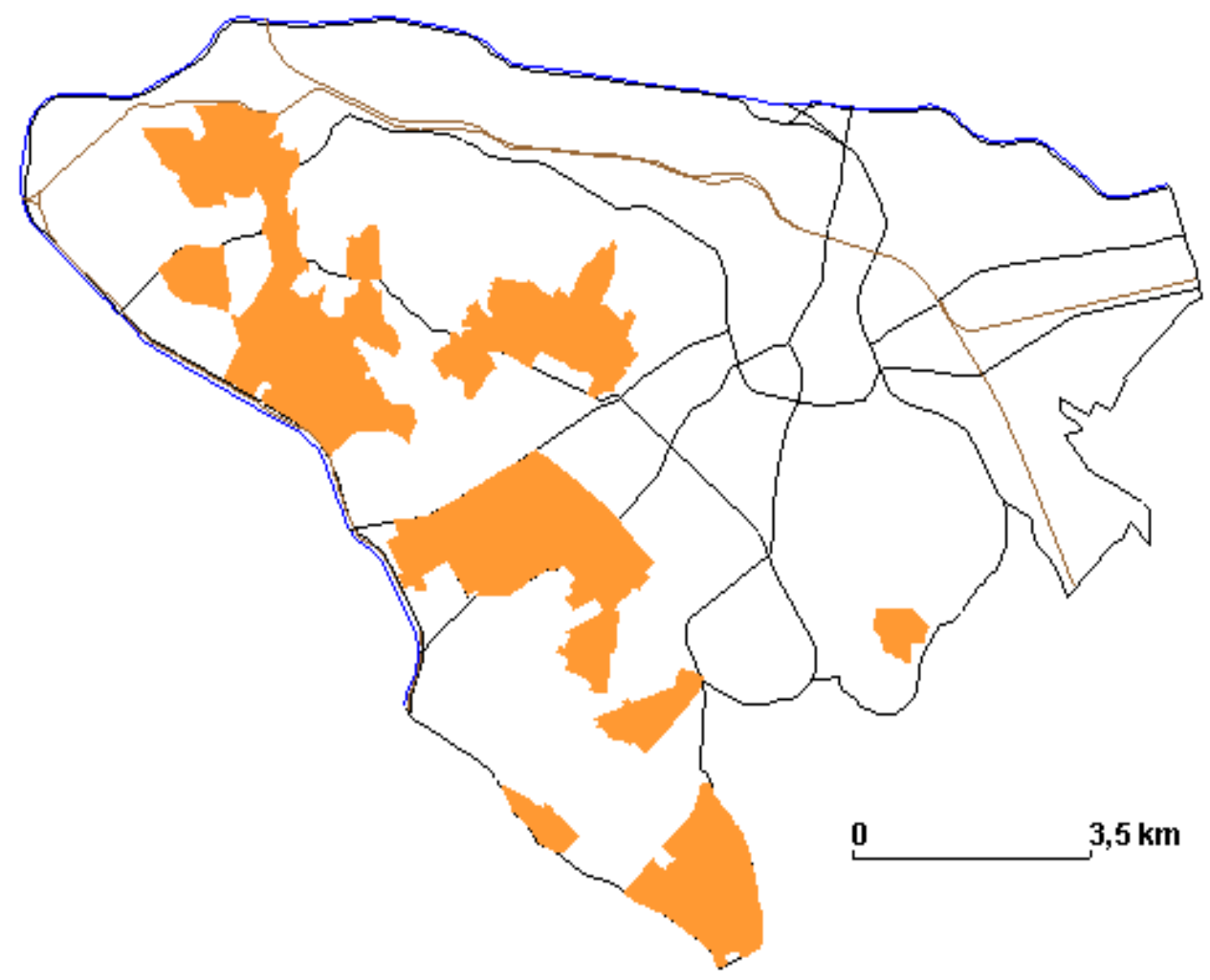

\section{ÁREAS ESTRITAMENTE RESIDENCIAIS}

VIGENTES EM 1999

PARA VER DATA DE REVOGAÇÃO E EXCEÇÕES, COMO NÚCLEOS E CORREDORES COMERCIAIS PERMITIDOS CONSULTAR ÍNTEGRA DA LEGISLAÇÃO 


\section{CAPÍTULO 4 - DINÂMICA DAS TRANSFORMAÇÕES}

\section{1 - A EVOLUÇÃO LOCAL - BAIRROS}

As tabelas que se seguem nos mostram a evolução do uso do solo por bairros, em ordem alfabética.

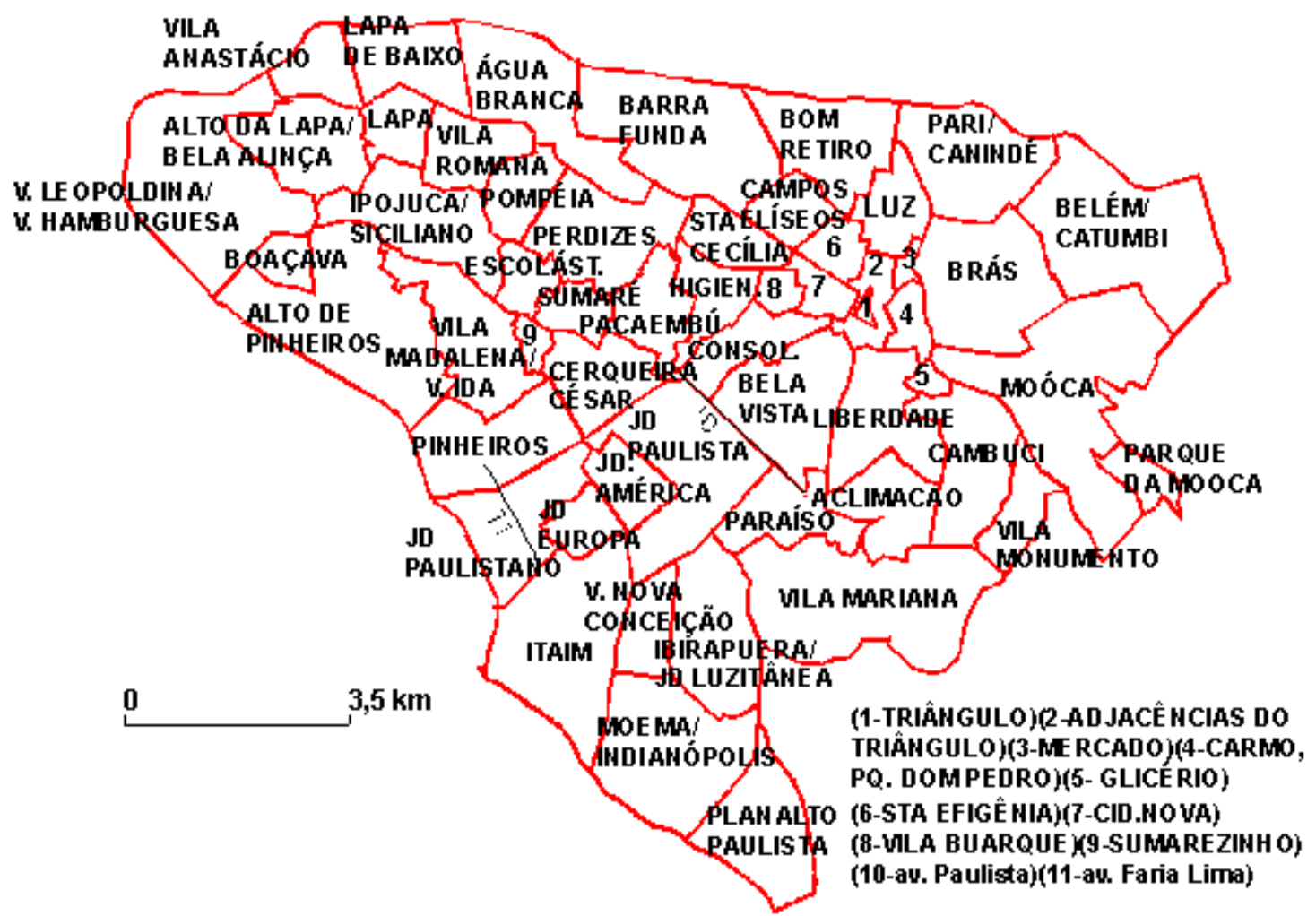

Perímetro dos bairros 


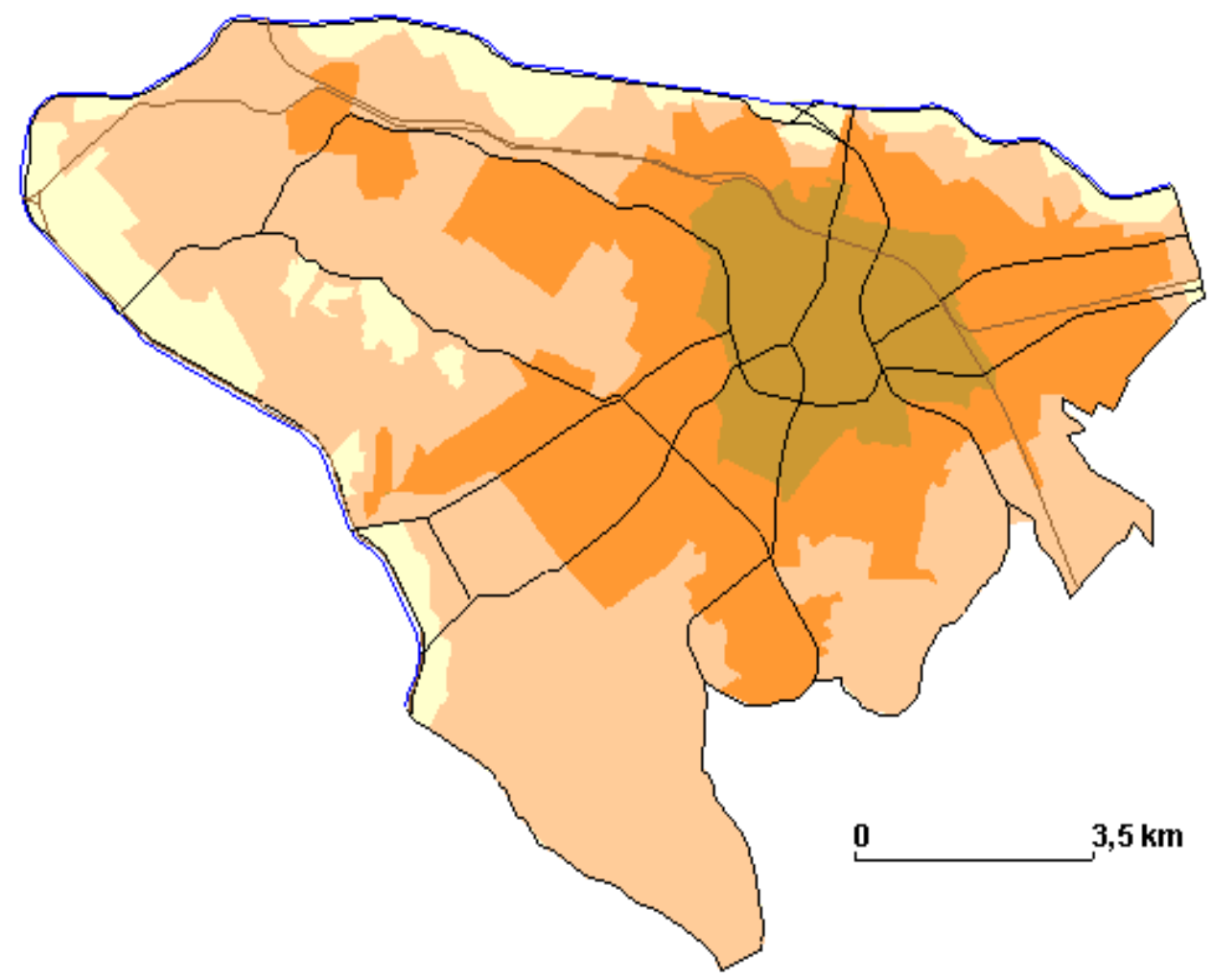

ÁREA URBANIZADA

ATÉ 1890

1891-1922

1923-1952

APÓS 1952

Fontes: (AZEVEDO, A. 1958)(HOMEM, M. 1980)(SÃO PAULO (PSMP) 1922) 


\section{ACLIMAÇÃO}

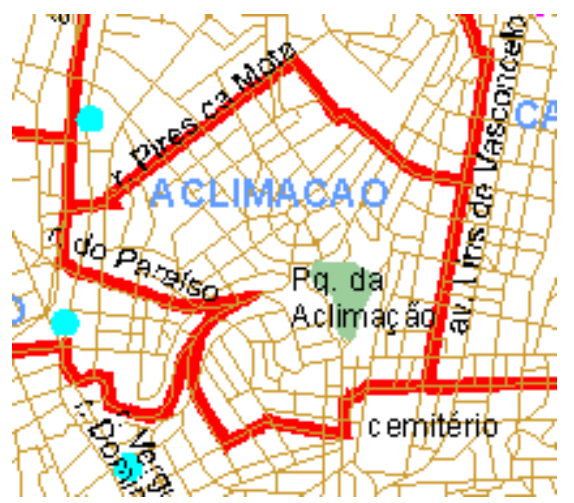

\section{ANTERIOR A 1890}

\section{0-1921}

O bairro da Aclimação surgiu após 1892, ano da inauguração do Jardim da Aclimação, que, rapidamente se tornou importante local de lazer da população da cidade (DOREA, A. 1982 p.45)(PONCIANO, L. 1999 p.33).

\section{2-1951}

Até a década de 30 a região continuou a ser loteada e ocupada pelo uso residencial horizontal de classe média. Nos anos 30 até mesmo parte da área do Jardim foi loteada (DOREA, A. 1982 p.87). Em 1939 a Prefeitura comprou o Jardim para transforma-lo em parque (PONCIANO, L. 1999 p.33).

1952-1971

A partir dos anos 50 inicia-se a verticalização residencial do bairro (SOMEKH, N. 1989 p.84)(TARALLI, C. 1993 p.168)(MENDES, R. 1958 p.265). 1972-1999

A partir da década de 70 continuou o crescimento do uso residencial vertical para classe média com aumento de uso comercial e de serviços (SOMEKH, N. 1989 p.103)(TARALLI, C. 1993 p.168)(DOREA, A. 1982 p.14)(PMSP/SEMPLA v.1 p.29). 


\section{ÁGUA BRANCA}

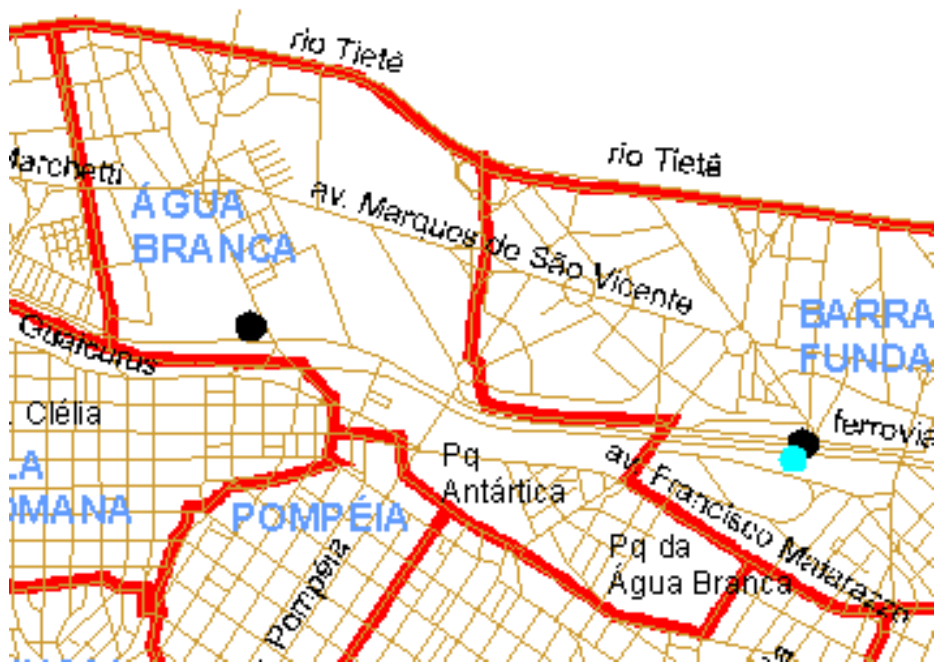

\section{ANTERIOR A 1890}

\section{0-1921}

Desde a última década do século XIX foi um bairro residencial horizontal operário e industrial, com a presença de cortiços na área próxima à ferrovia (HOMEM, M. 1980 p.25)(SEGATTO, J. 1988 p.32)(TORRES, M. 1969 p.167)(ROLNIK, R. 1997 p.78). Segundo Villaça havia também um conjunto de residências de bom padrão próximo ao Parque Fernando Costa (antigo Parque da Água Branca)(VILLAÇA, F. 1998 p.195).

\section{2-1951}

Nesse período, principalmente após década de 30, ocorreu uma intensificação da ocupação industrial (LOBO JR, M. 1986 p.63). Ocorreu também até 1940 um processo de afastamento de moradores das casas de bom padrão para outros bairros (VILLAÇA, F. 1998 p.263).

\section{2-1971}

Para Mendes, no começo dos anos 50, próximo ao Parque Antártica e ao atual Parque Fernando Costa (Água Branca), havia uso residencial horizontal de classe média (MENDES, R. 1958 p.347), com a presença de alguns apartamentos, além da área industrial e residencial operária próxima à várzea (MENDES, R. 1958 p.348). Dados do TPCL da década de 70 mostravam a intensificação do uso residencial vertical na área próxima ao Parque Antártica e atual Parque Fernando Costa (CESAD/FAUUSP/PMSP, TPCL 1971).

\section{2-1999}

Segundo Andrade nesse período ocorreu diminuição do uso industrial e aumento do uso comercial/serviços em todo o bairro (PMSP 2000 mapa uso do solo)(ANDRADE, M. 1994 p.97). 


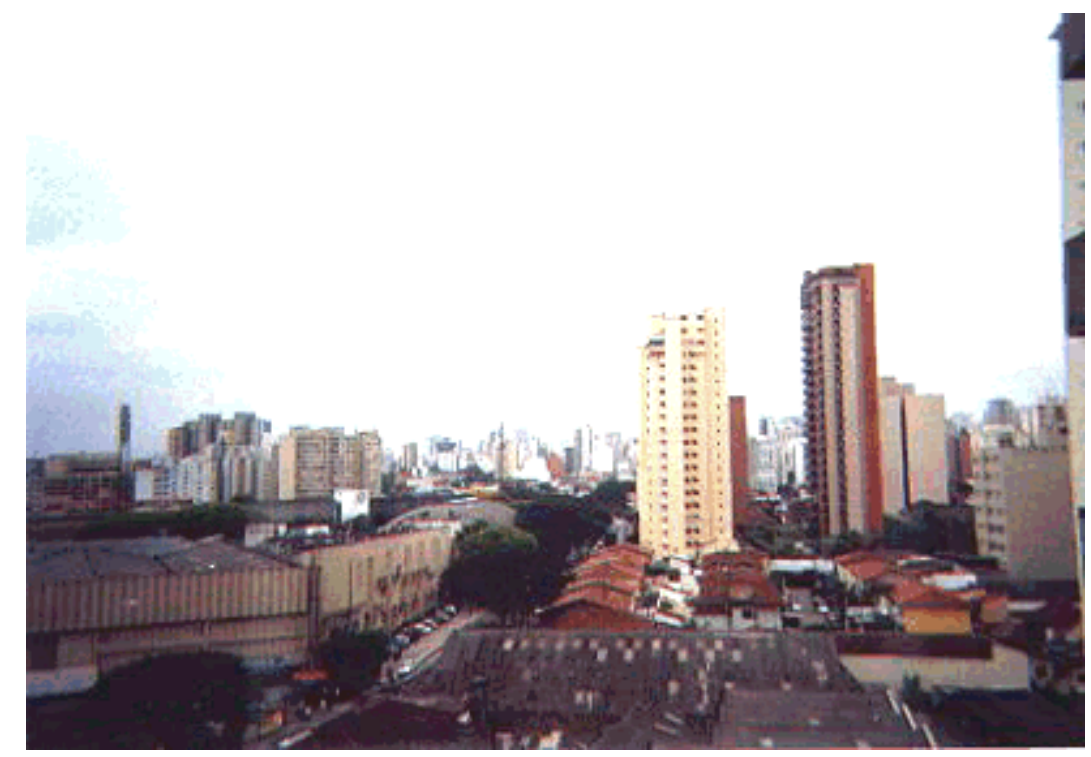

Água Branca em 1999 


\section{ALTO DA LAPA / BELA ALIANÇA}

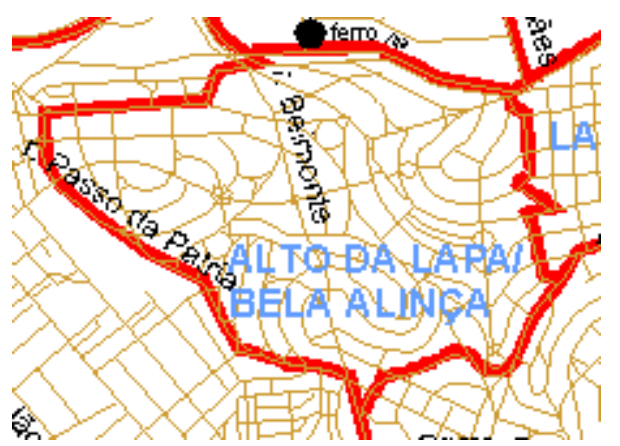

\section{ANTERIOR A 1890}

1890-1921

1922-1951

Alto da Lapa e Bela Aliança foram loteados na década de 20 pela Cia City como bairros residenciais horizontais de elite (PONCIANO, L 1999

p.35)(HOMEM, M. 1980 p.146)(SEGATTO, J. 1988 p.21)(SANTOS, W. 1980 p.65).

\section{2-1971}

Manteve sua ocupação de bairro residencial de elite (MENDES, R. 1958 p.357).

1972-1999

Manteve sua ocupação de bairro residencial de elite com corredores (PMSP 2000, mapa uso do solo 1999)(PMSP 2000 v.1 p.44). Há polêmica entre os moradores a respeito da permissão para instalação de novos usos no bairro residencial (GARBIN, L. 14/04/99 ESP). 


\section{ALTO DE PINHEIROS}

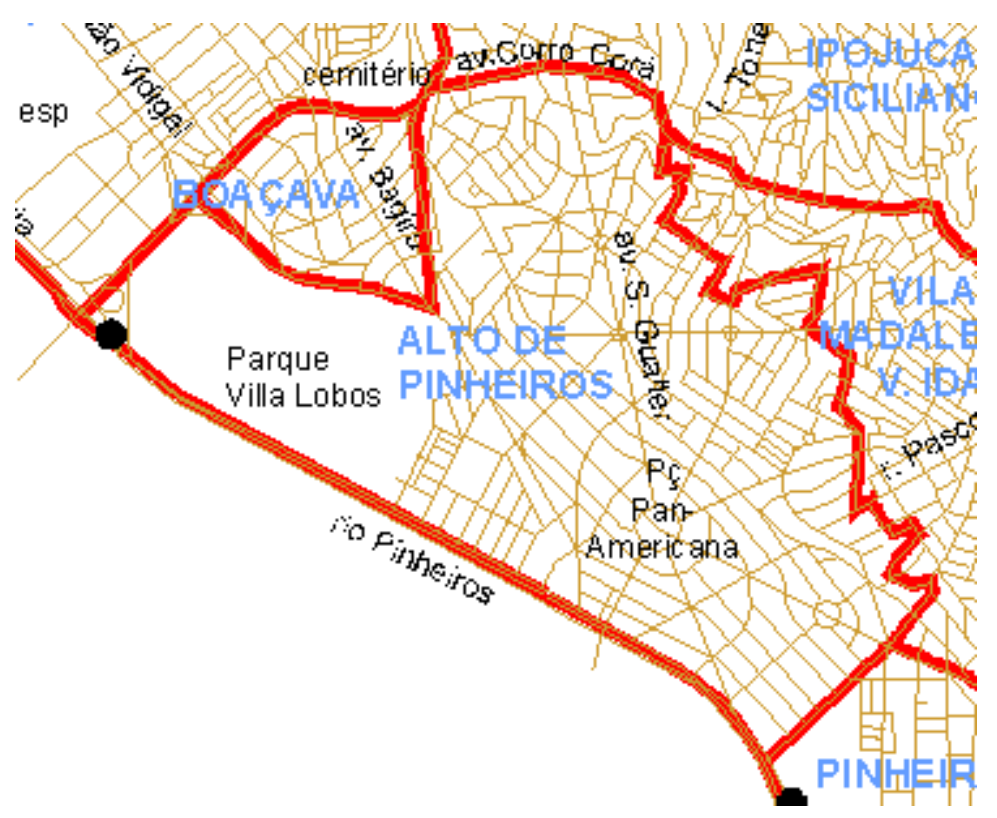

\section{ANTERIOR A 1890}

1890-1921

\section{2-1951}

A parte principal do bairro foi loteada na década de 30 como bairro residencial horizontal de elite (REALE, E. 1982 p.96).

\section{2-1971}

Até os anos 60 o bairro ainda se encontrava rarefeito (PETRONE, P. 1963 p.63).

\section{2-1999}

Manteve sua condição de bairro residencial horizontal de leite com corredores e algumas áreas com construção de apartamentos de bom padrão próximas ao Parque Villa Lobos e ao bairro do Boaçava, em antigas regiões sem ocupação ou de ocupação residencial de classe média (PMSP 2000 mapa uso do solo 1999)(PMSP 2000 v.1 p.44).

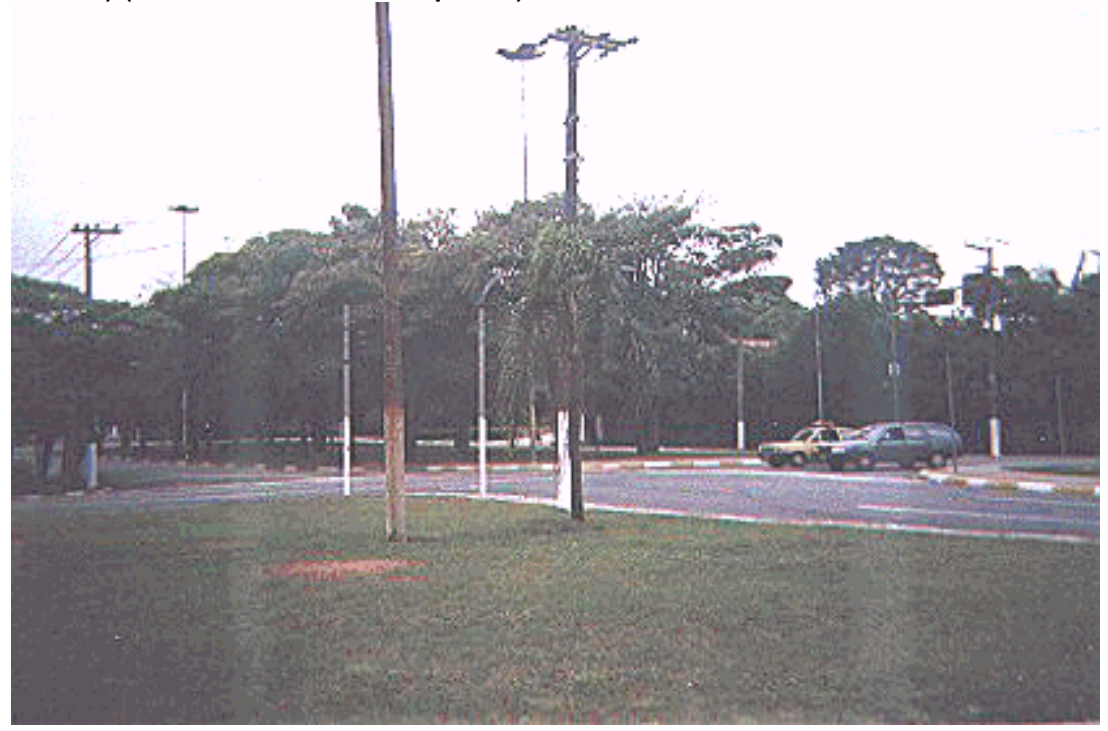

Alto de Pinheiros em 1999 


\section{AVENIDA PAULISTA}

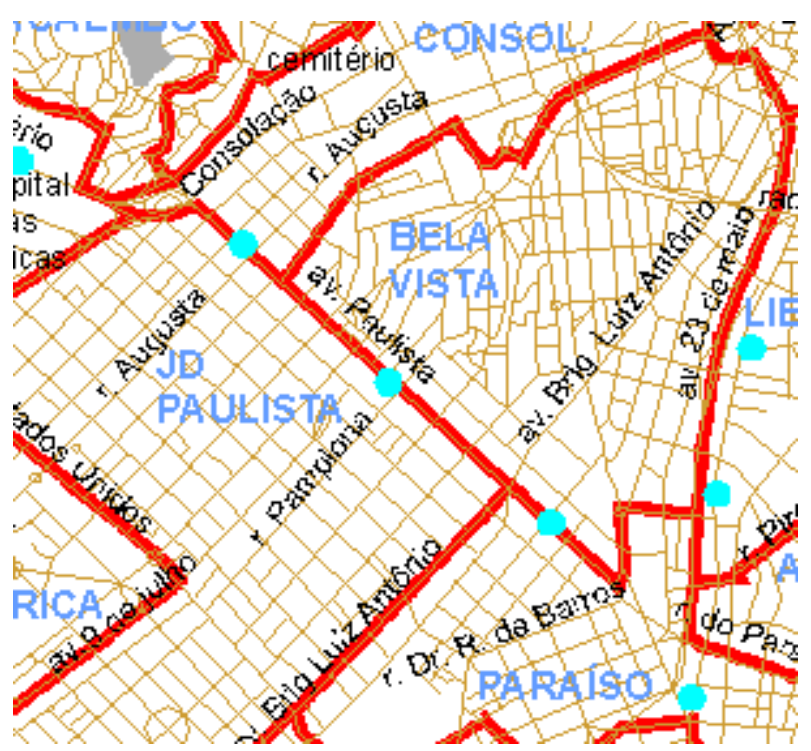

\section{ANTERIOR 1890}

\section{0-1921}

A avenida Paulista foi inaugurada em 1891 como residencial horizontal de elite (REALE, E. 1982 p.110)(ICl 1994 v.8 p.13), sendo ocupada por fazendeiros, comerciantes e industriais (ICl 1994 v.8 p.13)(JORGE, C s/d p.121) e principalmente após o final da primeira guerra por imigrantes enriquecidos (HOMEM, M. 1980 p.42)(REALE, E. 1982 p.120). No início do século iniciou-se a ocupação não residencial, com a instalação em 1903, por exemplo do Instituto Pasteur e de colégios (ICl 1994 v.8 p.30).

\section{2-1951}

Em 1933 iniciou-se a verticalização com a construção do primeiro prédio na avenida (HOMEM, M. 1980 p.154). Essa verticalização intensificou-se nas décadas posteriores (SOMEKH, N. 1989 p.64).

\section{2-1971}

Na década de 50 foi inaugurado o Conjunto Nacional, que segundo Cordeiro iniciou a ocupação terciária da avenida (CORDEIRO, H. 1980 p.66)(ICl 1994 v.8 p.22). Logo, lojas de alto padrão se instalaram na Paulista, que se transformou, como afirma Villaça, no centro da elite (VILLAÇA, F. 1998 p.265)(CORDEIRO, H. 1993 p.11)(ICl 1994 v.8 p.22).

\section{2-1999}

Nos anos 70 intensificou-se a ocupação por edifícios de empresas e bancos, além de órgãos e empresas públicas. Em 1979 foi inaugurado, por exemplo a sede da FIESP (Federação da Indústria do Estado de São Paulo (CORDEIRO, H. 1980 p.26, p.66 e p.88)(ICl 1994 v.8 p.26). Nesse período a avenida se consolidou como centro empresarial e de lazer (CORDEIRO, H. 1980 p.88 e p.147)(REALE, E. 1982 p.120) (PMSP 2000 mapa uso solo 1999). 


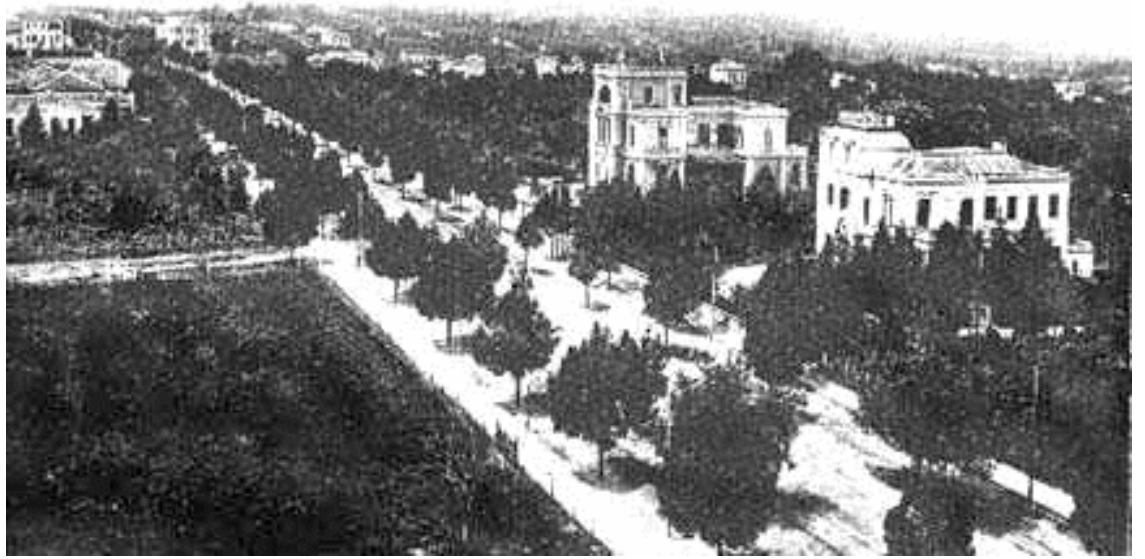

Avenida Paulista em 1906, foto de Guilherme Gaensly (ACERVO DO ARQUIVO DO ESTADO, PROIBIDA REPRODUÇÃO)

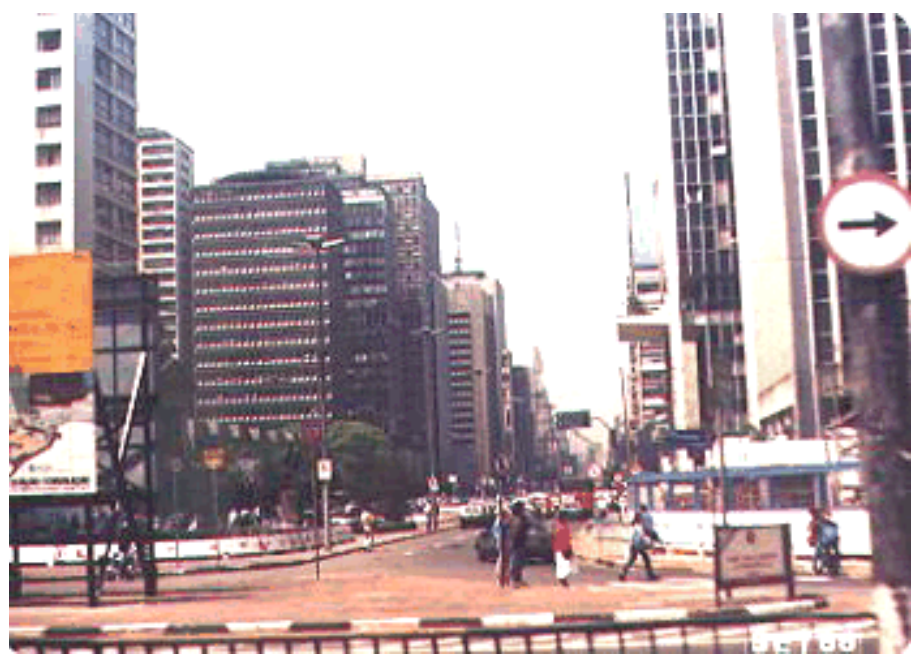

Avenida Paulista em 1988 


\section{BARRA FUNDA}

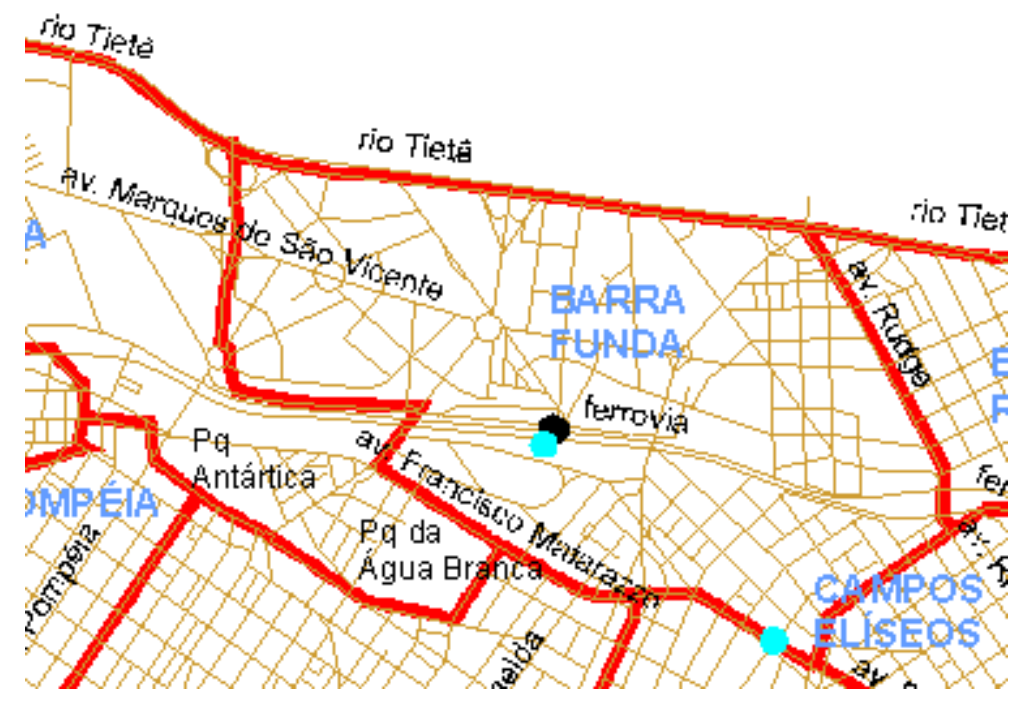

\section{ANTERIOR A 1890 1890-1921}

Nesse período o bairro se consolidou como residencial horizontal operário, com presença de cortiços e como bairro industrial nas proximidades da ferrovia (ROLNIK, R. 1997 p.82)(HOMEM, M. 1980 p.25)(SEGATTO, J. 1988 p.32), com algumas residências de bom padrão próximo ao bairro dos Campos Elíseos (HOMEM, M. 1980 p.24).

\section{2-1951}

Manteve suas características, principalmente de bairro residencial operário e industrial. A partir dos anos 40 apresentou alguma verticalização residencial (SOMEKH, N. 1989 p.124).

\section{2-1971}

Segundo Mendes nos anos 50 o bairro apresentava alguma verticalização (MENDES, R. 1958 p.333) com comércio/serviços e indústria na área próxima à via férrea e diminuição de residências de bom padrão nas proximidades dos Campos Elíseos (MENDES, R. 1958 p.332). Nos anos 60 segundo Feldman ainda havia presença de cortiços (FELDMAN, S. 1989 p.105). 1972-1999

Declínio da função industrial e aumento do comércio/serviços (PMSP 2000 mapa de uso do solo 1999)(ANDRADE, M. 1994 p.97). 

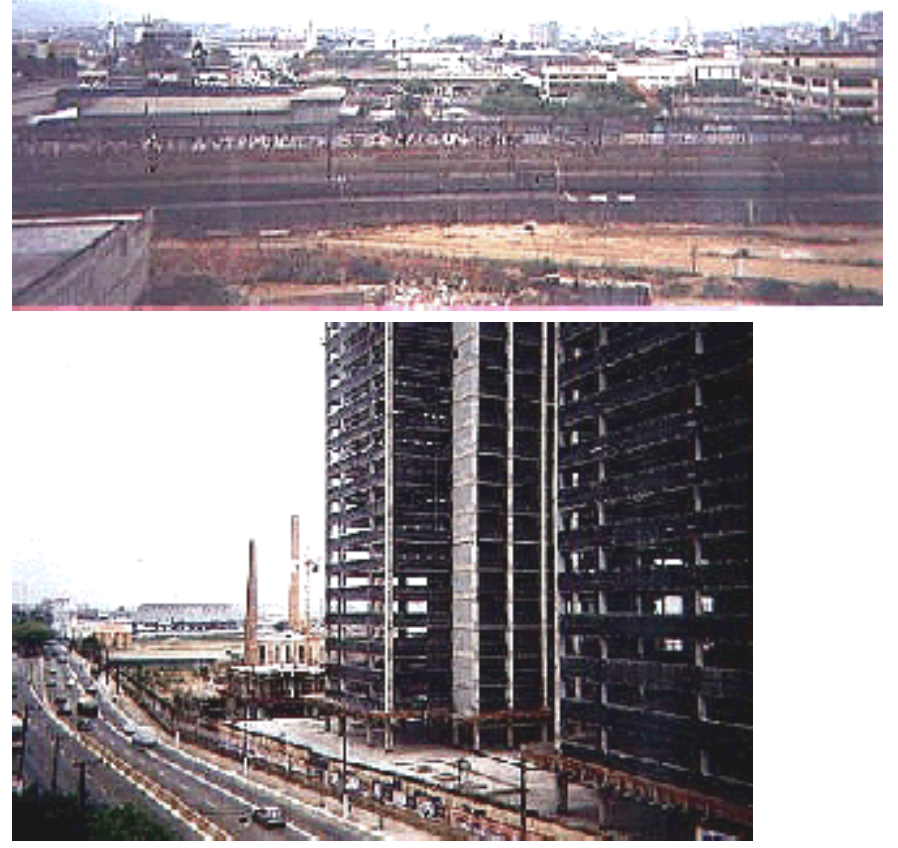

Barra Funda, área da ferrovia, fotos de 1999 


\section{BELA VISTA}

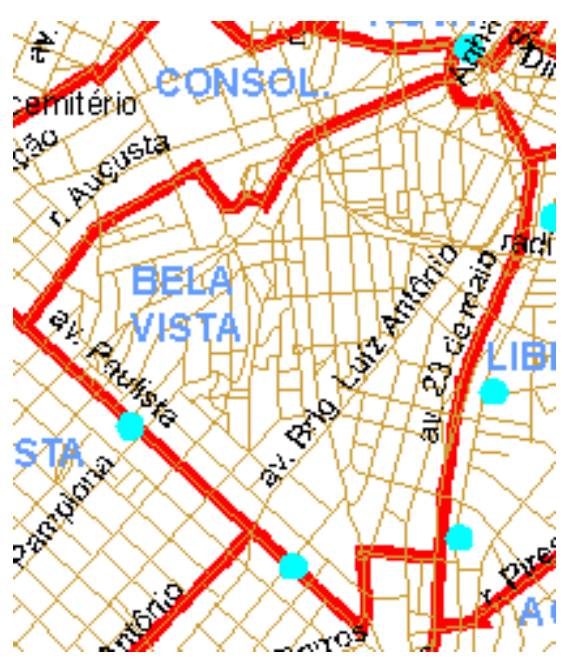

\section{ANTERIOR A 1890}

Próximo ao Piques, na região da atual praça da Bandeira havia um aglomerado de casas e um pouso de tropas, além de um pequeno comércio, entretanto, o bairro iniciou-se em 1878/1879 com o loteamento de antigas chácaras (JORGE, C. s/d p.40 e p.42)(PONCIANO, L. 1999 p.41)(MARZOLA, N. 1979 p.15 e p.63) sendo ocupado por população de poucos recursos, principalmente italianos e negros (MENDES, R. 1958 p.277)(CORDEIRO, H. 1980 p.94).

\section{0-1921}

Durante esse período intensificou-se a ocupação do bairro, com forte presença de imigrantes italianos e cortiços. No início do século XX havia um conjunto de residências de bom padrão na avenida Brigadeiro Luís Antônio (BRUNO, E. 1954 p.947)(PONCIANO, L. 1999 p.41).

\section{2-1951}

A partir dos anos 30 surgiram as primeiras cantinas italianas (MARZOLA, N. 1979 p.68). Após os anos 40 também ocorreu algum crescimento vertical (SOMEKH, N. 1989 p.77). Em 1948 surgiu o primeiro teatro (MARZOLA, N. 1979 p.116)(PONCIANO, L. 1999 p.43).

\section{2-1971}

Segundo Taralli e Mendes, nos anos 50 havia alguma verticalização (TARALLI, C. 1993 p.168)(MENDES, R. 1958 p.280), havia também residências de bom padrão no Morro dos Ingleses, próximo à avenida Paulista (MENDES, R. 1958 p.279). No final dos anos 50 e anos 60 algumas obras alteraram a estrutura viária da região, como a avenida Leste/Oeste, que seccionou o bairro (MARZOLA, N. 1979 p.110) e a avenida Vinte e Três de Maio (PORTO, A. 1992 p.172).

\section{2-1999}

Nesse período ocorreu aumento da verticalização, principalmente no Morro dos Ingleses (CORDEIRO, H. 1980 p.76) e o bairro se consolidou como centro de diversões, a Broadway Paulista, segundo Marzola (MARZOLA, N. 1979 p.16) com grande desenvolvimento de cantinas italianas após os anos 70 (VILLAÇA, F. 1998 p.254), entretanto, com presença de cortiços (OSELLO, M. 1983 p.41)(JORGE, C. s/d p.122). Há também presença de comércio/serviços 
(PMSP 2000 mapa uso solo 1999).

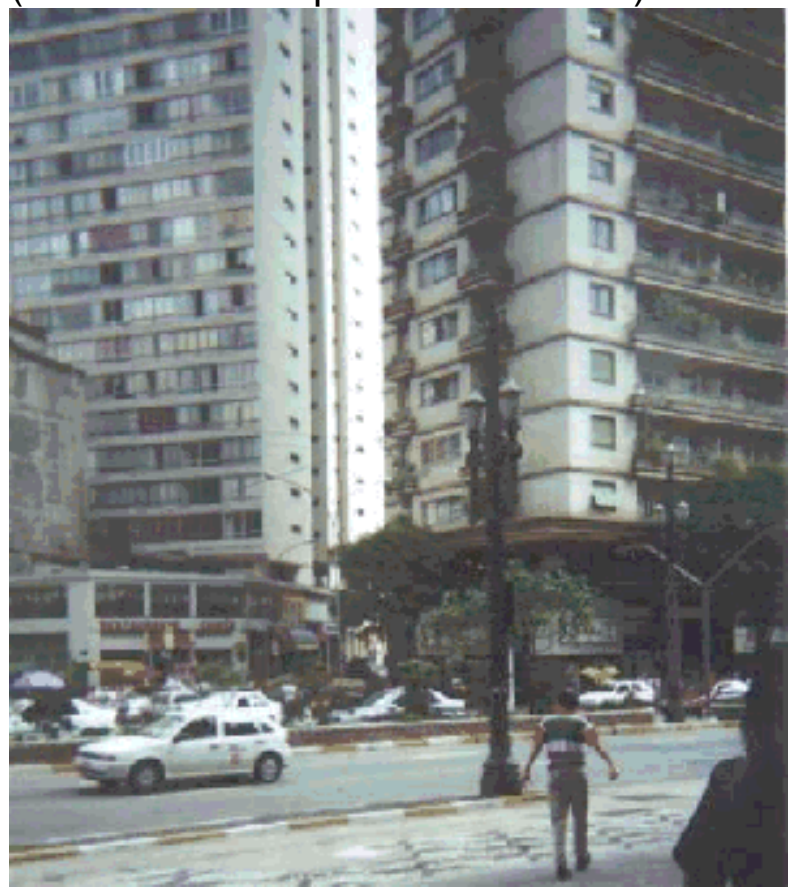

Bela Vista, próximo ao Triângulo. Foto de 2001 


\section{BELÉM}

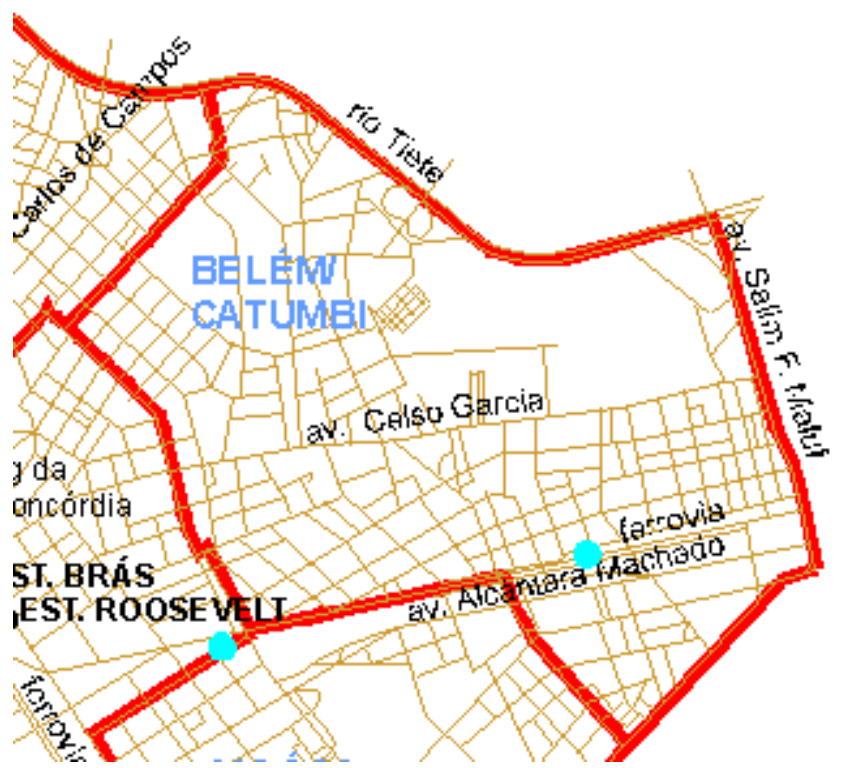

\section{ANTERIOR A 1890}

Além das chácaras, havia em 1880 no local uma estância climática (PONCIANO, L. 1999 p.44). Havia também uma capela, próxima ao marco da meia légua (atualmente rua Catumbi com avenida Celso Garcia) (ANDRADE, M. 1991 p.228).

\section{0-1921}

A partir de 1890 o bairro começou a ser ocupado por indústrias e residências horizontais operárias, (HOMEM, M. 1980 p.25), No início do século XX a ocupação industrial se intensificou, com indústrias de bens de consumo, como alimentos e tecelagens na área próxima à ferrovia (ANDRADE, M. 1994 p.101)(PONCIANO, L. 1999 p.44). O bairro era ocupado principalmente por italianos (ANDRADE, M. 1991 p.228).

\section{2-1951}

Nesse período o bairro manteve suas características de bairro residencial horizontal operário e industrial (MENDES, R. 1958 p.236), com grande crescimento industrial até a década de 50 (ANDRADE, M. 1991 p.175). 1952-1971

Bairro residencial e industrial. Após 1957 a Radial Leste dividiu o bairro do Belém alterando sua estrutura viária (ANDRADE, M. 1991 p.232). Nos anos 60, segundo Feldman ainda existiam cortiços no bairro (FELDMAN, S. 1989 p.105).

\section{2-1999}

Declínio do uso industrial (ANDRADE, M. 1994 p.97) com aumento do comércio/serviços e apartamentos (PMSP 2000, mapa uso do solo 1999). O metrô melhorou a acessibilidade do bairro, mas também deixou algumas áreas desapropriadas sem utilização que só tiveram alguma ocupação em 1986/1987 com a construção de apartamentos (ANDRADE M. 1991 p.232). 


\section{BOAÇAVA}

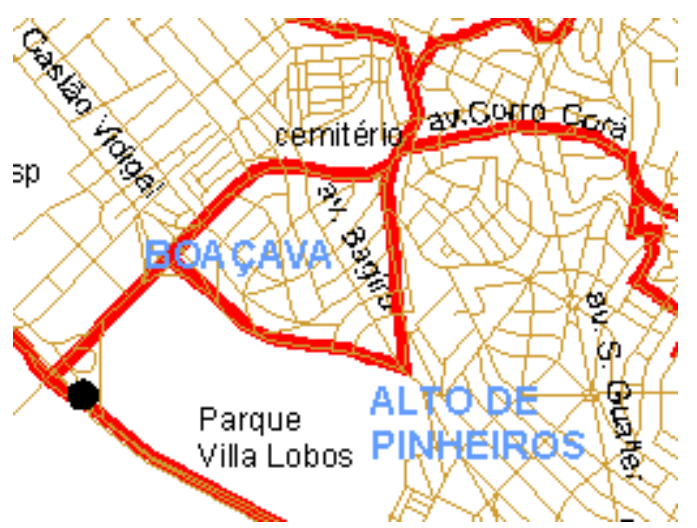

\section{ANTERIOR A 1890}

\section{0-1921}

\section{2-1951}

O bairro foi loteado em 1949 como residencial horizontal de elite (BACELLI, R. 1982 p.62)(LOBO JR, m. 1986 p.11). Em 1952 ainda não estava ocupado (VASP/CRUZEIRO levantamento aéreo 1952/1959).

\section{2-1971}

Manteve suas características de bairro residencial de elite, tendo aumento em sua ocupação pois mapa do Gegran na escala 1:2000 de 1972 já indicava um número maior de residências.

1972-1999

Manteve suas características de bairro residencial de elite (PMSP 2000 v.1 p.44). 


\section{BOM RETIRO}

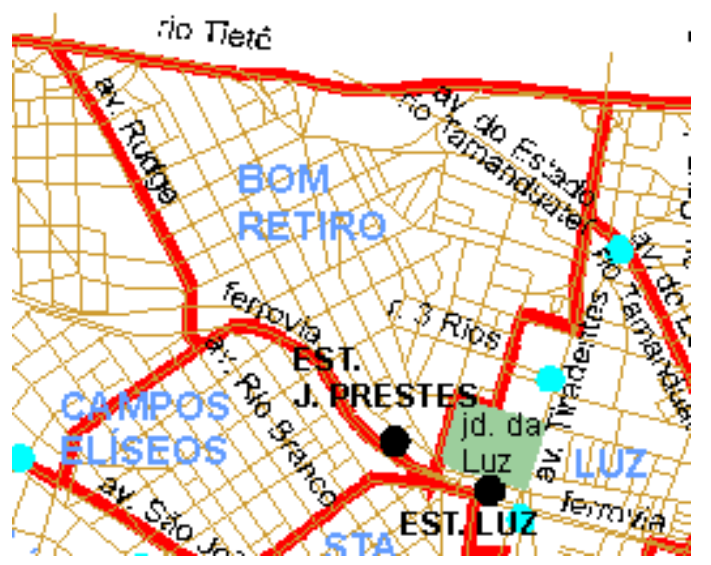

\section{ANTERIOR A 1890}

Ocupação dispersa, que se intensificou após 1867 com a inauguração da ferrovia (DERTÔNIO, H. 1971 p.13 e p.58). Após 1880 a ocupação se intensificou, como residencial horizontal operário, cortiços e industrial (PONCIANO, L. 1999 p.38). Em 1881 chegou a haver no local uma hospedaria de imigrantes (ANDRADE, M. 1994 p.98)(TORRES, M. 1969 p.167).

\section{0-1921}

Nesse período permaneceu residencial operário e industrial. A partir do início do século recebeu imigração de israelitas que construíram sinagoga no bairro. Houve também alguma expansão comercial (DERTÔNIO, H. 1971

p.13)(SANTOS, M. 2000 p.95). As áreas de várzeas ainda permaneciam com pouca ocupação (SANTOS, M. 2000 p.87).

\section{2-1951}

A partir da década de 30 intensificou-se o fluxo migratório israelita devido principalmente ao crescimento do nazismo na Europa. Essa população colaborou com o desenvolvimento do comércio/serviços no bairro, sendo pioneira na venda a crédito (PONCIANO, L. 1999 p.38). Nos anos 40 houve melhora no acesso ao bairro com a avenida Tiradentes (SANTOS, M. 2000 p.105) e alguma verticalização (SANTOS, M. 2000 p.110)(SOMEKH, N. 1989 p.77). Nesse período continuou a presença de cortiços. Antes dos anos 40 já havia prostituição no bairro. Essa prostituição aumentou, ainda nos anos 40 , com o confinamento da prostituição da cidade na área, provocando, segundo Dertônio, o afastamento das residências e sua ocupação, devido a queda dos preços, por pequenas indústrias (ROLNIK, R. 1997 p.86)(DERTÔNIO, H. 1971 p.69)(FELDMAN, S. 1989 mapa 1).

\section{2-1971}

Na década de 50 o bairro ainda mantinha usos do período anterior, inclusive cortiços (MENDES, R. 1958 p.204). Em 1953 foi decretado o fim do confinamento da prostituição no bairro (FELDMAN, S. 1989 p.105). A partir dos anos 60 houve uma diminuição da população israelita (SANTOS, M. 2000 p.97), que enriquecida mudou-se para outros bairros. Em $1962 \mathrm{com}$ a inauguração da rodoviária nas proximidades do bairro ocorreu um aumento do fluxo de pessoas (SANTOS, M. 2000 p.106). Houve também alguma verticalização (DERTÔNIO, H 1971 p.59). 
No final dos anos 70 houve um aumento na população de origem coreana, o que reforçou o comércio e indústria de confecções (PONCIANO, L. 1999 p.38). O metrô melhorou o acesso ao bairro (SANTOS, M. 2000 p.107) e o comércio continuou seu crescimento, com grande rotatividade de lojas (SANTOS, M.

p.107 e p. 112). Houve também aumento da verticalização (SOMEKH, N. 1989 p.103).

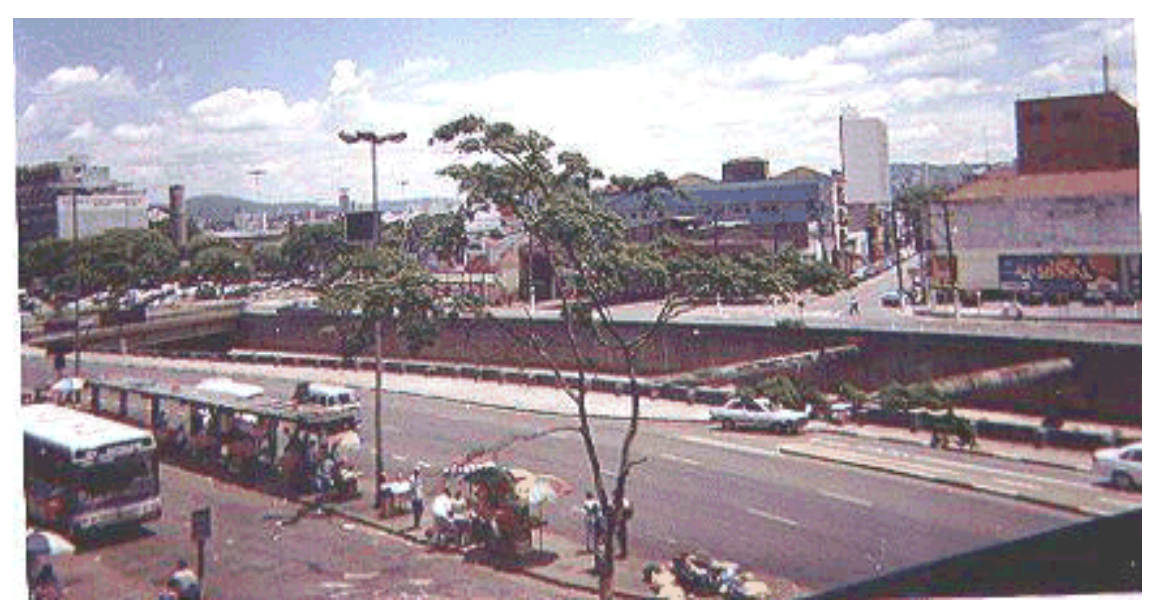

Bom Retiro, próximo à Avenida do Estado. Foto de 2001 


\section{BRÁS, GLICÉRIO, MERCADO E CARMO}

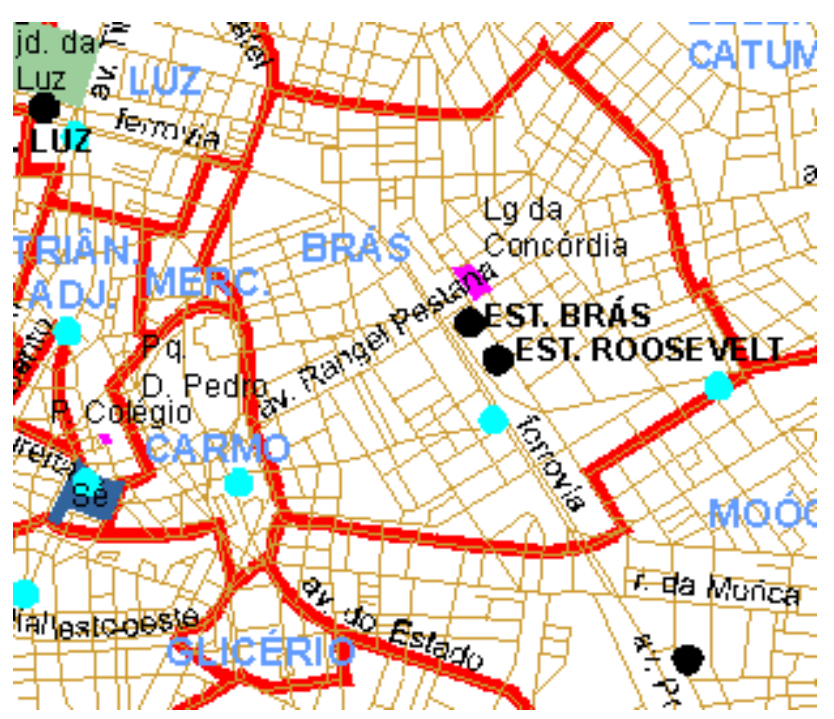

\section{ANTERIOR A 1890}

Desde o século XVIII a igreja de Bom Jesus Matosinhos atraiu população para o bairro do Brás, onde havia também um pouso destinado aos romeiros que se dirigiam à Penha (REALE, E. 1982 p.4)(PONCIANO, L. 1999 p.45). Em 1800 já havia construções no local, entremeados de chácaras e oficinas artesanais (GUIMARÃES, L. 1979 p.38)(REALE, E. 1982 p.7). Em 1867 com a inauguração da primeira estação ferroviária no Brás pela SP Railway e em 1877 com a estação ferroviária do Norte intensificou-se a ocupação para uso industrial e residencial operário, principalmente italianos. (ANDRADE M. 1994 p.98). Após 1887 aumentou o fluxo de pessoas para o bairro com a inauguração da nova hospedaria dos imigrantes (ANDRADE, M. 1994 p.98). Desde esse período já existia algum comércio próximo às estações, já servidas por linhas de bondes (REALE, E. 1982 p.17 e p.24).

Desde meados do século XIX o Carmo apresentava um padrão de ocupação diferente, com residências de bom padrão, permanecendo assim até mais ou menos 1875 (TARALLI, C. 1993 p.192)(VILLAÇA, F. 1998 p.268).

1890-1921

Em 1890 a região do Carmo já se encontrava ocupada por população de baixa renda, inclusive com a presença de cortiços (REALE, e. 1982 p.26) (VILLAÇA, F. 1998 p.263). O Brás se consolidou nesse período como bairro industrial e residencial operário, com cortiços (TORRES, M. 1969 p.123)(REALE, E. 1982 p.50). Em 1910 o Brás já começava a se destacar pela presença de uso comercial, se consolidando nos anos 20 como subcentro comercial popular (VILLAÇA, F. 1998 p.294).

\section{2-1951}

Segundo Andrade, o crescimento industrial no Brás se prolongou até os anos 30 (ANDRADE, M. 1991 p. 175). Nessa década, o Brás e região já eram densamente ocupados, havendo no Brás muitas cantinas e teatros (MARTIN, A. 1984 p.166). Ocorreu também um afastamento da população de origem italiana, que se mudou para outros bairros e a partir dos anos 40 houve um aumento do número de migrantes nordestinos (PONCIANO, L. 1999 p.47). A partir dos anos 40 também se intensificou o uso comercial/serviços (TORRES, M. 1969 p.217)(MARTIN, A. 1984 p.170). Nesse período, segundo Feldman 
havia ainda na região muitos cortiços e também locais de prostituição (FELDMAN, S. 1989 mapas 1, 2 e 3). Nos anos 40 a construção do viaduto do Gasômetro melhorou a acessibilidade do bairro (MARTIN, A. 1984 p.171). 1952-1971

Nos anos 50 havia pequeno crescimento vertical (MENDES, R. 1958 p.241)(SOMEKH, N. 1989 p.84). O comércio continuou se desenvolvendo, nesse período havia também muitas cantinas no Brás (VILLAÇA, F. 1998 p.312). Nos anos 50 também havia forte comércio atacadista na região do Mercado (MENDES, R. 1958 p.259) e alguma verticalização no Glicério (MENDES, R. 1958 p.259). Em 1957 a avenida Radial Leste alterou a estrutura viária da região, com mudança de uso, pois o comércio dessa avenida deixou de servir à população local (MARTIN, A. 1984 p.172). Ocorreu nesse período, principalmente no Brás, a saída de moradores para outros bairros, os mais abastados para bairros considerados melhores e aqueles de menor renda, devido a elevação do preço dos aluguéis para a periferia da zona leste. (ANDRADE, M. 1991 p.224 e p.230). Nos anos 60 uma colônia coreana se instalou no Glicério (GUIMARÃES, L. 1979 p.108). A construção de obras viárias, principalmente viadutos nos anos 60 no Brás contribuíram para melhoria da acessibilidade (MARTIN, A. 1984 p.172).

\section{2-1999}

Nesse período ocorreu a diminuição das cantinas (ver Bela Vista)(VILLAÇA, F. 1998 p.312). Houve também a diminuição da população de origem italiana e o aumento da população de origem nordestina (TORRES, M. 1969

p.225)(MARTIN, A. 1984 p.170). A construção do metrô nos anos 80 contribuiu para melhoria na acessibilidade do bairro, deixando, entretanto, algumas áreas desapropriadas vazias, ocupadas apenas no final da década com apartamentos (ANDRADE, M. 1991 p.232). Houve o declínio das atividades industriais e o aumento do comércio e serviços (ANDRADE, M. 1994 p.97)(PMSP 2000, mapa uso do solo). 


\section{CAMBUCI}

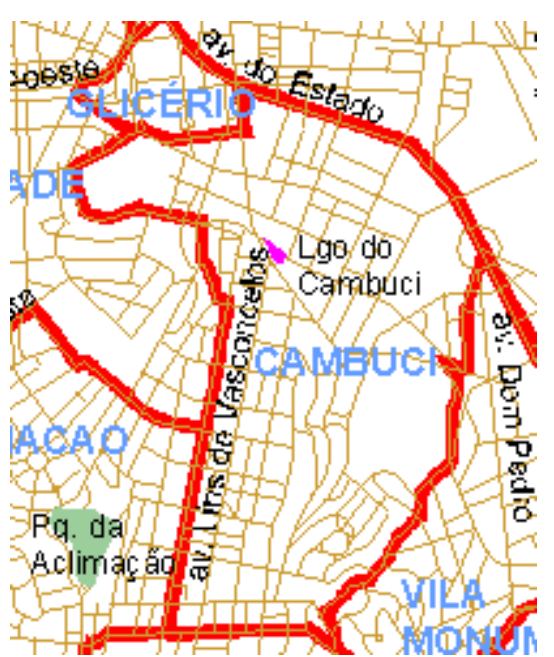

\section{ANTERIOR A 1890}

Era uma região de chácaras, em 1877 existiu na região um núcleo colonial, que fracassou (MENDES, R. 1958 p.262).

\section{0-1921}

No final do século XIX a região foi loteada e ocupada por uso residencial horizontal operário (com forte presença de imigrantes italianos), inclusive com cortiços e algumas indústrias próximas à ferrovia principalmente (PONCIANO, L. 1999 p.50)(MENDES, R. 1958 p.263)(BRUNO, E. 1954 p.955)(ROLNIK, R. 1997 p.82).

\section{2-1951}

Manteve seu uso residencial horizontal operário e industrial, porém, a partir dos anos 30 surgiram alguns loteamentos de classe média nas proximidades de Vila Mariana (MÜLLER, N. 1958 p.167).

\section{2-1971}

Segundo Müller nos anos 50 já havia algum comércio/serviços próximo ao largo do Cambuci (MÜLLER, N. 1958 p.167).

\section{2-1999}

Ocorre um declínio no uso industrial e um aumento no uso comercial/serviços e apartamentos (PMSP 2000, mapa uso do solo 1999)(ANDRADE, M. 1994 p.97). 


\section{CAMPOS ELÍSEOS}

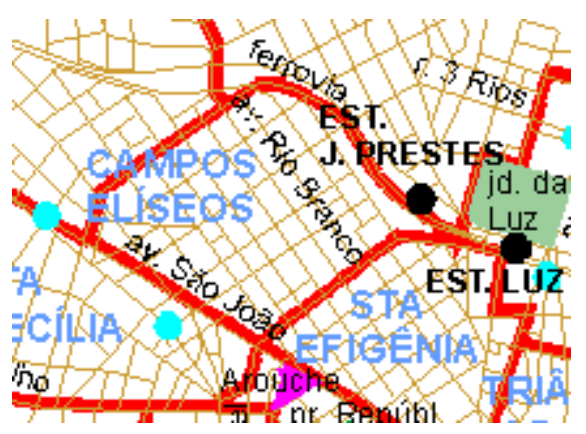

\section{ANTERIOR A 1890}

Nasceu como bairro residencial de elite em 1879 (PONCIANO, L. 1999 p.51)(VILLAÇA, F. 1998 p.194)(HOMEM, M. 1980 p.24).

\section{0-1921}

Continuou como bairro residencial de elite, já sofrendo, no entanto, com a concorrência de outros bairros residenciais de alto padrão, como a região de Higienópolis e av. Paulista, distantes dos usos inconvenientes gerados pela ferrovia (MENDES, R. 1958 p.202).

\section{2-1951}

No final da década de 20 iniciou-se a saída da elite do bairro (ICl 1995 v12 p.13) e sua ocupação por novos usos. Em 1932 se instalou no bairro a sede do governo estadual (ICl 1994 v2 p.15). Nos anos 40 iniciou-se a verticalização (SOMEKH, N. 1989 p.77).

\section{2-1971}

Nos anos 50 já não era ocupado pelo uso residencial horizontal de elite, mas sim por moradores de menor poder aquisitivo, inclusive com a presença de cortiços e prostituição (MENDES, R. 1958 p.201 e p.204). Em 1962, com a inauguração da Rodoviária novos usos são atraídos para o bairro, principalmente hotéis e comércio (FELDMAN, S. 1989 p.122). Nesse período também aumentou a verticalização (ICl 1995 v12 p.9)(SANTOS, M. 2000 p.106).

\section{2-1999}

Bairro comercial/serviços com uso residencial vertical (CESAD/FAUUSP/PMSP TPCL 1971), com presença de cortiços (MARZOLA, N. 1979 p.81). Em 1988 a Rodoviária se transformou em Shopping de caráter popular (ICl 1995 v.12 p.21). 


\section{CERQUEIRA CÉSAR}

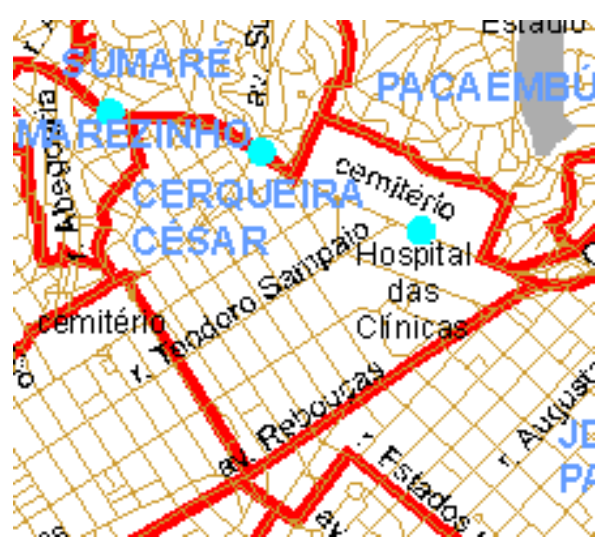

\section{ANTERIOR A 1890}

\section{0-1921}

Cerqueira César nasceu como bairro residencial horizontal de classe média nas proximidades do Hospital de Isolamento (REALE, E. 1982 p.70)(VILLAÇA, F. 1998 p.112). Com a extensão das linhas de bonde para a área foi ocupado rapidamente (MENDES, R. 1958 p.307).

\section{2-1951}

A partir dos anos 40 iniciou-se algum crescimento vertical (SOMEKH, N. 1989 p.79).

\section{2-1971}

Nos anos 50 além da ocupação residencial horizontal de classe média com desenvolvimento de uso residencial vertical (TARALLI, C. 1993 p.168), segundo Mendes, havia uma área de residências de bom padrão na avenida Rebouças (MENDES, R. 1958 p.307) e já havia algum desenvolvimento comercial/serviços na rua Teodoro Sampaio (MENDES, R. 1958 p.307). 1972-1999

A partir dos anos 70 ocorreu grande processo de verticalização, com aumento também no uso comercial/serviços (SOMEKH, N. 1989 p.140)(CORDEIRO, H. 1980 p.74). Os anos 80 marcaram o inicio do desenvolvimento do lazer noturno na avenida Henrique Schaumann (REALE, E. 1982 p.102). Em 1999 é uma área constituída por comércio/serviços e apartamentos de classe média (PMSP 2000 mapa uso do solo 1999). 


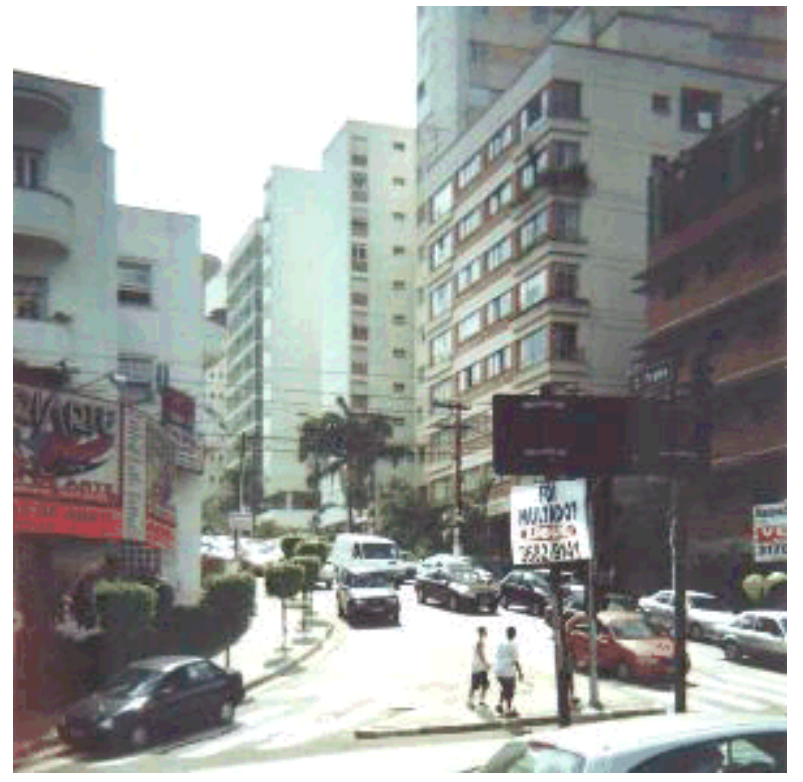

Cerqueira César, r. Oscar Freire. Foto de 2001 


\section{CANINDÉ / PARI}

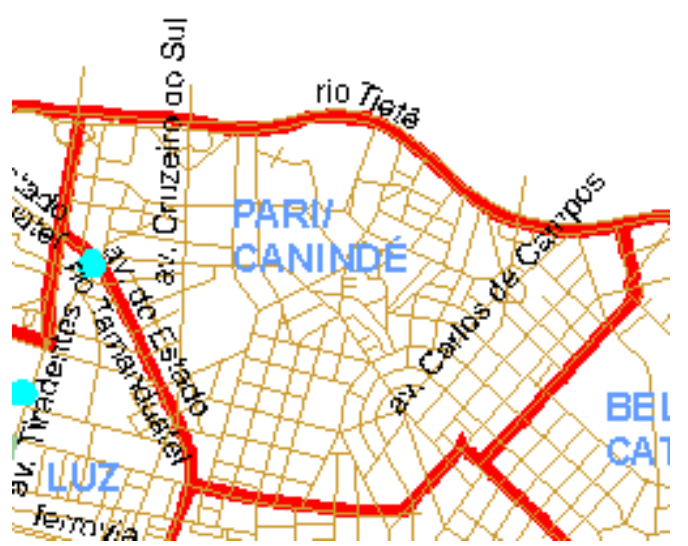

\section{ANTERIOR A 1890}

\section{0-1921}

Desde o final do século XIX a região se formou como bairro industrial e residencial operário, principalmente nas proximidades da ferrovia (HOMEM, M. 1980 p.25).

\section{2-1951}

Manteve seu caráter residencial operário e industrial (MENDES, R. 1958 p.299).

\section{2-1971}

Segundo Mendes, nos anos 50 o bairro continuou residencial operário com presença de indústrias e armazéns atacadistas (MENDES, R. 1958 p.198 e p.236). No final dos anos 60 o mapa do uso do solo do PUB (Plano Urbanístico Básico) apontava forte influência comercial (SÃO PAULO (PMSP) 1969 - mapa uso do solo 1968). Dados do TPCL 1971 também apontavam a existência de uso comercial (CESAD/FAUUSP/PMSP TPCL 1971).

\section{2-1999}

Nesse período houve aumento do comércio/serviços e a diminuição do uso industrial, embora ainda exista um certo número de fábricas, principalmente de doces (PMSP 2000 mapa uso do solo)(PONCIANO, L. 1999 p.99).

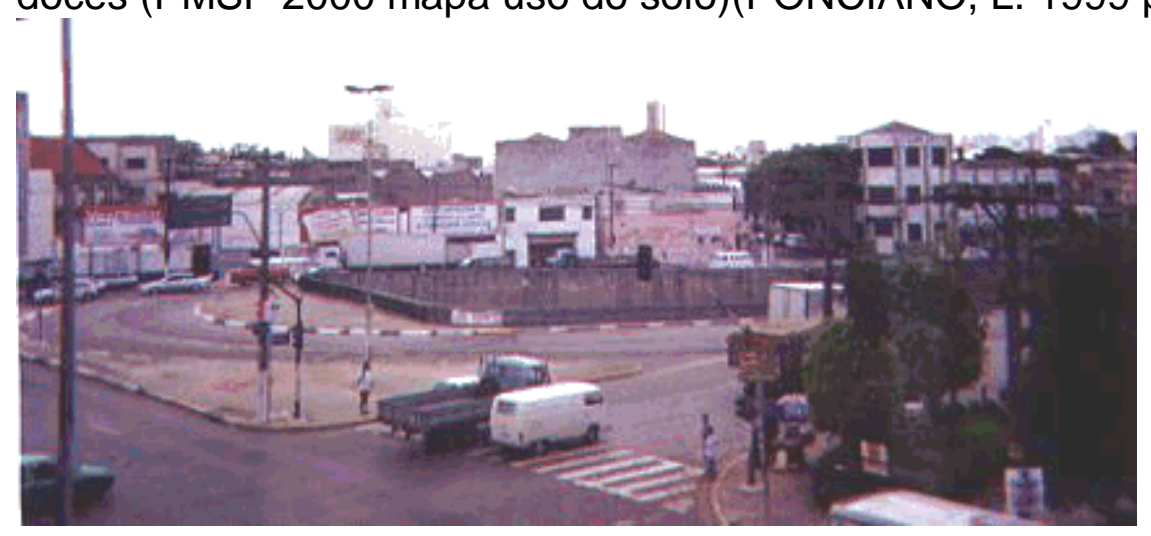

Pari, proximo à Avenida do Estado. Foto de 2001 


\section{CIDADE NOVA}

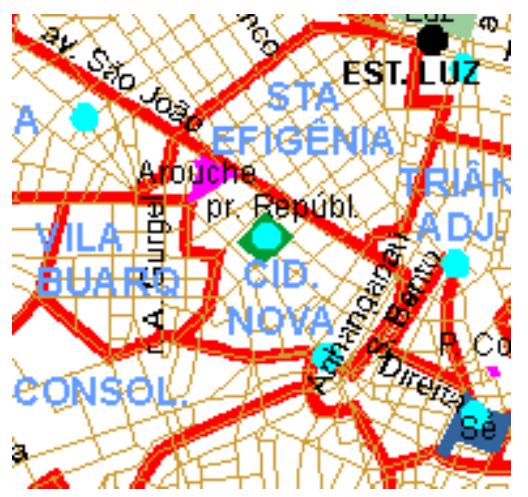

\section{ANTERIOR A 1890}

A região para além do vale do Anhangabaú já possuía uma ocupação esparsa desde 1750 (JORGE, C. S/D p.81). Após 1810 essa ocupação intensificou-se um pouco com o loteamento de chácaras da região (MENDES, R. 1958 p.193)(GUIMARÃES, L. 1979 p.381)(TOLEDO, B.1981 p.88). Nesse período a praça da República foi usada para exercícios militares, sendo conhecida como praça da Legião e logo depois praça dos Milicianos. Após 1817 passou a ser conhecida como praça dos Curros, um local de touradas, cavalhadas e circo (PONCIANO, L. 1999 p.106)(ICl 1995 v.13 p.11).

\section{0-1921}

Em 1892 foi inaugurado o novo viaduto Chá que melhorou o acesso ao bairro (PORTO, A. 1992 p.73). No final do século XIX uma série de novos edifícios foi construída no bairro e proximidades, como o Teatro Politeama na avenida São João (PORTO, A. 1992 p.75), a Escola Normal na praça da República (PORTO, A. 1992 p.78). Nesse período havia uma área residencial de bom padrão nas proximidades da atual avenida São Luís (VILLAÇA, F. 1998 p.264). Em 1903 foi inaugurado o Teatro São José (ICl 1992 v.1 p.9). Em 1911 foi inaugurado o Teatro Municipal na praça Ramos de Azevedo (PORTO, A. 1992 p.78). Já nesse período, segundo Villaça, a região começou a receber as primeiras influências do uso comercial do centro histórico (VILLAÇA, F. 1998 p.264)(BRUNO, E. 1954 p.1168).

\section{2-1951}

Em 1922 foi inaugurado na avenida São João na divisa da Cidade Nova com a Santa Efigênia o prédio dos Correios (PORTO, A. 1992 p.79). Na década de 20 iniciou-se a incorporação do bairro ao Triângulo e Adjacências (SOMEKH, N. 1989 p.62)(MÜLLER, N. 1958 p.142). Nas décadas de 30 e 40 intensificouse a instalação de comércio/serviços e de repartições públicas na área, com início da verticalização no bairro. Em 1930, por exemplo o Mappin mudou-se para o bairro e foi instalada a Biblioteca Municipal (MÜLLER, N. 1958

p.142)(SOMEKH, N. 1989 p.63 E p.65)(VILLAÇA, F. 1998 p.264)(JORGE, C. S/D p.177)(TARALLI, C. 1993 p.124).

\section{2-1971}

A partir dos anos 50 o bairro já se encontrava bem verticalizado e consolidado como comercial/serviços de elite (SOMEKH, N. 1989 p.63)(VILLAÇA, F. 1998 p.264). A partir dos anos 60 a Cidade Nova começou a deixar de ser o centro comercial/serviços de elite (VILLAÇA, F. 1998 p.265), mas até os anos 70 ainda eram implantados grandes edifícios de escritórios (ICl 1992 v.1 p.106). 


\section{2-1999}

Com forte predominância do uso comercial e de serviços a região possui uso comercial principalmente popular, além de vida noturna. Alguns apartamentos de bom padrão estão localizados na região da avenida São Luís (VILLAÇA, F. 1998 p.254)(CORDEIRO, H. 1980 p.104)(PMSP 2000, mapa uso do solo 1999). Há muitos edifícios vagos na região (IBGE 2001).

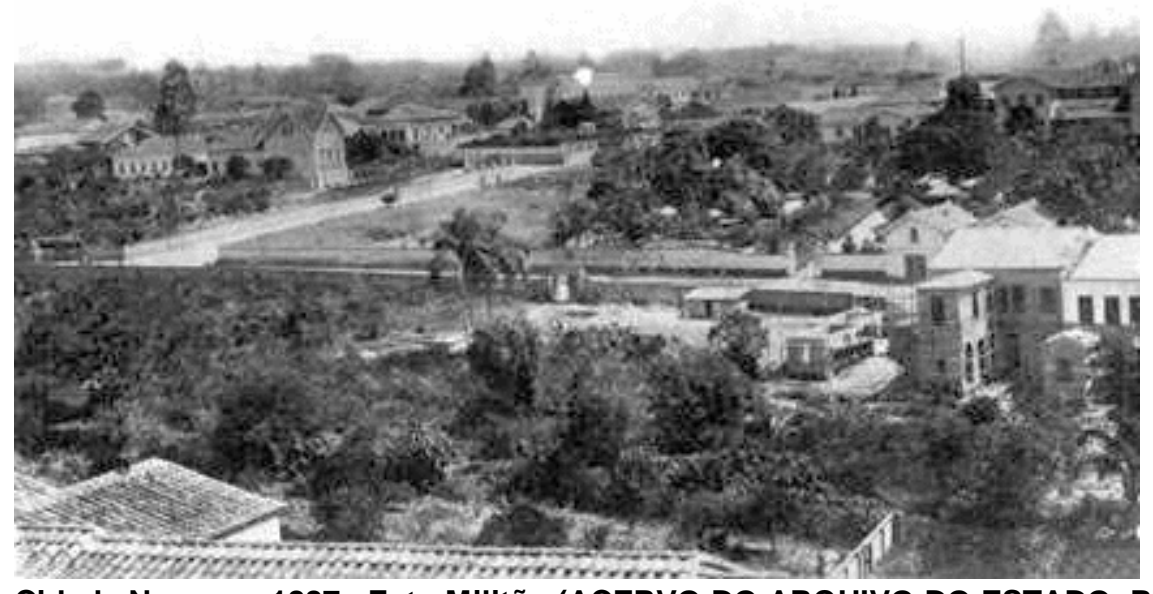

Cidade Nova em 1887. Foto Militão (ACERVO DO ARQUIVO DO ESTADO, PROIBIDA REPRODUÇÃO)
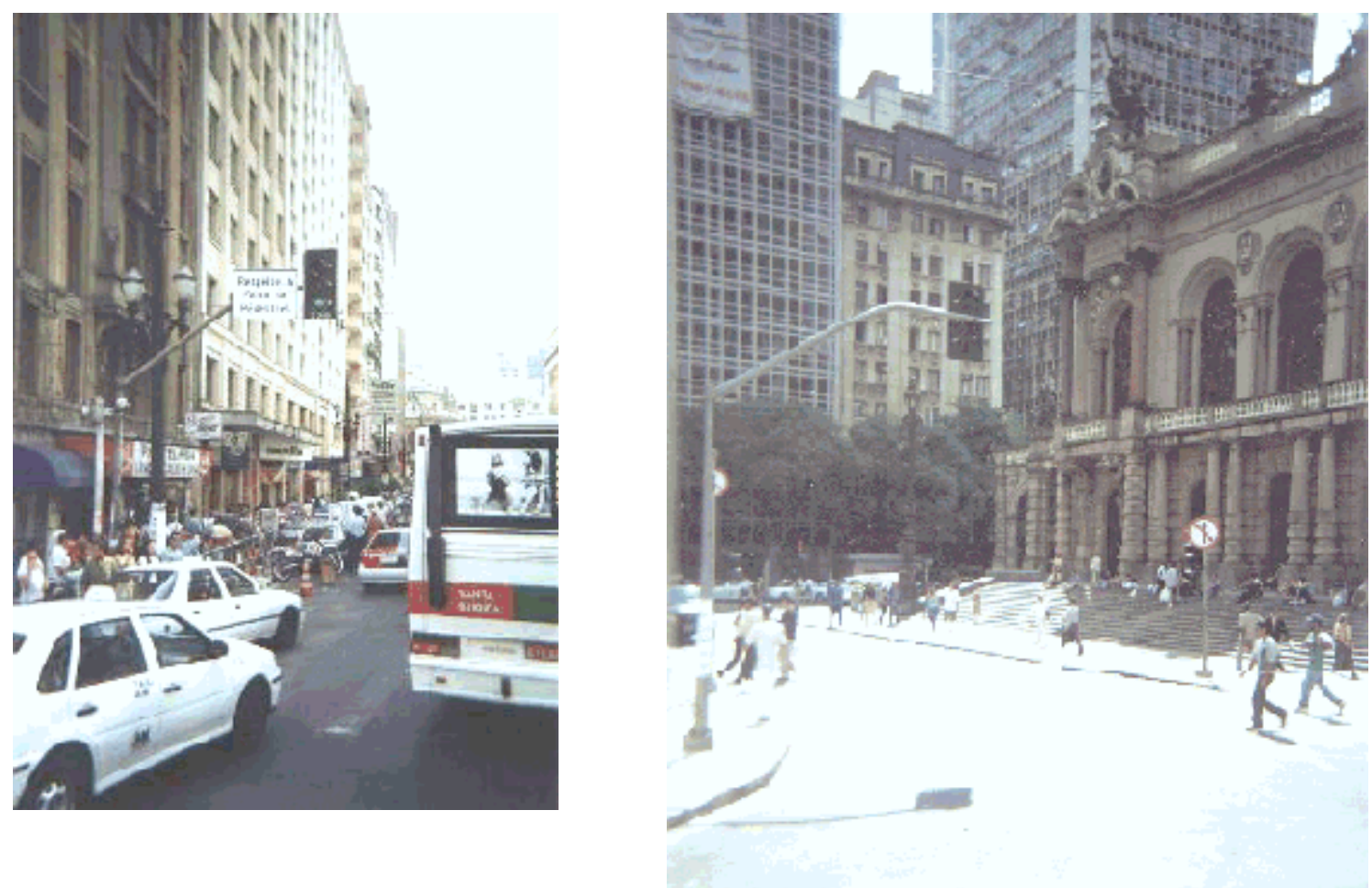

Cidade Nova em 2001. R. Xavier de Toledo (esquerda) e Teatro Municipal (direita) 


\section{CONSOLAÇÃO}

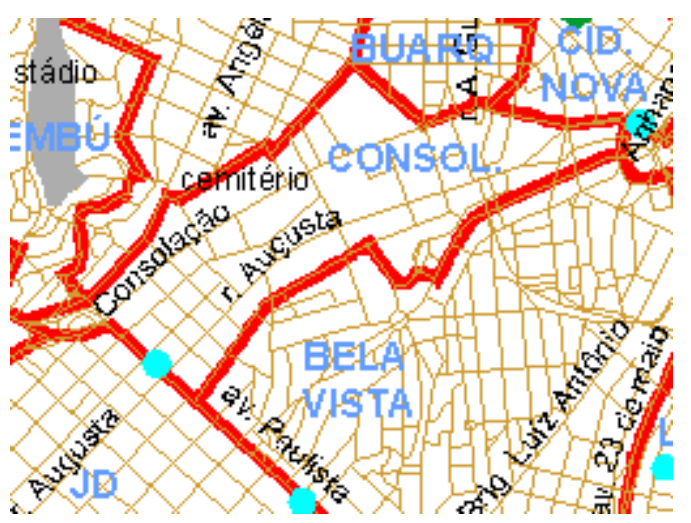

\section{ANTERIOR A 1890}

No último quartel do século XIX a região era ocupada por algumas residências de classe média, algumas delas até de bom padrão (BRUNO, E. 1954 p.1042)(PONCIANO, L. 1999 p.60)(GUIMARÃES, L. 1979 p.48).

\section{0-1921}

Manteve suas características de residencial horizontal de classe média (HOMEM, M. 1980 p.24)(CORDEIRO, H. 1980 p.71).

\section{2-1951}

A partir de 1945 iniciou-se a verticalização residencial (SOMEKH, N. 1989 p.79).

\section{2-1971}

Nesse período o bairro sofreu intensa verticalização com aumento de comércio e serviços (HOMEM, M. 1980 p.162)(MÜLLER, N. 1958 p.167). A partir dos anos 60 se instalaram no bairro muitos hotéis (JORGE, C. s/d. p.194).

\section{2-1999}

Nesse período caracterizou-se por ser um bairro verticalizado, com grande concentração de comércio e serviços, além de vida noturna. Há também comércio especializado de lustres e luminárias na avenida Consolação (CORDEIRO, H. 1980 p.144)(VILLAÇA, F. 1998 p.254)(PONCIANO, L. 1999 p.60). 


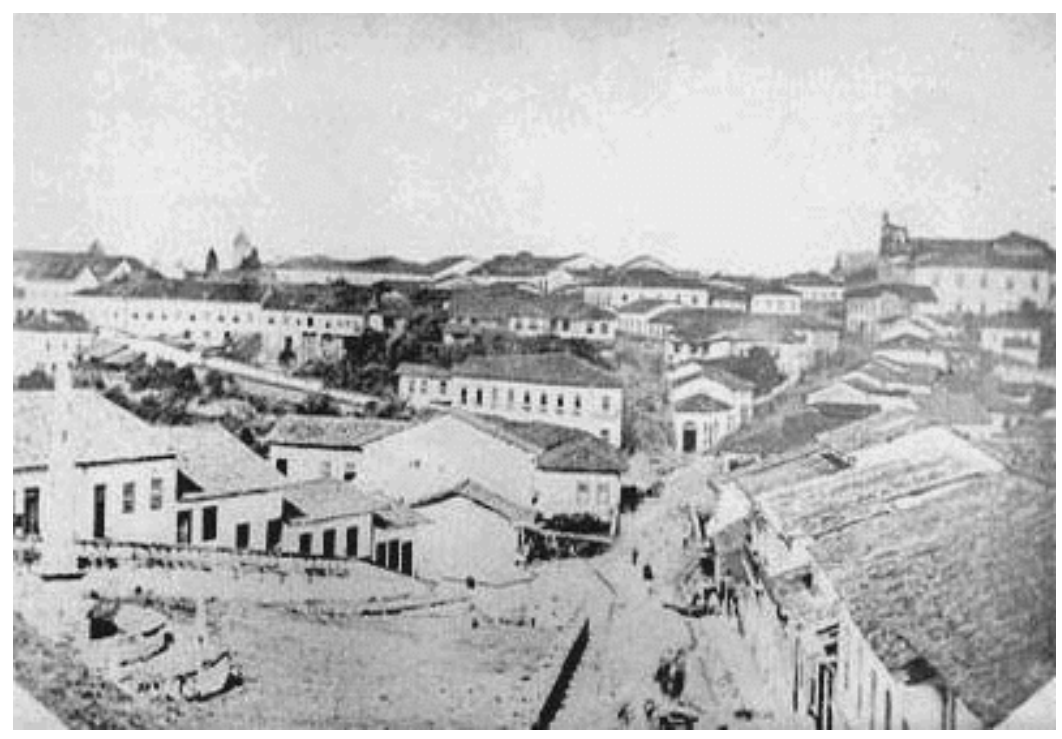

Rua Quirino de Andrade em 1860 na divisa entre a Consolação e a Cidade Nova. Foto Militão (ACERVO DO ARQUIVO DO ESTADO, PROIBIDA REPRODUÇÃO)

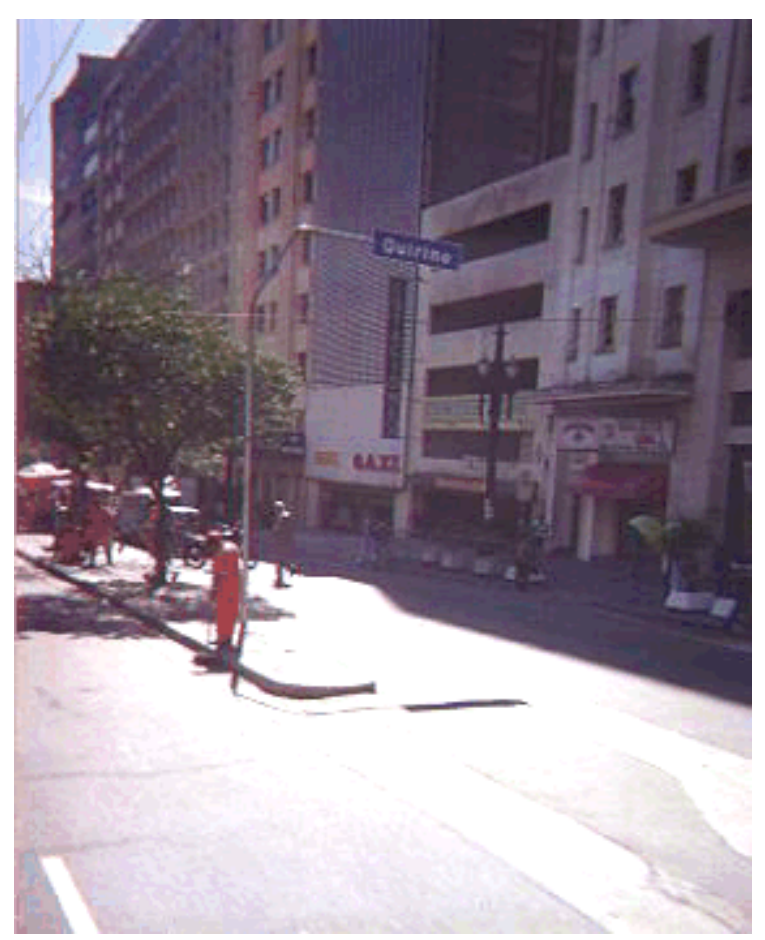

R. Quirino de Andrade, foto de 2000 


\section{HIGIENÓPOLIS}

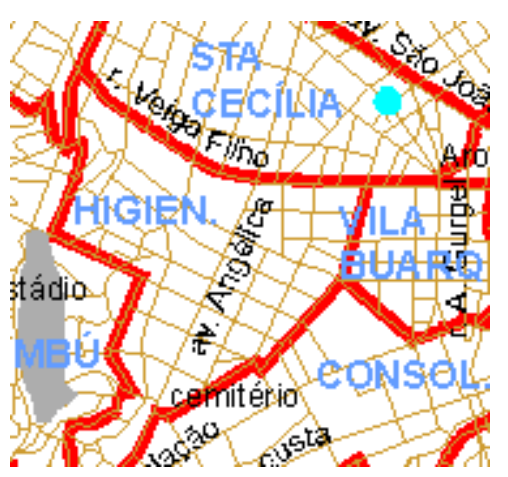

\section{ANTERIOR A 1890}

\section{0-1921}

A região foi escolhida para o loteamento devido a sua altitude elevada, pois, segundo os princípios higienistas da época essas regiões eram consideradas mais salubres (REALE, E. 1982 p.157)(HOMEM, M. 1980 p.34). Em 1897 iniciou-se a ocupação do bairro de Higienópolis, bairro residencial horizontal de elite (HOMEM, M. 1980 p.80). Essa ocupação foi feita principalmente por fazendeiros e primeiros industriais brasileiros, além do elemento anglo-saxão (PONCIANO, L. 1999 p.67).

\section{2-1951}

Nos anos 30 Higienópolis começou a perder prestígio para outros bairros (HOMEM, M. 1980 p.150). No final da década de 30 e principalmente na década de 40 iniciou-se a verticalização residencial (TARALLI, C. 1993 p.124)(HOMEM, M. 1980 p.154)(PONCIANO, L 1999 p.67)(SOMEKH, N. 1989 p.64) e a classe média começou a substituir a elite moradora do bairro (HOMEM, M 1980 p.96 e p.143).

\section{2-1971}

Nesse período intensificou-se a verticalização residencial (CORDEIRO, $\mathrm{H}$. 1980 p.96)(HOMEM, M. 1980 p.164). Houve também um aumento na população israelita (HOMEM, M. 1980 p.163).

\section{2-1999}

Atualmente o bairro é ocupado por inúmeros apartamentos de classe média alta, com algum comércio/serviços nas principais avenidas. No final dos anos 90 foi inaugurado o Shopping Pátio Higienópolis. A construção desse shopping causou polêmica entre os moradores do bairro, pois muitos acreditavam que ele poderia causar danos à qualidade de vida de Higienópolis, contudo, segundo informações dos jornais O Estado de São Paulo e Jornal da Tarde atualmente o Shopping é bem aceito pela população (PONCIANO, L. 1999 p.67)(TARALLI, C. 1993 p.168)(ESP 16/12/95)(JT 05/12/00). 


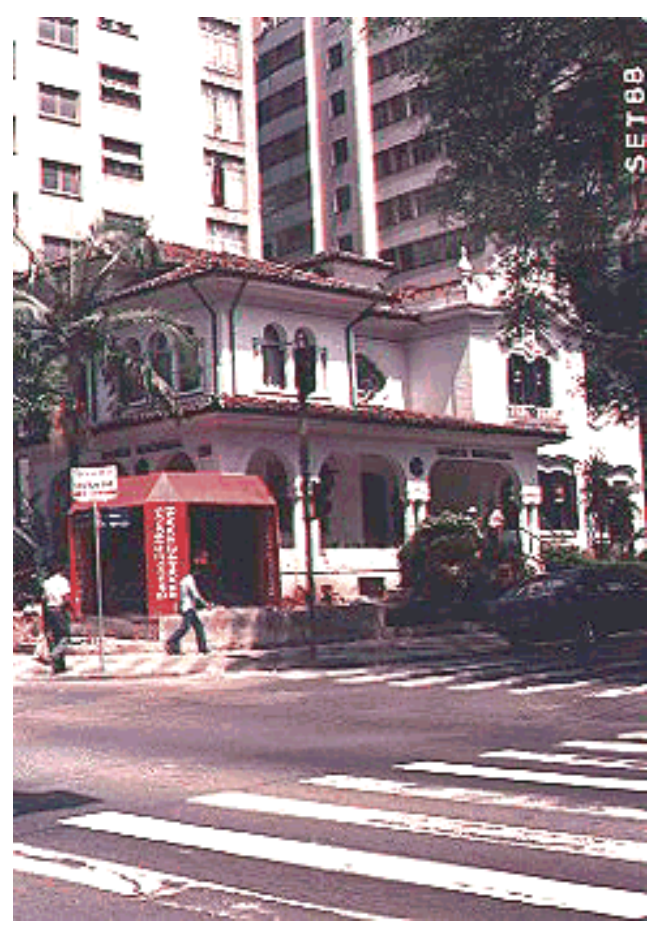

Higienópolis, Avenida Angélica em 1988 


\section{IBIRAPUERA / JD LUSITÂNEA / VILA NOVA CONCEIÇÃO}

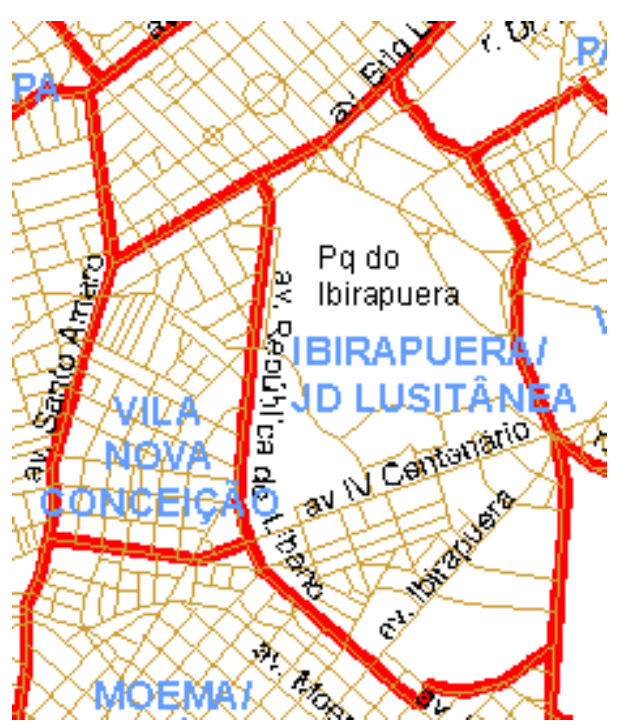

\section{ANTERIOR A 1890}

\section{0-1921}

Nesse período a região era semi-rural com apenas algumas residências (TORRES, M. 1977 p.37 e p.64).

\section{2-1951}

$\mathrm{Na}$ década de 30 era uma área desocupada, havia apenas um conjunto de algumas residências principalmente próximas à área do futuro Parque Ibirapuera, onde havia o viveiro de plantas de Manequinho Lopes (PONCIANO, L. 1999 p.68)(Mapa Sara Brasil 1930).

\section{2-1971}

Na década de 50 já havia uso residencial horizontal de elite em lbirapuera e Jardim Lusitânia. Em Vila Nova Conceição havia ocupação residencial horizontal de classe média (MENDES, R. 1958 p.290)(TORRES, M. 1977 p.106). Em 1954 foi inaugurado o Parque Ibirapuera como parte das comemorações do quarto Centenário da cidade (PONCIANO, L. 1999 p.68). Nos anos 60 iniciou-se a verticalização de Vila Nova Conceição (TARALLI, C. 1993 p.168).

\section{2-1999}

As áreas residenciais de elite mantiveram suas características, tendo havido grande verticalização e aumento do comércio/serviços, principalmente em Vila Nova Conceição (PMSP 2000 V.1 p.44)(PMSP 2000 mapa uso do solo 1999). 
INDIANÓPOLIS / MOEMA

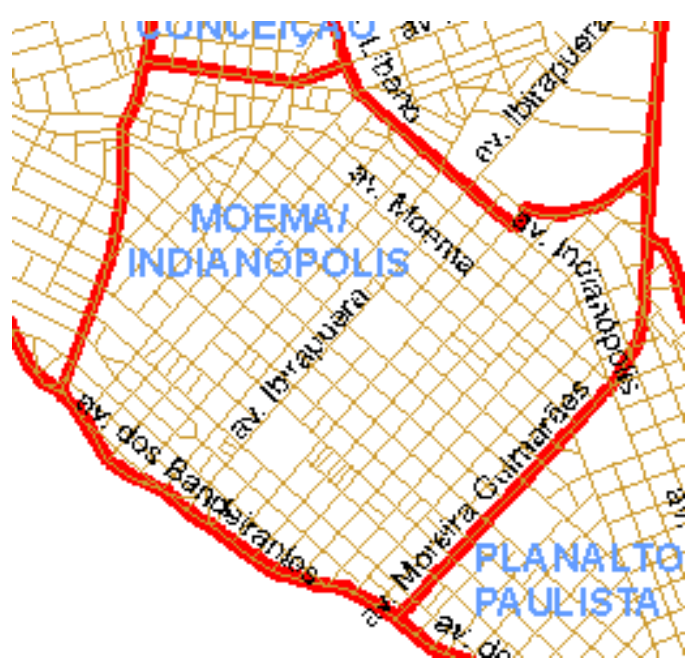

\section{ANTERIOR A 1890}

\section{0-1921}

No final do século XIX era ocupado por chácaras de imigrantes alemães e ingleses. Em 1915 ocorreu o grande loteamento da área, porém seu crescimento foi lento no início (PONCIANO, L. 1999 p.90).

\section{2-1951}

Mapa de 1930 indicava uma ocupação esparsa para a área (MAPA SARA BRASIL 1930). Em 1936 foi inaugurado o aeroporto de Congonhas nas proximidades do bairro (MENDES, R. 1958 p.288). Nos anos 40 o bairro alcançou maior ocupação (MENDES, R. 1958 p.288).

\section{2-1971}

O bairro, considerado de classe média nos anos 50 manteve seu perfil até a proximidade dos anos 70 quando iniciou-se alguma verticalização (SOMEKH, N. 1989 p.106)(CESAD/FAUUSP/PMSP TPCL 1971).

\section{2-1999}

Nesse período o bairro alcançou grande crescimento vertical e desenvolvimento comercial/serviços (TARALLI, C. 1993 p.168)(SOMEKH, N. 1989 p.140)(PMSP 2000 mapa uso do solo 1999). 


\section{ITAIM / VILA OLÍMPIA}

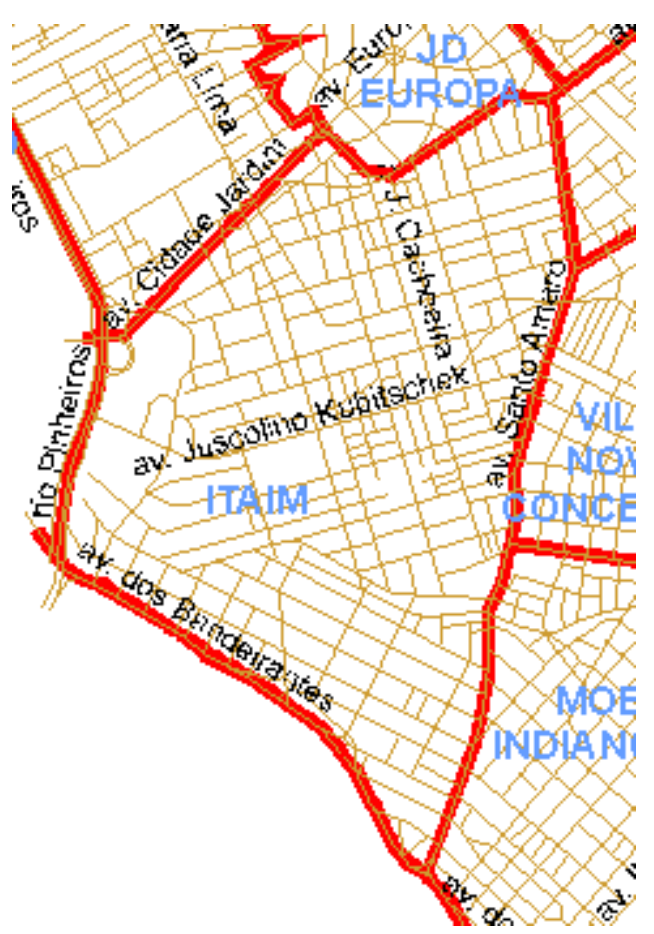

\section{ANTERIOR A 1890}

\section{0-1921}

No início do século XIX o bairro não tinha utilização econômica em razão das inundações (LOPES, H. 1988 p.16). Entre os anos 10 e 20 do século XX surgiram as primeiras ruas, passagem entre as chácaras e os primeiros loteamentos populares (LOPES, H. 1988 p.19)(PONCIANO, L. 1999 p.72). 1922-1951

Entre os anos 20 e 30 a área ainda estava sendo loteada e ocupada por população de baixa renda com alguma classe média, principalmente na Vila Olímpia (MENDES, R. 1958 p.313).

\section{2-1971}

Nos anos 50 e 60 já havia algum comércio no Itaim, principalmente na região da rua João Cachoeira (LOPES, H. 1988 p.69)(MÜLLER, N. 1958 p.167). Nos anos 60 também houve início de verticalização residencial (LOPES, H. 1988 p.74)(TARALLI, C. 1993 p.168).

\section{2-1999}

A partir da década de 70 houve grande aumento da verticalização e do comércio/serviços para classe média e elite (LOPES, H. 1988 p.68, p.69 e p.97)(SOMEKH, N. 1989 p.106)(TARALLI, C. 1993 p.168). Nesse período também houve grande aumento de casas noturnas (CORDEIRO, $\mathrm{H}$. 1980)(PONCIANO, L. 1999 p.72). O prolongamento da avenida Faria Lima contribuiu para o aumento de comércio e serviços principalmente em Vila Olímpia (ESP 09/02/97)(ESP 25/06/00). 


\section{JARDIM AMÉRICA}

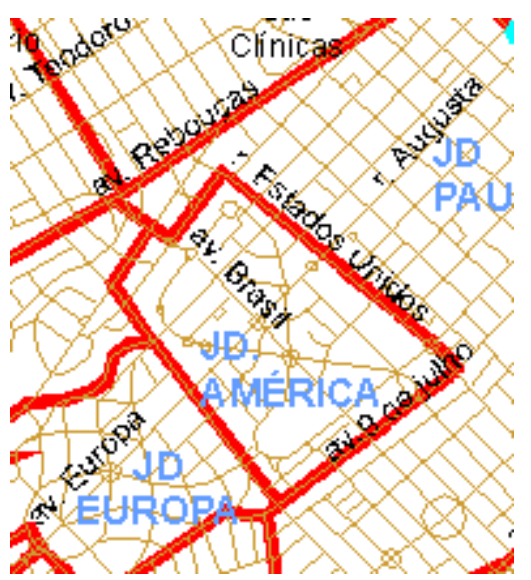

\section{ANTERIOR A 1890}

\section{0-1921}

O bairro foi projetado em 1910 pela Cia City como residencial horizontal de elite e teve crescimento lento (BRUNO, E. 1954 p.951)(HOMEM, M. 1980 p.24)(REALE, E. 1982 p.146 e p.157)(PONCIANO, I. 1999 p.79).

\section{2-1951}

A partir de 1925 intensificou-se a ocupação do bairro (MENDES, R. 1958 p.311)(BACELLI, R. 1982 p.62)(REALE, E. 1982 p.163), o que se consolidou em meados da década de 40 (BACELLI, R. 1982 p.62).

\section{2-1971}

Nesse período o bairro permaneceu como residencial horizontal de elite (CORDEIRO, H. 1980 p.73).

\section{2-1999}

Nesse período o bairro permaneceu com uso residencial horizontal de elite com a presença de corredores comerciais, principalmente comércio e serviços de elite (CORDEIRO, H. 1980 p.73)(BACELLI, R. 1982 p.84)(REALE, E. 1982 p.1999)(PMSP 2000 mapa uso solo 1999). Há uma polêmica entre moradores, como em quase todos os bairros jardins, a respeito da preservação das características residenciais do bairro (ESP 19/07/99). 


\section{JARDIM EUROPA}

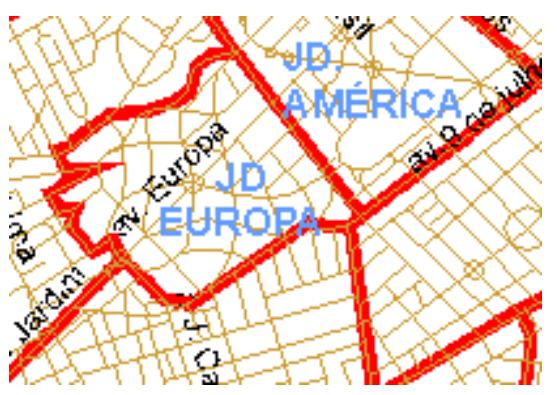

ANTERIOR A 1890

1890-1921

1922-1951

O Jardim Europa foi loteado em 1922 como residencial horizontal de elite alcançando segundo Reale, grande sucesso em suas vendas, principalmente após a instalação da linha de bondes (HOMEM, M. 1980 p.24)(REALE, E. 1982 p.199 e p.204)(BACELLI, R. 1982 p.82).

\section{2-1971}

O bairro permaneceu como residencial horizontal de elite (MENDES, R. 1958 p.311).

\section{2-1999}

Permaneceu residencial de elite com corredores comerciais (REALE, E. 1982 p.211)(PMSP 2000 mapa uso solo 1999). 


\section{JARDIM PAULISTA}

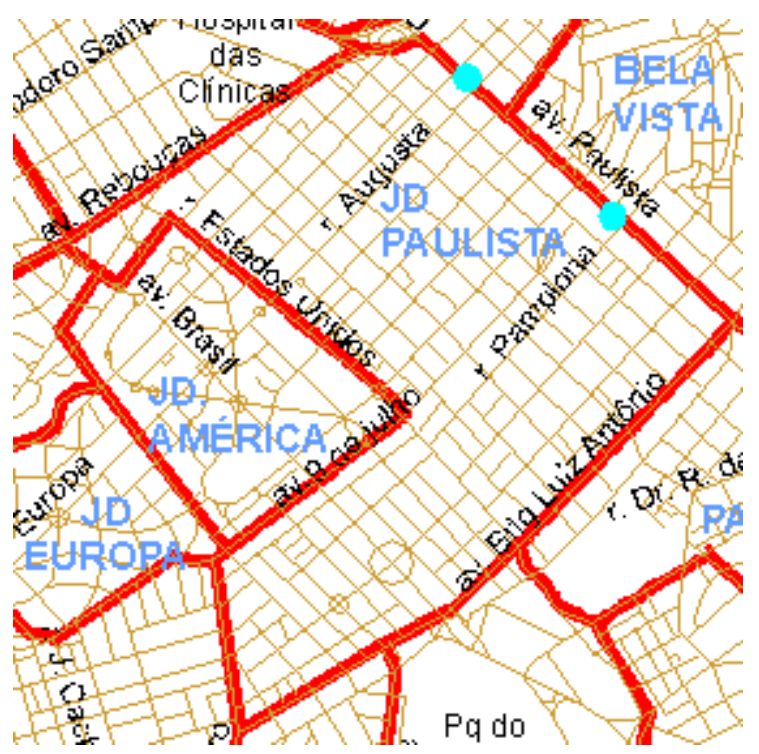

\section{ANTERIOR A 1890}

\section{0-1921}

O bairro nasceu após $1891 \mathrm{com}$ a abertura de transversais e paralelas à Av. Paulista e foi ocupado por uso residencial horizontal de classe média e de classe média alta e elite próximo aos bairros residenciais de elite (REALE, e. 1982 p.130).

\section{2-1951}

Nos anos 40 já se iniciava a verticalização residencial (CORDEIRO, H. 1980 p.80)(SOMEKH, N. 1989 p.79).

\section{2-1971}

Nesse período houve um maior desenvolvimento do comércio/serviços, principalmente nas ruas Augusta e Pamplona, regiões servidas por transporte coletivo (SÃO PAULO (PMSP) 1969 - mapa uso do solo 1968)(CORDEIRO, H. 1980 p.92)(REALE, E. 1982 p.138)(MENDES, R. 1958 p.303)(MÜLLER, N. 1958 p.167) e intensificou-se a verticalização (TARALLI, C. 1993 p.168)(REALE, E. 1982 p.144).

\section{2-1999}

A partir dos anos 70 continuou a verticalização e houve grande aumento do comércio/serviços de elite, áreas próximas ao Jardim América continuaram residenciais (SOMEKH, N. 1989 p.103)(CORDEIRO H. 1980 p.73, p.88 e p.104)(REALE, E. 1982 p.145)(PMSP 2000 mapa uso solo 99). Nos últimos anos, apesar da concorrência dos shoppings, o comércio de elite continua instalado no bairro (JT 26/06/00). 


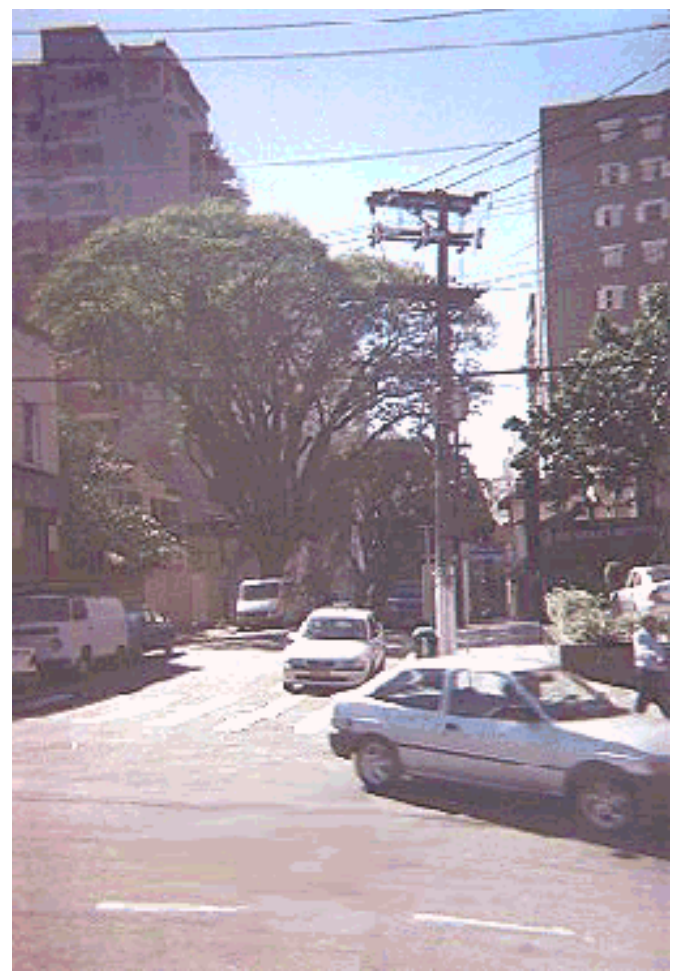

Jardim Paulista, r. Oscar Freire em 2001 


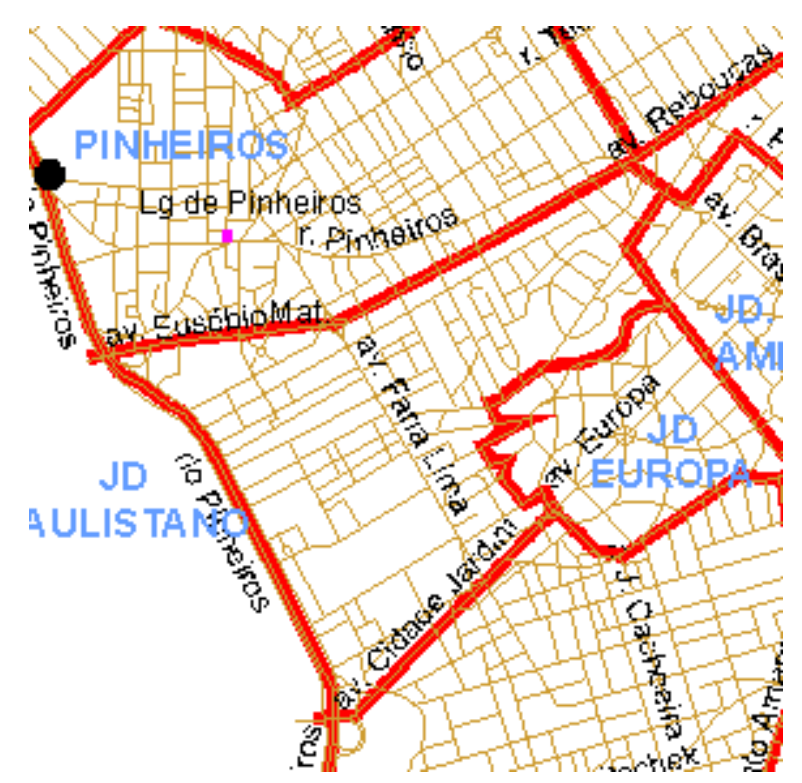

\section{ANTERIOR A 1890}

\section{0-1921}

\section{2-1951}

O bairro nasceu nesse período, aos poucos, sendo a última área a ser loteada aquela nas proximidades do rio Pinheiros após a canalização do mesmo nos anos 40 . O bairro foi ocupado pelo uso residencial de elite e de classe média. (PETRONE, P. 1963 p.84)(MENDES, R. 1958 p.79).

\section{2-1971}

Nos anos 50 permanecia como bairro residencial horizontal de elite e de classe média, já com algum comércio nas principais vias, aquelas servidas por transporte coletivo (CORDEIRO, H. 1980 p.128)(MENDES, R. 1958 p.79). Em 1966 o Shopping Iguatemi foi inaugurado na rua Iguatemi (atual avenida Faria Lima), iniciando a ocupação comercial/serviços dessa avenida (CORDEIRO, H. 1980 p.79 e p.95).

\section{2-1999}

Parte do bairro permaneceu com uso residencial de elite, outra apresenta concentração de apartamentos e comércio/serviços. A avenida Faria Lima apresenta grande concentração de edifícios comerciais desde 1976 (CORDEIRO, H. 1980 p.79)(PMSP 2000 mapa uso solo 1999). Nos anos 90 a avenida Faria Lima teve sua importância no setor de comércio e serviços aumentada, alcançando, segundo o jornal Folha de São Paulo um preço maior do que a avenida Paulista. A avenida também foi prolongada principalmente no trecho dos bairros de Pinheiros e Itaim (FSP 26/07/99). 


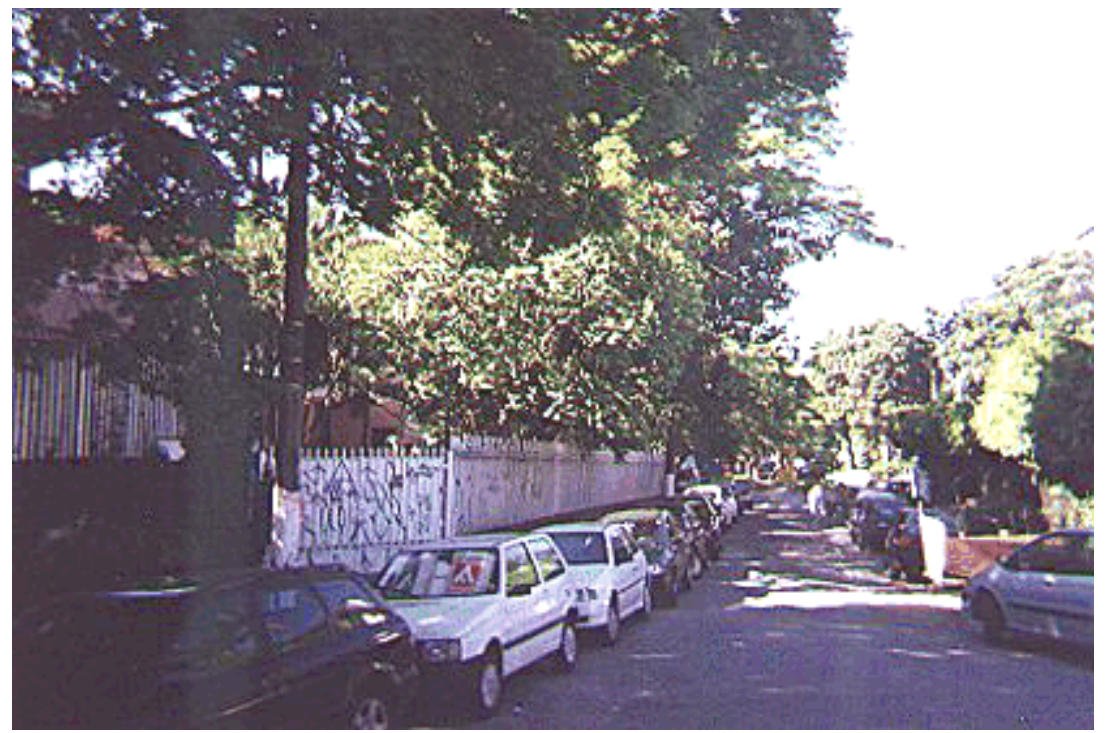

Trecho residencial do Jardim Paulistano. Foto de 2000

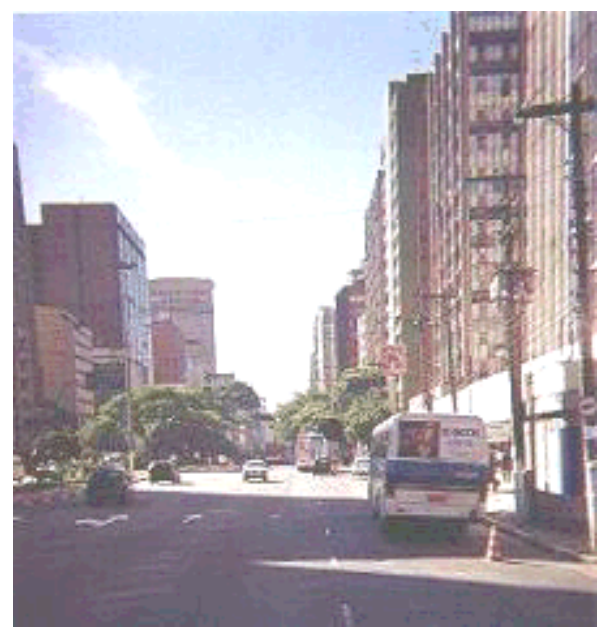

Avenida Faria Lima. Foto de 2000 


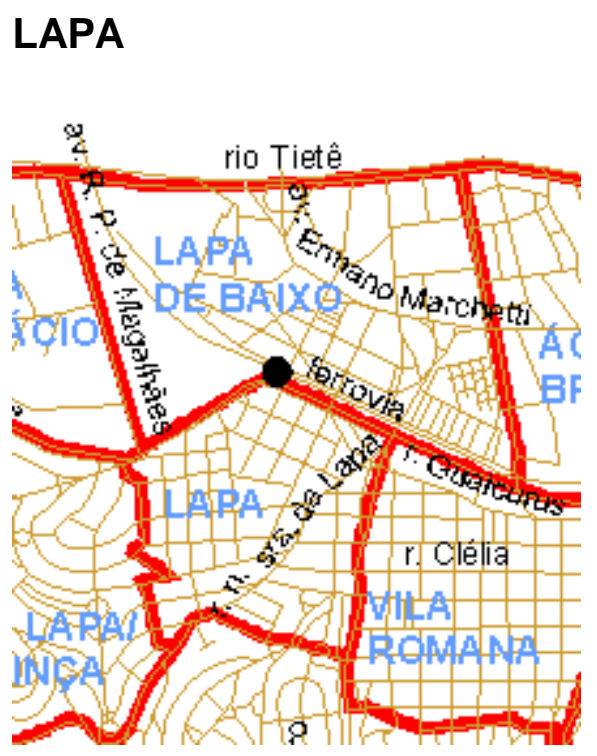

\section{ANTERIOR A 1890}

A ocupação da região da Lapa é antiga, pois desde 1755 já existia uma capela no local. Durante o século XIX a região serviu como ponto de passagem para tropeiros com presença de indústrias artesanais e olarias (SANTOS, W. 1980 p.14 e p.18). Em 1880 a instalação de indústria de vidro nas proximidades do bairro atraiu maior ocupação (SEGATTO, J. 1988 p.15)(PONCIANO, L. 1999 p.83).

\section{0-1921}

Em 1891 houve na região um grande loteamento chamado Gran Burgo da Lapa (SEGATTO, J. 1988 p.17). Em 1898 houve a mudança das oficinas ferroviárias para a região, e houve maior ocupação industrial (SANTOS, W. 1980 p.71). Em 1899 com a inauguração da estação ferroviária iniciou-se alguma atividade comercial nas proximidades dessa estação, principalmente na Lapa de Baixo (SANTOS, W. 1980 p.78)(SEGATTO, J. 1988 p.43). A inauguração de linha de bondes na Lapa favoreceu, segundo Segatto, a instalação do comércio na região (SEGATTO, J. 1988 p.43). No início do século XX intensificou-se a ocupação residencial operária e industrial com alguma presença de classe média, representada em parte pelos funcionários mais graduados da ferrovia (ROLNIK, R. 1997 p.82)(PONCIANO, L. 1999 p.83)(BRUNO, E. 1954 p.955).

\section{2-1951}

A partir das décadas de 20 e 30 intensificou-se o uso industrial e comercial, principalmente na Lapa de Cima (SEGATO, J. 1988 p.43, p.59). No final dos anos 40 o núcleo principal da Lapa se consolidou como subcentro comercial/serviços popular (VILLAÇA, F. 1988 p.326).

\section{2-1971}

Nos anos 50 além da continuação das funções industrial, comercial/serviços e residencial horizontal iniciou-se a verticalização residencial (SOMEKH, N. 1989 p.84)(MÜLLER, N. 1958p.167)(TARALLI, C. 1993 p.168). Em 1954 foi construído o mercado da Lapa, reforçando seu caráter comercial (SEGATTO, J. 1988 p.43).

1972-1999

Nesse período a região perdeu residências horizontais e indústrias, havendo 
aumento de verticalização. O uso comercial/serviços estabilizou-se (SEGATTO, J. 1988 p.60)(PMSP 2000 mapa uso solo 1999)(CESAD/FAUUSP/TPCL 1971/TPCL 1990).

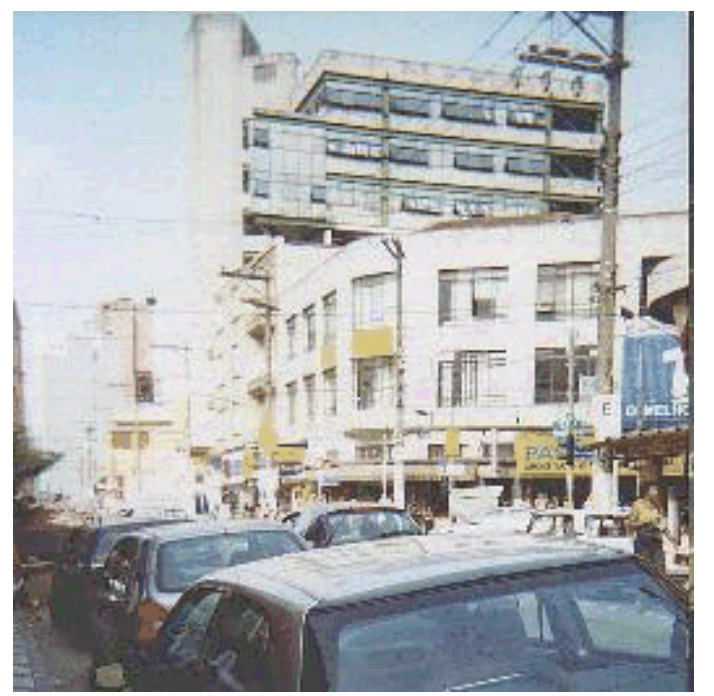

O centro da Lapa, foto de 2001 


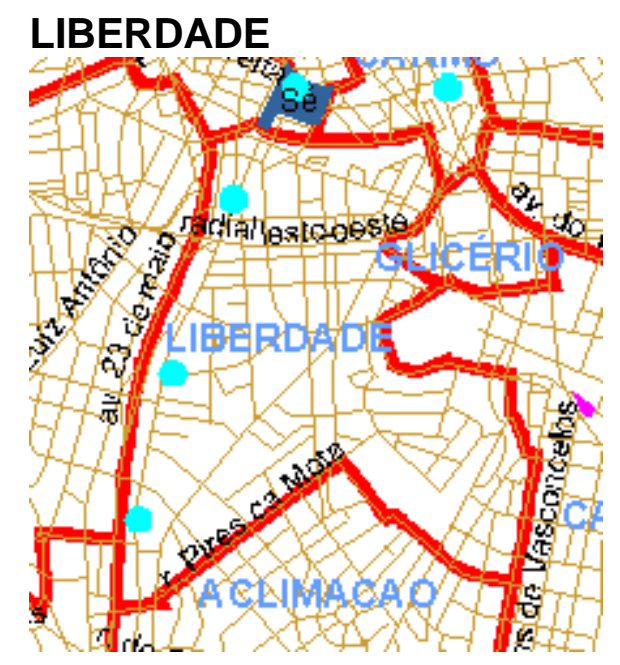

\section{ANTERIOR A 1890}

A região sempre foi importante devido a sua localização estratégica, cortada pelo Caminho do Mar (GUIMARAES, L. 1979 p.14). Entre 1754 e 1813 funcionou na região da Liberdade, então afastada do núcleo urbano a Casa da Pólvora (GUIMARÃES, L. 1979 p.18). No bairro também ficava o Pelourinho (GUIMARAES, L. 1979 p.14). Em meados do século XIX havia na região casas de bom padrão que perduraram até o início do último quartel do século XIX (BRUNO, E. 1954 p.1042)(TARALLI, C. 1993 p.192)(VILLAÇA, F. 1998 p.262). Com a abertura da nova estrada para o litoral, a Estrada do Vergueiro houve maior ocupação da região. No bairro também houve uma feira de madeiras e um matadouro (MASAROLO, p. 1971 p.51). No final do século XIX segundo Homem, a região era ocupada por classe média (HOMEM, M. 1980 p.24) e também pensões (GUIMARÃES, L. 1979 p.151).

\section{0-1921}

No início do século, segundo Guimarães já havia algum comércio/serviços na avenida Liberdade, embora o uso predominante ainda fosse residencial (GUIMARÃES, L. 1979 p.64 e p.60).

\section{2-1951}

Nesse período, segundo Feldman, além dos outros usos, havia cortiços e prostituição na Liberdade (FELDMAN, S. 1989 mapa 1). Em 1939 se instalaram os primeiros japoneses no bairro (GUIMARÃES, L. 1977 p.107). 1952-1971

Nos anos 50 iniciou-se a verticalização residencial de classe média (SOMEKH, N. 1989 p.84)(TARALLI, C. 1993 p.168)(MENDES, R. 1958 p.275) com aumento de comércio e serviços (MENDES, R. 1958 p.277). Nos anos 60, segundo Feldman, a região continuava a apresentar prostituição e cortiços (FELDEMAN, S. 1989 p.105).

\section{2-1999}

Segundo Guimarães, o metrô, na década de 70, remodelou o bairro (GUIMARAES, L. 1979 p.91). A partir dos anos 70 o bairro continuou sua verticalização (SOMEKH, N. 1989 p.103)(GUIMARÃES, L. 1979 p.24) e houve aumento do comércio/serviços. Além da grande colônia japonesa, instalaramse no local os coreanos e o bairro começou a aproveitar a origem oriental de sua população como elemento de atração turística (GUIMARÃ̃ES, L. 1979 p.108)(PONCIANO, L. 1999 p.85)(PMSP 2000 mapa uso solo 99). 


\section{LUZ}

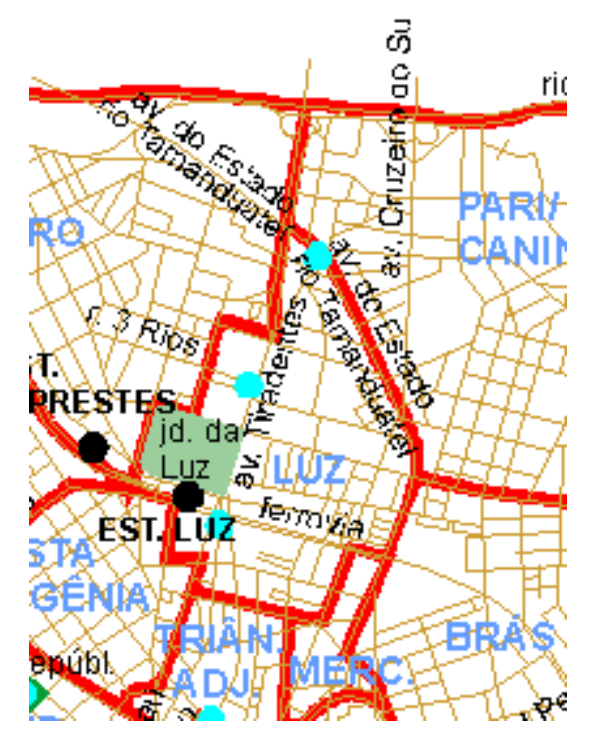

\section{ANTERIOR A 1890}

A região da Luz já possuía alguma ocupação desde o século XVI quando ali foi construída a Capela para Nossa Senhora da Luz do Guarepe (GUIMARÃES, L. 1977 p.23)(PONCIANO, L. 1999 p.87). A região também era caminho para as tropas (JORGE, C. 1988 p.51). Houve também nesse período anterior a 1890 a feira de Pilatos (ICl, 1994 v. 9 p.9). Em 1799 foi construído o Quartel dos Voluntários Reais (JORGE, C. 1988 p.53). Em 1825 foi inaugurado o Jardim da Luz (GUIMARÃES, L. 1977 p.39 e p.57). Segundo Bruno, desde meados do século XIX a região era ocupada por residências de bom padrão (BRUNO, E. 1954 p.1042)(HOMEM, M. 1980 p.24). Em 1867 após a inauguração da ferrovia e da estação da Luz houve um aumento do comércio/serviços e de hotéis (JORGE, D. 1988 p.110, p.113 E p.114)(MENDES, R. 1958 p.194).

\section{0-1921}

No final do século XIX foram construídos novos edifícios como o Quartel e o Hospital (ICl 1994 v9 p.9). No início do século XX o Jardim da Luz já não era tão freqüentado, principalmente pela elite, como no período anterior (GUIMARÃES, L. 1977 p.61).

\section{2-1951}

Em 1927 e 1938 ocorreu o afastamento de algumas instituições religiosas do bairro (JORGE C. 1988 p.79). Nos anos 40 o acesso ao bairro sofreu significativa melhoria com a conclusão das obras da avenida Tiradentes (SANTOS, M. 2000 p.105). Após essa década houve um aumento do comércio/serviços no bairro (ICl 1994 v.9 p.19).

\section{2-1971}

Nos anos 50 o uso do solo da região foi descrito como bem diversificado, com aptos, comércio/serviços e residências (ICl 1994 V.9 p.21)(MENDES, R. 1958 p.205). Mapa do Plano Urbanístico Básico de 1968 apontava grande presença do uso comércio/serviços no bairro, tendência essa confirmada pelos dados do TPCL 1971 (SÃO PAULLO (PMSP) 1969 - mapa uso solo 1968)(CESAD/FAUUSP/PMSP TPCL 1971).

\section{2-1999}

Segundo publicação do Instituto Cultural Itaú, o metrô na década de 70 
melhorou a acessibilidade da região (ICl 1994 v.9 p.9). Mapa do uso do solo de 1999 elaborado pela Prefeitura apontou o caráter de uso do solo misto do bairro, mas principalmente com forte presença de comércio e serviços (PMSP/2000 mapa uso do solo 1999). 


\section{MOÓCA, PARQUE DA MÓOCA/VILA MONUMENTO}

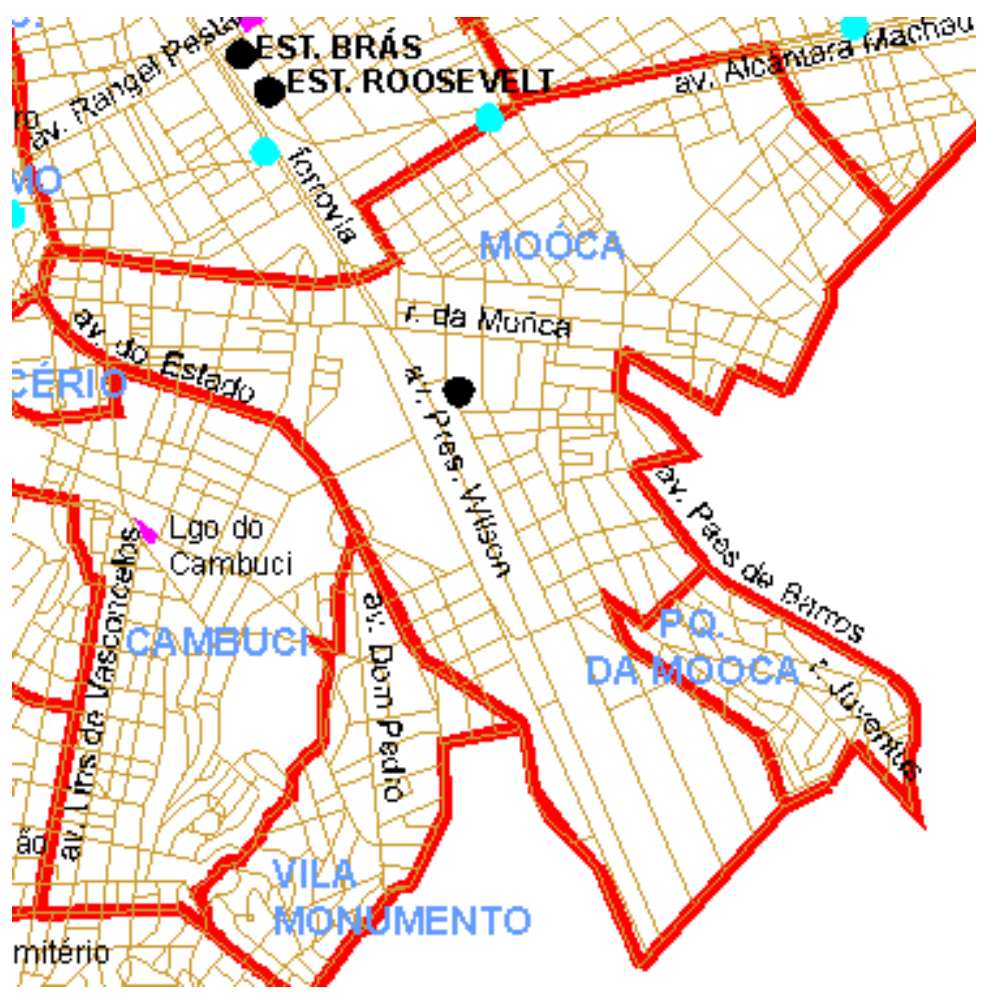

\section{ANTERIOR A 1890}

Segundo Andrade, a urbanização na zona leste de São Paulo intensificou-se após 1867 com a inauguração da ferrovia, com a ocupação da Moóca e região por uso residencial operário (inclusive cortiços) e uso industrial (ANDRADE, M. 1994 p.98). Em 1877 já havia linha de bondes para o hipódromo instalado na região. (PONCIANO, L. 1999).

\section{0-1921}

Nesse período o bairro já estava mais ocupado, com indústrias, principalmente de bens de consumo e uso residencial horizontal operário, com forte presença de imigrantes italianos, e, em menor número, espanhóis (ANDRADE, M. 1994 p.101 e p. 227)(VILLAÇA, F. 1998 p.195)(PONCIANO, L. 1999 p.91)(HOMEM, M. 1980 p.25)(MENDES, r. 1958 p.236).

\section{2-1951}

Nesse período o bairro permaneceu como industrial e residencial operário, com grande crescimento industrial até a década de 50, havendo ainda algum uso residencial de classe média, principalmente após os anos 20 (MENDES, R. 1958 p.271)(ANDRADE, M. 1991 p.175).

\section{2-1972}

Nesse período, além do uso residencial operário e industrial, também havia classe média, principalmente em Vila Monumento (MENDES, R. 1958 p.260). Surgiram também os primeiros apartamentos. A construção da Radial Leste nos anos 50, segundo Andrade, alterou a estrutura viária da Moóca, separando-a do Brás (ANDRADE, M. 1991 p.230). Segundo Feldman nos anos 60 ainda havia cortiços no bairro (FELDMAN, S. 1989 p.105). Dados do TPCL 1971 apontavam verticalização residencial principalmente em Vila Monumento e Parque da Moóca (CESAD/FAUUSP/PMSP TPCL 1971). 
1972-1999

A principal característica desse período é o declínio do uso industrial com aumento do uso comércio e serviços e apartamentos (ANDRADE, M. 1994 p.97)(PMSP 2000 mapa uso do solo 1999). 


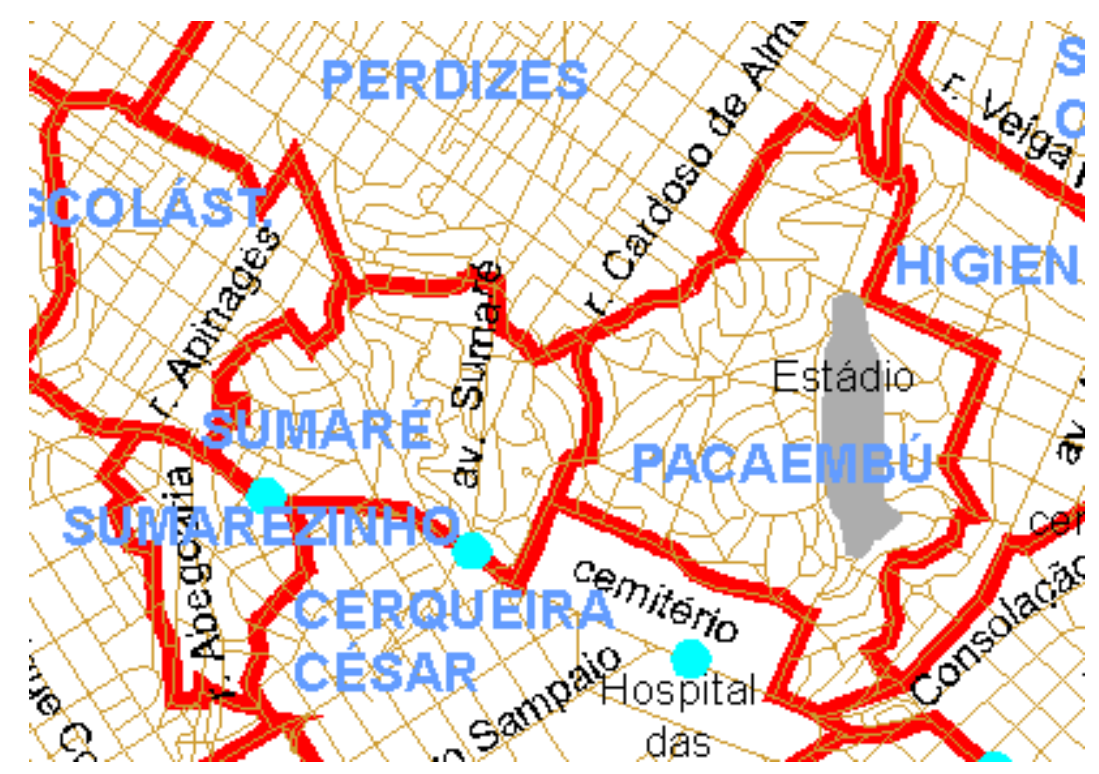

\section{ANTERIOR A 1890}

\section{0-1921}

\section{2-1951}

Esse bairro nasceu a partir de um loteamento residencial horizontal de elite promovido pela Cia City concluído no final dos anos 20 (MENDES, R. 1958 p.341)(HOMEM, M. 1980 p.146). Sua ocupação, a partir dos anos 30, foi lenta (MENDES, R. 1958 p.341). Na década de 30, no início da avenida Alfonso Bovero, no Sumaré, próximo ao bairro de Campos de Escolástica foi inaugurada uma estação de rádio, devido à elevada altitude da região (PONCIANO, L. 1999 p.122). Em 1936 foi dado início à construção do Estádio do Pacaembú, o que, segundo Mendes, contribuiu para a maior ocupação do bairro (MENDES, R. 1958 p.341).

\section{2-1971}

Nesse período a região estava mais ocupada, mas mantendo suas características de uso residencial de elite. O Sumarezinho, próximo à Vila Madalena apresentava, em sua maioria residências de classe média alta (MENDES, R. 1958 p.342). Em 1950 foi inaugurado um estúdio de televisão junto a estação de rádio no Sumaré (PONCIANO, L. 1999 p.122). 1972-1999

O bairro permaneceu como residencial horizontal de elite (PMSP 2000 mapa uso solo 1999). A preservação de suas características residenciais exigiu seu tombamento (ESP 20/02/91). 


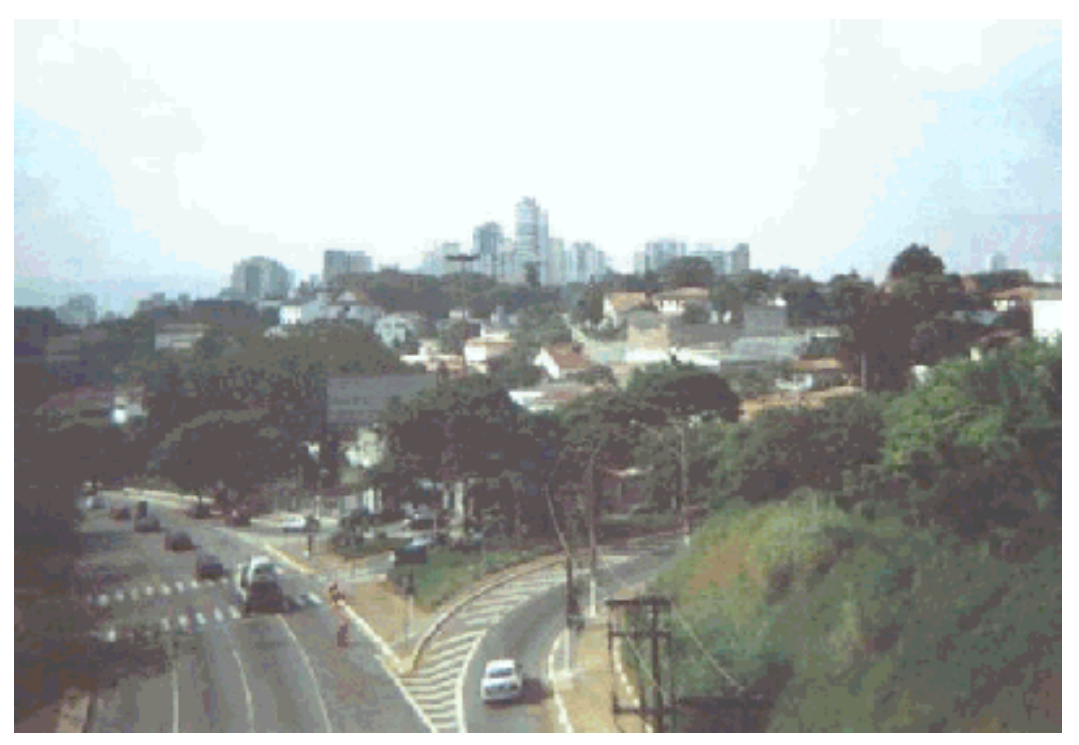

Pacaembú / Sumaré, avenida Sumaré. Foto de 2001 


\section{PARAÍSO}

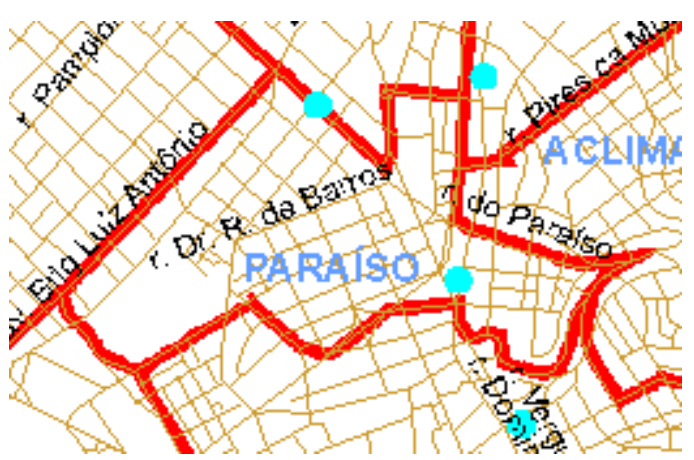

\section{ANTERIOR A 1890}

A região do Paraíso localizou-se em área estratégica da cidade, devido a sua proximidade com o Caminho do Mar. Segundo Ponciano, o bairro Paraíso surgiu em $1880 \mathrm{com}$ a divisão das chácaras que existiam na região (PONCIANO, L. 1999 p.96).

\section{0-1921}

Com a inauguração da avenida Paulista em 1891 e a implantação de linha de bondes nessa avenida houve maior ocupação do bairro, como residencial horizontal de classe média, havendo também algumas residências de elite (PONCIANO, L. 1999 p.96)(MENDES, R. 1958 p.275)(TOLEDO, B. 1990 p.14). 1922-1951

Após a década de 40 o bairro começou a sofrer processo de verticalização residencial (SOMEKH, N. 1989 p.79). Em 1949 foi inaugurada a loja de departamentos da Sears (TOLEDO, B. 1990 p.20).

\section{2-1971}

Se nos anos 50 o bairro do Paraíso ainda era pouco verticalizado e comercial/serviços (MENDES, R. 1958 p.277) esses usos se intensificaram nas décadas subsequentes (SOMEKH, N. 1989 p.103)(CESAD/FAUUSP/PMSP/TPCL 1971).

\section{2-1999}

Após a década de 70 houve grande crescimento da verticalização e do comércio/serviços. A antiga loja de departamentos da Sears foi transformada no Shopping Paulista (PMSP 2000 mapa uso do solo 1999)(CESAD/FAAUSP/PMSP/TPCL 1971)(TOLEDO, B. 1990 p.20). 


\section{PERDIZES}

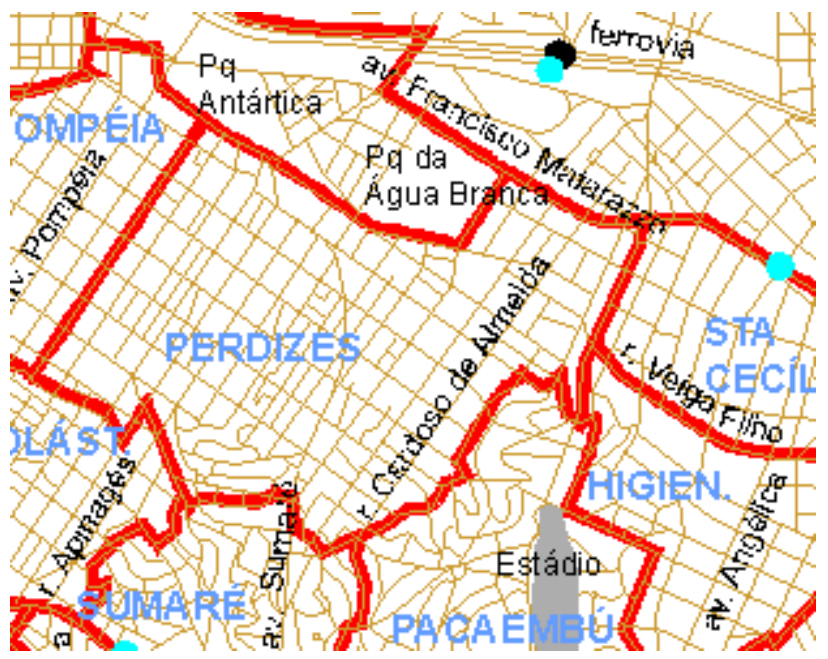

\section{ANTERIOR A 1890}

No último quartel do século XIX já havia um pequeno povoado em meio às chácaras, habitado por pessoas humildes (PACHECO, J. 1982 p.47 e p.208). A partir de 1880 o bairro começou a ser mais ocupado, também por residencial horizontal de classe média (TARALLI, C. 1993 p.82).

\section{0-1921}

Ainda pequeno no final do século XIX e com presença de uso residencial horizontal de classe média (PACHECO, J. 1982 p.72)(VILLAÇA, f. 1998 p.112) o bairro sofreu sua maior expansão a partir de 1915 (PONCIANO, L. 1999 p.102).

\section{2-1951}

No início desse período o bairro ainda se encontrava em fase de expansão (MENDES, R. 1958 p.374). Após os anos 40 começou a ocorrer alguma verticalização (SOMEKH, N. 1989 p.79). Em 1946 foi inaugurada a PUC (universidade) trazendo maior movimento para o bairro (PACHECO, J. 1982 p.188).

\section{2-1971}

Nos anos 50 o bairro é descrito por Mendes como residencial horizontal de classe média, com algum comércio/serviços e apartamentos (MENDES, R. 1958 p.335, p.337 e p.339). Segundo Pacheco a partir de 1957 intensificou-se a verticalização residencial (PACHECO, J. 1982 p.215).

\section{2-1999}

Segundo Pacheco durante os anos 70 o bairro sofreu grande verticalização residencial com presença de comércio/serviços, sem ser, contudo, um pólo comercial/serviços (PACHECO, J. 1982 e p.205). 


\section{PINHEIROS}

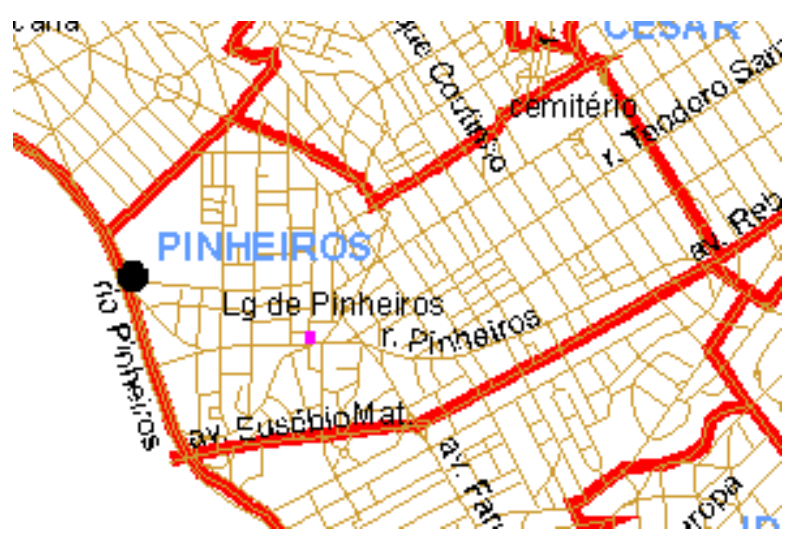

ANTERIOR A 1890

A ocupação de Pinheiros é antiga, pois desde a fundação de São Paulo já se conhecia a aldeia de índios instalada onde a travessia do rio Pinheiros era mais fácil (PETRONE, P. 1963 p.23). Segundo Petrone, no final do século XVIII Pinheiros já havia deixado de ser uma aldeia indígena para se tornar um pequeno povoado caipira. Havia também na região muitos louceiros

(PETRONE, P. 1963 p.97)(REALE, E. 1982 p.68). Segundo Reale, no início do século XIX Pinheiros já funcionava como ponto central de área rural (REALE, E. 1982 p.68).

\section{0-1921}

Em 1890, segundo Reale, Pinheiros também funcionava como pouso de tropeiros, havendo ainda olarias e carvoarias, com presença de população de origem italiana (REALE, E. 1982 p.68)(PETRONE, P. 1963 p.63). Em 1907 a função de centro de área rural foi reforçada graças a inauguração do Mercado de Pinheiros. Segundo Reale o bairro sofreu maior ocupação após a extensão da linha de bondes (PETRONE, P. 1963 p.100)(REALE, E. 1982 p.72 e p.73).

\section{2-1951}

$\mathrm{Na}$ década de 20 o desenvolvimento da região se intensificou, com aumento de uso residencial e o bairro passou a funcionar como subúrbio-dormitório. Nessa década também foi inaugurada a Hípica (PONCIANO, L. 1999 p.103)(PETRONE, P. 1963 p.101 e p.123), e a Cooperativa de Cotia em 1927(REALE, E. 1982 p.80). Em 1943, com o término da retificação do rio Pinheiros, as várzeas do bairro foram urbanizadas e houve a implantação da ferrovia (AMARAL, A. 1985 p.86)(PETRONE, P. 1963 p.84)(ZMITROWICZ, W. 1979 p.111). No final dos anos 40 Pinheiros já era um subcentro comercial importante (VILLAÇA, F. 1998 p.326). Após os anos 40 iniciou-se alguma verticalização (SOMEKH, N. 1989 p.79).

\section{2-1971}

Nos anos 50 houve aumento do comércio/serviços. Para Müller já nessa época Pinheiros era subcentro comercial/serviços importante (MÜLLER, N. 1958 p.167)(AMARAL, A. 1985 p.115). Nos anos 60 e 70 ainda havia forte presença de uso residencial horizontal de classe média e modesta (PETRONE, P. 1963 p.123, p.124 e p.127)(CESAD/FAUUSP/PMSP TPCL 1971).

\section{2-1999}

A partir dos anos 70 intensificou-se o crescimento vertical e do uso comércio e serviços (TARALLI, C. 1993 p.168)(SOMEKH, N. 1989 p.140) (PMSP 2000 
mapa uso solo 1999).

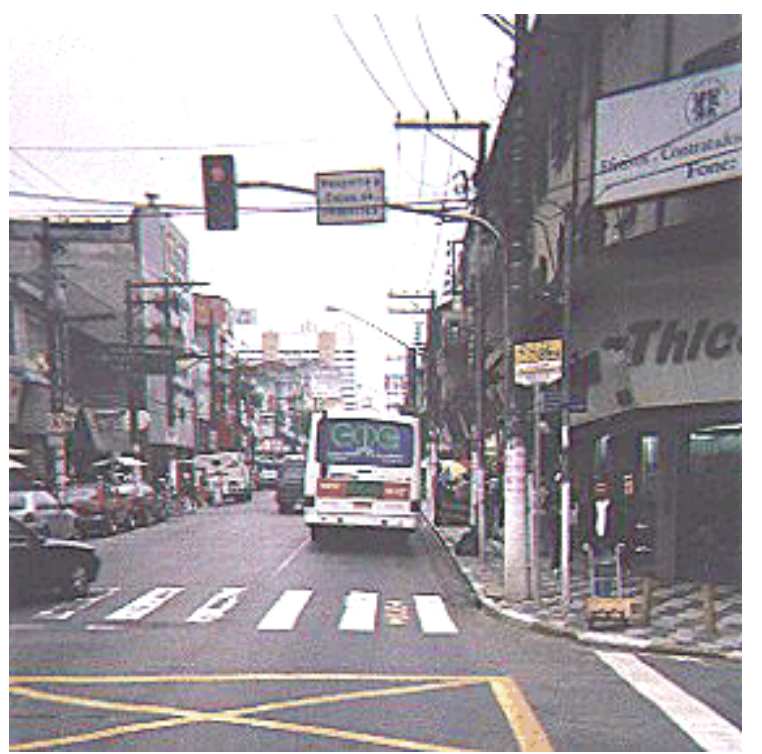

Rua Teodoro Sampaio, bairro de Pinheiros. Foto de 2000 


\section{PLANALTO PAULISTA}

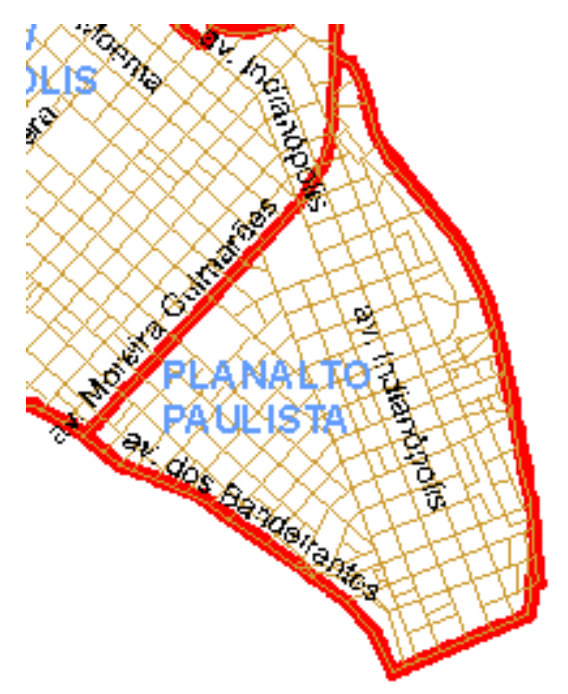

\section{ANTERIOR A 1890}

$$
\text { 1890-1921 }
$$

\section{2-1951}

O bairro foi loteado na década de 20, pois planta de 1924 já indicava sua localização (Planta da Cidade de São Paulo mostrando todos os arrabaldes e terrenos arruados 1924).

\section{2-1971}

Planalto Paulista começou a ser mais ocupado a partir dos anos 50, como residencial de classe média alta, com grande presença de sírios e israelitas (PONCIANO, L. 1999 p.105)(TARALLI, C. 1993 p.167).

\section{2-1999}

Continua como residencial horizontal de classe média alta, com presença de comércio local em algumas avenidas (PMSP 2000 mapa uso solo 1999). 


\section{POMPÉIA}

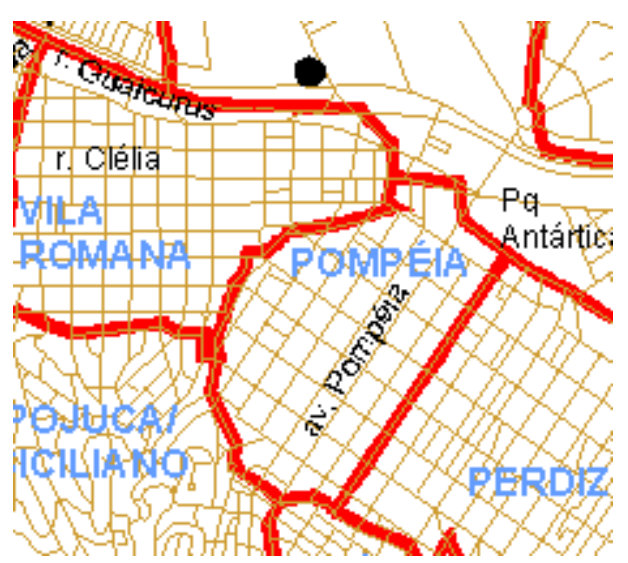

\section{ANTERIOR A 1890}

\section{0-1921}

Em 1914 já se encontrava loteada como residencial horizontal popular e de classe média (MENDES, R. 1958 p.349).

\section{2-1951}

A partir dos anos 30 intensificou-se sua ocupação (MENDES, R. 1958 p.349). 1952-1971

Nos anos 50 foi descrita por Mendes com presença de uso residencial horizontal de classe média e modesta com algumas indústrias e pequeno comércio (MENDES, R. 1958 p.350). No final desse período já havia alguma verticalização (CESAD/FAUUSP/PMSP/TPCL 1971).

1972-1999

Nesse período sofreu verticalização residencial e diminuição do uso industrial com aumento de comércio e serviços (ABRAHÃO, K. 31/08/97 ESP)(PMSP 2000 V.1 p.29)(PMSP/2000 mapa uso do solo 1999).

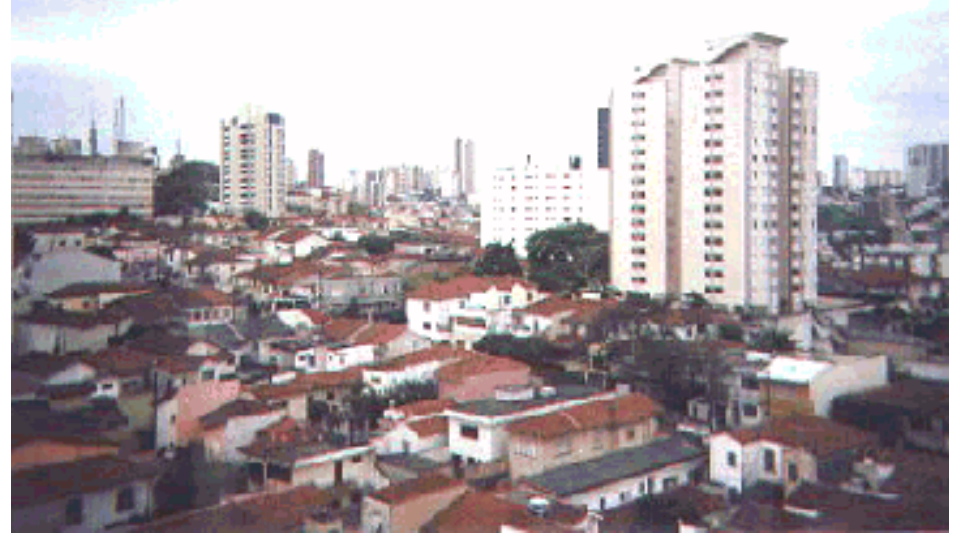

Pompéia, foto de 1999 


\section{SANTA CECÍLIA}

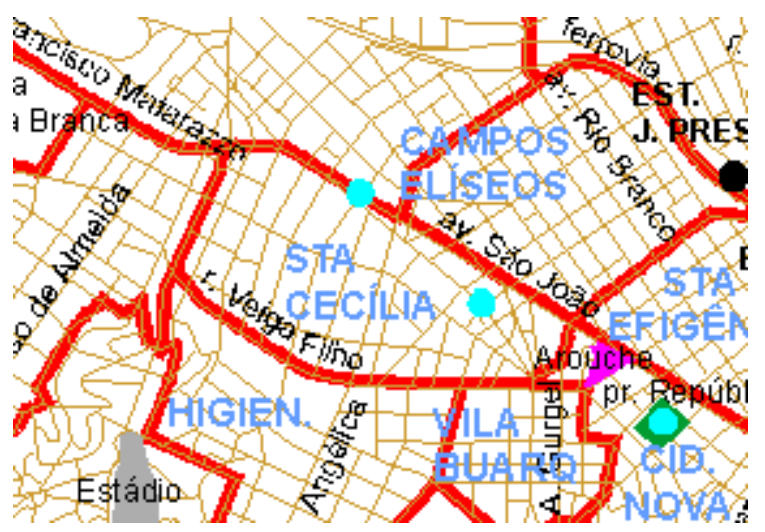

\section{ANTERIOR A 1890}

A ocupação da área é antiga, pois em 1860 já havia sido construída uma capela (PONCIANO, L. 1999 p.110).

\section{0-1921}

Santa Cecília foi loteada em fins do século XIX e teve ocupação de uso residencial horizontal de classe média (HOMEM, M. 1980 p.24) e residencial de bom padrão nas proximidades da avenida São João (VILLAÇA, F. 1998 p.195). No início do século houve algum desenvolvimento comercial nas proximidades do bairro de Higienópolis (HOMEM, M. 1980 p.158). Entre 1910 e 1920 algumas áreas ainda estavam sendo ocupadas (MENDES, R. 1958 p.328).

\section{2-1951}

No final da década de 30 e década de 40 iniciou-se a verticalização do bairro (TARALLI, C. 1993 p.124)(SOMEKH, N. 1989 p.64).

\section{2-1971}

Nesse período o crescimento vertical e comercial/serviços se intensificou (MENDES, R. 1958 p.329)(HOMEM, M. 1980 p.162).

\section{2-1999}

Na década de 70 foi construído o elevado Costa e Silva (Minhocão), que ajudou a deteriorar as condições ambientais do bairro, segundo Cordeiro (CORDEIRO, H. 1980 p.75). 


\section{SANTA EFIGÊNIA}

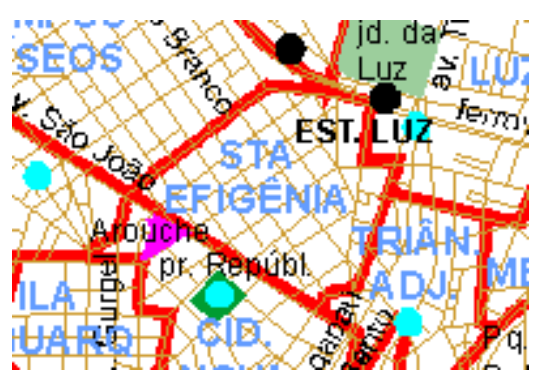

\section{ANTERIOR A 1890}

Em 1720 já existia na região a igreja de Nossa Senhora da Conceição de Santa Ifigência (JORGE, C. 1999 p.61).

A região de Santa Efigênia começou a ser urbanizada no início do século XIX (PONCIANO, L. 1999 p.109)(HOMEM, M. 1980 p.24)(MENDES, R. 1958 p.191). Em meados do mesmo século havia muitas residências de bom padrão no bairro (JORGE, C. 1999 p.85)(BRUNO, E. 1954 p.1042)(TARALLI, C. 19993 p.192)(VILLAÇA, F. 1998 p.268). Com a inauguração da ferrovia nas proximidades em 1867 começou a haver maior comércio/serviços (MENDES, R. 1958 p.194).

\section{0-1921}

A inauguração do viaduto de Santa Efigênia em 1913 começou a atrair maior movimento para o bairro, por facilitar o acesso (PONCIANO, L. 1999 p.109)(JORGE, C. 1999 p.166).

\section{2-1951}

Em 1922 foi inaugurado o correio na avenida São João, na Cidade Nova, divisa com Santa Efigênia (JORGE, C. 1999 p.181). Já nesse período havia cortiços e prostituição no bairro (FELDMAN, S. 1989 mapa 1). No final da década de 30 e 40 iniciou-se a verticalização (TARALLI, C. 1993 p.124) 1952-1971

Nos anos 50 o bairro continuou sua verticalização, mas segundo Müller, nessa década o comércio/serviços ainda era pequeno (MÜLLER, N.1958 p.180). Nos anos 60 a inauguração da Rodoviária nas proximidades provocou o aumento de hotéis, convivendo lado a lado com cortiços e casas noturnas (FELDMAN, S. 1989 p.122, p.128). Dados do TPCL 1971 indicaram forte presença de comércio em 1971 (CESAD/FAUUSP/PMSP/1971).

\section{2-1999}

Nesse período a área pode ser caracterizada com forte presença de uso comercial/serviços e verticalização. Há também a presença de ambulantes e comércio/serviços de informática (PONCIANO, L. 1999 p.109)(PMSP 2000 mapa uso solo 1999). 


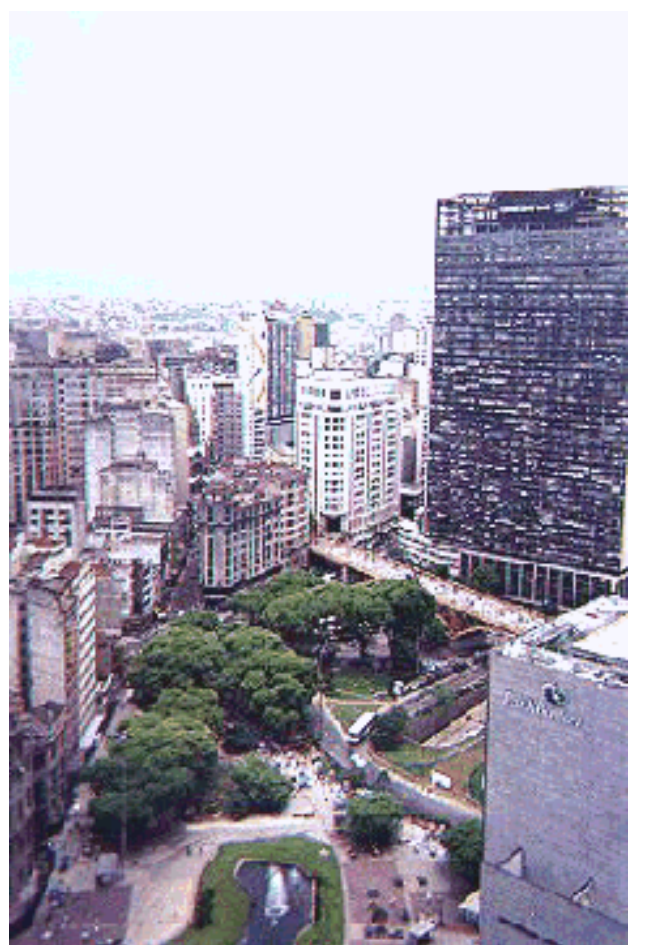

Santa Efigênia, próximo ao viaduto do mesmo nome. Foto de 2000 


\section{VILA BUARQUE}

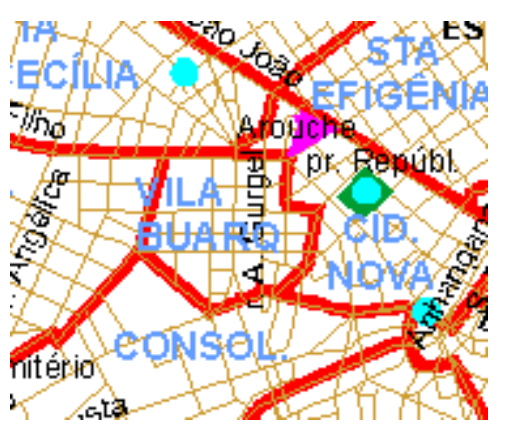

\section{ANTERIOR A 1890}

Vila Buarque foi loteada em 1880 como residencial horizontal classe média (HOMEM, M. 1980 p.61).

\section{0-1921}

A ocupação predominante do bairro foi do uso residencial horizontal de classe média (MENDES, R. 1958 p.324), embora para Torres, com alguns cortiços (TORRES, M. 1977 p.162). Para Villaça havia também uso residencial de bom padrão (VILLAÇA, F. 1998 p.195), opinião com a qual também concorda Bruno (BRUNO, E. 1954 p.947).

\section{2-1951}

A verticalização residencial teve início no final da década de 30 e 40 (TARALLI, C. 1993 p.124). Já nesse período havia alguns cortiços e prostituição no bairro (FELDMAN, S. 1989 mapa 1).

\section{2-1971}

Nos anos 50 o bairro foi invadido pela prostituição (HOMEM, M. 1980 p.165) e o crescimento vertical continuou (SOMEKH, N. 1989 p.81)(MENDES, R. 1958 p.324 e p.325)(PONCIANO, L. 1999 p.127). Nesse período o bairro foi ocupado, principalmente a partir das proximidades do centro histórico da cidade com casas noturnas e prostituição, de alto nível (FELDMAN, S. 1989 p.140).

\section{2-1999}

Nesse período o bairro se consolidou como verticalizado, com forte presença de comércio e serviços, vida noturna intensa, com de muitos teatros (CORDEIRO, H. 1980 p.103, p.144 e p.146)(PMSP 2000 mapa uso solo 1999). A partir dos anos 70 , segundo Feldman, as casas noturnas se popularizaram (FELDEMAN, S. 1989 p.140). 


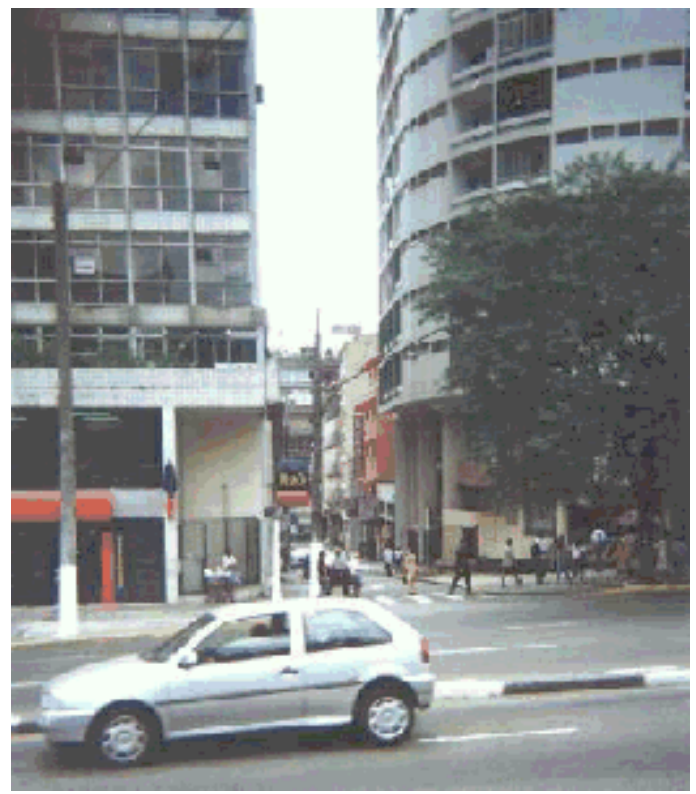

Vila Buarque. Foto 2001 


\section{TRIÂNGULO E ADJACÊNCIAS}

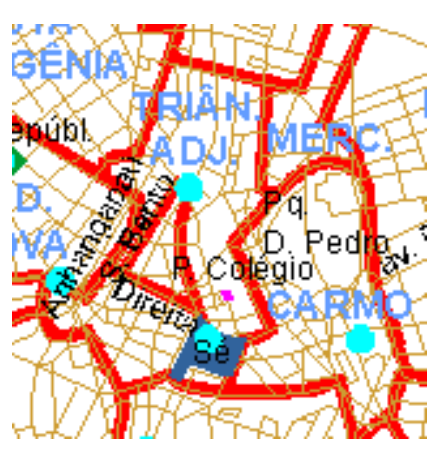

\section{ANTERIOR A 1890}

A evolução dessa área, correspondente ao centro histórico paulistano, se confunde com a própria evolução da cidade, oficialmente fundada em 1554 no Pátio do Colégio. Pouco desenvolvida nos primeiros séculos que se sucederam à sua fundação, a região não apresentava grandes diferenciações de uso, sendo caracterizada, portanto, por um uso misto, onde residências conviviam lado a lado com o comércio, principalmente de gêneros alimentícios. (MÜLLER, N. 1958 p.134 e p.135). Com o desenvolvimento da economia cafeeira, principalmente a partir do segundo quartel do século XIX a área sofreu intensas transformações. As casas de taipa foram substituídas por novas e melhores residências de tijolo e praças, ruas, avenidas e parques foram remodelados. A partir de 1880/1890 o Triângulo consolidou-se como 0 centro comercial da elite, provocando o afastamento das residências para outras áreas (SÃO PAULO, PMSP, SERA 1992 p.41).

\section{0-1921}

Nesse período o Triângulo consolidou sua função comercial/serviços, havendo a expansão desse comércio/serviços para as adjacências do Triângulo (MÜLLER, N. 1958 p.137).

\section{2-1951}

A partir do final dos anos 20 a região começou a sofrer intenso processo de verticalização, prevalecendo sua função comercial e de serviços (MÜLLER, N. 1958 p.150 e p.151)(ROLNIK, R. 1997 p.128)(TARALLI, C. 1993 p.123 e p.189).

\section{2-1971}

Ao longo desse período ocorreu um afastamento maior do uso comercial/serviços de elite, que se deslocou para outros bairros, principalmente no setor sudoeste da cidade e o aumento do uso comercial popular, inicialmente no setor leste da área e posteriormente em toda a região (CORDEIRO, H. 1980 p.59)(VILLAÇA, F. 1998 p.264 e p. 297).

\section{2-1999}

Nos anos 60, principalmente, intensificou-se a popularização do comércio/serviços na área. Nos anos 70 o Metrô provocou profundas transformações na acessibilidade da região. Os calçadões reforçaram o comércio popular (ICI 1992 v.1 p.9)(CORDEIRO, H. 1980 p.100)(PONCIANO, L. 1999 p.118). Há também no Triângulo e Adjacências regiões com concentrações de determinados usos, como máquinas e ferramentas na rua Florêncio de Abreu, brinquedos e armarinhos na rua Vinte e Cinco de Março, Bancos nas rua Boa Vista, escritórios de advocacia na Praça João Mendes. 
Nas últimas décadas, com o agravamento da crise econômica, a área, mais do que outras regiões da cidade, assistiu a um proporcional agravamento de seus problemas sociais, como a violência, o comércio informal, os moradores de rua, a falta de conservação dos edifícios, muitos deles vagos. Contudo, inúmeros projetos, da iniciativa privada e dos poderes públicos estão sendo elaborados para sua revitalização (CORDEIRO, H. 1980 p.19)(ROLNIK, R. 1997 p.91)(ICl 1994 V.3 p.13)(IBGE 2001).

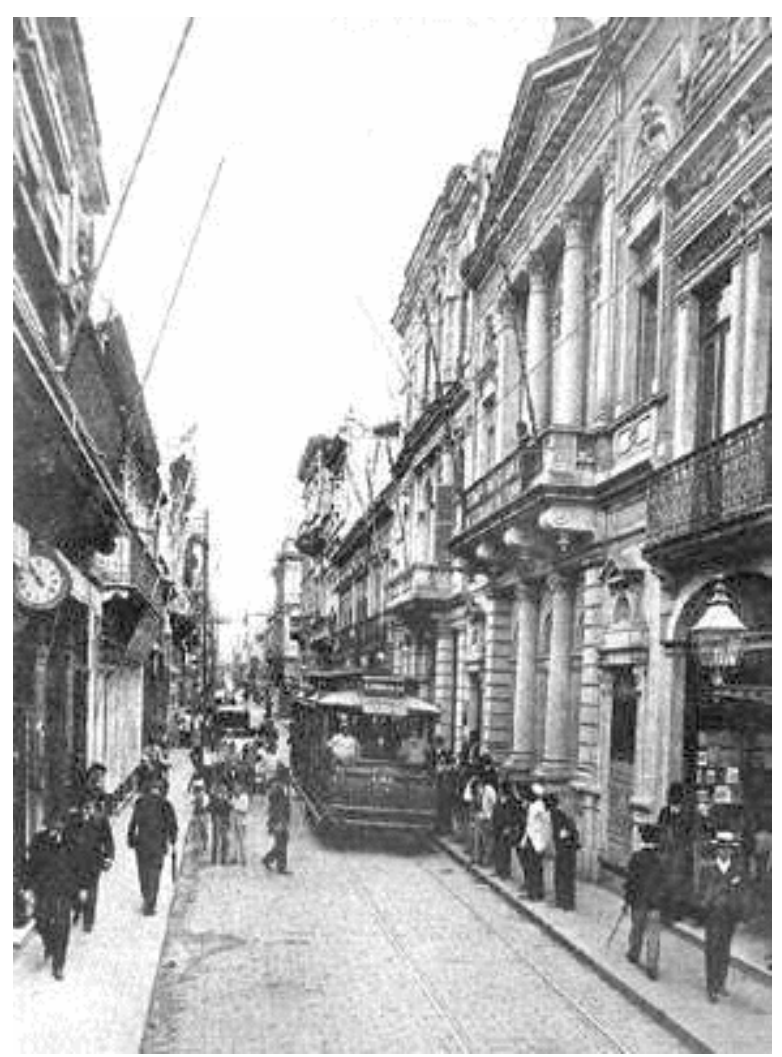

Rua São Bento em 1906. Foto Guilherme Gaensly (ACERVO DO ARQUIVO DO ESTADO, PROIBIDA REPRODUÇÃO)

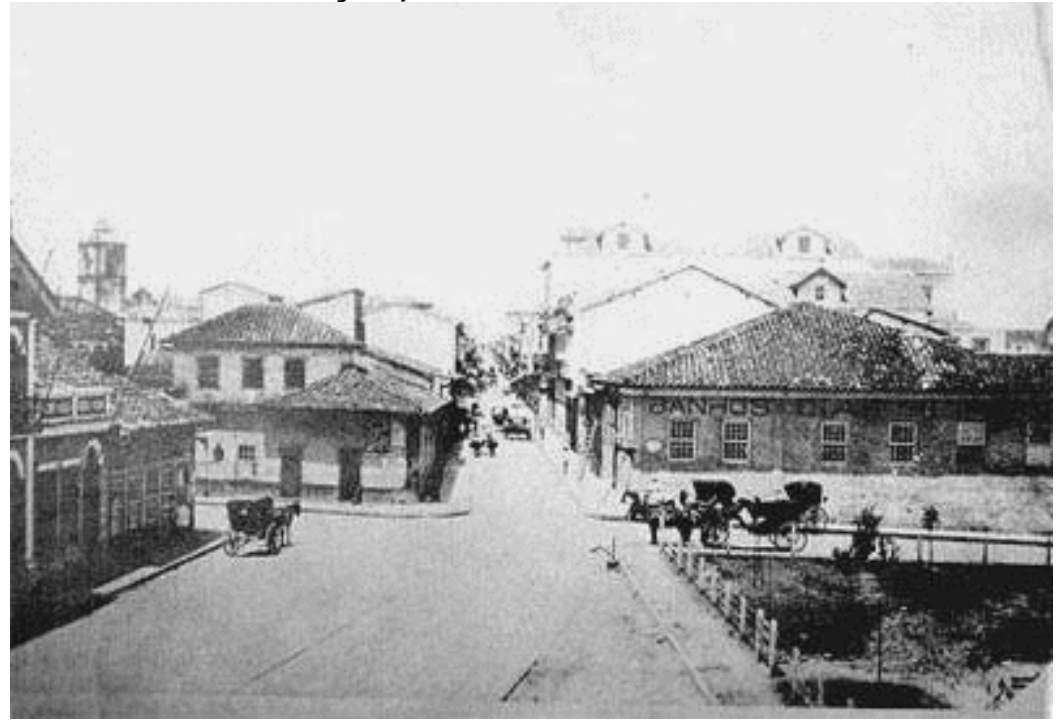

Largo de São Bento em 1887. Foto de Militão (ACERVO DO ARQUIVO DO ESTADO, PROIBIDA REPRODUÇÃO) 


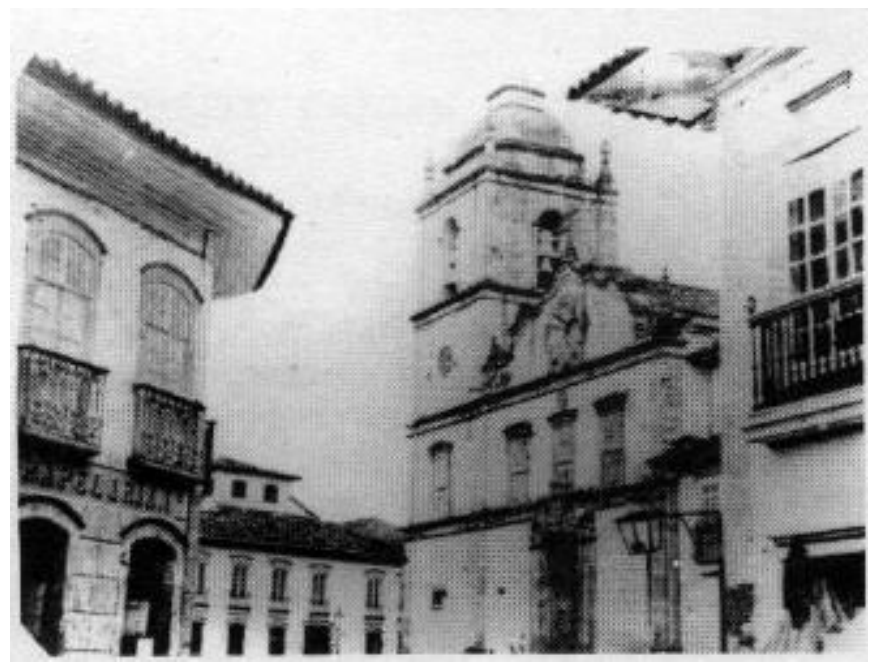

Praça da Sé em 1862 (ACERVO DO ARQUIVO DO ESTADO, PROIBIDA REPRODUÇÃO)

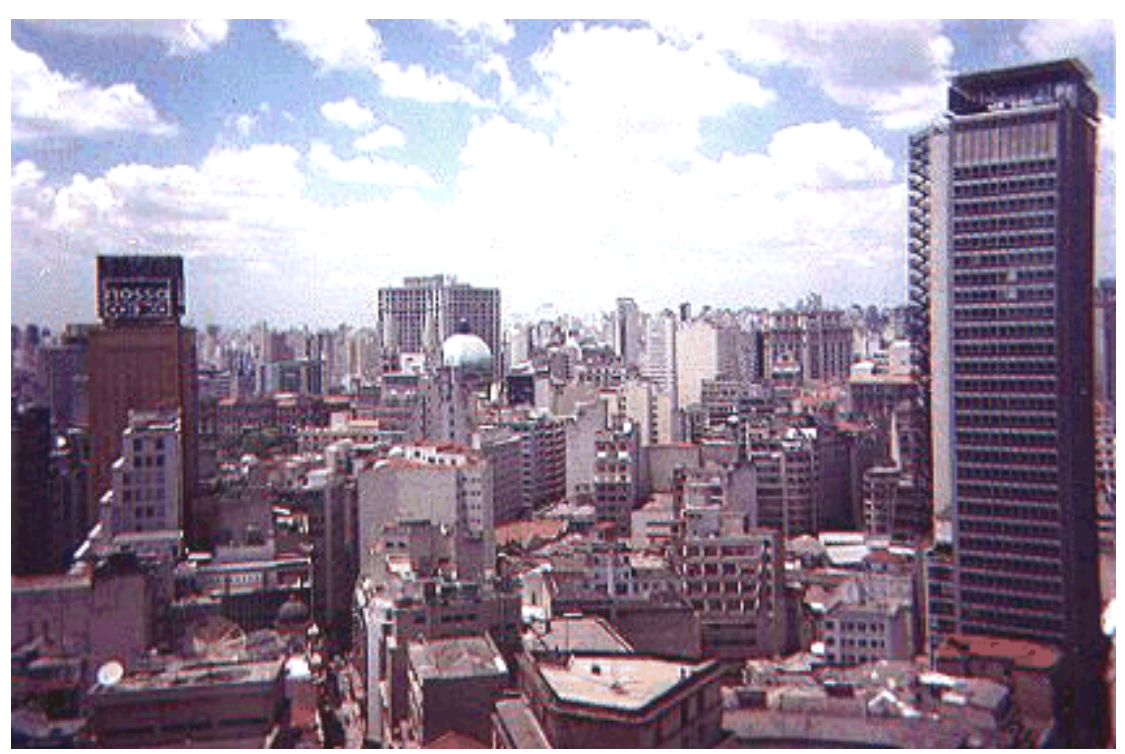

O Triângulo fotografado do Edifício Martinelli na R. São Bento em direção à Praça da Sé. Foto de 2000 
VILA IPOJUCA/CAMPOS DE ESCOLÁSTICA

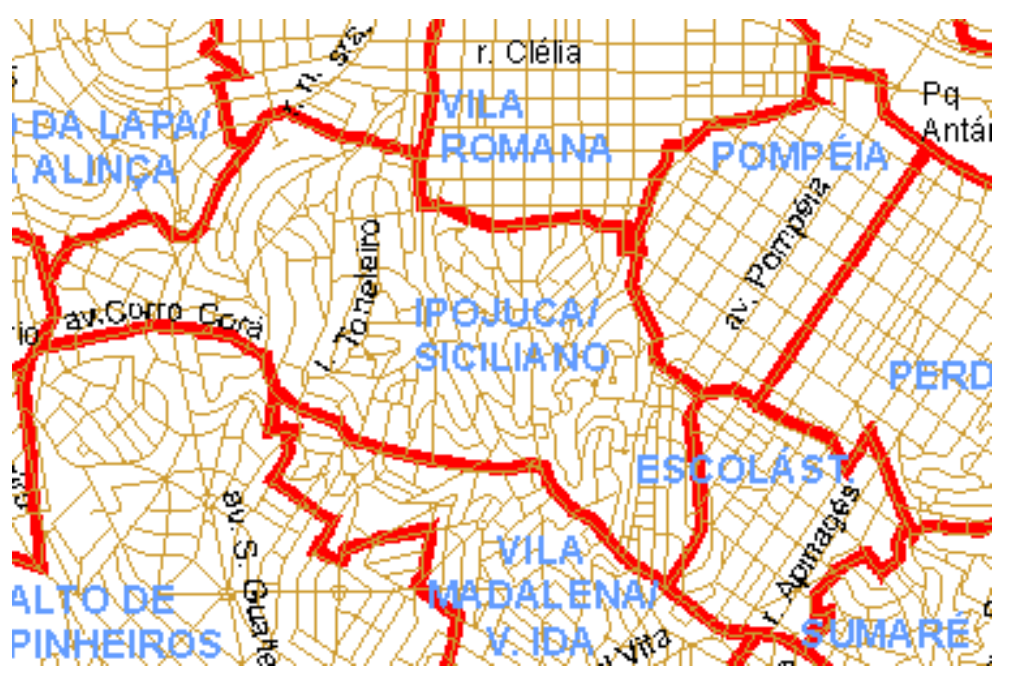

\section{ANTERIOR A 1890}

\section{0-1921}

\section{2-1951}

Essa região começou a ser loteada no início da década de 20 e foi ocupada por uso residencial modesto (SEGATTO, J. 1988 p.21) com alguma classe média em Campos de Escolástica (MENDES, R. 1958 p.343). Mais ocupado nos anos 40 , devido a sua proximidade com o Sumaré é muitas vezes assim denominado (PONCIANO 1999 p.122).

\section{2-1971}

Nos anos 50 começou a sofrer início de verticalização (MENDES, R. 1958 p.345)(CESAD/FAUUSP/PMSP/TPCL 1971).

\section{2-1999}

Nesse período houve aumento do uso residencial vertical e do comércio/serviços, principalmente nas proximidades do Sumaré e das avenidas Cerro Corá e Heitor Penteado (PMSP 2000 V.1 p.29)(PMSP 2000 mapa uso solo 2000). 


\section{VILA LEOPOLDINA / HAMBURGUESA / VILA ANASTÁCIO}

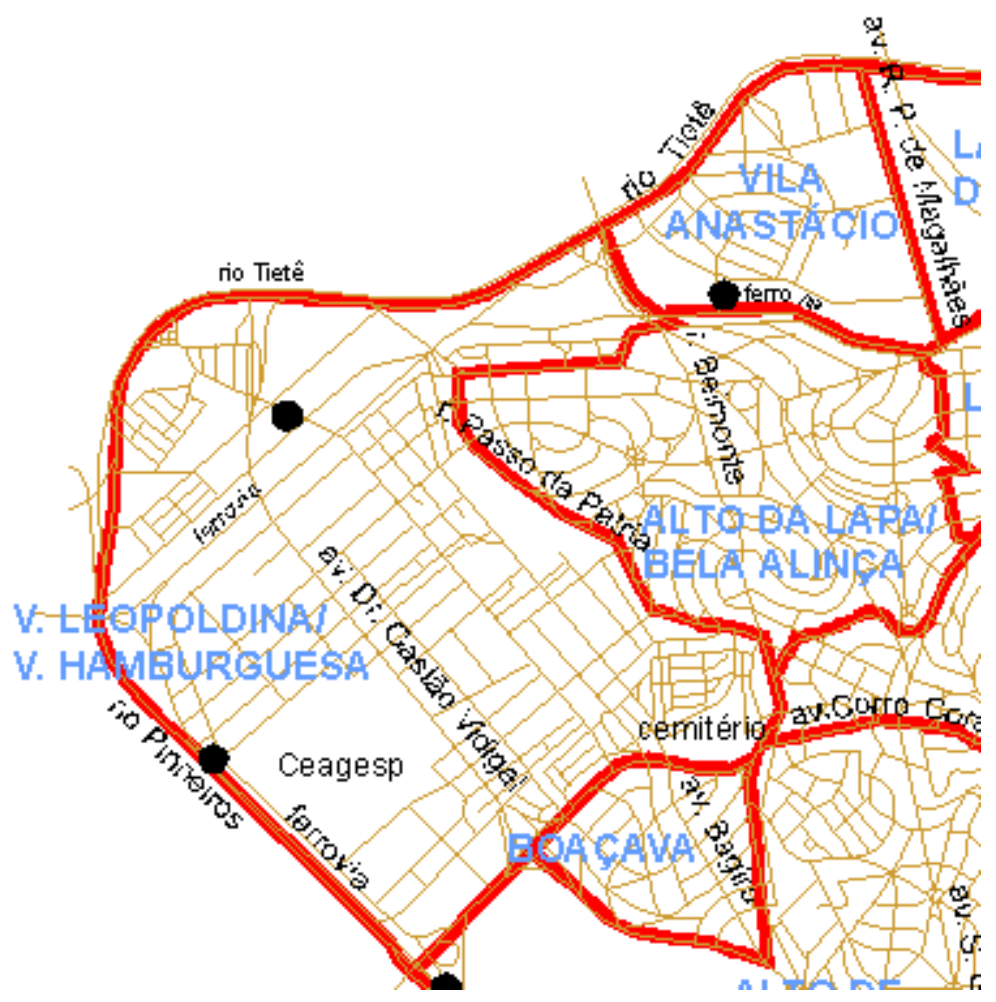

\section{ANTERIOR A 1890}

No final do século XVI havia próximo à confluência dos rios Tietê e Pinheiro o forte do Embuaçava (PONCIANO, L. 1999 p.103)(SANTOS, W. 1980 p.13).

1890-1921

Em 1894 a área era ocupadas por sítios e residências modestas (LOBO JR, M. 1986 p.26)(PONCIANO, L. 1999 p.131). Em 1909 foi feito o loteamento de Vila Anastácio, residencial horizontal operário, ocupado por muitos imigrantes do leste europeu (PONCIANO, L. 1999 p.127) e loteamentos em Vila Leopoldina (PONCIANO, L. 1999 p.131).

\section{2-1951}

Em 1926 algumas áreas ainda estavam sendo loteadas (SEGATTO, J. 1988 p.21).

Após os anos 30 e 40 ocorreu significativo aumento de indústrias (SEGATTO, J. 1988 p.33)(LOBO JR, M. 1986 p.63).

\section{2-1971}

Conservou sua antiga ocupação, residencial modesto e industrial, sendo que 0 uso industrial em Vila Leopoldina teve grande impulso com a construção do centro industrial Mofarrej (PONCIANO, L. 1999 p.131). A construção do Ceasa em 1966 (atual CEAGESP), centro distribuidor de horti-fruti-granjeiros, atraiu novos usos para o bairro (PONCIANO, L. 1999 p.131 e p.132)(SEGATTO, J. 1988 p.43)(ZMITROWICZ, W. 1979 p. 130).

\section{2-1999}

A instalação do novo prédio dos Correios, no início do período, atraiu novos usos de comércio e serviços para a Vila Leopoldina (PITTA, I 19/04/2000 ESP).

Na última década ocorreu um aumento de apartamentos principalmente em 
Vila Hamburguesa, próxima ao Alto da Lapa. Ocorreu também a diminuição do uso industrial e o aumento do comércio/serviços, principalmente em Vila Leopoldina (PMSP 2000 mapa uso do solo 1999)(PONCIANO, L. 1999 p.127).

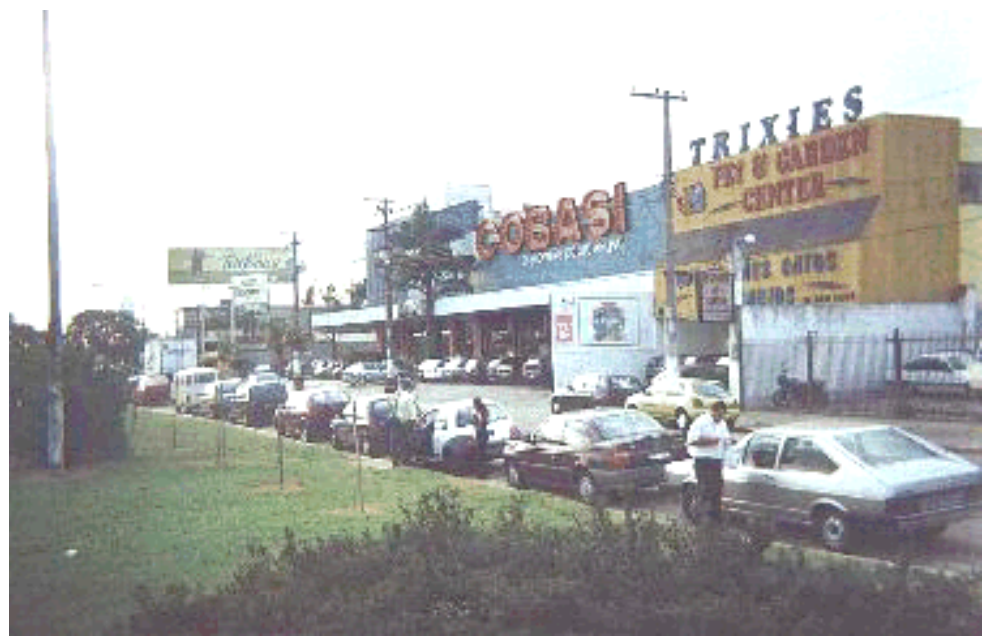

Vila Leopoldina. Foto de 2001 
VILA MADALENA / VILA IDA

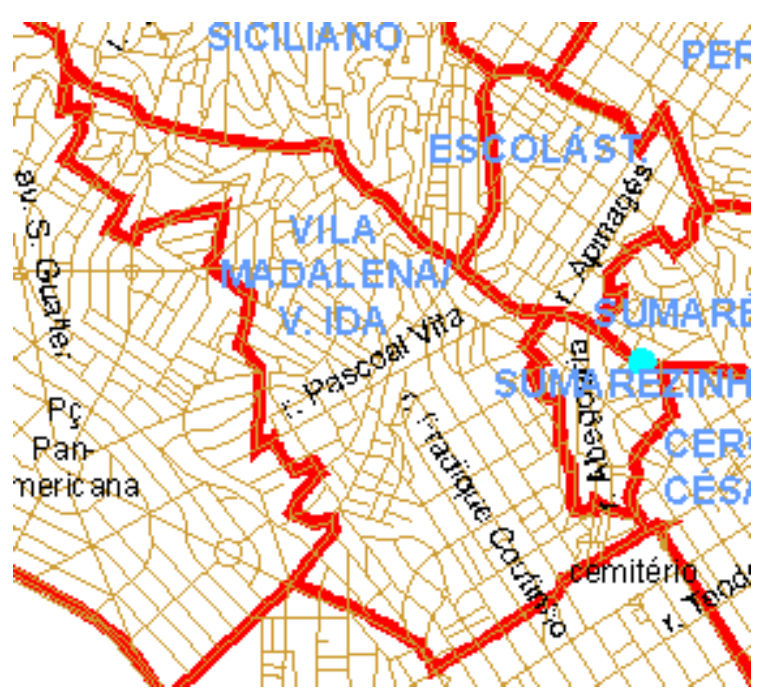

\section{ANTERIOR A 1890}

\section{0-1921}

No início do século XX essa área era povoada por algumas poucas casas de baixa renda (PONCIANO, L. 1999 p.87).

\section{2-1951}

Em 1924, segundo Ponciano havia apenas dez casas de alvenaria e alguns barracos na região, sendo muito difícil o acesso ao bairro, feito somente a pé ou a cavalo (PONCIANO, L. 1999 p.87). Nesse período o bairro começou a receber maior infra-estrutura.

\section{2-1971}

Permaneceu com o uso residencial horizontal de baixa renda (JELIN, D. 1998 p.z-8).

\section{2-1999}

Nesse período o bairro sofreu intensas transformações. Segundo Ponciano, no início da década de 70 o conjunto residencial dos estudantes da Universidade de São Paulo, na Cidade Universitária (fora da área de estudo) foi fechado. Os estudantes então procuraram a Vila Madalena, uma região relativamente próxima da Cidade Universitária, já urbanizada e onde os aluguéis eram de baixo custo. Com a vinda dos estudantes intensificou-se, principalmente a partir dos anos 80 a vida cultural e noturna do bairro. Nesse período também foi intensa a verticalização, com aumento de comércio e serviços (PONCIANO, L. 199 p.88)(JELIN, D. 1998 p.z-8)(CESAD/FAUUSP/PMSP/TPCL 1971)(PMSP 2000 mapa uso solo 1999)(PMSP 2000 v.1 p.29). 


\section{VILA MARIANA, VILA CLEMENTINO}

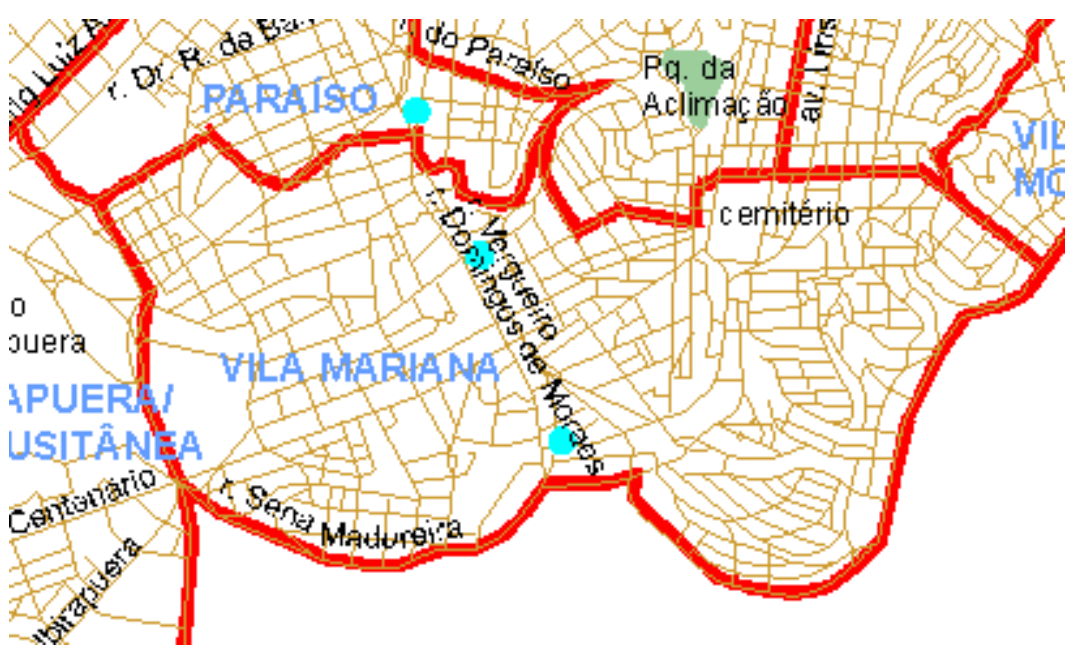

\section{ANTERIOR A 1890}

Por volta de 1770 a região era pouco habitada, também servindo como passagem para as tropas (MASAROLO, p. 1971 p.13). Em $1887 \mathrm{com}$ a instalação do matadouro em Vila Clementino e a estrada de ferro, a região passou a ter maior desenvolvimento,(TORRES, M. 1977 p.82)(MASAROLO, P 1971 p.41)(ZMITROWICZ, W. 1979 p.85), sendo ocupada principalmente por uso residencial horizontal popular e de classe média (TORRES, M. 1977 p.65)(HOMEM, M. 1980 p.24)(MASAROLO, p. 1971 p.109). Por volta de 1888 instalou-se na região uma fábrica de fósforos (MASAROLO, p. 1971 p.48). 1890-1921

No início do século $X X$ o bairro já estava mais ocupado, permanecendo o uso residencial popular e de classe média (VILLAÇA, F. 1998 p.112)(MASAROLO, p. 1971 p.109).

\section{2-1951}

Nas décadas de 30 e 40 ainda estavam sendo feitos novos loteamentos para classe média no bairro (MASAROLO, p. 1971 p.108).

\section{2-1971}

Permaneceu com uso residencial principalmente de classe média, mas já com alguma presença de comércio/serviços (MENDES, R. 1958 p.283)(MÜLLER, N. 1958 p.167).

\section{2-1999}

A partir dos anos 70 passou a sofrer grande verticalização residencial (SOMEKH, N. 1989 p.103)(TARALLI, C. 1993 p.168), para a qual contribuiu o estabelecimento do metrô (PONCIANO, L. 1999 p.59). Atualmente apresenta áreas com forte desenvolvimento de uso residencial vertical e comércio/serviços para classe média e outras área onde ainda há forte presença de uso residencial horizontal de classe média (PMSP 2000 mapa uso solo 1999)(PMSP 2000 v.1 p.29). 


\section{VILA ROMANA}

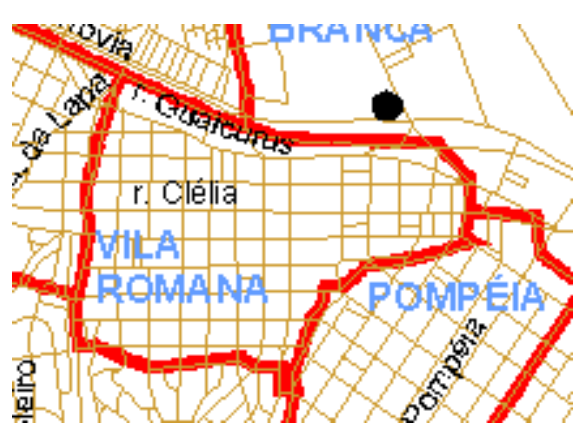

\section{ANTERIOR A 1890}

\section{0-1921}

Na primeira década do século, segundo Villaça, já era um bairro residencial horizontal de classe média (VILLAÇA, F. 1998 p.112).

\section{2-1951}

Continuidade da ocupação.

\section{2-1971}

Nos anos 50 foi descrito por Mendes como um bairro residencial de operários e classe média, com algumas indústrias (MENDES, R. 1958 p.36). Em 1968 mapa de uso do solo do Plano Urbanístico Básico apontava a expansão do comércio da Lapa sobre a Vila Romana (SÃO PAULO (PMSP) 1969 - mapa uso do solo 1968). Dados do TPCL 1971 também apontaram que nessa data já havia forte presença de comércio/serviços no bairro, principalmente nas proximidades da Lapa (CESAD/FAUUSP/TPCL 1971).

\section{2-1999}

A partir da década de 70 o bairro sofreu forte verticalização, além da presença de comércio/serviços (TARALLI, C. 1993 p.168)(PMSP 2000 mapa uso solo 1999)(PMSP 2000 v. 1 p.29). 
Os mapas que se seguem nos mostram o uso do solo na área de estudo em cortes temporais: 1890, 1922, 1952, 1972 e 1999. 


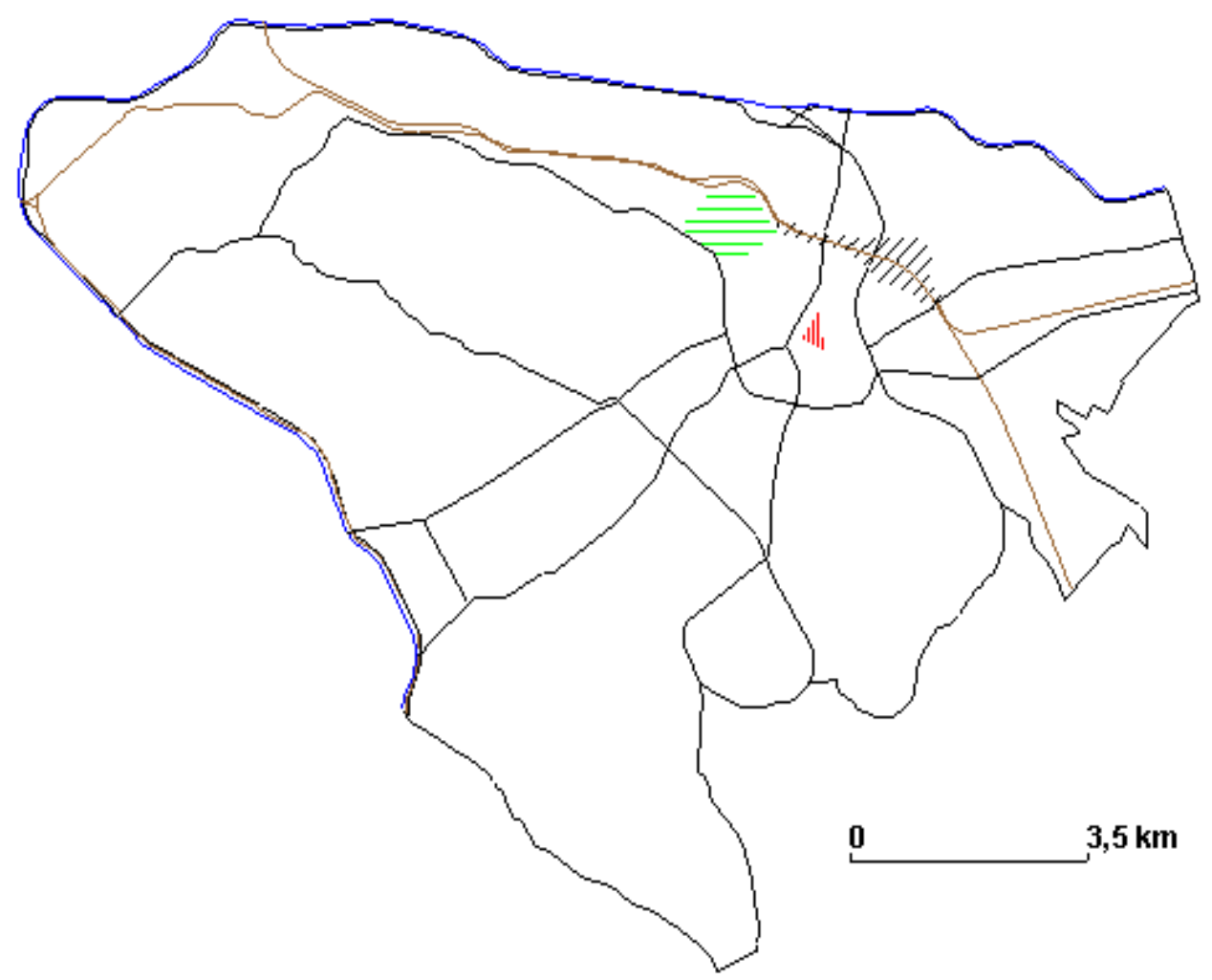

USO DO SOLO 1890

$R E=$ RESIDENCIAL DE ELITE

$A C=$ APTO E COM/SERV

RAC $=$ RESIDENCIAL COM APTO E COM/SERV

$M I=$ MISTO INDUSTRIAL: IND OU RES+IND COM PRESENÇA DE APTOS E/OU COM/SERV

एणl CS= COMÉRCIO E SERVIÇOS

שI:A IR= INDÚSTRIA OU INDÚSTRIA+RESIDENCIAL MODESTO

RESIDENCIAL MODESTO/CLASSE MÉDIA OU ÁREA NÃO URBANIZADA

PERÍMETROS APROXIMDADOS. NÃO INCLUI CORREDORES COMERCIAIS SECUNDÁRIOS. USOS PREDOMINANTES, NÃO EXIBE PEQUENAS ÁREAS. ÁREAS DE LAZER INCLUÍDAS EM SEUS USOS LINDEIROS 


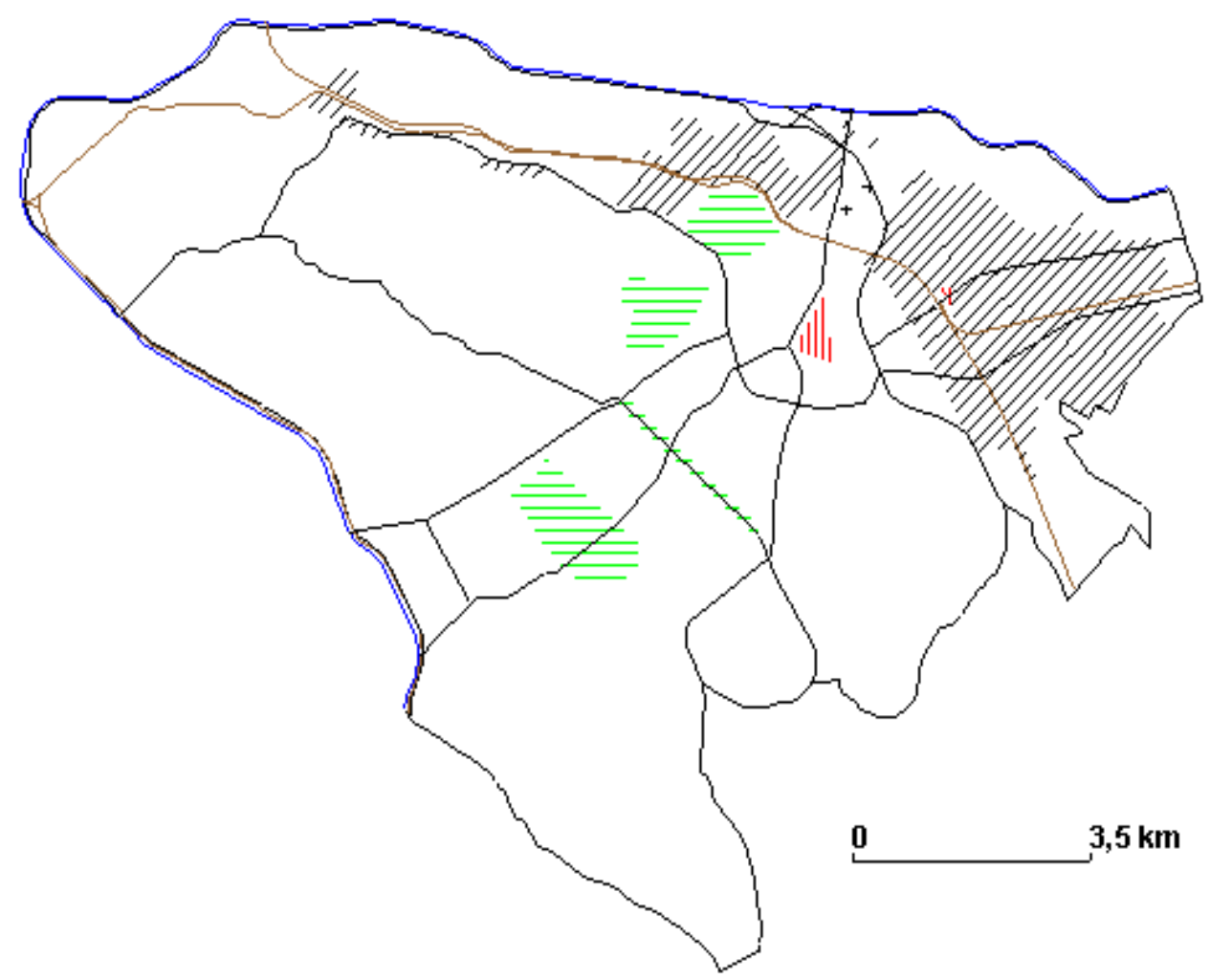

USO DO SOLO 1922

$R E=$ RESIDENCIAL DE ELITE

$A C=$ APTO E COM/SERV

RAC $=$ RESIDENCIAL COM APTO E COM/SERV

$M I=$ MISTO INDUSTRIAL: IND OU RES+IND COM PRESENÇA DE APTOS E/OU COM/SERV

एणl CS= COMÉRCIO E SERVIÇOS

שI:A IR= INDÚSTRIA OU INDÚSTRIA+RESIDENCIAL MODESTO

RESIDENCIAL MODESTO/CLASSE MÉDIA OU ÁREA NÃO URBANIZADA

PERÍMETROS APROXIMADOS. NÃO INCLUI CORREDORES COMERCIAIS SECUNDÁRIOS. USOS PREDOMINANTES, NÃO EXIBE PEQUENAS ÁREAS. ÁREAS DE LAZER INCLUÍDAS EM SEUS USOS LINDEIROS 


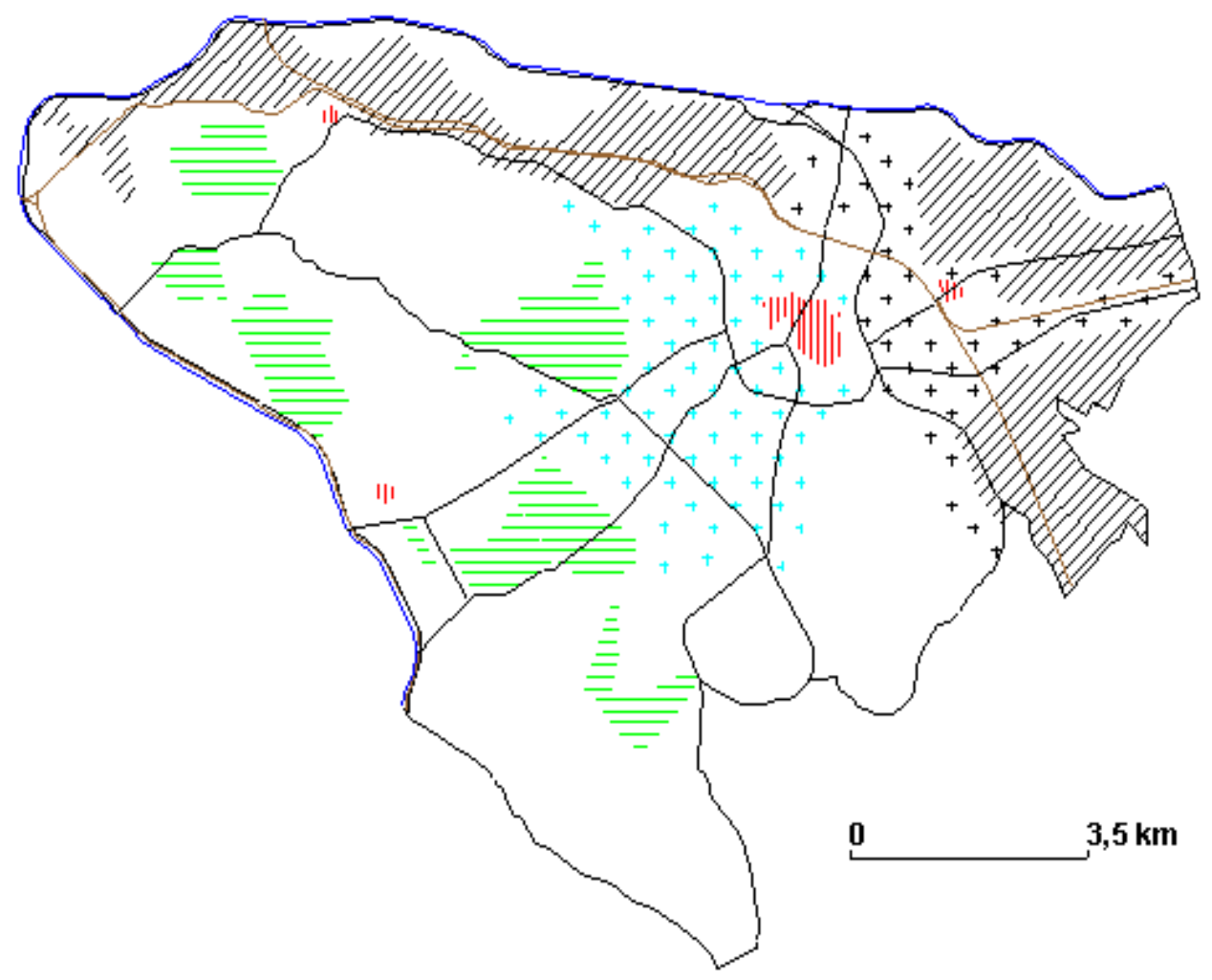

\section{USO DO SOLO 1952}

$R E=$ RESIDENCIAL DE ELITE

$A C=$ APTO E COM/SERV

RAC $=$ RESIDENCIAL COM APTO E COM/SERV

MI= MISTO INDUSTRIAL: IND OU RES+IND COM PRESENÇA DE APTOS E/OU COM/SERV

ㅁ] CS= COMÉRCIO E SERVIÇOS

WII IR= INDÚSTRIA OU INDÚSTRIA+RESIDENCIAL MODESTO

RESIDENCIAL MODESTO/CLASSE MÉDIA OU ÁREA NÃO URBANIZADA

PERÍMETROS APROXIMDADOS. NÃO INCLUI CORREDORES COMERCIAIS SECUNDÁRIOS. USOS PREDOMINANTES, NÃO EXIBE PEQUENAS ÁREAS. ÁREAS DE LAZER INCLUÍDAS EM SEUS USOS LINDEIROS 


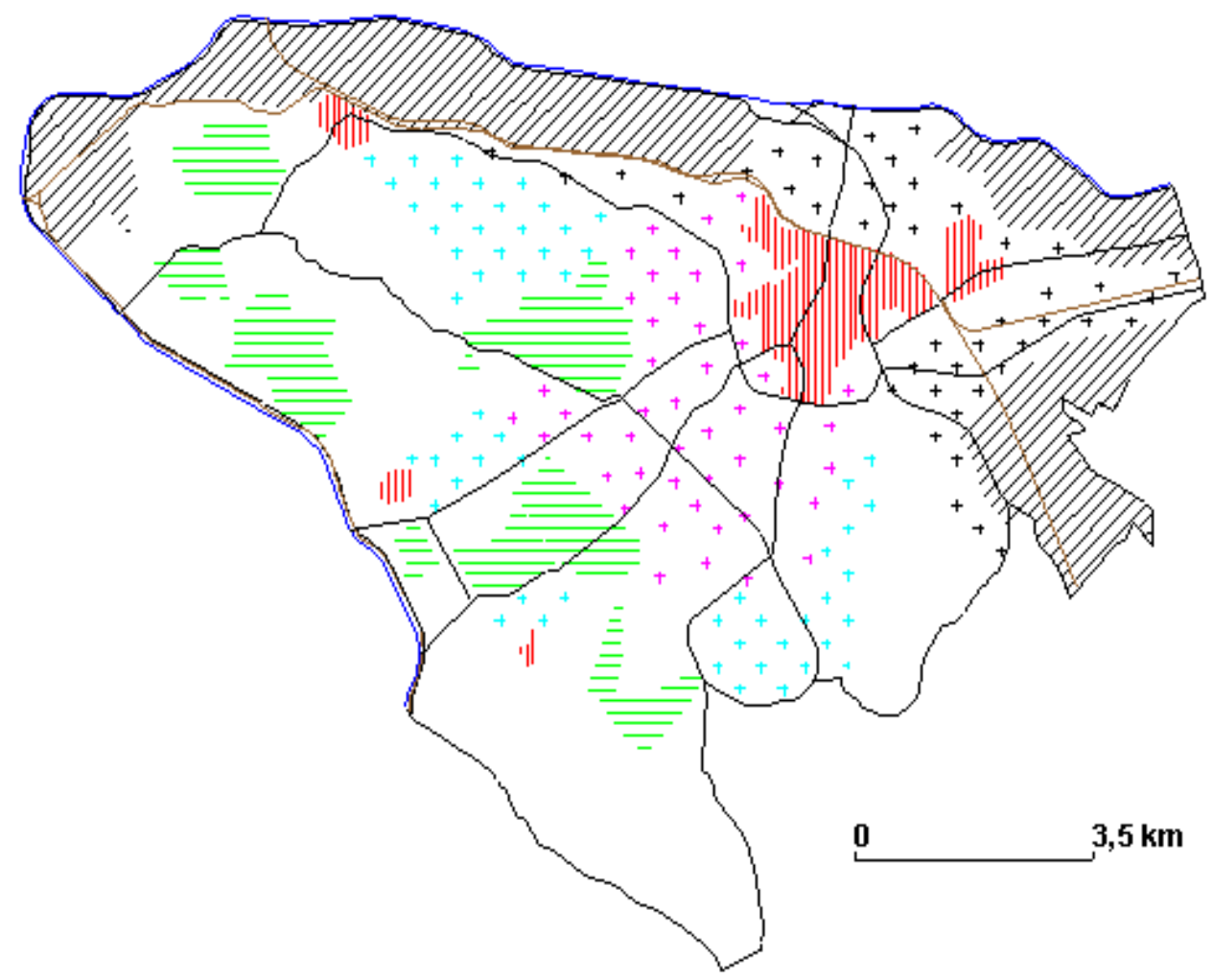

\section{USO DO SOLO 1972}

$R E=$ RESIDENCIAL DE ELITE

$A C=$ APTO E COM/SERV

RAC $=$ RESIDENCIAL COM APTO E COM/SERV

$M I=$ MISTO INDUSTRIAL: IND OU RES+IND COM PRESENÇA DE APTOS E/OU COM/SERV

ㅁ] CS= COMÉRCIO E SERVIÇOS

WII IR= INDÚSTRIA OU INDÚSTRIA+RESIDENCIAL MODESTO

RESIDENCIAL MODESTO/CLASSE MÉDIA OU ÁREA NÃO URBANIZADA

PERÍMETROS APROXIMDADOS. NÃO INCLUI CORREDORES COMERCIAIS SECUNDÁRIOS. USOS PREDOMINANTES, NÃO EXIBE PEQUENAS ÁREAS. ÁREAS DE LAZER INCLUÍDAS EM SEUS USOS LINDEIROS 


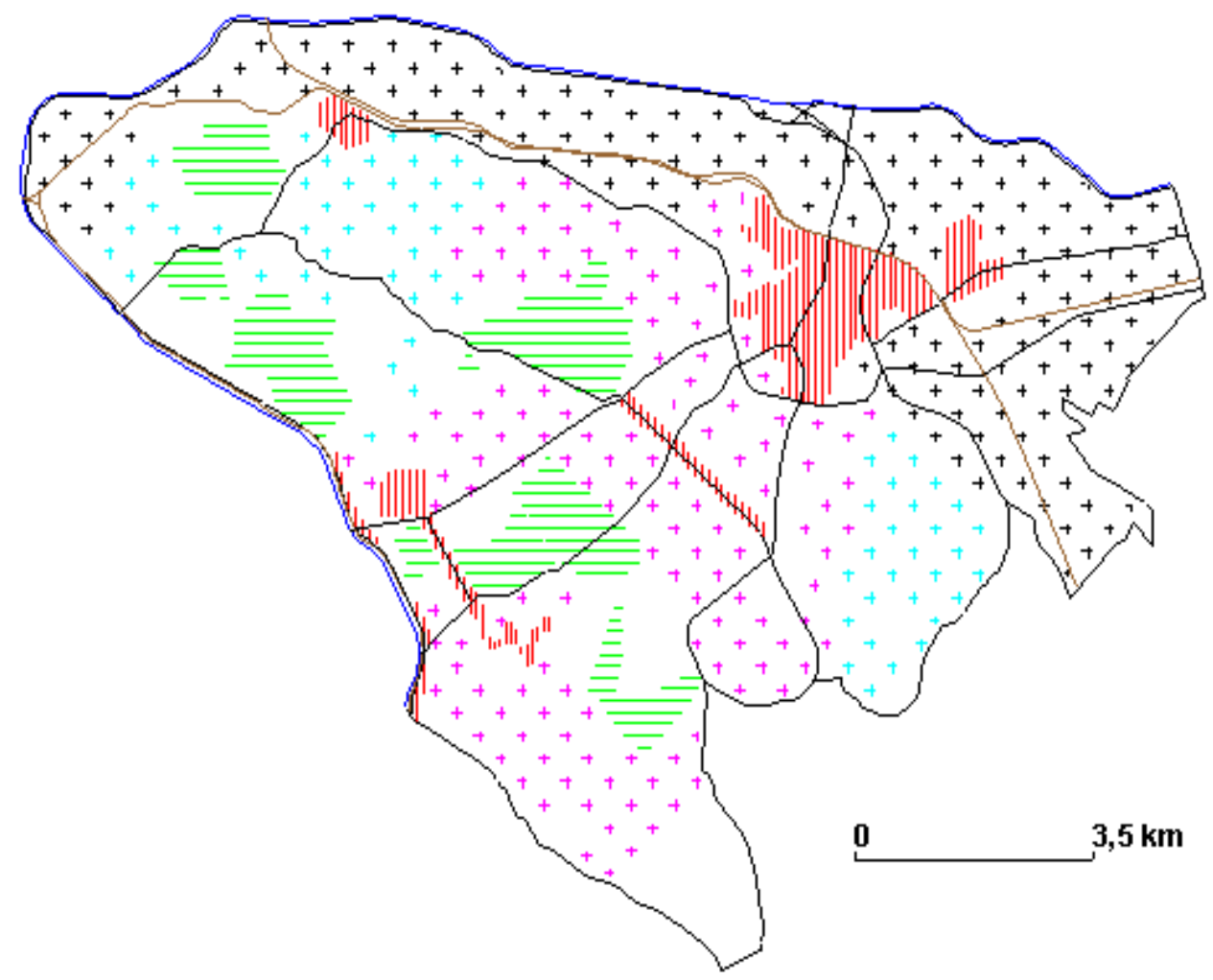

USO DO SOLO 1999

RE $=$ RESIDENCIAL DE ELITE

$A C=$ APTO E COM/SERV

RAC $=$ RESIDENCIAL COM APTO E COM/SERV

$\mathrm{MI}=$ MISTO INDUSTRIAL: IND OU RES+IND COM PRESENÇA DE APTOS E/OU COM/SERV

ㅁ] CS= COMÉRCIO E SERVIÇOS

WII IR= INDÚSTRIA OU INDÚSTRIA+RESIDENCIAL MODESTO

RESIDENCIAL MODESTO/CLASSE MÉDIA OU ÁREA NÃO URBANIZADA

PERÍMETROS APROXIMDADOS. NÃO INCLUI CORREDORES COMERCIAIS SECUNDÁRIOS. USOS PREDOMINANTES, NÃO EXIBE PEQUENAS ÁREAS. ÁREAS DE LAZER INCLUÍDAS EM SEUS USOS LINDEIROS 


\section{2 - PADRÕES DAS TRANSFORMAÇÕES}

Como vimos nos capítulos anteriores, o uso do solo em São Paulo começou a apresentar uma complexidade maior a partir do desenvolvimento da economia cafeeira. Isso ocorreu através de dois fenômenos concomitantes, a instalação de novos usos através da rápida expansão da área urbanizada e a transformação de uso das áreas já consolidadas, o objeto de estudo desta dissertação.

Ao analisarmos o conjunto de mapas síntese dos dados é possível observar a existência de alguns padrões das transformações.

No período entre as décadas de 1860 e 1890 a principal transformação no uso do solo ocorreu na região do Triângulo que passou de um uso do solo misto, fortemente ligado às atividades rurais, com muitas residências, comércio de

gêneros alimentícios e pequenas fábricas artesanais para um uso comercial. A instalação da ferrovia também trouxe novos usos para áreas residenciais já urbanizadas próximas.

Entre 1890 e 1922 ocorreram outras substituições de usos, principalmente do uso residencial por comércio, como a expansão do comércio do Triângulo sobre as áreas adjacentes e no Brás surgiu o primeiro subcentro comercial popular.

No período entre 1922 e 1952 as substituições de usos foram intensas. O uso comercial do Triângulo e adjacências expandiu-se ainda mais atingindo principalmente a região da Cidade Nova. Toda essa área, do centro tradicional, também começou a se verticalizar, com edifícios destinados principalmente ao uso comercial e de serviços. Nesse período novos 
subcentros populares também se consolidaram, adquirindo maior importância, como a Lapa e Pinheiros. No Bom Retiro intensificou-se a ocupação com pequenas indústrias ligadas ao comércio. Antigas áreas residenciais começaram a se transformar em áreas constituídas pelo uso residencial horizontal, apartamentos e uso comercial/serviços. Isto ocorreu tanto em áreas residenciais horizontais de elite como Campos Elíseos e Higienópolis, como em outras áreas residenciais próximas ao centro tradicional, como na Consolação, Bela Vista, Liberdade, Santa Ifigênia, Barra Funda, Santa Cecília, Vila Buarque e atingindo até mesmo algumas áreas de Perdizes, Cerqueira César, Paraíso e Jardim Paulista.

Entre 1952 e 1972 houve expansão do uso comercial do centro histórico sobre os bairros vizinhos. Os subcentros de comércio e serviços populares como Brás, Lapa e Pinheiros também cresceram. O uso comércio e serviços de elite começou a abandonar o centro tradicional deslocando-se para a região da avenida Paulista. Houve também o crescimento de comércio/serviços e, sobretudo, de apartamentos em bairros como Cerqueira César, Jardim Paulista, Vila Mariana.

A partir dos anos 70 não houve grande expansão do uso comércio/serviços no centro histórico. Entretanto, o uso comércio e serviços, principalmente de elite, consolidou-se e expandiu-se pelo Jardim Paulista, Jardim Paulistano, Itaim (sobrepondo-se ao comércio popular) e Moema. É importante observar que nesse período tanto o uso comércio/serviços como o residencial vertical sofreram grande crescimento em toda a área de estudo, transformando áreas residenciais horizontais em áreas com uso residencial horizontal, comércio e serviços e residencial vertical. Nesse estágio encontram-se bairros como 
Aclimação, Pompéia, Vila Ipojuca, Campos de Escolástica, parte de Vila Mariana, Cambuci. Outras áreas já apresentam uso predominantemente residencial vertical e comércio/serviços como Itaim, Moema/Indianópolis. Houve também diminuição do uso industrial. Há, portanto, alguns padrões nas transformações:

1. De uso misto com grande número de residências para comercial como aconteceu no Triângulo ainda no século XIX.

2. De uso residencial horizontal ou uso residencial horizontal e industrial para comercial.

3. De uso residencial horizontal para uso residencial horizontal com comércio/serviços e aptos, que pode ou não evoluir para uso com predomínio apenas de comércio e aptos, com variações na intensidade dos dois usos e na velocidade da transformação.

4. De uso industrial ou industrial/residencial operário para uso misto industrial, principalmente através do aumento do comércio/serviços e uso residencial vertical, com diminuição do uso industrial.

5. Também podemos observar que há uma razoável preservação de alguns bairros residenciais horizontais de elite e classe média alta em relação às transformações intensas ocorridas em seu entorno.

Os mapas que se seguem nos mostram as principais transformações segundo os períodos: 1860-1890, 1890-1922, 1922-1952, 1952-1972, 1972-1999. O último mapa faz uma síntese das transformações em todo o período, ou seja, de 1860 a 1999. 


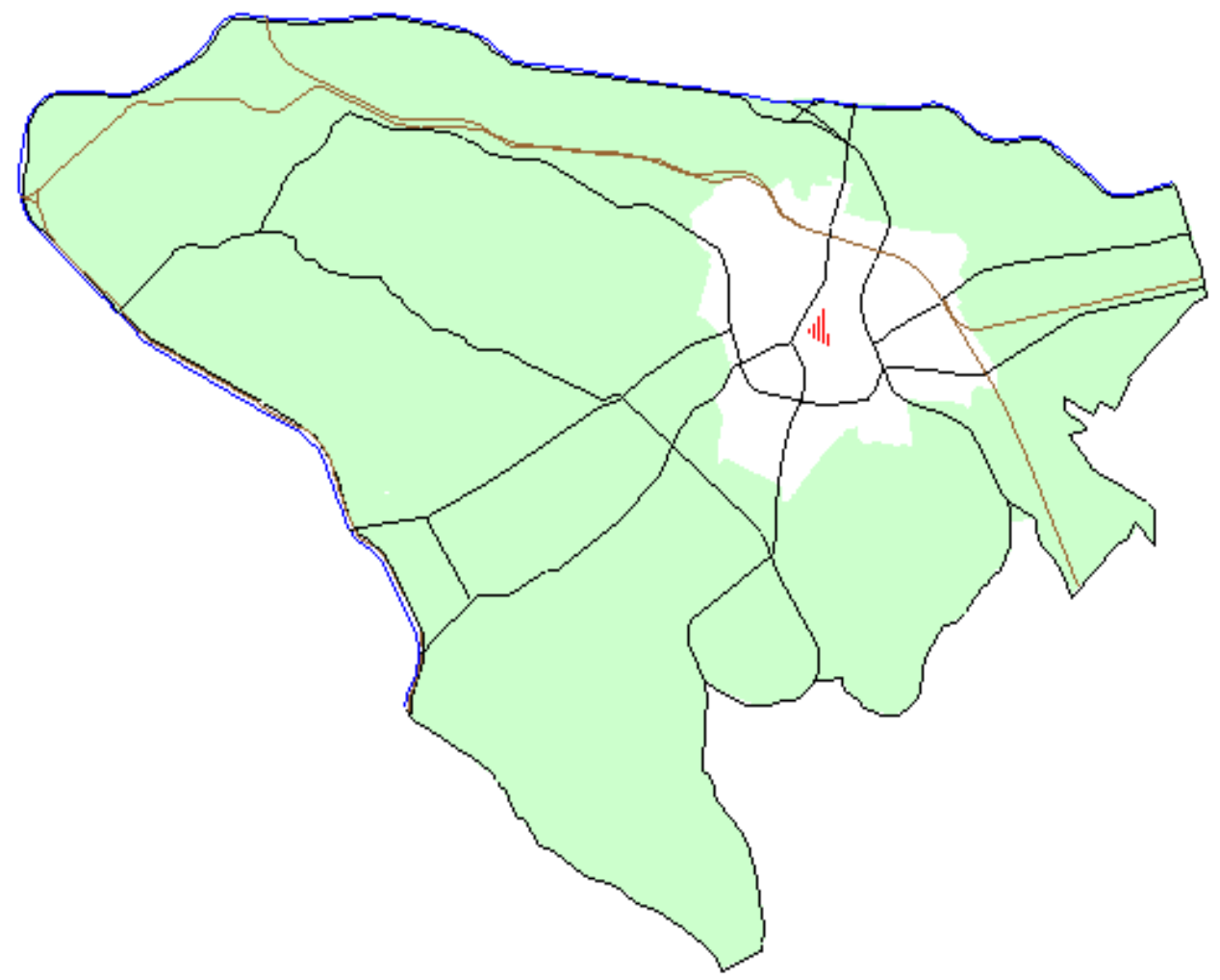

\section{TRANSFORMAÇÕES 1860-1890}

(I) III) MR para CS

R ou IR para CS

$R$ para RAC

RE para RAC

R ou RAC para AC

盂而 RE para RAC para AC

ㅁ. $\mathrm{d}$ RE para RAC para CS

미 R para RAC para CS

IR para MI

ÁREA NÃO URBANIZADA EM 1890

*PARA MAIORES DETALHES CONSULTAR TEXTO DA DISSERTAÇÃO. INCLUI APENAS TRANSFORMAÇÕES NO TIPO DE USO E NÃO EM QUANTIDADE. PERÍMETROS APROXIMADOS, NÃO INCLUI CORREDORES COMERCIAIS SECUNDÁRIOS. USOS PREDOMINANTES, NÃO EXIBE PEQUENAS ÁREAS. ÁREAS DE LAZER INCLUÍDAS EM SEUS USOS LINDEIROS

MR= USO MISTO RESIDENCIAL/COMERCIAL LIGADO ÀS ATIVIDADES RURAIS

RE $=$ RESIDENCIAL HORIZONTAL DE ELITE

AC= APTO E COMÉRCIO/SERVIÇOS

RAC= RESIDENCIAL HORIZONTAL COM APTOS E COMÉRCIO/SERVIÇOS

MI= MISTO INDUSTRIAL: IND OU RES+IND COM PRESENÇA DE APTOS E/OU COM/SERV

CS= COMÉRCIO/SERVIÇOS (CENTRO E SUBCENTRO)

IR= INDÚSTRIA OU INDÚSTRIA+RESIDENCIAL MODESTO

R= RESIDENCIAL MODESTO/CLASSE MÉDIA 


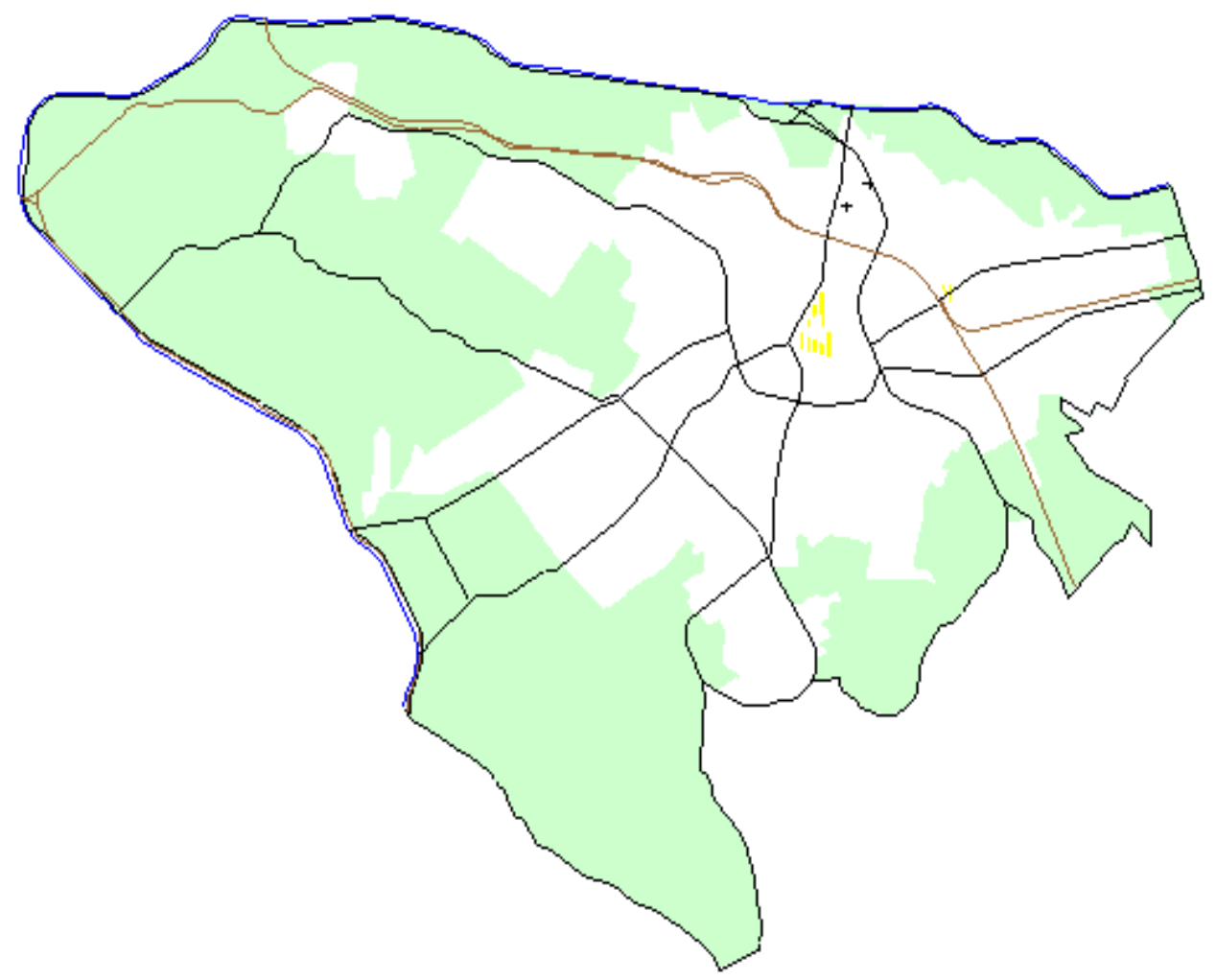

\section{TRANSFORMAÇÕES 1890-1922}

盂耑 MR para CS

$R$ ou IR para CS

$R$ para RAC

RE para RAC

R ou RAC para AC

盂而 RE para RAC para AC

血 RE para RAC para CS

미 R para RAC para CS

IR para MI

ÁREA NÃO URBANIZADA EM 1922

*PARA MAIORES DETALHES CONSULTAR TEXTO DA DISSERTAÇÃO. INCLUI APENAS TRANSFORMAÇÕES NO TIPO DE USO E NÃO EM QUANTIDADE. PERÍMETROS APROXIMADOS, NÃO INCLUI CORREDORES COMERCIAIS SECUNDÁRIOS. USOS PREDOMINANTES, NÃO EXIBE PEQUENAS ÁREAS. ÁREAS DE LAZER INCLUÍDAS EM SEUS USOS LINDEIROS

MR= USO MISTO RESIDENCIAL/COMERCIAL LIGADO ÀS ATIVIDADES RURAIS

$R E=$ RESIDENCIAL HORIZONTAL DE ELITE

AC= APTO E COMÉRCIO/SERVIÇOS

RAC $=$ RESIDENCIAL HORIZONTAL COM APTOS E COMÉRCIO/SERVIÇOS

MI= MISTO INDUSTRIAL: IND OU RES+IND COM PRESENÇA DE APTOS E/OU COM/SERV

CS= COMÉRCIO/SERVIÇOS (CENTRO E SUBCENTRO)

IR= INDÚSTRIA OU INDÚSTRIA+RESIDENCIAL MODESTO

R= RESIDENCIAL MODESTO/CLASSE MÉDIA 


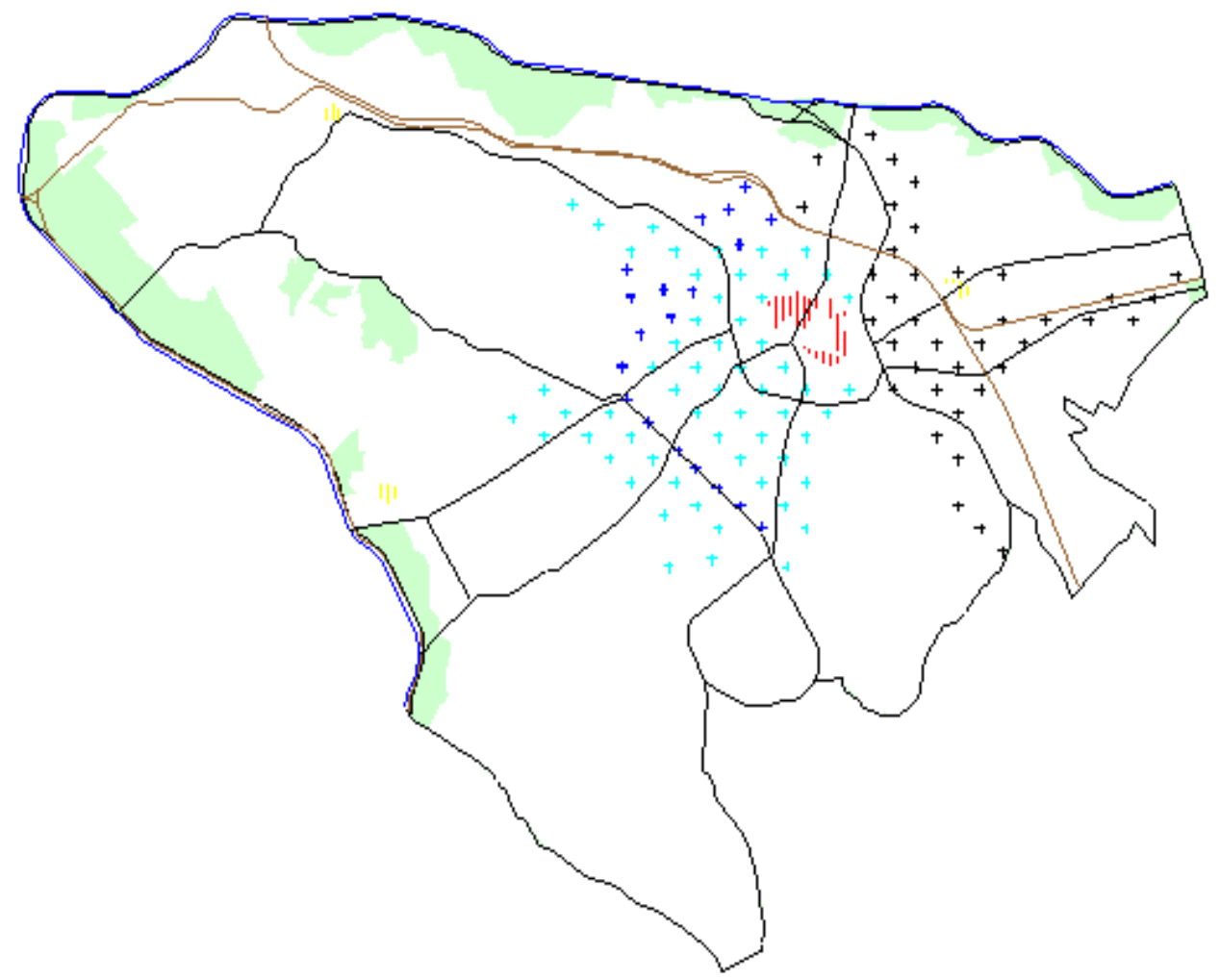

\section{TRANSFORMAÇÕES 1922-1952}

盂耑 MR para CS

$R$ ou IR para CS

$R$ para RAC

RE para RAC

R ou RAC para AC

盂而 RE para RAC para AC

ㅁ. $\mathrm{m}$ RE para RAC para CS

미 R para RAC para CS

H. IR para MI

ÁREA NÃO URBANIZADA EM 1952

*PARA MAIORES DETALHES CONSULTAR TEXTO DA DISSERTAÇÃO. INCLUI APENAS TRANSFORMAÇÕES NO TIPO DE USO E NÃO EM QUANTIDADE. PERÍMETROS APROXIMADOS, NÃO INCLUI CORREDORES COMERCIAIS SECUNDÁRIOS. USOS PREDOMINANTES, NÃO EXIBE PEQUENAS ÁREAS. ÁREAS DE LAZER INCLUÍDAS EM SEUS USOS LINDEIROS

MR= USO MISTO RESIDENCIAL/COMERCIAL LIGADO ÀS ATIVIDADES RURAIS

RE $=$ RESIDENCIAL HORIZONTAL DE ELITE

AC= APTO E COMÉRCIO/SERVIÇOS

RAC $=$ RESIDENCIAL HORIZONTAL COM APTOS E COMÉRCIO/SERVIÇOS

MI= MISTO INDUSTRIAL: IND OU RES+IND COM PRESENÇA DE APTOS E/OU COM/SERV

CS= COMÉRCIO/SERVIÇOS (CENTRO E SUBCENTRO)

IR= INDÚSTRIA OU INDÚSTRIA+RESIDENCIAL MODESTO

R= RESIDENCIAL MODESTO/CLASSE MÉDIA 


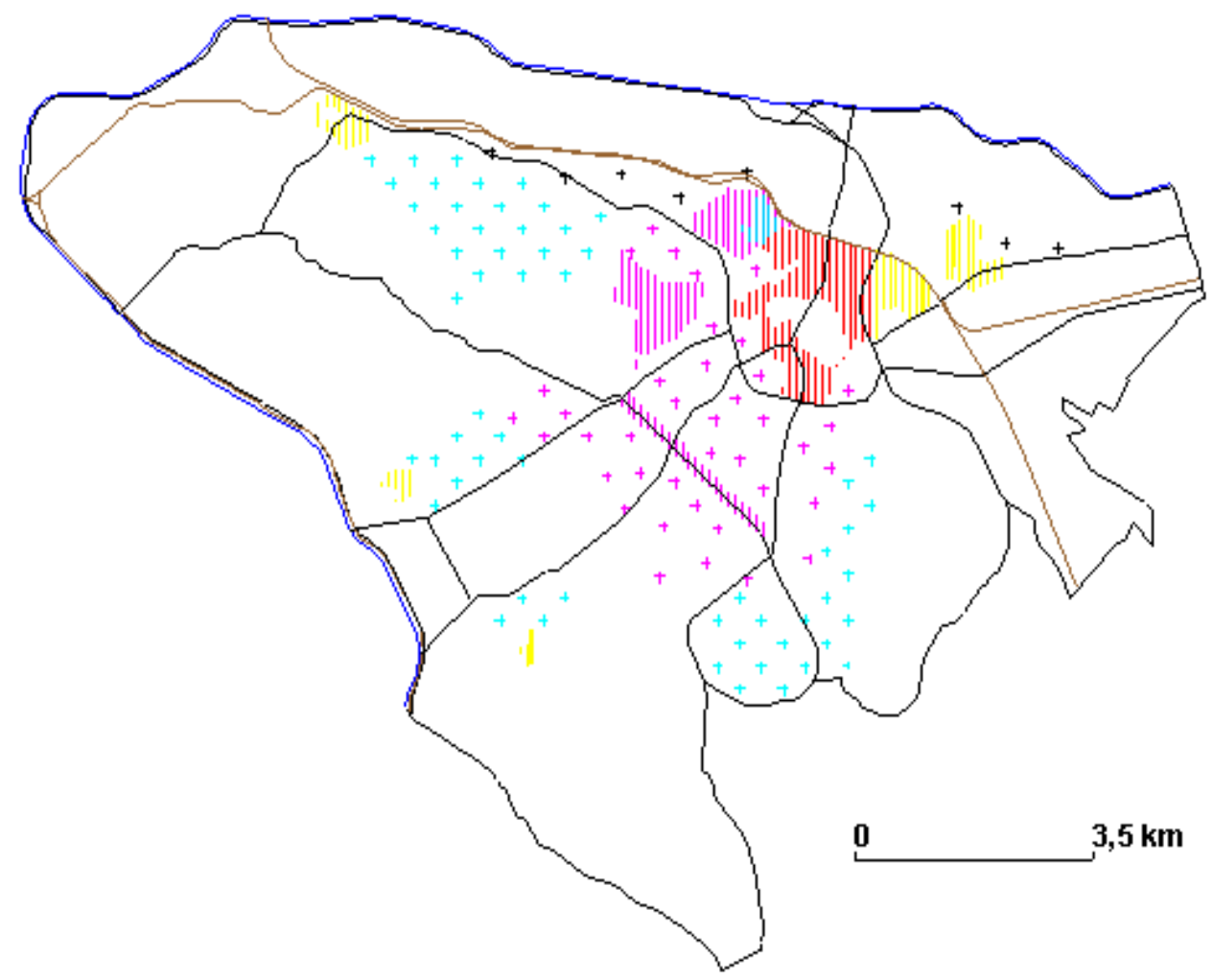

\section{TRANSFORMAÇÕES 1952-1972}

盂耑 MR para CS

R ou IR para CS

$R$ para RAC

RE para RAC

R ou RAC para AC

盂而 RE para RAC para AC

血 RE para RAC para CS

미 R para RAC para CS

IR para MI

ÁREA NÃO URBANIZADA EM 1972

*PARA MAIORES DETALHES CONSULTAR TEXTO DA DISSERTAÇÃO. INCLUI APENAS TRANSFORMAÇÕES NO TIPO DE USO E NÃO EM QUANTIDADE. PERÍMETROS APROXIMADOS, NÃO INCLUI CORREDORES COMERCIAIS SECUNDÁRIOS. USOS PREDOMINANTES, NÃO EXIBE PEQUENAS ÁREAS. ÁREAS DE LAZER INCLUÍDAS EM SEUS USOS LINDEIROS

MR= USO MISTO RESIDENCIAL/COMERCIAL LIGADO ÀS ATIVIDADES RURAIS

$R E=$ RESIDENCIAL HORIZONTAL DE ELITE

AC= APTO E COMÉRCIO/SERVIÇOS

RAC $=$ RESIDENCIAL HORIZONTAL COM APTOS E COMÉRCIO/SERVIÇOS

Ml= MISTO INDUSTRIAL: IND OU RES+IND COM PRESENÇA DE APTOS E/OU COM/SERV

CS= COMÉRCIO/SERVIÇOS (CENTRO E SUBCENTRO)

IR= INDÚSTRIA OU INDÚSTRIA+RESIDENCIAL MODESTO

R= RESIDENCIAL MODESTO/CLASSE MÉDIA 


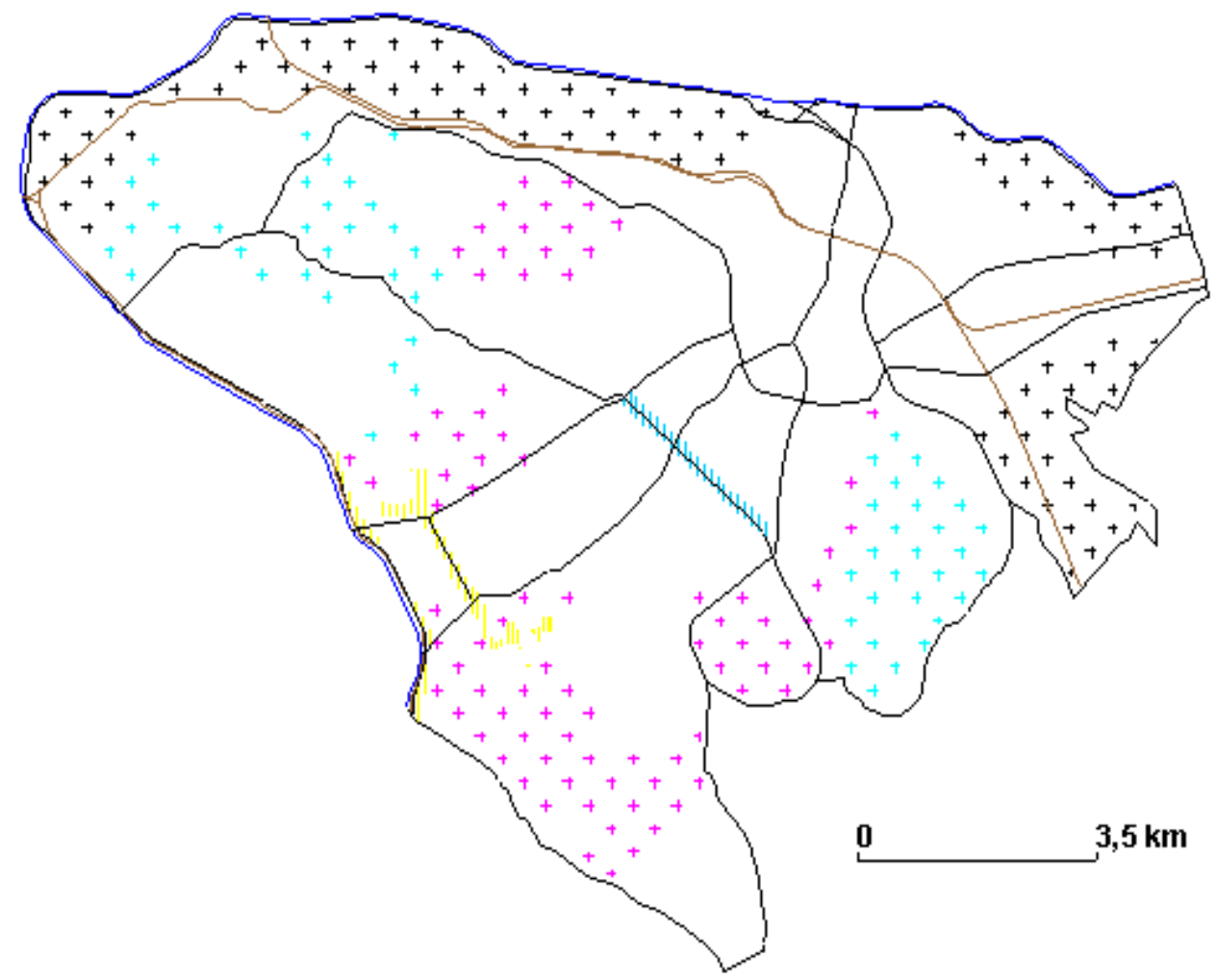

\section{TRANSFORMAÇÕES 1972-1999}

盂耑 MR para CS

R ou IR para CS

$R$ para RAC

RE para RAC

R ou RAC para AC

盂而 RE para RAC para AC

血 RE para RAC para CS

미 R para RAC para CS

H. IR para MI

ÁREA NÃO URBANIZADA EM 1999

*PARA MAIORES DETALHES CONSULTAR TEXTO DA DISSERTAÇÃO. INCLUI APENAS TRANSFORMAÇÕES NO TIPO DE USO E NÃO EM QUANTIDADE. PERÍMETROS APROXIMADOS, NÃO INCLUI CORREDORES COMERCIAIS SECUNDÁRIOS. USOS PREDOMINANTES, NÃO EXIBE PEQUENAS ÁREAS. ÁREAS DE LAZER INCLUÍDAS EM SEUS USOS LINDEIROS

MR= USO MISTO RESIDENCIAL/COMERCIAL LIGADO ÀS ATIVIDADES RURAIS

RE $=$ RESIDENCIAL HORIZONTAL DE ELITE

AC= APTO E COMÉRCIO/SERVIÇOS

RAC $=$ RESIDENCIAL HORIZONTAL COM APTOS E COMÉRCIO/SERVIÇOS

MI= MISTO INDUSTRIAL: IND OU RES+IND COM PRESENÇA DE APTOS E/OU COM/SERV

CS= COMÉRCIO/SERVIÇOS (CENTRO E SUBCENTRO)

IR= INDÚSTRIA OU INDÚSTRIA+RESIDENCIAL MODESTO

R= RESIDENCIAL MODESTO/CLASSE MÉDIA 


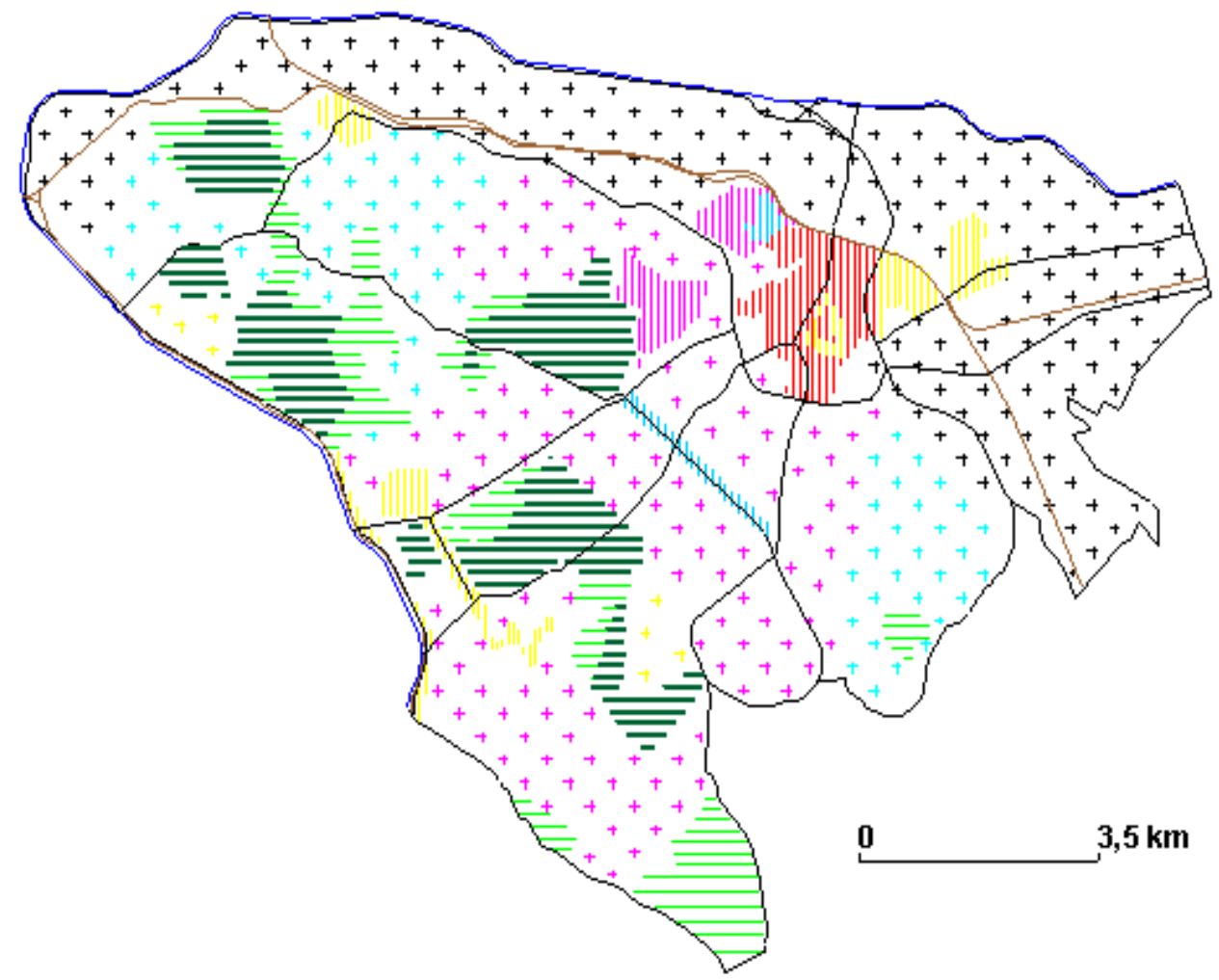

TRANSFORMAÇÕES 1860-1999

盂耑 MR para CS

R ou IR para CS

$R$ para RAC

RE para RAC

R ou RAC para AC

耑耑 RE para RAC para AC

而 RE para RAC para CS

Ull R para RAC para CS

IR para MI

ÁREAS RESIDENCIAIS DE CLASSE MÉDIA PRESERVADAS

ÁREAS RESIDENCIAIS DE ELITE PRESERVADAS

GRANDES PARQUES

*PARA MAIORES DETALHES CONSULTAR TEXTO DA DISSERTAÇÃO. INCLUI APENAS TRANSFORMAÇÕES NO TIPO DE USO E NÃO EM QUANTIDADE. PERÍMETROS APROXIMADOS, NÃO INCLUI CORREDORES COMERCIAIS SECUNDÁRIOS. USOS PREDOMINANTES, NÃO EXIBE PEQUENAS ÁREAS. ÁREAS DE LAZER INCLUÍDAS EM SEUS USOS LINDEIROS

$M R=$ USO MISTO RESIDENCIAL/COMERCIAL LIGADO ÀS ATIVIDADES RURAIS

RE= RESIDENCIAL HORIZONTAL DE ELITE

AC= APTO E COMÉRCIO/SERVIÇOS

RAC $=$ RESIDENCIAL HORIZONTAL COM APTOS E COMÉRCIO/SERVIÇOS

MI= MISTO INDUSTRIAL: IND OU RES+IND COM PRESENÇA DE APTOS E/OU COM/SERV

CS= COMÉRCIO/SERVIÇOS (CENTRO E SUBCENTRO)

IR= INDÚSTRIA OU INDÚSTRIA+RESIDENCIAL MODESTO

$\mathrm{R}=$ RESIDENCIAL MODESTO/CLASSE MÉDIA 


\section{CAPÍTULO 5 - CONCLUSÃO}

\section{1 - TRANSFORMAÇÕES DO TIPO 1, 2 E 3 (AUMENTO DE COMÉRCIO E} APARTAMENTOS EM ÁREAS NÃO INDUSTRIAIS)

O principal fator condicionante das transformações envolvendo o aumento do uso do solo comércio e serviços foi, obviamente, a existência de demanda. Como vimos nos capítulos anteriores, a demanda por comércio no período anterior ao desenvolvimento da economia cafeeira era muito pequena. Embora a cidade já tivesse alcançado algum desenvolvimento comercial graças ao fluxo de mercadorias entre o interior e o litoral, o reduzido tamanho da população, seu pequeno poder aquisitivo e o baixíssimo padrão de consumo da época, restrito quase que aos gêneros alimentícios ou de primeira necessidade, não determinavam uma demanda capaz de condicionar uma transformação no uso do solo mais intensa como a que viria a ocorrer no final do século XIX.

Com o café e o conseqüente surgimento de uma elite muito mais urbana e enriquecida surgiu uma demanda por produtos e serviços mais sofisticados. Esse primeiro crescimento da demanda foi responsável principalmente pela transformação do Triângulo em área comercial.

Com o crescimento populacional se mantendo em nível altos e, principalmente, com o aumento da classe média, a demanda por comércio e serviços se manteve em constante elevação, condicionando o surgimento e desenvolvimento de áreas comerciais. Esse crescimento populacional também 
criou maior demanda por habitação.

Segundo Décio Saes a classe média (classe de trabalho não manual, constituída principalmente por profissionais liberais e funcionários administrativos) começou a se formar no Brasil a partir de 1850 com a maior organização do Estado. Essa classe teve também algum crescimento graças ao café, pois essa nova economia exigia uma estrutura administrativa muito maior e mais organizada do que as atividades econômicas anteriores.

Entretanto, segundo o autor, essa classe realmente cresceu com o advento da indústria. Quantificar o fenômeno é um pouco difícil, principalmente devido ao fato de existirem inúmeras definições diferentes de classe média. Entretanto, para diversos autores, é fato que ela cresceu muito durante o século XX. Saes, por exemplo, aponta para 1920 um índice nacional inferior aos 3,5\% da população trabalhadora constituída por profissionais liberais e funcionários administrativos (SAES, D. 1985 p.5). Quadros, utilizando uma definição de classe média muito semelhante à de Saes (mas não rigorosamente idêntica, o que dificulta a comparação de dados) e utilizando-se de dados mais precisos obtidos nos censos demográficos do IBGE apontava um índice de $24,5 \%$ de profissionais de classe média em relação à população economicamente ativa urbana do país para 1950 e 31,7\% em 1980 (QUADROS, W. 1991 tab1 s/p). Além do crescimento numérico das classes médias e populares também houve uma drástica alteração dos padrões de consumo na sociedade brasileira. Se durante o século XIX o consumo se restringia a gêneros básicos como alimentação e vestuário, mesmo para as elites, hoje até mesmo as classes populares já têm acesso a uma série de novos bens advindos com o progresso tecnológico e as facilidades proporcionadas pelos sistemas de compra a 
crédito desenvolvidas nos últimos sessenta anos, como geladeira, fogão, televisão, videocassete, aparelho de som, máquina de lavar roupas, automóvel, criando uma demanda maior para o comércio. Ao analisarmos através dos dados do IBGE, por exemplo, o caso dos fogões, eletrodoméstico considerado hoje imprescindível, veremos o extraordinário crescimento nas vendas desse bem. Em 1960, por exemplo, havia um número de 13.474.472 domicílios particulares permanentes no país, sendo que apenas 2.467.257 (18,31\%) possuíam fogão a gás; em 1970 o número de domicílios já era igual a 18.086.336 sendo 7.656 .891 (42,33\%) com fogão a gás. O caso dos televisores também é um exemplo interessante. Se nos anos 50 a TV, recém lançada no Brasil era um bem adquirido por poucos privilegiados, aos poucos foi crescendo o número de famílias a adquiri-la. Segundo o IBGE em 1980, por exemplo, 56,09\% dos domicílios particulares permanentes possuíam televisão. Esse número se elevou para 79,60\% em 1991 e 81,02\% em 1995. No caso de outros bens, em 1995 82,71\% dos domicílios brasileiros possuíam radio; 28,47\% automóvel e 26,61\% máquina de lavar. Até mesmo bens de lançamento mais recente como o freezer, em 1995 já era encontrado em 15,38\% dos domicílios brasileiros, números que tendem a ser bem maiores no caso do Estado de São Paulo e Município da capital, regiões tradicionalmente bem mais desenvolvidas (IBGE . Anuários Estatísticos, diversos anos).

Outro fator importante que condicionou o aumento da demanda para o setor de comércio e serviços foi a inserção da mulher no mercado de trabalho, pois com isso uma série de atividades executadas de forma artesanal e familiar passou a demandar (por falta de tempo, mas também por uma exigência maior de qualidade), uma execução profissional. Em 1940 no Brasil, segundo Mello 
apenas $14 \%$ da força de trabalho era feminina (MELLO, M. 1982 p.20). No Estado de São Paulo 21,86\% (COSTA, L. 1982 p.9). Recentemente dados publicados pelo IBGE no Anuário Estatístico do Brasil nos informam que em 1995 mais de $40 \%$ da população economicamente ativa brasileira era constituída por mulheres (IBGE Anuário Estatístico 1995).

As intensas transformações socioeconômicas ocorridas nas últimas décadas (fim da guerra fria, globalização, reorganização do trabalho, aumento da necessidade de escolarização, grande desenvolvimento tecnológico, etc.) também se refletiram no aumento da demanda por comércio e serviços, pois a cidade foi adquirindo com seu desenvolvimento econômico também grande importância nas áreas educacional, de saúde, comunicações e tecnologia, geradores de atividades principalmente no setor de serviços. São Paulo é hoje, por exemplo, a cidade brasileira com maior número de shopping centers, universidades e hospitais. É o maior mercado publicitário e o maior gerador de pesquisas científicas do país, além de ser a sede da bolsa de valores, de principais bancos e empresas e grande pólo de turismo de negócios (EMPLASA 1994 p.43).

Além da existência da demanda, outro fator importante para instalação do uso comercial é a boa acessibilidade. O primeiro setor especializado em comércio e serviços, de elite principalmente, surgiu no Triângulo, de onde partiam todas as principais vias de acesso da cidade. Além disso o Triângulo era o local da cidade melhor servido por transportes. Todos os subcentros populares surgiram em pontos estratégicos de transportes coletivos para amplas regiões do Município de São Paulo e da Grande São Paulo habitadas pelas classes populares, como o Brás (zona leste), Pinheiros (zona sudoeste), Lapa (zona 
noroeste) e após os anos 60 , com a saída do comércio de elite, a região do centro tradicional.

É importante observar a necessidade de fácil acesso para um número maior de compradores para o desenvolvimento de subcentros populares. Inúmeros pequenos subcentros de comércio local surgiram nos pontos mais importantes de cada bairro, principalmente nos pontos que de alguma forma condensavam o fluxo de pessoas, como largos de igrejas, pontos finais de ônibus, estações de trem. Entretanto esses subcentros mantiveram-se como subcentros locais, não alcançando o grande desenvolvimento do Brás, Lapa ou Pinheiros, Uma hipótese que pode explicar tal fato é o poder aquisitivo menor das classes populares, o que faz com que o desenvolvimento de grandes subcentros populares necessite de um número maior de compradores.

O fator acesso aos bairros de elite, principalmente por automóvel mostrou fortes evidencias de ser um fator condicionante para instalação de comércio. $O$ comércio de elite se deslocou do Triângulo para a Cidade Nova e depois para a Avenida Paulista acompanhando o uso residencial de elite e abandonando a área congestionada do Triângulo expandindo-se a seguir para a região dos Jardins, Itaim e Moema. O aumento do uso do automóvel, em um primeiro momento utilizado pela elite, posteriormente também pela classe média e atualmente até mesmo pelas classes populares, foi apontado por alguns autores como um dos fatores mais importantes para a maior distribuição do comércio em toda a área de estudo, por flexibilizar o acesso. Ao analisarmos os dados da Pesquisa Origem Destino do Metrô podemos perceber que o aumento generalizado de comércio e serviços na área de estudo coincide com o aumento de uso de automóveis. 
Viagens por transporte individual na Grande São Paulo (METRÔ PESQUISA OD-97 $1997 \mathrm{~s} / \mathrm{p})$

$1967-32 \%$

$1977-39 \%$

$1987-45 \%$

$1997-49 \%$

Taxa de motorização na GSP (METRÔ PESQUISA OD-97 1997 s/p)

$1967-70$

$1977-135$

$1987-141$

$1997-187$

A taxa de motorização (número de automóveis por mil habitantes) para o Município de São Paulo cresceu de 158 em 1987 para 197 em 1997 A possibilidade de estacionamento e de modernização dos edifícios também pode ser um dos fatores responsáveis pelo esvaziamento do centro histórico em função de novos subcentros comerciais e de serviços. Dados recentes da EMPLASA (EMPLASA, $2000 \mathrm{~s} / \mathrm{p}$ ) nos mostram que enquanto o cento histórico possui 1 vaga de garagem para cada 575,4 m2 de área útil de escritórios, a avenida Faria Lima possui 64,4 m2, a avenida Berrini (fora da área de estudo) 44,4 m2 e a avenida Marginal Pinheiros 38,4 m2. O padrão internacional, segundo a EMPLASA é de 25 a $30 \mathrm{~m} 2$.

A valorização dos terrenos provoca também a expulsão dos usos residenciais e a ocupação do território por novos usos. Podemos observar através dos mapas de Souza (SOUZA, M. 1994) que a valorização dos imóveis coincide com as áreas de maior transformação de uso do solo. 


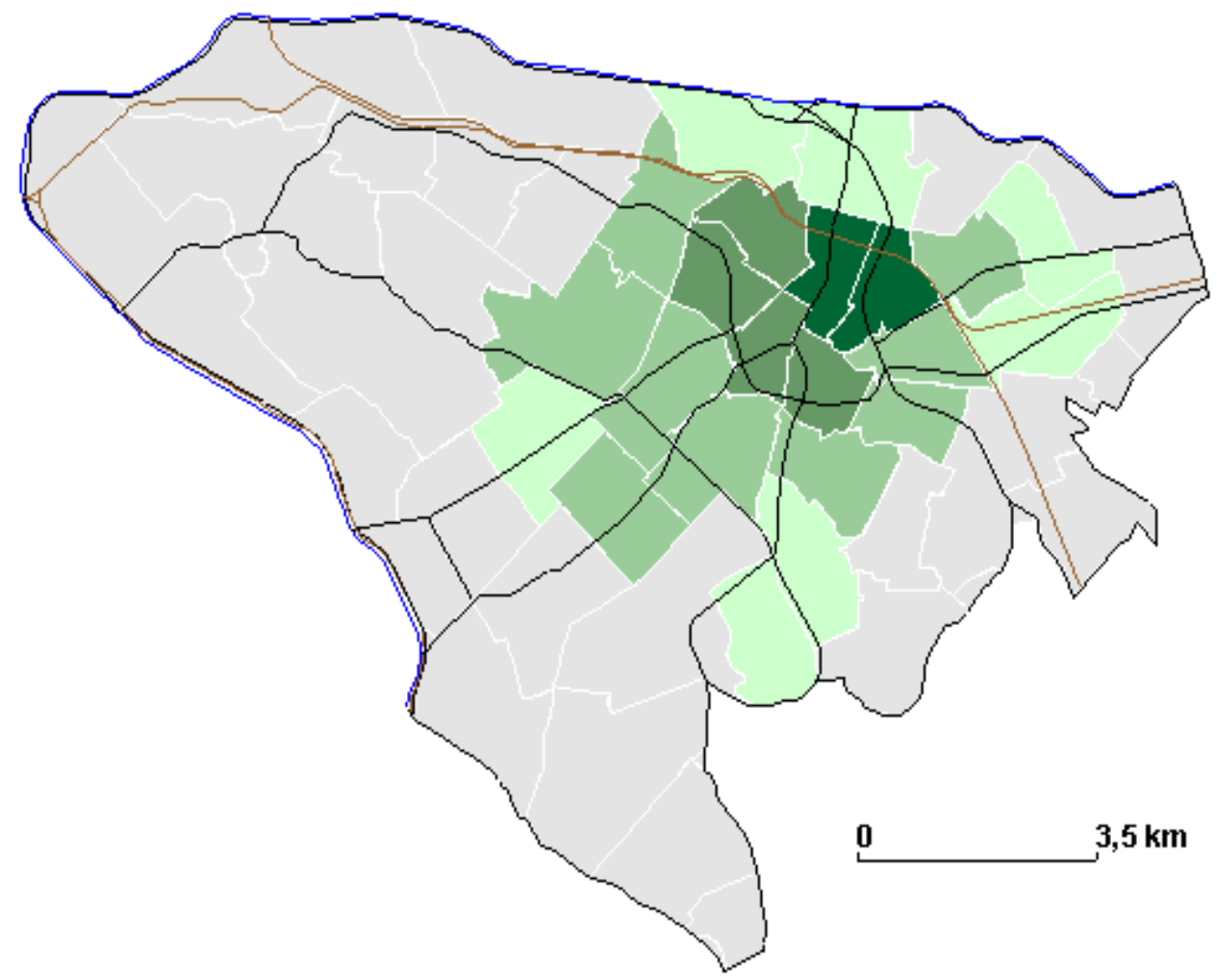

VALOR VENAL 1938(*) / TOTAL POR SETOR FISCAL

$44,00-226,00$

$30,00-44,00$

$20,00-30,00$

$13,00-20,00$

ABAIXO DE 13,00 OU ÁREA NÃO URBANIZADA

FONTE: SOUZA, M. 1994

*EM MIL RÉIS 


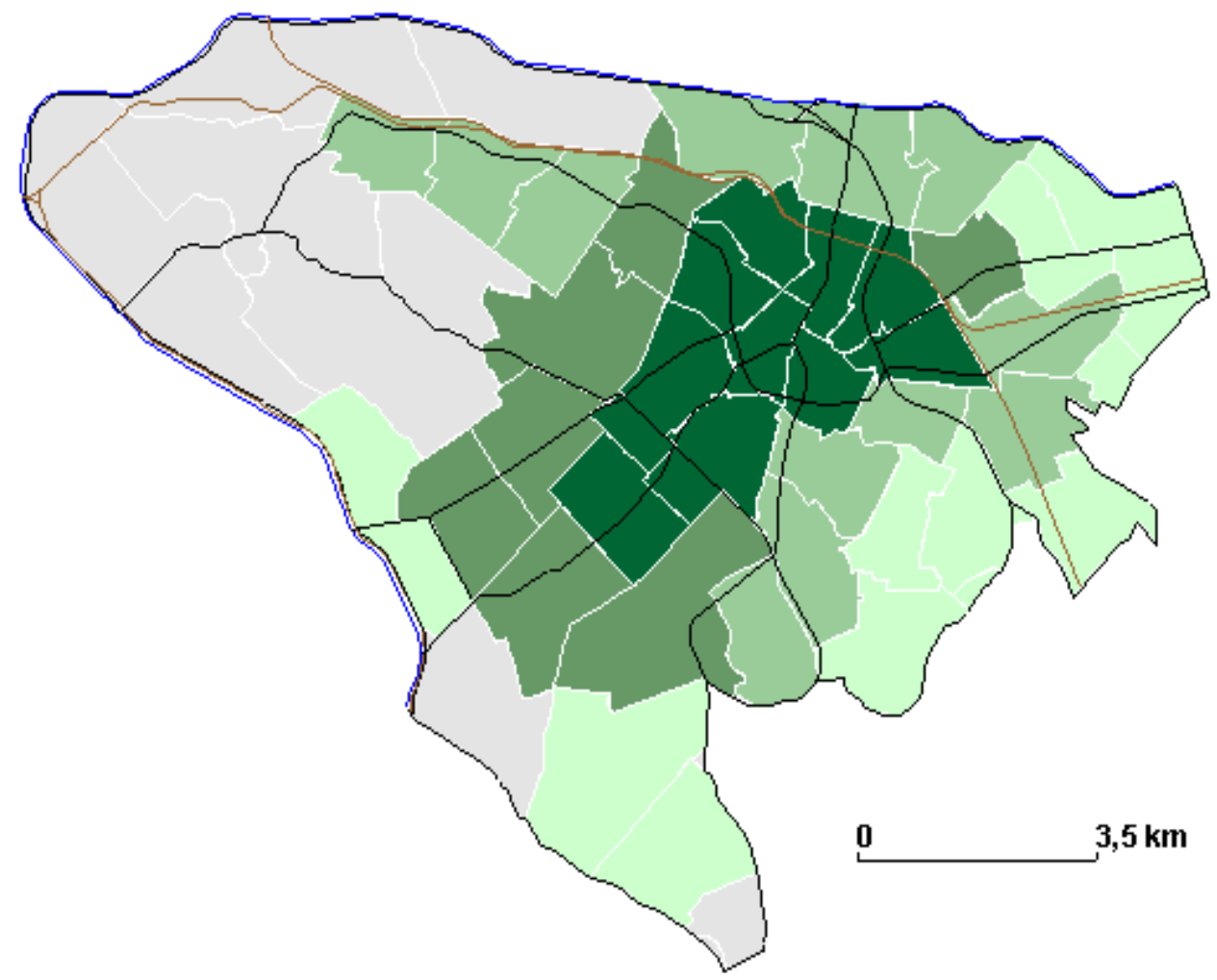

VALOR VENAL 1966(*) / TOTAL POR SETOR FISCAL

$600 \$ 000-1100 \$ 000$

$200 \$ 000-600 \$ 000$

$60 \$ 000-200 \$ 000$

$50 \$ 000-60 \$ 000$

ABAIXO DE 50\$000 OU ÁREA NÃO URBANIZADA

FONTE: SOUZA, M. 1994

* EM CRUZEIRO 


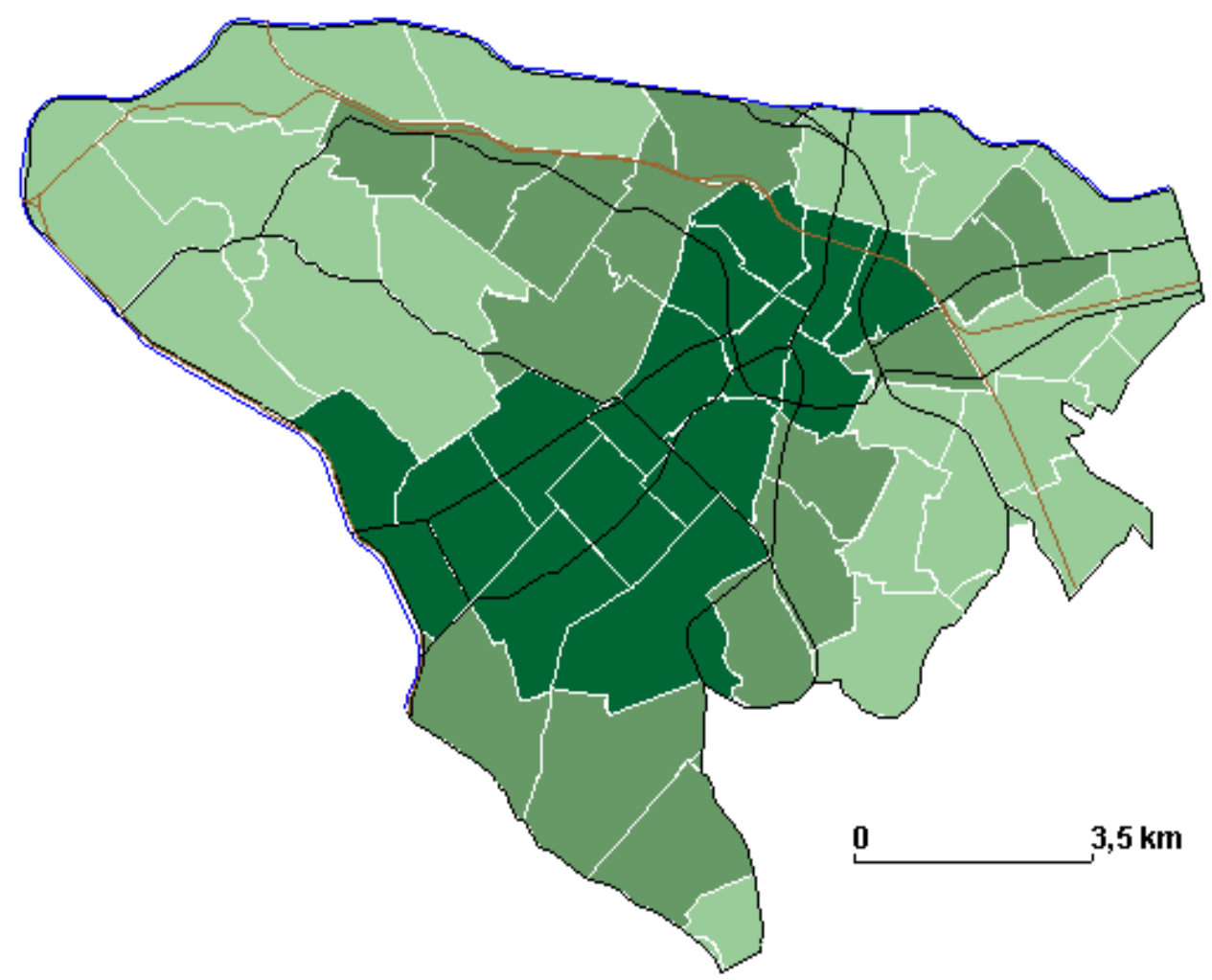

VALOR VENAL $1987\left(^{*}\right)$ / TOTAL POR SETOR FISCAL

$1000,00-3000,00$

$500,00-1000,00$

$300,00-500,00$

$200,00-300,00$

ABAIXO DE 200,OO OU ÁREA NÃO URBANIZADA

FONTE: SOUZA, M. 1994

* EM CRUZADO 
A existência de legislação estritamente residencial em alguns bairros de elite também chegou a ser apontada por alguns autores como um fator de desenvolvimento das áreas comerciais em áreas próximas e não protegidas por legislação, pois ao impedir a localização até mesmo do comércio local essa legislação provocou um deslocamento da demanda, normalmente de poder aquisitivo alto (uma vez que a legislação estritamente residencial quase sempre foi instalada em bairros de elite ou classe média). Ao analisarmos os mapas de legislação e uso do solo podemos ver que há uma proximidade de usos comerciais/serviços dos bairros de elite protegidos por legislação. É importante observar também o grande e rápido crescimento dos subcentros comerciais de elite, em parte justificado pela maior capacidade de consumo das classes de renda mais alta. Esses subcentros têm uma capacidade muito maior de atrair atividades complexas de administração (públicas ou privadas, como sede de empresas, consulados e representações comerciais estrangeiras, sede de bancos, associações profissionais e empresarias, etc.) do que os subcentros populares.

O grande fator condicionante da verticalização residencial também foi a existência da demanda. O crescimento de classe média, já analisado nos parágrafos anteriores, criou uma demanda por habitação ávida por uma localização privilegiada em relação às classes populares e com poder aquisitivo suficiente para comprar essa localização. Ao analisarmos os mapas síntese dos dados podemos verificar que a verticalização residencial ocorreu prioritariamente nos bairros próximos ou de fácil acesso a determinados pontos em cada período histórico, normalmente os pontos considerados mais importantes em cada período. É possível observar que o uso residencial 
vertical ocorreu primeiramente nos bairros próximos ao centro histórico: Higienópolis, Paulista, Bela Vista, Liberdade, Santa Cecília, etc. ainda antes da década de 50, quando ele era o principal ponto de interesse da cidade, o local com maior número de empregos, principalmente de classe média, o local onde se instalava o comércio de elite, órgãos públicos, sede de bancos e empresas. Após os anos 70, com o deslocamento das atividades de elite para a avenida Paulista, a verticalização residencial deslocou-se principalmente para a região sudoeste, criando uma ampla região de uso residencial vertical e comércio.

A valorização dos terrenos, como mostrou Maria Adélia de Souza (SOUZA, M. 1994 p.170) também é um fator condicionante importante, ao provocar, dentre outras coisas, a necessidade de criação de novos pavimentos para diluição dos custos do terreno. Podemos ver através da comparação entre os mapas de uso do solo e de valorização uma coincidência entre valorização e verticalização.

Outros fatores importantes para a verticalização foram o desenvolvimento da técnica, que permitiu a construção dos edifícios, e uma mudança no padrão cultural, com uma aceitação maior do apartamento como forma de morar. A importância do fator cultural na verticalização residencial também pode ser observada pela atração que bairros de classe média e de elite exercem sobre ela, onde além das boas condições ambientais (infra-estrutura, acesso, etc.) também conta o valor social da área, o status, muito bem explorado pelo mercado imobiliário, ao chamar, por exemplo, Santa Cecília de Higienópolis ou Vila Hamburguesa de Alto da Lapa para que o apartamento ganhe mais status junto a seus compradores em potencial. 
A legislação contribuiu para a verticalização apenas comercial, pois chegou a estabelecer alturas mínimas para edifícios construídos em algumas ruas do centro tradicional, que, entretanto, já apresentavam forte demanda para essa verticalização comercial. Para a verticalização residencial a legislação não teve grande papel incentivador como já observou Wakisaka, servindo apenas como elemento a restringir sua instalação em bairros de elite. Como veremos adiante essa legislação restritiva foi paulatinamente revogada em muitos bairros, principalmente nos bairros de classe média (WAKISAKA, T. 1991 P.219).

Um fator importante para a verticalização residencial foi a política habitacional, que através de financiamentos, conseguiu viabilizar a compra de imóveis pela classe média num período em que seu poder aquisitivo entrou em declínio. Segundo Caldeira, entre 1977 e 1982 80,8\% dos apartamentos lançados no Município de São Paulo possuiam algum tipo de financiamento (CALDEIRA, T. 2000 p.226). Em 1998, segundo a EMBRAESP, 45\% dos apartamentos a preço fechado construídos possuíam algum tipo de financiamento, em 1999 43\% e em 2000 42\%. Destes, financiados pelo Sistema Financeiro da Habitação temos 26\% em 1998, 29\% em 1999 e 20\% em 2000. Esses valores, somados aos recursos da Caixa Econômica Federal chegam a 38\% em 1998, 68\% em 1999 e 82\% em 2000 (EMBRAESP 2001 p.13).

A respeito da infra-estrutura, não foram encontrados dados que pudessem desmentir a relação entre a existência de infra-estrutura e verticalização, pois as informações encontradas sugerem que a infra-estrutura precede em muitos anos a construção de apartamentos. As primeiras áreas a se verticalizarem, próximas ao centro histórico já possuíam água, esgoto e iluminação em 1900, 
como nos mostra Rolnik (ROLNIK, R. 1997 mapa 15). As áreas que se verticalizaram após 1972 também possuíam boa infra-estrutura como nos mostrou o PUB (Plano Urbanístico Básico) em 1968 (SÃO PAULO (PMSP) 1969 - mapas de infra-estrutura 1968 V.5 p.10, p. 65, p.85, p.137). Dados de Mascaró obtidos através dos Censos do IBGE por Administrações Regionais para 1970 mostram que as Ars (Administrações Regionais) de Pinheiros, Lapa e Sé (inteiramente incluídas na área de estudo) apresentam respectivamente 98,5\%-86,5\%-100,0\% de áreas pavimentadas; $100,0 \%-80,0 \%-100 \%$ de áreas iluminadas; $100,0 \%-75,5 \%-99,1 \%$ de áreas com esgoto, $100,0 \%-74,9 \%$ 100,0\% de áreas com água e 47,7\%-23,5\%-86,4\% áreas com gás (MASCARÓ, J. 1979 P.236). Entretanto, para uma conclusão definitiva a esse respeito é necessário obter dados mais detalhados sobre uma área de estudo maior do que a área desta dissertação. 


\section{2 - TRANSFORMAÇÕES DO TIPO 4 (DIMINUIÇÃO DO USO INDUSTRIAL)}

Como vimos nos capítulos anteriores o desenvolvimento da indústria no Município de São Paulo iniciou-se ainda no século XIX alcançando notável crescimento até o início do último quartel do século XX. Enquanto a demanda industrial permaneceu alta no Município, a indústria ocupou prioritariamente áreas vazias (instalação de novos usos), primeiro nas proximidades das ferrovias e depois rodovias, constituindo além das áreas industriais, áreas industriais e residenciais operárias . O único caso em que as indústrias chegaram a substituir algum outro uso dentro da área de estudo foi no caso do Triângulo (bem no início do processo de industrialização, quando as indústrias ainda possuíam um caráter semi-artesanal) e no Bom Retiro e imediações, uma região já de uso misto industrial, onde algumas indústrias substituíram, segundo Dertônio, algumas residências. Essas indústrias, principalmente de confecção, extremamente pequenas, de caráter quase artesanal e muitas vezes com uso de mão de obra familiar, estavam ligadas principalmente ao comércio de vestuário. Segundo Dertônio, a principal razão da instalação dessas indústrias ligadas ao comércio foi o afastamento das residências e desvalorização da área provocada pelo confinamento da prostituição promovido pela administração pública nos anos quarenta, um caso particular e em pequena escala, mas que exemplifica bem a influência do fator cultural na repulsão de um uso sobre outro (DERTÔNIO, H. 1971 p.69).

A principal transformação no uso do solo relacionado à demanda industrial foi mesmo a substituição dos antigos usos industriais ou residenciais operários em áreas de uso misto industrial com diminuição do uso industrial e aumento de uso comercial/serviços e apartamentos. 
Esse tipo de transformação, que se intensificou recentemente, está associada à diminuição da demanda industrial, a chamada desconcentração industrial, ao crescimento da demanda por outros usos e a melhora das condições ambientais oferecidas por essas áreas capazes de atrair esses novos usos, (como a melhoria da acessibilidade, com a construção, por exemplo, de novas vias e pontes, o controle de enchentes, a melhoria na infra-estrutura) e a própria influência de bairros vizinhos já com outras atividades e até mesmo maior "status" social.

Dados do SEADE para os anos de 1985 e 1997 nos mostram a queda no número de pessoas ocupadas no setor industrial no Município de São Paulo: Evolução recente pessoas ocupadas (Pessoas ocupadas, segundo setor de atividade econômica do trabalho principal 1985/1997 em porcentagem) 1985

indústria de transformação - 29,8\%

serviços - $44,0 \%$

comércio - 14,7\%

construção civil - 3,0\%

serviços domésticos - 8,1\%

outros - $0,2 \%$

1997

indústria de transformação- 19,1\%

serviços - $52,4 \%$

comércio - 17,2\%

construção civil - 2,7\%

serviços domésticos - 8,3\% 
outros - $0,4 \%$

Fonte: www.seade.sp.gov.br

A desconcentração industrial, provocando a diminuição da pressão da demanda por uso industrial ainda é um assunto polêmico, não havendo um consenso entre os pesquisadores sobre suas causas. Paul Singer aponta como um fator condicionante a valorização dos terrenos no Município de São Paulo (SINGER, P. 1967 p.79). Explica o autor que as indústrias, como qualquer outro setor da sociedade, procuram se instalar nos locais mais adequados ao desempenho de suas atividades, contudo, segundo Singer a vantagem locacional deve superar o preço da terra, um fator importante se levarmos em conta o fato de que a maioria das indústrias necessita de grandes instalações. Por esse motivo as indústrias instalaram-se prioritariamente em áreas vazias próximo às ferrovias, onde além da facilidade de transporte havia a abundância de água e o preço baixo dos terrenos que haviam sido desprezados por outros usos em razão da insalubridade dos mesmos, provocada pelas constantes enchentes. Com a ocupação dessas áreas e as obras realizadas e a instalação de usos residenciais, as mesmas tendem a se valorizar, o que fez o setor industrial procurar novas regiões mais distantes da localização ideal, mas com preços compensadores. Ao realizarmos uma comparação entre os mapas de Souza sobre a valorização e os mapas de transformações no uso do solo podemos observar que essas áreas realmente sofreram valorização.

Nas últimas décadas a diminuição da demanda industrial na área de estudo também foi incentivada pela própria reorganização da economia mundial, levando alguns ramos industriais mais antigos à rápida obsolescência e ao 
fechamento. Essa necessidade de modernização dos antigos parques industriais provocados pelas novas formas de produção alcançadas pelo grande desenvolvimento tecnológico das últimas década tornou muito mais vantajoso para a indústria transformar suas antigas sedes em capital aplicável em modernização através da venda de seus terrenos, já valorizados, para novos usos, para os quais a vantagem da localização supera o preço desses terrenos. 


\section{3 - TIPO 5 (PRESERVAÇÃO DE ALGUNS BAIRROS RESIDENCIAIS HORIZONTAIS)}

Alguns bairros residenciais, de elite (Campos Elíseos, Higienópolis, etc.) ou não (Santa Cecília, Pinheiros, Itaim, etc.), mantiveram-se preservados por algum tempo para depois sofrerem algum tipo de transformação. Outros bairros, alguns bem antigos (Pacaembú, Jardim América, Jardim Europa) encontram-se em razoável estado de conservação (ou seja, com transformações nos corredores ou em pequenas áreas), embora o entorno da maioria desses bairros tenha sofrido grandes transformações.

No primeiro caso a preservação dos bairros se justifica por baixa demanda ou deficiências nas condições oferecidas por essas áreas para atender as demandas existentes e a disponibilidade de outras áreas com melhores condições para atender a essas demandas. A presença de enchentes, a distância ao centro, dificuldades de acesso, as deficiências de infra-estrutura (água, esgoto, iluminação, transportes, etc.), o baixo poder aquisitivo dos moradores e outros fatores dificultaram, por exemplo, a instalação de áreas comerciais e de apartamentos frente à concorrência de outras áreas com melhores condições disponíveis. Nem mesmo o baixo custo dos terrenos e a ausência de legislação restritiva incentivaram a instalação de novos usos. Quando esses fatores deixaram de existir, quer pela melhoria da infraestrutura, obras viárias ou pelo esgotamento ou excessiva valorização de outras áreas, essas antigas áreas desprezadas passaram a receber novos usos.

Já no segundo caso, da preservação dos bairros residenciais de elite e classe média essa justificativa (principalmente de baixa demanda) foi parcialmente 
válida apenas nos primeiros anos desses bairros, pois seu entorno também não havia sofrido as profundas transformações atuais.

Uma das causas prováveis dessa relativa conservação é a legislação. Os primeiros bairros residenciais horizontais de elite, loteados ainda no final do século XIX, Campos Elíseos e Higienópolis, sofreram grandes transformações com aumento de uso comercial e de apartamentos. Notamos que tais bairros foram pouco protegidos pela legislação, que quando da fundação dos mesmos eram instrumentos pouco utilizados.

Bairros de classe média também chegaram a ter legislação restritiva a outros usos não residenciais, como o Jardim Paulista, a Aclimação e outros, entretanto, ela também foi sendo revogada ao longo dos anos. Alguns bairros residenciais horizontais de elite, como o Jardim América, o Alto da Lapa, construídos pela Cia City possuíram restrições particulares constantes no contrato estabelecendo, sobretudo, as condições de ocupação para garantir as qualidades urbanísticas, e que envolviam quase sempre a proibição de instalação de usos diferentes do uso residencial horizontal. Essas restrições foram incorporadas em sua maioria à legislação oficial. Há casos, fora da área de estudo, como o bairro popular do Jaguaré, em que essas restrições simplesmente não foram obedecidas e foram revogadas principalmente pela lei de zoneamento e modificações que consideraram o fato de que contratos particulares não poderem se sobrepor à legislação dos poderes públicos.

Esses bairros residenciais de elite e classe média alta sofrem constante pressão por modificações na legislação e seus moradores estão razoavelmente organizados contra essas alterações. Entretanto, só essa 
mobilização parece não ser suficiente em todos os casos, pois mobilizações de moradores de bairros de classe média não têm sido tão eficientes na manutenção das características de seus bairros, como ocorreu recentemente com os moradores das imediações do prolongamento da avenida Faria Lima. Entretanto, os moradores dos bairros residenciais horizontais de elite têm sido capazes de barrar tais modificações, o que nos leva a concluir que a legislação é um instrumento eficaz na preservação do uso do solo de um bairro desde que seus moradores tenham o poder de vê-la aplicada, fiscalizada e não alterada e desde que esse poder seja mais forte do que o poder das outras demandas. 


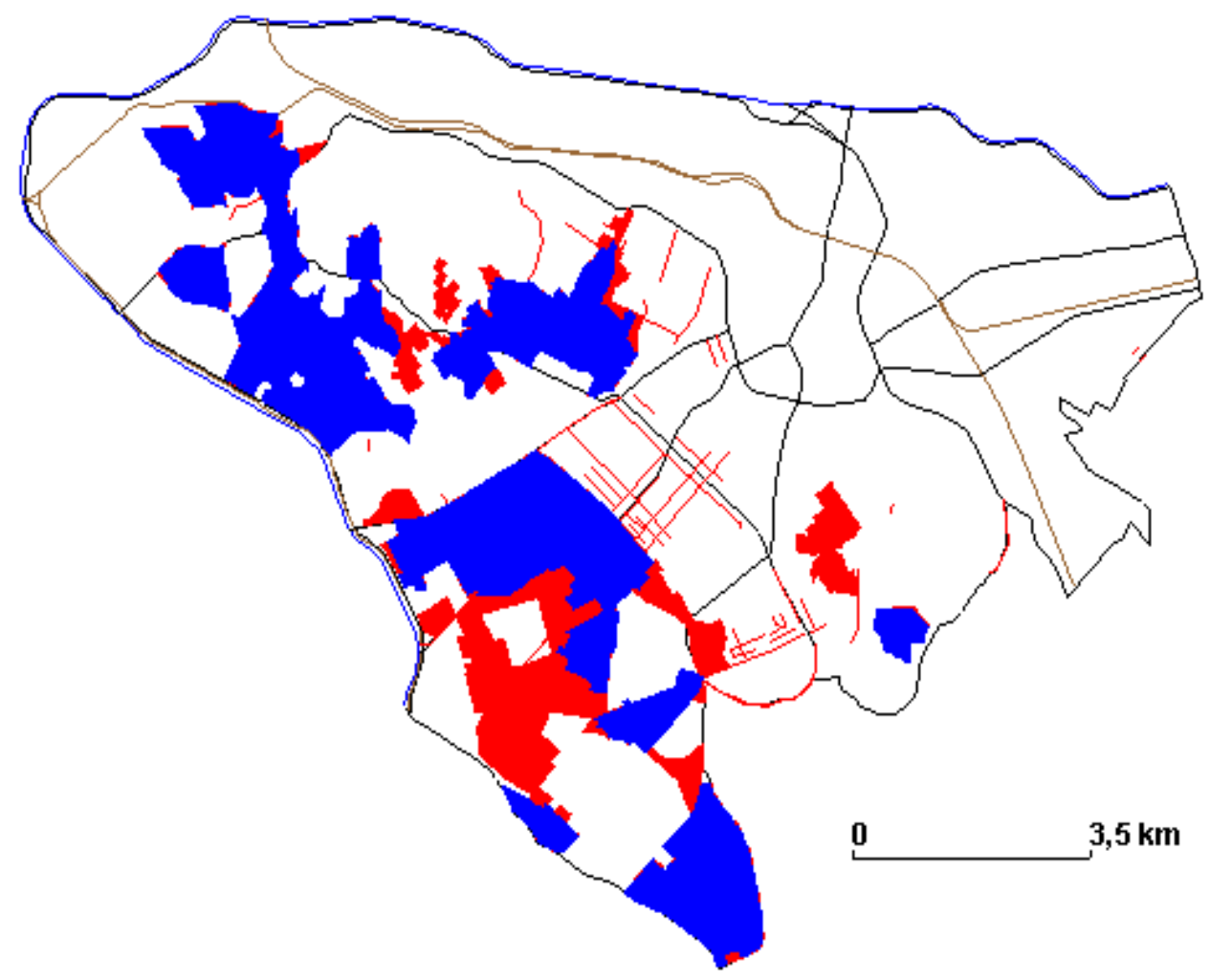

ÁREAS ESTRITAMENTE RESIDENCIAIS (APTO NÃO PERMITIDO) 1922/1999 REVOGADAS

PARA VER DATA DE REVOGAÇÃO E EXCEÇÕES, COMO NÚCLEOS E CORREDORES COMERCIAIS PERMITIDOS CONSULTAR ÍNTEGRA DA LEGISLAÇÃO 


\section{4 - CONSIDERAÇÕES FINAIS}

Através da análise dos capítulos anteriores podemos concluir que, realmente, a transformação do uso do solo é um processo coordenado principalmente pela demanda (ou procura pelo espaço) e a oferta (ou disponibilidade de espaço). Contudo, uma série de fatores condiciona essa relação entre demanda e oferta.

Para haver transformação é necessário haver demanda. Essa demanda não se distribui uniformemente sobre o território, procurando dentre as ofertas disponíveis aquela que melhor atenda suas necessidades. Essas necessidades, bem como todas as características de demanda e oferta variam ao longo do tempo, condicionadas principalmente pelas transformações socioeconômicas tais como alterações políticas, de valores culturais, desenvolvimento tecnológico, etc. A questão da acessibilidade a pontos estratégicos do território (principalmente centros comerciais e bairros residenciais de elite), entretanto, foi um fator presente em inúmeros casos no período e área estudados.

Enquanto a demanda persiste e a qualidade da oferta atende satisfatoriamente às necessidades dessa demanda, a transformação continua se expandindo. Algumas áreas podem, portanto, ficar livre das transformações por deficiências na oferta. A transformação cessa ou diminui se a demanda diminui ou deixa de existir ou se a oferta deixa de atender tais necessidades da demanda ou ainda, se surgem outras ofertas com melhores condições em um novo lugar. Nesse caso, a demanda se desloca para esse novo lugar, abrindo espaço para ação de outras demandas no antigo território, para as quais o espaço 
apresenta qualificação suficiente. Há, portanto, um complexo sistema de atração e repulsão entre os diversos usos envolvendo tanto uma competição entre as diversas demandas pela melhor oferta como entre as diversas áreas disponíveis e seus proprietários (oferta) pela demanda.

Essa competição é regulada principalmente pelas regras sócioeconômicas: as regras de mercado e dos poderes públicos. Cada setor da sociedade possui uma força, ou capacidade de competição, diferente (por exemplo, maior capital financeiro para comprar a melhor oferta). Os setores com menor força são obrigados a se adaptar às condições não tão favoráveis, abrindo mão de seus padrões de exigência, enquanto os setores com maior força ficam com as melhores opções disponíveis, podendo inclusive promover adaptações no território para adequá-los a suas exigências.

Essas regras de mercado e dos poderes públicos (legislação, planejamento, administração) são fruto da sociedade que as criou (ANDRADE, F 1966 p.8, p.132). Dessa forma, esses setores em conflito disputam também o poder de controlar esses instrumentos de mediação. Assim, nem sempre esses instrumentos são usados de maneira tecnicamente correta, o que explica a existência de planos não executados, demandas não atendidas (como no caso da habitação popular), legislação não fiscalizada, especulação imobiliária. A transformação do uso do solo em áreas residenciais é um processo, que ocorre com maior ou menor velocidade de acordo com a intensidade dos fatores transformadores. Muitas vezes esse processo pode ser benéfico aos interesses da cidade e dos moradores das áreas afetadas, representando uma renovação nas funções do bairro e impedindo a deterioração de sua qualidade de vida. Entretanto, deve ser sempre controlado, por exemplo pelo controle 
dos fluxos urbanos, o controle do valor de terrenos e imóveis, políticas públicas de atendimento às demandas negligenciadas pelo mercado, etc. A legislação pode ser um instrumento eficaz na preservação do uso do solo de um bairro residencial, desde que seus moradores tenham o poder de vê-la aplicada, fiscalizada e não alterada e desde que esse poder seja mais forte do que o poder das outras demandas. 


\section{6 - REFERÊNCIAS BIBLIOGRÁFICAS}

AMARAL, Antonio Barreto do. Bairro de Pinheiros. 3.ed. São Paulo, Prefeitura do Município de São Paulo, 1985. (Série História dos bairros de São Paulo, v.2).

ANDRADE, Francisco de Paula de. Subsídios para estudo da influência da legislação na ordenação e na arquitetura das cidades brasileiras. São Paulo, 1966. Tese (Provimento de Cátedra) - Escola Politécnica, Universidade de São Paulo.

ANDRADE, Margarida Maria. Brás, Moóca e Belenzinho - "bairros italianos" na São Paulo além Tamanduateí. Revista do Departamento de Geografia, p.97102, 1994.

Bairros além Tamanduateí. São Paulo, 1991. Dissertação (Mestrado) - Faculdade de Filosofia, Letras e Ciências Humanas, Universidade de São Paulo.

ARAÚJO FILHO, José Ribeiro. Dentre os centros urbanos mais procurados, a capital paulista esteve sempre em primeiro lugar. In: EMPRES

METROPOLITANA DE PLANEJAMENTO DA GRANDE SÃO PAULO.

Reconstituição da memória estatística da Grande São Paulo. São Paulo, Empresa Metropolitana de Planejamento da Grande São Paulo, 1981. v.2. p.95.

AZEVEDO, Aroldo Edgard de, coord. A cidade de São Paulo: estudos de geografia urbana. São Paulo, Companhia Editora Nacional, 1958. 4v.

AZEVEDO NETTO, Domingos Theodoro. Uso do solo. In: EMPRESA METROPOLITANA DE PLANEJAMENTO DA GRANDE SÃO PAULO.

Diagnóstico 75. São Paulo, s.ed., 1976.

BACELLI, Roney. Jardim América. São Paulo, Prefeitura do Município de São Paulo, 1982. (Série História dos bairros de São Paulo, v.20)

BARRETO, Jule. A lógica da cidade clandestina. Urbs, p.28, nov. 1997.

BRITO, Roberto A. Correa. Cadastro Immobiliário de São Paulo. São Paulo, União Brasileira de Imprensa, s.d.

BRUNA, Gilda Collet. Localização comercial na Grande São Paulo. Sinopses, n.5, p.89, jun.1984. 
BRUNO, Ernani da Silva. História e tradições da cidade de São Paulo. Rio de Janeiro, José Olympio, 1954. 4v.

CALDEIRA, Teresa Pires do Rio. Cidade de Muros, crime, segregação e cidadania em São Paulo. São Paulo, EDUSP/Editora 34, 2000.

CAMPANA, Isaura Regina Ferraz Parente. Relações entre a legislação de uso e ocupação do solo e o espaço urbano local: subsídios para o planejamento de bairros. São Paulo, 1989. Dissertação (Mestrado) - Escola Politécnica, Universidade de São Paulo.

CESAD-FAUUSP/PMSP. TPCL 1971. São Paulo, CESAD-FAUUSP, s/d. TPCL 1990. São Paulo, CESAD-FAUUSP, s/d.

CHORLEY, R; HAGGETT, P. La Geografia y los modelos socioeconomicos. Madrid, Instituto de Estudios de Administracion Local, 1971.

CORDEIRO, Helena Kohn. A cidade mundial de São Paulo e a recente expansão de seu centro metropolitano. São Carlos, UNESP, 1993.

O centro da metrópole paulistana: expansão recente. São Paulo, 1980. Tese (Doutorado) - Departamento de Geografia da Faculdade de Filosofia, Letras e Ciências Humanas, Universidade de São Paulo.

COSTA, Letícia Borges. A participação da mulher no mercado de trabalho: o caso do Estado de São Paulo. São Paulo, 1982. Tese (Doutorado) Faculdade de Economia e Administração, Universidade de São Paulo.

COSTA, Luís Carlos. Plano Diretor: um personagem a procura de seus autores. São Paulo nos anos 80. 2.ed. São Paulo, 1995. Tese (Doutorado) - Faculdade de Arquitetura e Urbanismo, Universidade de São Paulo.

DANTAS, Jorge de Rezende. Dinâmica da produção imobiliária. São Paulo, Faculdade de Arquitetura e Urbanismo da Universidade de São Paulo/CESAD, 1993.

DERTÔNIO, Hilário. O bairro do Bom Retiro. São Paulo, Prefeitura do Município de São Paulo, 1971. (Série História dos bairros de São Paulo, v.9).

DOREA, Agusta Garcia Rocha. Aclimação. São Paulo, Prefeitura do Município de São Paulo, 1982. (Série História dos bairros de São Paulo, v.19).

EMPRESA BRASILEIRA DE ESTUDOS DE PATRIMÔNIO S/C LTDA. Informativo Imobiliário Embraesp- Relatório Anual 2000. O sistema de financiamento nos últimos 3 anos. São Paulo, EMBRAESP, 2001 p.13)

EMPRESA METROPOLITANA DE PLANEJAMENTO DA GRANDE SÃO PAULO. Diagnóstico 75. São Paulo, s.ed., 1976. 
. Plano metropolitano da Grande São Paulo 1993/2010:

proposta. São Paulo, Empresa Metropolitana de Planejamento da Grande São Paulo, 1994.

. Sumário de dados da Grande São Paulo 1988. São Paulo, Empresa Metropolitana de Planejamento da Grande São Paulo, 1989.

Sumário de dados da Grande São Paulo 1994. São Paulo, Empresa Metropolitana de Planejamento da Grande São Paulo, 1994.

Reconstituição da memória estatística da Grande São

Paulo. São Paulo, Empresa Metropolitana de Planejamento da Grande São Paulo, 1981. 2v.

FELDMAN, Sarah. Planejamento e zoneamento em São Paulo (1947-1972). São Paulo, 1996. Tese (Doutorado) - Faculdade de Arquitetura e Urbanismo, Universidade de São Paulo.

\section{Segregações espaciais urbanas. A territorialização da}

prostituição feminina em São Paulo. São Paulo, 1989. Dissertação (Mestrado) - Faculdade de Arquitetura e Urbanismo, Universidade de São Paulo.

FERREIRA, Miguel Ângelo Barros. O nobre e antigo bairro da Sé. São Paulo, Prefeitura do Município de São Paulo, 1971. (Série História dos bairros de São Paulo, v.10)

FERREIRA, Tito Lívio. A expectativa do paulistano era e é de otimismo. In: EMPRESA METROPOLITANA DE PLANEJAMENTO DA GRANDE SÃO PAULO. Reconstituição da memória estatística da Grande São Paulo. São Paulo, Empresa Metropolitana de Planejamento da Grande São Paulo, 1981. v.2. p.129.

História de São Paulo. São Paulo, Biblos., 1968. v.1. GAMES, John S. Iniciação simples à economia. Rio de Janeiro, Editora Fundo de Cultura, 1952.

GROSTEIN, Marta Dora. A reconstrução permanente. In: CENTRO XXI ENTRE HISTÓRIA E PROJETO. São Paulo, Associação Viva o Centro, 1994. Anais. p.6.

GUEDES, Liliana Marsicano, SÓCRATES, Jodete Rios, TANAKA, Marta Maria Soban. Localização residencial em São Paulo. Sinopses, n.8, p.89, dez.1985.

GUIMARÃES, Laís de Barros. Luz. São Paulo, Prefeitura do Município de São Paulo, 1977. (Série História dos bairros de São Paulo, v.12)

Liberdade. São Paulo, Prefeitura do Município de São Paulo, 
1979. (Série História dos bairros de São Paulo, v.16)

HOMEM, Maria Cecília Naclério. Higienópolis: grandeza e decadência de um bairro paulistano. São Paulo, Prefeitura do Município de São Paulo, 1980. (Série História dos bairros de São Paulo, v.17)

INSTITUTO BRASILEIRO DE GEOGRAFIA E ESTATÍSTICA. Anuário estatístico do Brasil 1994. Rio de Janeiro, Instituo Brasileiro de Geografia e Estatística, 1995.

Anuário Estatístico do Brasil 1970. Rio de Janeiro, Instituo Brasileiro de Geografia e Estatística, 1971.

Censo demográfico do Estado de São Paulo 1991. Rio de Janeiro, Instituo Brasileiro de Geografia e Estatística, 1992.

Sinopse preliminar do Censo 2000. Rio de Janeiro, Instituo Brasileiro de Geografia e Estatística, 2001.

Censo demográfico do Estado de São Paulo 1970. Rio de Janeiro, Instituo Brasileiro de Geografia e Estatística, 1971.

Censo demográfico do Estado de São Paulo 1980. Rio de Janeiro, Instituo Brasileiro de Geografia e Estatística, 1981.

INSTITUTO CULTURAL ITAÚ. Praça do Patriarca/Viaduto do Chá/Praça Ramos de Azevedo. São Paulo, Instituto Cultural Itaú, 1992. (Série Cadernos Cidade de São Paulo, v.1)

Pátio do Colégio. São Paulo, Instituto Cultural Itaú, 1994. (Série Cadernos Cidade de São Paulo, v.2)

Largo de São Bento/Viaduto Santa Ifigênia/Largo Santa

Ifigênia. São Paulo, Instituto Cultural Itaú, 1994. (Série Cadernos Cidade de São Paulo, v.3)

Cadernos Cidade de São Paulo, v.4)

Praça da Sé. São Paulo, Instituto Cultural Itaú, 1994. (Série Largo São Francisco. São Paulo, Instituto Cultural Itaú, 1994. (Série Cadernos Cidade de São Paulo, v.5)

Largo da Memória. São Paulo, Instituto Cultural Itaú, 1994. (Série Cadernos Cidade de São Paulo, v.6)

Avenida Paulista. São Paulo, Instituto Cultural Itaú, 1994.

(Série Cadernos Cidade de São Paulo, v.8)

Região da Luz. São Paulo, Instituto Cultural Itaú, 1994. 
(Série Cadernos Cidade de São Paulo, v.9)

. Estádios. São Paulo, Instituto Cultural Itaú, 1994. (Série Cadernos Cidade de São Paulo, v.10)

Região Tiradentes. São Paulo, Instituto Cultural Itaú, 1994. (Série Cadernos Cidade de São Paulo, v.11)

Bairro dos Campos Elísios. São Paulo, Instituto Cultural Itaú, 1995. (Série Cadernos Cidade de São Paulo, v.12)

Praça da República. São Paulo, Instituto Cultural Itaú, 1995. (Série Cadernos Cidade de São Paulo, v.13)

JORGE, Alcina Ferreira. Bairro do Jardim da Saúde. São Paulo, Prefeitura do Município de São Paulo, 1981. (Série História dos bairros de São Paulo, v.5)

JORGE, Clóvis de Athayde. Consolação: uma reportagem histórica. São Paulo, Prefeitura do Município de São Paulo, s.d. (Série História dos bairros de São Paulo, v.22)

Luz: notícias e reflexões. São Paulo, Prefeitura do Município de São Paulo, 1988. (Série História dos bairros de São Paulo, v.27)

Santa Ifigênia. São Paulo, Prefeitura do Município de São Paulo, 1999. (Série História dos bairros de São Paulo)

LANGENBUCH, Juergen Richard. A estruturação da Grande São Paulo: estudo de geografia urbana. Rio de Janeiro, Instituto Brasileiro de Geografia e Estatística, 1971.

LEFEVRE, José Eduardo de Assis. Transporte coletivo como agente transformador da estruturação do centro da cidade de São Paulo. São Paulo, 1985. Dissertação (Mestrado) - Faculdade de Arquitetura e Urbanismo, Universidade de São Paulo.

LEMOS, Carlos A. Cerqueira. Revalorização dos centros das metrópoles. Urbs, p.32, fev. 1998.

LOBO JUNIOR, Manoel. Vila Leopoldina: como te viram e como te vêem. São Paulo, s.ed., 1986.

LOPES, Helena de Queiroz Ferreira; VILHENA, Vera Lúcia. Itaim-Bibi. São Paulo, Prefeitura do Município de São Paulo, 1988. (Série História dos bairros de São Paulo, v.26)

LUCENA, Maria Margarida Cavalcanti. Avenida Paulista - imagens da metrópole. São Paulo, EDUC, 1996. 
MACEDO, Sílvio Soares. Higienópolis e arredores: processo de mutação de paisagem urbana. São Paulo, PINI, 1987. Originalmente Tese (Doutorado) - Faculdade de Arquitetura e Urbanismo, Universidade de São Paulo.

MAPOGRAF. Guia de Zoneamento 1995. São Paulo, Mapograf, 1995.

MAPOGRAF. O guia 1997. São Paulo, Mapograf, 1997.

MARCONDES, Cláudia de Barros. O poder de transformação urbana da legislação de uso e ocupação do solo do Município de São Paulo. São Paulo, 1988. Dissertação (Mestrado) - Escola Politécnica, Universidade de São Paulo.

MARTIN, André. Bairro do Brás e a deterioração urbana. São Paulo, 1984. Dissertação (Mestrado) - Faculdade de Filosofia, Letras e Ciências Humanas, Universidade de São Paulo.

MARTINS, Maria Lúcia Refinnetti. São Paulo, metrópole e isso tudo 19201980. São Paulo, 1980. Dissertação (Mestrado) - Faculdade de Arquitetura e Urbanismo, Universidade de São Paulo.

MARZOLA, Nádia. Bela Vista. São Paulo, Prefeitura do Município de São Paulo, 1979. (Série História dos bairros de São Paulo, v.15)

MASAROLO, Pedro. Bairro da Vila Mariana. São Paulo, Prefeitura do Município de São Paulo, 1971. (Série História dos bairros de São Paulo, v.8)

MASCARÓ, Juan. Custo de infra-estrutura. São Paulo, 1979. Tese (Livre Docência), Faculdade de Arquitetura e Urbanismo, Universidade de São Paulo.

MATTOS, Dirceu Lino de. O parque industrial brasileiro. In: AZEVEDO, Aroldo Edgard de, coord. A cidade de São Paulo: estudos de geografia urbana. São Paulo, Companhia Editora Nacional, 1958. v.3, p.5.

MCCLOSKEY, DONALD N. The economics of choice - neoclassical supply and Demand. IN RAWSKI, Thomas. Economics and the Historian. Berkeley, University of California Press, s.d.

MELLO, Marina Figueira de. Análise da participação feminina no mercado de trabalho no Brasil. São Paulo, 1982. Dissertação (Mestrado) Faculdade de Economia e Administração, Universidade de São Paulo.

MENDES, Renato da Silveira. Os bairros da zona norte e orientais. In: AZEVEDO, Aroldo Edgard de, coord. A cidade de São Paulo: estudos de geografia urbana. São Paulo, Companhia Editora Nacional, 1958. v.3, p.183. 
MENDES, Renato da Silveira. Os bairros da zona sul e os bairros ocidentais. In: AZEVEDO, Aroldo Edgard de, coord. A cidade de São Paulo: estudos de geografia urbana. São Paulo, Companhia Editora Nacional, 1958. v.3, p.257.

METRÔ. Pesquisa OD-1997. São Paulo, METRÔ, 1997.

MEYER, Regina Maria Prósperi. O centro da metrópole como projeto. In: CENTRO XXI ENTRE HISTÓRIA E PROJETO. São Paulo, Associação Viva o Centro, 1994. Anais. p.4.

MEYER, Regina Maria Prósperi. São Paulo centro uma nova abordagem. São Paulo, Associação Viva o Centro, 2000.

MORSE, Richard. Formação histórica de São Paulo. Da comunidade a metrópole. São Paulo, s.ed.,1954.

MÜLLER, Nice L. A área central da cidade. In: AZEVEDO, Aroldo Edgard de, coord. A cidade de São Paulo: estudos de Geografia Urbana. São Paulo, Companhia Editora Nacional, 1958. v.3, p.121.

NEGRI, Barjas. Concentração e desconcentração industrial em São Paulo (1880-1990). Campinas, s.ed., 1996.

OLIVEIRA, Raimunda Maria de. Perdizes: um momento do imenso movimento do mundo. São Paulo, 1995. Dissertação (Mestrado) Faculdade de Filosofia, Letras e Ciências Humanas, Universidade de São Paulo.

OSELLO, Marcos Antônio. Planejamento urbano em São Paulo (18991961). Introdução ao estudo dos planos e realizações. São Paulo, 1983. Tese (Doutorado) - Fundação Getúlio Vargas.

PACHECO, José Aranha de Assis. Perdizes. São Paulo, Prefeitura do Município de São Paulo, 1982. (Série História dos bairros de São Paulo, v.21)

PETRONE, Pasquale. São Paulo no século XX. In: AZEVEDO, Aroldo Edgard de, coord. A cidade de São Paulo: estudos de geografia urbana. São Paulo, Companhia Editora Nacional, 1958. v.2, p.101.

Paulo, EDUSP, 1963.

coord. Pinheiros: aspectos geográficos de um bairro. São

PONCIANO, Levino. As mil faces de São Paulo. São Paulo, Fênix, 1999.

PONTES, José Alfredo O. Vidigal. Francisco Prestes Maia: "o político que não gostava de política". Cidade (Revista do Departamento de Patrimônio Histórico/Secretaria Municipal de Cultura da Prefeitura do Município de São 
Paulo, n.4, p.4, 1996.

PORTO, Antônio Rodrigues. História urbanística da cidade de São Paulo (1554-1988). São Paulo, Carthago\&Forte Editoras Associadas, 1992.

QUADROS, Waldir José. Milagre brasileiro e a expansão da nova classe média. São Paulo, 1991. Tese (Doutorao) - Universidade Estadual de Campinas.

REALE, Ebe. Brás, Pinheiros, Jardins: três bairros, três mundos. São Paulo, Pioneira/EDUSP, 1982.

REIS FILHO, Nestor Goulart. São Paulo e outras cidades: produção social e degradação dos espaços urbanos. São Paulo, HUCITEC, 1994.

ROLNIK, Raquel. São Paulo: crise e mudança. São Paulo, Brasiliense, 1990.

A cidade e a lei. Legislação, política urbana e territórios

na cidade de São Paulo. São Paulo, Studio Nobel/FAPESP, 1997.

SAES, Décio. Classe média e sistema político no Brasil. São Paulo, TA

Queiroz editora Itda, 1985.

SANTOS, Márcio p. O Bom Retiro: uma paisagem paulistana. São Paulo, 2000. Dissertação (Mestrado) - Faculdade de Filosofia, Letras e Ciências Humanas, Universidade de São Paulo.

SANTOS, Milton. Tendências de urbanização brasileira no fim do século XX. In: CARLOS, Ana Fani Alessandri, coord. Os caminhos da reflexão sobre a cidade e o urbano. São Paulo, EDUSP, 1994.

SANTOS, Wanderley. Lapa. São Paulo, Prefeitura do Municipio de São Paulo, 1980. (Série História dos bairros de São Paulo, v.18)

SÃO PAULO, Prefeitura do Município de/Secretaria Municipal de

Planejamento. Plano Diretor do Município de São Paulo 1985/2000. São

Paulo, Prefeitura do Município de São Paulo, 1985.

São Paulo, 1990.

Plano Diretor 1990. São Paulo, Prefeitura do Município de

BDP-92 - Base de dados para planejamento. São Paulo,

Prefeitura do Município de São Paulo, 1992.

Evolução do Uso do solo nos anos 90. São Paulo, Prefeitura do Município de São Paulo, 2000.

Globalização e desenvolvimento urbano. São Paulo,

Prefeitura do Município de São Paulo, 2000. 
. Perfil sócio-econômico do Município de São Paulo. São Paulo, Prefeitura do Município de São Paulo, 2000.

. Geolog - aplicações geográficas. São Paulo, Prefeitura do Município de São Paulo, 2000.

São Paulo em números. São Paulo, Prefeitura do Município de São Paulo, 2000.

SÃO PAULO, Prefeitura do Município de/Secretaria Especial de Reforma Administrativa. O poder em São Paulo: história da administração pública da cidade (1554-1992). São Paulo, Cortez, 1992.

SÃO PAULO, Prefeitura do Município de. Código de obras. São Paulo, Edições Lep Ltda, 1955.

Ltda, 1968.

Código de obras. São Paulo, Livraria Legislação Brasileira

Plano Urbanístico Básico. São Paulo, Prefeitura do

Município de São Paulo, 1969.

SEGATTO, J. coord. Lapa: evolução histórica. São Paulo, Prefeitura do Município de São Paulo, 1988.

SILVA, Raul Andrade. São Paulo nos tempos coloniais. In: AZEVEDO, Aroldo Edgard de, coord. A cidade de São Paulo: estudos de geografia urbana. São Paulo, Companhia Editora Nacional, 1958. v.2, p.5.

SIMONSEN, Roberto. Aspectos da história econômica do café. In: Congresso de História Nacional promovido pelo Instituto Histórico e Geográfico Brasileiro 1938. São Paulo, Instituto Histórico e Geográfico Brasileiro, 1938. Anais.

SINGER, Paul. Desenvolvimento econômico e evolução urbana. São Paulo, s. ed., 1968.

SMOLKA, Martim Oscar. Estruturas intra-urbanas e segregação social no espaço: elementos para uma discussão da cidade na teoria econômica. Rio de Janeiro, ANPEC, 1983.

SÓCRATES, Jodete Rios. Uso do solo em São Paulo. São Paulo, 1983. Dissertação (Mestrado) - Faculdade de Arquitetura e Urbanismo, Universidade de São Paulo.

SOMEKH, Nádia. Cidade vertical e o urbanismo modernizador: São Paulo 1920-1939. São Paulo, 1994. Tese (Doutorado) - Faculdade de Arquitetura e Urbanismo, Universidade de São Paulo. 
Dissertação (Mestrado) - Faculdade de Arquitetura e Urbanismo, Universidade de São Paulo.

A verticalização de São Paulo: um elemento de segregação urbana. Espaço\&Debates, n.21, p.72, 1987.

SOUZA, Maria Adélia Aparecida de. A identidade da metrópole. São Paulo, Hucitec/EDUSP, 1994.

TARALLI, Cibele Haddad. Ambiente construído e legislação: o visível e o imprevisível. São Paulo, 1993. Tese (Doutorado) - Faculdade de Arquitetura e Urbanismo, Universidade de São Paulo.

TOLEDO, Benedito Lima de. Álbum iconográfico da avenida Paulista. São Paulo, Ex-Librix, 1987.

cidades, 1981.

São Paulo: três cidades em um século. São Paulo, Duas

Rumo ao Paraíso: evolução de um bairro. São Paulo, Racional Engenharia, 1990.

TOMINAGA, Yasuko. Memória de um lugar através de suas imagens históricas e da legislação: o Bexiga, a Liberdade e a avenida Paulista. Um estudo de caso. São Paulo, 1993. Dissertação (Mestrado) - Faculdade de Arquitetura e Urbanismo, Universidade de São Paulo.

TORRES, Maria Celestina Teixeira Mendes. Ibirapuera. São Paulo, Prefeitura do Município de São Paulo, 1977. (Série História dos bairros de São Paulo, v.11)

O bairro do Brás. São Paulo. Prefeitura do Município de São Paulo, 1969. (Série História dos bairros de São Paulo, v.1) ULMANN, Edward. A theory of location for cities IN MAYER, Harold, A theory of location for cities. Chicago, The University of Chicago Press, 1959.

VARGAS, Heliana Comin. Localização estratégica ou estratégia da localização. São Paulo, 1993. Tese (Doutorado) - Faculdade de Arquitetura e Urbanismo, Universidade de São Paulo.

VARGAS, Milton. Metodologia da pesquisa tecnológica. Rio de Janeiro, Globo, 1985.

VASCONCELLOS, Marco Antônio S; GARCIA, Manuel. Fundamentos de economia. São Paulo, Ed. Saraiva, 1998.

VILLAÇA, Flávio José Magalhães. A estrutura territorial da metrópole sul brasileira: áreas residenciais e comerciais. São Paulo, 1978. Tese (Doutorado) - Faculdade de Filosofia, Letras e Ciências Humanas, 
Universidade de São Paulo.

Espaço intra-urbano no Brasil. São Paulo, Studio

Nobel/FAPESP/Lincoln Institute, 1998.

WAKISAKA, Tânia. Zoneamento de uso e ocupação do solo e produção do espaço urbano em São Paulo. São Paulo, 1991. Dissertação (mestrado)

- Faculdade de Arquitetura e Urbanismo, Universidade de São Paulo.

ZMITROWICZ, Witold. Funções urbano rurais como condicionantes da implantação do zoneamento na cidade de São Paulo. São Paulo, 1979. Dissertação (Mestrado) - Escola Politécnica, Universidade de São Paulo.

As obras públicas de engenharia e a sua função na

estruturação da cidade de São Paulo. São Paulo, 1985. Tese (Doutorado) Escola Politécnica, Universidade de São Paulo.

\section{Obras públicas de engenharia e a sua função na}

estruturação da cidade de São Paulo. São Paulo, 1986. (Boletim Técnico do Departamento de engenharia de Construção Civil e Urbana 05/86) - Escola Politécnica, Universidade de São Paulo.

A estruturação da cidade pelas rotinas urbanas. São Paulo, 1998. Tese (Livre Docência) - Escola Politécnica, Universidade de São Paulo.

. O sonho e a realidade do "Plano de Avenidas". Cidade (Revista do Departamento de Patrimônio Histórico/Secretaria Municipal de Cultura da Prefeitura do Município de São Paulo, n.4, p.28, set.1996.

Artigos de Jornal

BRANDÃO, Francisco. Tombamento pode preservar Jardim Lusitânia. $\mathbf{0}$ Estado de S. Paulo. São Paulo, 04 de jun. 1999.

CARELLI, Gabriela. Desrespeito ao zoneamento começa a diminuir. $\mathbf{0}$ Estado de S. Paulo, São Paulo, 06 de dez. 1998. - Moradores apelam para tombamento de bairros. O Estado de S. Paulo, São Paulo, 06 de dez. 1998.

CINTRA CAVALCANTE DE ALBUQUERQUE, Marcos. Zoneamento e justiça. Folha de São Paulo, São Paulo, 03 de dez. 1995.

CRUZ, Ana Claudia. Renovação do centro precisa de apoio público. O Estado de S. Paulo, São Paulo, 23 de set. 1999.

. Galpões dãolugar a p'redios na Lapa. O Estado de S. Paulo, São Paulo, 23 de mar. 1997. 
. Moema atrai pessoas de toda a cidade. O Estado de S.

Paulo, São Paulo, 08 de jun. 1999.

GARBIN, Luciana. Tombamento provoca polêmica na região. O Estado de S. Paulo, São Paulo, 14 de Abr. 1999.

- Entidade pede melhorias há 48 anos. O Estado de S. Paulo, São Paulo, 24 de Mar. 1999.

HECK, Marina. Até que enfim. Folha de São Paulo, São Paulo, 19 de jun. 1995.

JELIN, Daniel. Livro conta passado da Vila e resgata personagem do dia a dia. O Estado de S. Paulo, São Paulo, 01 jul. 1998.

LOURES, Wilma. Obra renova ocupação de Pinheiros. O Estado de S. Paulo, São Paulo, 06 de abr. 1997.

MEDEIROS, Jotabê. Arquitetos esperam com ansiedade o projeto final do 'Godzilla' do centro de São Paulo. O Estado de S. Paulo, São Paulo, 03 de jul. 1999.

MORAES, Maurício. Industrias remanescentes enfrentam fim da 'era industrial'. O Estado de S. Paulo, São Paulo, 15 de jun. 1999.

Famílias tradicionais viraram berço do rock. O Estado de S.

Paulo, São Paulo, 13 de jout. 1999.

- Um novo cartão postal para a Água Branca. O Estado de S.

Paulo, São Paulo, 19 de jan. 2000.

NAKAYAMA, Daniela. Comunidades atuam em conjunto. O Estado de S.

Paulo, São Paulo, 09 de abr. 1999.

- Butiques de rua ganham status internacional. O Estado de

S. Paulo, São Paulo, 08 de jan. 1999.

O ESTADO DE S. PAULO. Tombamento preserva verde e arquitetura. 0

Estado de S. Paulo, São Paulo, 09 de abr. 1999.

Região central enfrenta desafios pela revitalização.

Estado de S. Paulo, São Paulo, 13 de jun. 1999.

A ‘conquista do espaço' em São Paulo é uma história cercada de controvérsias. São Paulo, O Estado de S. Paulo, São Paulo, 03 de jul. 1999.

PASQUALIN, Roberto. Reengenharia no direito da cidade. O Estado de S. 
Paulo, São Paulo, 28 de dez. 1995.

PEREIRA, Paula. Abuso ao zoneamento abre guerra entre vizinhos. 0 Estado de S. Paulo, São Paulo, 19 de jul. 1999. . Moradores propõe reduzir altura de prédio. O Estado de S. Paulo, São Paulo, 11 de dez. 1998.

PINHEIRO, Liliana. Melhores empregos ficam em São Paulo. O Estado de S. Paulo, São Paulo, 23 de ago. 1999.

PITTA, luri. Correios mudam perfil da Vila Leopoldina. O Estado de S. Paulo, São Paulo, 19 de abr. 2000.

COLEÇÃO DE MAPAS:

FACULDADE DE ARQUITETURA E URBANISMO DA UNIVERSIDADE DE SÃO PAULO/BIBLIOTECA:

SÃO PAULO. Prefeitura do Município. Planta da cidade de São Paulo. São Paulo, 1922. Escala gráfica.

SÃO PAULO. Prefeitura do Município. Planta da cidade de São Paulo mostrando todos os arrabaldes e terrenos arruados. São Paulo, 1924. Escala: 1:26.000.

SÃO PAULO. Prefeitura do Município/SARA BRASIL. Mappa Topographico do Município de São Paulo. São Paulo, 1930. Escala 1:5.000

SÃO PAULO. Prefeitura do Município. Município de São Paulo. São Paulo, 1954. Escala 1:2.000.

SÃO PAULO. Governo do Estado de./GEGRAN. Grande São Paulo. São Paulo, 1972/1974. Escala 1:2.000. 


\section{ANEXOS}

\section{1 - PERÍMETROS DA LEGISLAÇÃO}

Lista de leis e decretos com seus respectivos perímetros e exceções do período anterior a 1972 1922-1951 Legislação estritamente residencial com permissão de uso residencial vertical

lei $3571 / 37$

av. Paulista

av. Higienópolis

av. Angélica

av. Pedro I

av. Pompéia

r. Maranhão

lei $3691 / 48$

av. Pompéia (acrescenta trecho)

lei $3845 / 50$

rua Ricardo Daunt

lei 4019/51

al. Ministro Rocha Azevedo

lei $4077 / 51$

r. Lisboa (entre av. Rebouças e r. Artur Azevedo)

lei 4086/51

cruzamento da Al. Barão do Rio Branco e r. Guaianazes com Al. Glette e Nothman

dec $943 / 47$

al. Jaú

1952-1972 Legislação estritamente residencial com permissão de uso residencial vertical

lei $4179 / 52$

r. Grécia

lei $4252 / 52$

r. Acaraú

r. Araquã

r. Avanhandava

lei $4321 / 52$

al. Sarutaiá

lei 4351/53

r. Pamplona (entre r. Itapeva e av. Paulista)

r. dos Ingleses (entre av. Brig. Luís Antônio e r. dos Franceses)

r. Martiniano de Carvalho (entre Pç Amadeu Amaral e rua Pedroso)

r. Santa Madalena (entre av. Brig. Luís Antônio e r. Martiniano de Carvalho) 


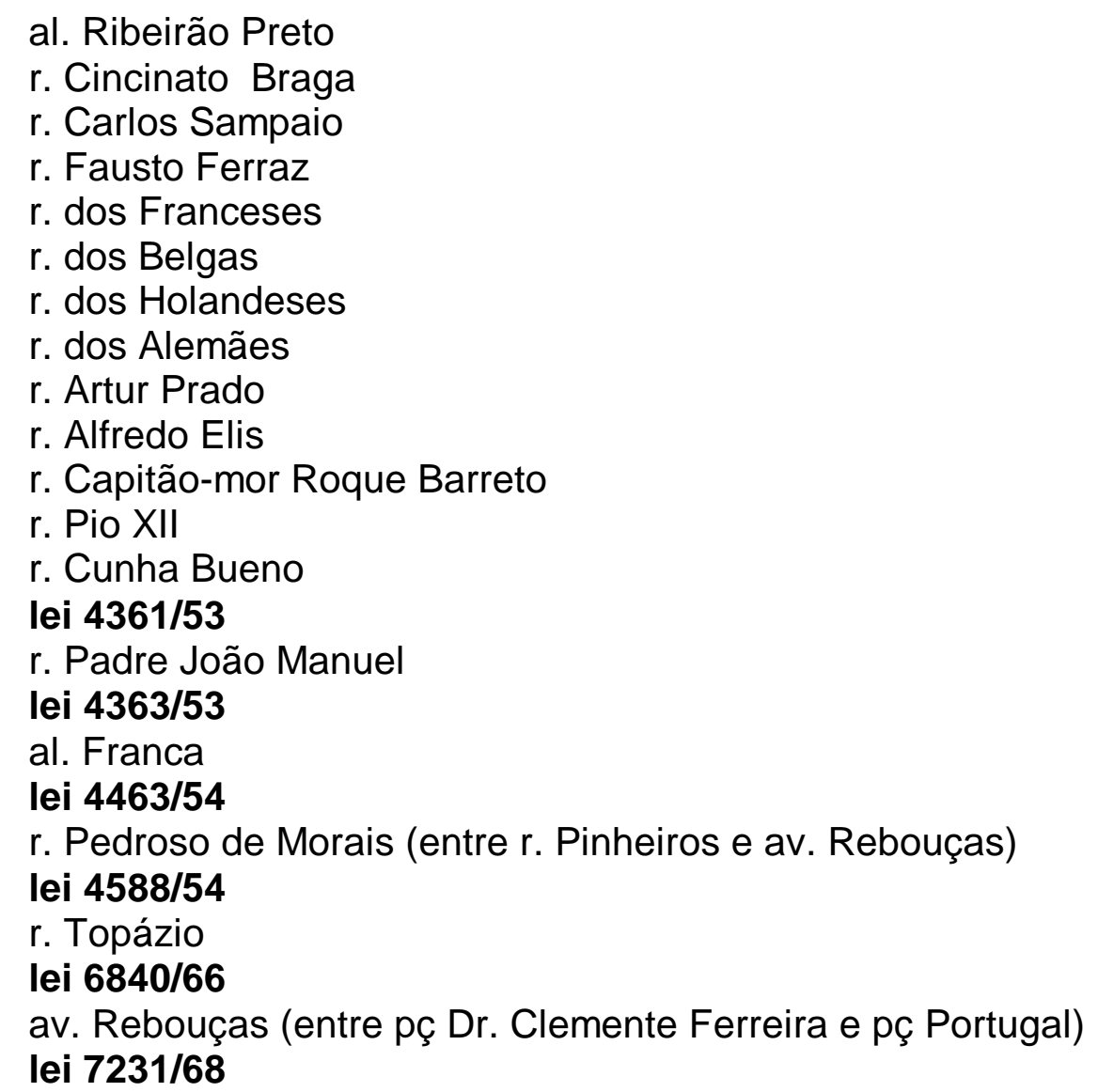

perímetro que se inicia na confluência da av. República do Líbano com a $r$. Afonso Brás, r. Afonso Brás, av. Santo Amaro, av. Antônio Joaquim de Moura Andrade e r. Afonso Brás com av. República do Líbano exceto: av. Santo Amaro (entre r. Afonso Brás e av. Antônio Joaquim de Moura Andrade e r. Afonso Brás (entre a av. Santo Amaro e av. República do Líbano dec 1864/52

r. Monte Alegre

dec 1865/52

Pç Vilaboim

dec 1866/52

r. Prudente Correia

r. Cap. João Ferreira da Rosa

obs: tolera núcleo comerciais existentes, proibe novos

dec 1867/52

r. Ministro Godói

dec 2044/52

r. Venceslau Flexa

r. Cesário Coimbra

r. Maria Carolina

obs: tolera núcleo comerciais existentes, proibe novos

dec 2476/54

r. Frei Caneca (entre av. Paulista e r. Matias Aires)

r. Haddock Lobo (entre av. Paulista e r. Matias Aires)

r. Bela Cintra (entre av. Paulista e r. Matias Aires)

r. Luís Coelho (entre r. Frei Caneca e r. Bela Cintra) 
r. Antônio Carlos (entre r. Frei Caneca e r. Bela Cintra)

r. Matias Aires (entre r. Frei Caneca e r. Bela Cintra)

obs: exclui lotes de esquina com r. Augusta até distância de 40 metros do

alinhamento

dec 2487/54

r. Piauí (entre r. da Consolação e r. Rio de Janeiro)

dec 2561/54

r. Oscar Freire (entre av. Rebouças e r. Teodoro Sampaio)

dec 2573/54

r. Taiarana

r. Visconde de Ouro Preto

av. Indianópolis (entre av. Conselheiro rodrigues Alves e r. Uberaba)

av. Iraci (entre r. Uberaba e av. Jabaquara)

dec 2680/54

al. Barros (entre av. Angélica e r. Conselheiro Brotero)

dec 2722/54

perímetro entre r. Nilo com r. Pires da Mota, r. Paes de Andrade, r. Muniz de

Souza, r. Maracaí, r. Paulo Orozimbo, r. Coronel Diogo Batista Caetano, av.

Fundo de Vale, r. Brígida, r. Avelina, r. Bartolomeu de Gusmão, r. Carlos Petit,

r. Gregório Serrão, r. 1, r. Vergueiro, r. Nicolau de Souza Queiróz, r. Apeninos,

r. Corria Dias, r. Chuí, r. Nilo com r. Pires da Mota

obs: exclui lotes com frente para r. Vergueiro, r. José Getúlio, r. Muniz de

Souza (entre Pais de Andrade e Maracaí), r.1 (entre r. Vergueiro e Gregório

Serrão), r. Machado de Assis (entre r. Gregório Serrão e José do Patrocínio)

dec $6637 / 66$

r. Itacema

1922-1951 Legislação estritamente residencial

lei $3846 / 50$

r. Afonso Milliet

r. Juventina Santana

lei $3901 / 50$

r. Curitiba (entre r. do Livramento e projetada av. Anhangabaú)

ato $127 / 31$

Jardim Europa (todas as ruas)

perímetro entre r. Estados Unidos, r. Brig. Luís Antônio, r. Groenlândia, r. Dona Hipólita até r. Estados Unidos

ato $663 / 34$

Jardim Europa (todas as ruas)

perímetro entre r. Estados Unidos, r. Brig. Luís Antônio, r. Groenlândia, r. Dona Hipólita até r. Estados Unidos

ato $791 / 35$

perímetro entre Auto Estrada de Santo Amaro, r. França Pinto, av. Conselheiro Rodrigues Alves, r. Amâncio de Carvalho, r. Pelotas, r. Curitiba e seu

prolongamento até av. Brig. Luís Antônio

ato $848 / 35$

avenida Rebouças

ato $1120 / 36$

todas as ruas do Jardim Europa

ato $1294 / 37$ 
r. São Vicente de Paula

ato $1300 / 37$

r. Marquês de Paranaguá

ato $1357 / 38$

av. Brasil (prolongamento da av. Brasil entre cruzamento com a R. França Pinto e r. Domingos de Morais pela r. Sena Madureira)

ato $1496 / 38$

av. Nove de Julho (entre Al. Jaú e vias que circundam o jardim a ser feito sobre o túnel)

dec $39 / 40$

r. Caio Prado

r. Alagoas

dec 223/41

r. Bahia

dec 260/41

r. Dr. Fabrício Vampré

r. Coronel Artur de Godói

r. Haiti

dec 424/43

av. Brig. Luís Antônio (entre r. Groenlândia e r. Anajás)

dec 458/43

av. Brig. Luís Antônio (trecho final e extensão entre ruas Groenlândia e Fernando Borges)

praça de confluência das ruas Anajás e Joaquim Floriano

obs: exclui lotes na esquina da referida praça com av. Brig. Luís Antônio)

dec 487/44

r. Caconde

r. Guarará

al. Campinas

dec 559/44

r. Dona Veridiana

dec 592/45

r. Itapicuru (entre r. Traipu e r. Franco da Rocha)

dec 593/45

r. Oscar Freire (entre r. Augusta e Al. Casa Branca)

dec 613/45

r. Minas Gerais

dec 666/45

r. São Carlos do Pinhal

al. Santos

dec 668/45

al. Lorena

r. Topázio

dec 831/46

al. Eugênio de Lima

al. Casa Branca (entre al. Jaú e r. Estados Unidos)

r. Atlântica (entre r. Groenlândia e r. Quilombo)

r. Dona Hipólita (entre r. Groenlândia e r. Quilombo)

r. Quilombo 
r. Juquiá

r. Itapirapoã

r. Jacupiranga

r. Barão de Capanema

r. Itambé

dec 896/46

r. Luís Coelho

r. Tupi (entre r. Goitacás e av. Pacaembú)

dec 920/46

r. Turiaçu (entre r. Cardoso de Almeida e r. Traipú)

dec lei $99 / 41$

perímetro entre r. Estados Unidos, r. Chile e seu prolongamento até r.

Groenlândia, r. Groenlândia e Atlântica

av. Brasil (entre av. Rebouças e r. Atlantica e entre r. Chile e r. Manuel da

Nóbrega)

1952-1972 Legislação estritamente residencial

lei $4237 / 52$

r. Alagoas (entre r. Paulo Eiró e r. Itápolis)

r. Itápolis (entre r. Alagoas e r. Itatiara)

r. Paulo Eiró

r. Itatiara

lei $4300 / 52$

r. Irlanda

r. Antônio José da Silva

r. Salvador de Mendonça

pç Morungaba

pç Buritama

lei $4451 / 54$

avenida Cidade Jardim (entre pç Vaticano e pç Cidade Jardim)

obs: exclui dois núcleos comerciais na r. Benedito Calixto com pç Vaticano e na av. Cidade jardim com r. Benedito Calixto)

lei 4651/55

r. Alagoas (entre r. Paulo Eiró e r. Itápolis)

lei $4958 / 56$

av. Sumaré

lei $5466 / 58$

perímetro entre cruzamento da Estrada de Santo Amaro com av. Periquito, $r$. Periquito, r. Araguaci, av. Rouxinol, r. Pintassilgo, av. Miruna, r. Inambu, av. dos Eucaliptos, Estrada de Santo Amaro, r. Alvorada, r. Marcílio Dias, r. Quatá e Estrada de Santo Amaro até cruzamento da Estrada de Santo Amaro com av. Periquito obs: exclui av. Santo Amaro entre córrego Uberabinha e av. dos Eucaliptos (lado esquerdo) e rua Alvorada (lado direito)

lei 5959/62

r. Rodrigues Guião

lei 6060/62

r. Áurea (entre r. Rio Grande e av. Conselheiro Rodrigues Alves)

r. Dona Alice de Castro (entre r. Rio Grande e av. Conselheiro Rodrigues Alves) 
r. Nakaia (entre r. Rio Grande e av. Conselheiro Rodrigues Alves)

r. Morgado Mateus (entre r. Rio Grande e av. Conselheiro Rodrigues Alves)

r. Joaquim Távora (entre r. Rio Grande e av. Conselheiro Rodrigues Alves)

lei $6087 / 62$

av. Teresa Cristina (entre av. D. Pedro e av. Água Funda)

lei $6111 / 62$

av. Nove de Julho (prolongamento desde confluência de r. Marina Cintra e Holanda até pç Coração de Maria

lei 6245/63

Pç Armando Sales de Oliveira

lei 6579/64

perímetro entre r. Dr. Mário Ferraz, av. Cidade Jardim, av. Marginal, r.

Tucumã, r. Dr. Mário Ferraz

obs: exclui av. Marginal

lei $6656 / 65$

avenida ao longo do Córrego do Sapateiro (entre av. República do Líbano e rua Ramos Batista)

lei $6804 / 65$

r. Irací

r. Jacarezinho

r. Campo Verde

r. Ibianópolis

Pç Coronel Pires de Andrade

al. Gabriel Monteiro da Silva (entre r. Iguatemí e av. Nações Unidas)

lei 6840/66

av. República do Líbano (entre av. Brig. Luís Antônio e av. IV Centenário)

av. IV Centenário (entre av. República do Líbano e Brasil)

av. Rebouças (entre Pç Portugal e av. Nações Unidas)

r. Curitiba

perímetro iniciado na confluência da Av. Nove de Julho com R. Estados Unidos, r. Estados Unidos, av. Brig. Luís Antônio, r. Jundiaí, r. Manuel de Nóbrega, av. República do Líbano, av. Brig. Luís Antônio, r. Groenlândia, av. Nove de Julho, r. Estados Unidos

perímetro iniciado na confluência da r. Groenlândia com av. Nove de Julho, av. Nove de Julho, r. Rússia, r. Itália, r. Áustria, r. Polônia, r. Groenlândia, av. Nove de Julho

perímetro iniciado na confluência da r. Estados Unidos com r. Atlântica, $r$. Atlântica, r. Groenlândia, al. Gabriel Monteiro da Silva, r. Estados Unidos, r. Atlântica obs: exceto av. Brig. Luís Antônio (entre r. Jundiaí e Rep do Líbano), lado ímpar da r. Manoel de Nóbrega (entre r. Jundiaí e av. República do Líbano), lado par da av. Nove de Julho (entre r. Groenlândia e r. Holanda) e lado ímpar da av. Nove de Julho (entre r. Groenlândia e r. João Cachoeira)

lei 6858/66

r. Dinamarca (prolongamento)

lei 7096/67

avenida de fundo de vale

via de ligação entre a avenida de fundo de vale e a av. Lins de Vasconcelos

lei 7134/68 
perímetro inicado na confluência da av. República do Líbano e al. Jauaperi, al. Jauaperi, al. Jaúnas, r. Colibri, r. Canário, rua projetada ao longo do córrego Uberaba, r. Diogo Jácome, r. Afonso Brás, av. República do Líbano com al. Jauaperi obs: exceto r. e avenida ao longo do córrego Uberaba (entre r. Canário e r. Diogo Jácome), r. Diogo Jácome (entre av. córrego Uberaba e r. Afonso Brás), r. Afonso Brás (entre Diogo Jácome e Euclides Parente Ramos)

\section{dec $1631 / 52$}

r. Paulo Eiró

r. das Mangabeiras

avenida Aclimação

dec 2575/54

avenida Aclimação

dec 2578/54

perímetro entre Estrada de Santo Amaro, av. dos Eucaliptos, av. Dr. Rodrigues Alves e córrego da Traição

\section{dec 2654/54}

perímetro delimitado pela r. Estados Unidos, av. Rebouças, r. Iguatemi, av. Cidade Jardim, prolongamento da av. Nove de Julho, r. Anajás, pç Gastão Liberal, Estrada de Santo Amaro, r. Afonso Bráz, av. República do Líbano, r. Manuel da Nóbrega, r. Jundiaí, av. Brig. Luís Antônio, r. Groenlândia, r. Atlântica obs: exceto r. Iguatemi, av. Cidade Jardim, r. Suzano, r. Maestro Elias Lobo (entre r. Groenlândia e r. Anajás), pç Gastão Liberal, estrada de Santo Amaro, r. Afonso Brás, r. Jundiaí, r. Padre Manoel Chaves, r. Capitão Padilha

\section{dec 2747/54}

perímetro delimitado por av. Dr. Arnaldo, viela de ligação da av. Dr. Arnaldo com Estrada do Araçá, Estrada do Araçá, r. Jaciporã, r. Votuporanga, r. Guaçu, pç Redenção da Serra, r. Duartina, r. Arealva, Pç Borborema, viela Adutora de Cotia, av. Dr. Arnaldo, Av. Afonso Bovero, Limite Norte do arruamento Sumaré, av. Sumaré, r. Atalaia, r. Itobi, r. Cardoso de Almeida, r. Tácito de Almeida, r. Cardoso de Almeida e av. Dr. Arnaldo obs: exceto perímetro:av. Dr. Arnaldo, av. Alfonso Bovero, r. Piracicaba e r. Catalão

\section{dec 2783/55}

perímetro que se inicia no cruzamento da Estrada de Santo Amaro com a av. Periquito, av. Periquito, r. Araguari, av. Rouxinol, r. Pintassilgo, av. Miruna, r. Inambu, av. dos Eucaliptos, Estrada de Santo Amaro, r. Alvorada, r. Marcilio Dias, r. Guatá e Estrada de Santo Amaro obs: exceto Estrada de Santo amaro (entre córrego Uberaba e Córrego da Traição)

\section{dec 2811/55}

prolongamento da avenida Brasil (entre os cruzamentos com r. França Pinto e r. Domingos de Morais pela Sena Madureira)

\section{dec 3379/56}

perímetro que se inicia na confluência da avenida Santo Amaro com r. Alvorada, r. Alvorada, r. Elvira Ferraz, r. Ramos Batista, r. Mário de Castro, travessa dos Garimpeiros, r. do Pôrto, r. Lopes Neto, av. Imperial, r. Salvador Cardoso, Tabapuã, r. Dr. Melo Ferraz, av. Cidade Jardim, av. Nove de Julho 
(prolongamento), av. Anajás, Pç dom Gastão Liberal, av. Santo Amaro até confluência de av. Santo Amaro com r. Alvorada

observação: legislação não é válida para zona delimitada pelas ruas Dr.

Osvaldo de Souza Aranha, Clodomiro Amazonas, Joaquim Floriano, Iguatemi, Pedroso Alvarenga, Dr. Renato Paes de Barros e para as ruas: das Fiandeiras, Joaquim Floriano, Iguatemi, Clodomiro Amazonas, Tabapuã (entre r. Salvador Cardoso e Dr. Renato Paes de Barros, Pç dom Gastão Liberal e av. Santo Amaro

\section{dec 3409/56}

perímetro que se inicia na confluência da av Padre Pereira de Andrade e av. Diógenes Ribeiro de Lima, av. Diógenes Ribeiro de LIma, av. Jaguaré, pç Apecatu, av. Fonseca Rodrigues, av. Padre Pereira de Andrade, av. Diógenes Ribeiro de Lima

obs: exceto av. Prof. Fonseca Rodrigues e núcleos comerciais em alguns lotes especificados

dec 3093/56

r. Frei Eusébio da Soledade

r. Manoel de Paiva

r. Conceição Veloso

dec 3104/56

r. Lucílio de Albuquerque

dec 3239/56

r. Irlandino Sandoval

$\operatorname{dec} 3358 / 56$

perímetro delimitado por r. Anastácio com r. Barão de Jundiaí, r. Barão de Jundiaí, r. Marcílio Dias, r. Guararapes, r. Corrientes, r. Sacadura Cabral, r. Mercedes, r. Diogo Ortiz, r. Tordesilhas, r. João Tibiriçá, r. Belmonte, r. Conde de Porto Alegre, r. Montevidéu, r. D, r. Passo da Pátria, av. Diógenes Ribeiro de Lima, r. Princesa Leopoldina, r. Visconde de Indaiatuba, r. Caativa, r. Lapa Pinheiros, r. Pio XI, r. Anastácio

r. Taquarembó (entre r. Passo da Pátria e $70 \mathrm{mts}$ além)

r. Dr. José Elias (entre r. Visconde de Indaiatuba e $140 \mathrm{mts}$ além)

r. Campo Grande (entre r. Passo da Pátria e 295 mts além)

obs: alguns lotes específicos foram excluídos e destinados ao

comércio/serviços

dec 3359/56

perímetro delimitado por r. Claúdio Rossi, r. Sebastião de Souto, r. Pêro Correia, r. Colônia da Glória, r. Claúdio Rossi

dec 3418/56

perímetro iniciado na confluência da r. Alves Guimarães e av. Heitor Penteado, r. M, r. Abegoaria, r. Simpatia, r. H, r. dos Artistas, r. João Moura, r. Amália de Noronha, r. Cristiano viana, r. E, r. Alves Guimarães até av. Heitor Penteado obs: exclui quaras formada por av. Heitor Penteado, Cristiano viana, r. E e r. Alves Guimarães

\section{dec 5361/62}

av. Nove de Julho (prolongamento desde a r. Marina Cintra e r. Holanda até a praça formada pelo entroncamento das r. João Cachoeira e r. Rússia

dec 5552/63

perímetro que se inicia na confluência da R. Nilo com r. Pires da Mota, r. Pires 
da Mota, r. paes de andrade, r. Muniz de Souza, r. Maracaí, r. Paulo Orozimbo, r. Coronel Diogo, r. Batista Caetano, r. Coronel Diogo, avenida de fundo de vale ao longo do córrego Jurubatuba, r. da União, r. Dona Brígida, r. Dona Avelina, r. Bartolomeu de Gusmão, r. Carlos Petit, r. Gregório Serrão, r. Dr. José de Queirós Aranha, r. Vergueiro, r. Dr. Nicolau de Souza Queiroz, r. dos Apeninos, r. Correia Dias, r. Chuí, r. Nilo até r. Pires da Mota obs: exclui: r. Vergueiro, r. dos Apeninos (entre r. Dr. Nicolau de Souza Queiróz e r. Correia Dias), r. Correia Dias (entre r. dos Apeninos e r. Chuí), r. Pires da Mota (entre r. Nilo e r. Pais de Andrade), r. José Getúlio (entre r. Pires da Mota e av. Aclimação), r. Muniz de Souza (entre r. Pais de andrade e r. Maracaí), r. Machado de Assis (entre r. Gregório Serrão e av. Fundo de Vale ao longo do córrego Jurubatuba), r. Dr. José de Queiróz Aranha (entre r. Vergueiro e Gregório Serrão), r. Batista Capelos

\section{dec 6635/66}

r. Gironda (entre av. São Gabriel e r. Henrique Martins)

\section{dec $7445 / 68$}

r. 1 (trecho entre r. Ibiapinópolis e r.2)

\section{Perímetros da primeira lei de zoneamento (lei 7805/72)}

z1-003 comça na confluência da r. Brigadeiro Gavião Peixoto com a r. Dom João V, segue pela r. Dom João V, r. Duarte da Costa, r. Pio XI, r. Piraí, r. Suarruí, r. Araçatuba, travessa1, r. Luíz César Pannain, r. Pontaporã, r. Cerro Corá, pç Silvestre Rabelo, r. pepiguari, r. Bairi, r. Cerro Corá, r. Pio XI, r. Visconde de Indaiatuba, rua Princeza (sic) Leopoldina, av. Diógenes Ribeiro de Lima, r. Passo da Pátria, r. Campo Grande, r. Lauro Muller, r. Schilling, r. Tebicuari, r. Cordilheiras, pç Aquidaban, r. Porteiro Peres, r. Passo da Pátria, r. Jataí, r. Marquês de Paraná, r. Aliança Liberal, r. Montevidéo, r. Conde de Porto Alegre, r. Belmonte, r. Tordesilhas, r. Diogo Ortiz, r. Mercedes, r. Cuevas, r. Corrientes, r. Guararapes, r. Marcílio Dias, r. Brigadeiro Gavião Peixoto até o ponto inicial z1-004 Começa na confluência da r. Bento de Abreu com a r. Aurélia, segue pela r. Aurélia, r. Sepetiba, r. Ajuricaba, r. Cerro Corá, r. Paumari, r. Jaricunas, r. J. A. Castelo Branco, pç Claudino Cézar, r. Bento de Abreu até o ponto inicial z1-005

Começa na confluência da avenida Queiróz filho com a avenida Padre Pereira de andrade, segue pela avenida Padre Pereira de Andrade, r. Pedralva, avenida Professor Fonseca Rodrigues, av. Queiróz filho até o ponto inicial z1-006

Coneça na confluência da r. Nova York com a r. Cayowaa, segue pela r. Cayowaa, r. Doutor Paulo Vieira, r. Aimberê, r. Paracué, r. Cabo Eduardo Alegre, r. Herculano, r. Cayowaa, r. Paracué, r. Paris, viela 1, r. Herculano, pç Nossa Senhora do Carmo, r. Salto Grande, r. Doutor Paulo Vieira, r. André Casado, r. Nova York, r. Saramenha, r. Capital Federal, r. André Casado, r. Nova York, r. Salto Grande, r. Doutor Paulo Vieira, r. Paris, r. Nova York até o ponto inicial

z1-007

Começa na confluência da r. Traipu, com a r. Francisco Estácio fortes, segue pela r. Francisco Estácio Fortes, av. Pacaembú, r. Doutor Veiga Filho, r. Tupi, travessa1, r. Engenheiro Edgar Egídio de Souza, r. Itatiara, r. Armando Penteado, r. Alagoas, r. Ceará, r. Bahia, pç. Humberto de Campos, r. Minas 
Gerais, pç Expedicionários do Brasil, r. Itápolis, r. Sorocaba, av. Doutor Arnaldo, r. Major Natanael, r. Angatuba, r. Itajubá, r. Itatinga, pç Belizário Távaro, r. Monsenhor alberto Pequeno, r. Cardoso de Almeida, av. Doutor Arnaldo, r. Frei Inácio Gau, r. Cristiano Viana, r. Francisco Farel, r. Montezuma, r. Amália de Noronha, r. Ásia, r. Patápio Silva, r. Cipriano Juca, r. Simpatia, segmento 3-4, r. Original, r. Filinto de Almeida, r. Costa Lobo, r. Jericó, r. Rodésia, r. Iperó, r. Paulistania, r. Marinho Falcão, pç Baronesa da Bocaína, r. João Moura, r. Luminárias, r. Prazedes de Abreu, r. Professor Nicolau de Moraes Barros, r. Heitor Penteado, r. Jaciporã, r. Votuporanga, r. Guaçú, pç Redenção da Serra, pç Borborema, r. Doutor Paulo Vieira, r. Coronel Firmo da silva, pç. Domingos Sávio, av. Doutor Arnaldo, r. Catalão, r. Piracicaba, av. Alfonso bovero, r. Plínio de Morais, r. Vargem do Cedro, r. Zaíra, r. Urbanizadora, r 1, pç Irmãos Karman, r. Professor João Arruda, r. Cardoso de Almeida, r. Wanderley, r. José de Freitas Guimarães, r. Caiuby, r. Atibaia, r. Conselheiro Fernando Torres, r. Itapicuru, r. Doutor Alberto Torres, r. Paraguaçu, r. Traipu, r. Turiassu, r. Capitão Messias, r. Doutor Candido Espinheira, r. Traipu até o ponto inicial z1-008 Começa na confluência da r. Ibiraçu, com r. Cerro Corá, segue pela r. Cerro Corá, r. Araiozes, pç B, r. Pereira Leite, pç C, r. Dom Rosalvo, segmento 5-6, r. 1, r. Djalma Coelho, r. Francisco Izoldi, viela 1, segmento 1-2, r. Cristovam de Burgos, r. Paulistania, r. Agissé, segmento 3-4, r. Senador César Lacerda de Vergueiro, viela 1, r. Girassol, r. Rodésia, r. Fradique Coutinho, r. Purpurina, r. Delfina, r. Natingui, r. Ajurapeia, r. Turi, r. Arapi, r. Natingui, r. E, r. das Corujas, r. Um, r. Gomes de Medeiros, r. Alfredo Piragibe, r. Caropá, r. Livi, r. Bernarda Luiz, r. Caminha de Amorim, r. Ibiraçu até o ponto inicial. z1-009

Começa na confluência da r. Cerro Corá com rua 1, segue pela r. 1, r. Maria Leonete da Silva Nóbrega, r. 8, r. Boquim, r. Engenheiro Sá Rocha, r. Japiaçóia, r. Doutor Carlos Norberto de Souza Aranha, r. Dona Elisa de Moraes Mendes, r. Antonio de Gouveia Giudice, r. Miralta, r. Banibas, av. Professor Manoel José Chaves, avenida das Nações Unidas, r. Miralta, r. Bennett, r. Massacá, r. Piacá, r. Castro Delgado, r. General Furtado Nascimento, av. Arruda Botelho, pç. Beethoven, avenida Professor Fonseca Rodrigues, r. Berlioz, av. São Gualter, r. Cerro Corá até o ponto inicial z1-010 Começa na confluência da r. Caropa com rua Livi, segue pela r. Livi, pç Vicentina de Carvalho, r. Coraça, r. Aquiriramun, r. Pasqual Vita, r. Agostinho Bezerra, r. Orânia, r. Desembargador Ferreira França, r. dos Macunis, r. Natingui, r. dos Jupuás, r. dos Tamanás, r. dos Moras, av. Pedroso de Morais, r. dos Macunis, r. dos Juris, r. Padre Carvalho, r. Vupabussu, av. Professor Frederico Herman Jr, av. das Nações Unidas, r. Professor Moniz, r. Carlos Rath, r. Guerra Junqueiro, av. dos Semaneiros, av. das Nações Unidas, av. Professor Manoel José Chaves, r. Banibas, r. Antonio Gouveia Giudice, r. Dona Elisa de Moraes Mendes, r. Doutor Carlos Norberto de Souza Aranha, r. Victorino de Carvalho, r. Caropa até o ponto inicial z1-011 Começa na confluência da r. de Pinheiros com av. Brigadeiro Faria Lima, segue pela av. Brigadeiro Faria Lima, av. Euzébio Matoso, pç Antonio Sabino, r. Butantã, Lg de Pinheiros, r. Teodoro Sampaio, r. de Pinheiros até o ponto 
inicial

z1-012

Começa na confluência da av. Rebouças com r. Estados Unidos, segue pela r. Estados Unidos, r. José Clemente, r. Doutor João Pinheiro, r. Doutor David Campista, r. Marechal Bitencourt, r. General Mena Barreto, r. Oliveira Dias, r. Primavera, r. Henrique Martins, r. Gironda, r. Groenlândia, r. Maestro Elias Lôbo, av. São Gabriel, av. 9 de Julho, av. Cidade Jardim, r. Gumercindo Saraiva, av. Brigadeiro Faria Lima, av. Rebouças até o ponto inicial. z1-013

Começa na confluência da av. Euzébio Matoso com av. Brigadeiro Faria Lima, segue pela av. Brigadeiro Faria Lima, r. Campo Verde, r. Ceilão, Córrego

Verde, viela 1, r. Cardoso de Melo Neto, r. Ibiapinópolis, al. Gabriel Monteiro da Silva, av. das Nações Unidas, av. Rebouças, r. Ibiapinópolis, av. Euzébio Matoso, até o ponto inicial z1-015

Começa na confluência da r. Claúdio Rossi com a r. Pero Corrêa, segue pela r. Pero Corrêa, r. Colônia da Glória, r. Claúdio Rossi até o ponto inicial z1-016

Começa na confluência da r. Bento de Andrade com av. República do Líbano, segue pela av. República do Líbano, r. Domingos Fernandes, r. Escobar Ortiz, r. João Lourenço, r. Domingos Leme, r. Bastos Pereira, r. Teviot, av. Antonio Joaquim de Moura Andrade, r. Bento de Andrade até o ponto inicial z1-018

Começa na confluência da av. IV Centenário com av. Ibirapuera, segue pela av. ibirapuera, r. das Mangueirs, av. Professor Ascendino Reis, r. Estado de Israel, av. Ibirapuera, r. Prestes João, r. do Gama, av. República do Líbano, al. Jauperi, al. dos Jaúnas, r. Gaivota, r. 2 Córrego (sic), r. Inhampú, r. Inajaroba, r. Euclides Parente Ramos, r. Afonso Brás, av. República do Líbano, av. IV Centenário até o ponto inicial

z1-019

Começa na confluência da av. Professor Ascendino Reis com av. Rubem Berta, segue pela av. Rubem Berta, av. Indianópolis, al. Iraé, Córrego Uberaba ou Paraguai, av. Professor Ascendino Reis até o ponto inicial z1-020 começa na confluência da av. Traição com av. Presidente Hoover, segue pela av. Presidente Hoover, r. Morais Barros, segmento 1-2, r. 1, r. Afonso Bandeira de Melo, segmento 3-4, r. Cristóvão Pereira, r. Vieira de Morais, r. Santa Rita, r. Machado de Assis, r. Zacarias de Goes, r. Rui Barbosa, r. Conde de Porto Alegre, r. Pirassununga, r. Princesa Isabel, avenida da Traição, av. Santo Amaro, av. Portugal, r. Indiana, r. Arandú, r. Furnas, r. Porto Martins, r. Guararapes, av. Nova Independência, r. Maçambara, r. Porto Martins, r. Quintana, r. Guaraiuva, r. Nebraska, r. Ribeiro do Valle, segmento 1-2, r. Cabo Verde, r. Jurema, pç Coronel Fernandes de Lima, r. Inhambú, av. dos Eucaliptos, r. Elias Fausto, av. Cotovia, al. Jauaperi, av. dos Eucaliptos, av. Ibirapuera, av. Traição até o ponto inicial.

Avenidas com trechos não enquadrados em Z1:

r. Barão de Jundiai, r. Soror Angélica, r. Bairi, av. São Gualter, r. Cerro Corá, r. Japiaçóia, av. Professor Manoel José Chaves, r. Passo da Pátria, r. Heitor Penteado, av. Sumaré, r. Fradique Coutinho, av. Brasil, r. Joaquim Antunes, r. Cardoso de Almeida, r. Almir Pereira Magalhães, av. Europa, av. Doutor 
Arnaldo, r. Aurélia, r. Nazaré Paulsita, pç Antônio Sabino, r. Estados Unidos, av. Cidade Jardim, r. Nova Independência, r. Elvira Ferraz, r. Olimpíadas, al. Gabriel Monteiro da Silva, r. Ribeiro do Vale, r. Guaraiuva, r. Princesa Isabel, r. Jauaperi, av. Jurabatuba, av. República do Líbano, av. Conselheiro Rodrigues Alves, r. Assis Brasil, r. Bernardino de Campos, r. São Sebastião, av. Faria Lima, av. Nove de Julho, av. dos Bandeirantes, av. Rebouças, av. Pedroso de Morais, r. Coropés, r. Miguel Isasa,

\section{Perímetros (Z1) da lei de zoneamento em vigor}

\section{lei 11.157/91}

Z1-005

Começa na confluência da av. Queirós Filho com a av. Padre Pereira de Andrade, segue pela av. Padre Pereira de Andrade, r. Ariqueme, r. Pedralva, av. Prof. Fonseca Rodrigues, acesso à av. Queirós filho e av. Queirós Filho até o ponto inicial

Z1-028

Começa na confluência da av. Professor Fonseca Rodrigues com a Praça Beethoven (pelo lado da Quadra 76 do Setor Fiscal 96 da Planta Genérica de Valores, segmento 4-3 (divisa do lote 1 com o espaço livre da quadra 33 do Setor fiscal 96 da Planta genérica de Valores), segmentos 3-2 e 2-1 (divisa do lote 20 com o espaço livre da quadra 75 do Setor 96 da Planta Genérica de Valores), linha de transmissão da Eletropaulo, av. Professor Fonseca Rodrigues até o ponto inicial

\section{lei $9411 / 81$}

Z1-003

Começa na confluência da r. Barão de Jundiaí com a viela sem denominação (cadlog 77.097-3), segue pela viela sem denominação, r. Pio XI, r. Piral, r. Suassui, r. Araçatuba, viela sem denominação (cadlog 72.643-5), r. Luís César Pannaim, r. Ponta Porã, r. Cerro Corá, r. Pio XI, r. Visconde de Indaiatuba, r. Princesa Leopoldina, av. Diógenes Ribeiro de Lima, r. Passo da Pátria, r. Campo Grande, r. Lauro Muller, r. Schilling, r. Passo da Pátria, r. Jataí, r. Aliança Liberal, r. Montevidéu, r. Racine, r. Belmonte, r. Monte Pascoal, viaduto Domingos de Morais, r. João Tibiriçá, r. Tordesilhas, r. Diogo Ortiz, av. Mercedes, r. Cuevas, r. Corrientes, r. Guararapes, r. Marcílio Dias e r. Barão de Jundiaí até o ponto inicial Z1-004

Começa na confluência da r. Bento de Abreu com a r. Aurélia, segue pela r. Aurélia, r. Cerro Corá, r. Paumari, r. jaricunas, r. J. A. Castelo Branco, r. Maria Khiel e r. Bento de Abreu até o ponto inicial z1-007 Começa na confluência da r. Traipú com a r. Paraguaçu, segue pela $r$. Paraguaçu, av. Pacaembú, pç Charles Miller (pelo lado das quadras 64 e 61 do setor fiscal 11 da Planta Genérica de Valores), r. Itatiara, r. Armando Penteado, r. Alagoas, r. Ceará, r. Goiás, r. Bahia, pç Humberto de Campos (pelo lado da Quadra 127 do setor fiscal 11 da Planta Genérica de Valores), r. Novo Horizonte (divisa da quadra 136 com a pç Humberto de Campos e quadra 131 do setor fiscal 11 da Planta Genérica de Valores), r. Minas Gerais, pç Marechal Cordeiro de Farias (pelo lado da quadra 127 do setor fiscal 11 da Planta Genérica de Valores), r. Itápolis, r. Professor Ernest Marcus, av. Dr. Arnaldo, r. Major Natanael, r. Angatuba, r. Itajubá, r. Itatinga, pç Belisário Távora (pelo lado das quadras 141 e 76 do setor fiscal 11 da Planta Genérica 
de Valores), r. Monselhor Alberto Pequeno, r. Cardoso de Almeida, av. Dr. Arnaldo, r. Frei Inácio Gau, r. Heitor Penteado, r. Alves Guimarães, r. Amália de Noronha, r. João Moura, r. Ásia, r. Henrique Schaumann, r. Patapio Silva, r. Cipriano Jucá, r. Simpatia, segmento 1-2 (divisa do lote 23 com o lote 24 da quadra 252 do setor fiscal 81 da Planta Genérica de Valores), segmento 2-3 (divisa dos lotes 74 a 80 com o lote 24 da quadra 252 do setor 81 da Planta Genérica de Valores), r. Original, r. Filinto de Almeida, r. Nova Veneza, r. Iperó, r. Professor Nicolau de Morais Barros, r. Heitor Penteado, r. Jaciporã, r. Votuporanga, r. Guaçú, praça Redenção da Serra (pelo lado da quadra 123 do setor fiscal 12 da Planta Genérica de Valores), r. Duartina, pç Borborema, r. Doutor Paulo Vieira, r. Coronel Firmo da Silva, pç Domingos Sávio (pelo lado da quadra 199 do setor fiscal 12 da Planta Genérica de Valores), av. Dr. Arnaldo, r. Catalão, r. Piracicaba, av. Professor Alfonso Bovero, r. Plínio de Morais, r. Vargem do Cedro, r. Zaíra, r. Urbanizadora, r. José Donatelli, pç Irmãos Karman (pelo lado da Quadra 112 do setor fiscal 11 da Planta Genérica de Valores), r. Pedro Coelho, av. Sumaré, r. professor João Arruda, r. Cardoso de Almeida, r. Vanderlei, r. José de Freitas Guimarães, r. Caiubi, r. Atibaia, r. Conselheiro Fernandes Torres, r. itapicru e r. Traipu ate o ponto inicial Z1-008

Começa na confluência da rua Cerro Corá com a r. Araiózes, segue pela r. Araózes, pç Francois Belanger, r. Pereira Leite, pç Jacques Antoine (pelo lado da Quadra 308 do setor Fiscal 81 da Planta Genérica de Valores), r. Orós, r. Dom Rosalvo, av. das corujas, r. Natingui, r. Pascoal Vita, av. das Corujas, $r$. Juranda, r. Miguel Rodrigues, r. Epeira, r. Livi, r. Bernarda Luiz, r. Caminha de Aamorim, r. Ibiraçu e r. Cerro Corá até o ponto inicial

Z1-009

Começa na confluência da r. Cerro Corá com a r. Aecri, segue pela r. Aecri, r. Taruba, r. Maria Leonete da Silva Nóbrega, pç Eugênio Mota (pelo lado da Quadra 33 do setor fiscal 81 da Planta Genérica de Valores, r. Aldo de Azevedo, r. Boquim, r. Engenheiro Sá Rocha, r. Japiaçóia, r. Doutor Carlos Norberto de Souza Aranha, r. Dona Elisa de Morais Mendes, segmento 1-2 (divisa do lote 2 com o lote 16 da Quadra 186 do setor fiscal 81 da Planta Genérica de Valores), segmento 2-3 (divisa do lote 4 com o lote 16 da Quadra 186 do setor fiscal 81 da Planta Genérica de Valores), avenida São Gualter, segmentos 4-5, 5-6 (divisa do lote 8 com o lote 11 da quadra 185 do setor fiscal 81 da Planta Genérica de Valores), avenida Professor Fonseca Rodrigues, segmento 7-8 (divisa do lote 10 com o lote 20 da Quadra 137 do setor fiscal 82 da Planta Genérica de Valores), segmento 8-9 (divisa do lote 2 com o lote 20 da quadra 137 do setor fiscal 82 da Planta Genérica de Valores), segmento 9-10 (divisa do lote 2 com o lote 13 da quadra 137 do setor fiscal 82 da Planta Genérica de Valores), r. Umburanas, segmento 11-12 (divisa do lote 20 com o lote 28 da quadra 138 do setor fiscal 82 da Planta Genérica de Valores), segmento 12-13 (divisa dos lotes 9, 8, 7, 6, 5 e 4 com o lote 28 da quadra 138 do setor fiscal 82 da Planta Genérica de Valores), segmento 13-14 (divisa do lote 29 com o lote 25 da quadras 138 do setor fiscal 82 da Planta Genérica de Valores), av. Professor Manuel José Chaves, pç Arcipreste Anselmo de Oliveira (pelo lado das quadras 140, 142 e 143 do setor 82 da Planta Genérica de Valores), av. Nações Unidas, r. Miralta, linha de transmissão da Eletropaulo, r. Massacá, r. General Furtado Nascimento, av. Arruda Botelho, pç Beethoven (pelo lado da quadra 126 do setor fiscal 82 da 
Planta Genérica de Valores), av. Professor Fonseca Rodrigues, r. Berlioz, r. Sucuriú, av. São Gualter e r. Cerro Corá até o ponto inicial

Z1-010

Começa na confluência da rua Caropá com a r. Livi, segue pela r. Livi, pç Vicentina de Carvalho, r. Caraçá, r. Aquiramum, r. Arquiteto Jaime Fonseca Rodrigues, r. Isabel de Castela, segmento 1-2 (divisa do lote 1, 3, 4, 5, 6, 7, 8, $9,10,11,12,13,14,15$ e 16 com os lotes $44,43,40,42,31,30,33,23,22$, 21,35 e 17 da quadras 282 do setor fiscal 81 da Planta Genérica de Valores), r. Pascoal Vita, r. Agostinho Bezerra, r. Ourânia, r. Soares de Aragão, r. Isabel de Castela, r. Natingui, r. Morás, pç Senador Lineu Prestes (pelo lado das quadras 202 e 213 do setor fiscal 81 da Planta Genérica de Valores), r. Morás, av. Pedroso de Morais, pç Roquete Pinto (pelo lado das quadras 4, 3, 2 e 14 do setor fiscal 83 da Planta Genérica de Valores), av. Professor Frederico Herman Júnior, av. nações Unidas, pç Arcipreste Anselmo de Oliveira (pelo lado das quadras 151, 150 e 149 do setor fiscal 82 da Planta Genérica de Valores), av. Professor Manuel José Chaves, segmento 3-4 (divisa dos lotes 5, 4 e 3 com os lotes 9 e 8 da quadra 144 do setor fiscal 82 da Planta Genérica de Valores), segmento 4-5 (divisa do lote 7 com o lote 8 da quadra 144 do setor fiscal 82 da Planta Genérica de Valores), av. Antônio Batuíra, segmento 6-7 (divisa do lote 7 com o lote 12 da quadra 145 do setor fiscal 82 da Planta Genérica de Valores), segmento 7-8 (divisa do lote 9 como o lote 11 da quadra 145 do setor fiscal 82 da Planta Genérica de Valores), av. Pedroso de Morais, segmento 9-10 (divisa do lote 4 com o lote 15 da quadra 188 do setor fiscal 81 da Planta Genérica de Valores), segmento 10-11 (divisa do lote $4 \mathrm{com}$ os lotes 18 a 29 da quadra 188 do setor fiscal 81 da Planta Genérica de Valores), segmento 11-12 (divisa dos lotes 12, 11 e 10 com os lotes 18 a 29 da quadra 188 do setor fiscal 81 da Planta Genérica de Valores), segmento 12-13 divisa do lote 6 com os lotes 18 a 29 da quadra 188 do setor fiscal 81 da Planta Genérica de Valores, segmento 13-14 (divisa do lote 6 com o lote 17 da quadra 188 do setor fiscal 81 da Planta Genérica de Valores), r. Arquiteto Jaime Fonseca Rodrigues, segmento 15-16 (divisa do lote 2 como o lote 11 da quadra fiscal 187 do setor fiscal 81 da Planta Genérica de Valores), segmento 16-17 (divisa do lote 4 com o lote 11 da quadra 187 do setor fiscal 81 da Planta Genérica de Valores), r. Dona Elisa de Morais Mendes, r. Doutor Carlos Norberto de Souza Aranha, r. Vitorino de Carvalho e r. Caropá até o ponto inicial

Z1-012

Começa na confluência da av. Rebouças com a r. Estados Unidos, segue pela r. Estados Unidos, av. Brigadeiro Luís Antônio, r. Paulino Camasmie, r. Manoel de Nóbrega, pç General Estilac Leal (pelo lado da quadra 84 do setor fiscal 36 da Planta Genérica de Valores), r. Manoel da Nóbrega, r. Bento de Andrade, r. Vieira Maciel, r. Groenlândia, r. General Mena Barreto, r. Oliveira Dias, r.

Primavera, r. Henrique Martins, r. Gironda, r. Groenlândia, av. Nove de Julho, av. Cidade Jardim, r. Gumercindo Saraiva, av. Brigadeiro Faria Lima, pç Itália (pelo lado da quara 76 do setor fiscal 15 da Planta Genérica de Valores) e av. Rebouças até o ponto inicial

Z1-013

Começa na confluência da av. Eusébio Matoso com a av. Brigadeiro Faria Lima, segue pela av. Brigadeiro Faria Lima, r. Campo Verde, r. Ceilão, viela sem denominação (cadlog 31.779-9), segmento 1-2 (divisa do lote 6 da quara 
226 do setor fiscal 83 da Planta Genérica de Valores com espaço livre), r. Carlos Millan, r. Ibipinópolis, r. Angelina Maffei Vita, r. Doutor Alceu de Assis, r. Doutor Alberto Carlos de Melo Neto, r. Hungria, av. Rebouças, r. ibiapinópolis e av. Eusébio Matoso até o ponto inicial

Z1-015

Começa na confluência da r. Colônia da glória com a r. Cláudio Rossi, segue pela r. Cláudio Rossi, r. Doutor Luiz Washington Vita, r. Comendador Júlio Pereira Lopes, r. Marcelino Champagnat, r. Doutor Valentino sola, segmento 12 (divisa do lote 85 com o espaço livre da quadra 145 do setor fiscal 39 da planta genérica de valores), segmento 2-3 (divisa do lote 40 com o espaço livre da quadra 145 do setor fiscal 39 da Planta Genérica de Valores),

segmento 3-4 (divisa do lote 40 com os lotes 177 a 192 da quadra 145 do setor fiscal 39 da Planta Genérica de Valores), r. Victor Dubugras e r. Colônia da Glória até o ponto inicial

Z1-016

Começa na confluência da r. Bento de Andrade com a av. República do Líbano, segue pela av. República do Líbano, segmentos 19-18, 18-17 e 17-16 (divisa da quadra 100 com a quadra 144 do setor fiscal 36 da Planta Genérica de Valores), av. República do Líbano, r. Diogo Jacomé, r. Domingos Fernandes, r. Escobar Ortiz, r. João Lourenço, r. Jacques Félix, r. Professor Filadelfo Azevedo, av. Santo Amaro, r. Bastos Pereira, r. Januário Miraglia e r. Bento de Andrade até o ponto inicial

Z1-018

Começa na confluência do segmento 2-1 com a avenida Ibirapuera, segue pela av. Ibirapuera, av. República do Líbano, al. Jauaperi, al. dos Jaúnas, r. Gaivota, r. Coronel Raul Humaitá Vila Nova, r. Canário, r. Coronel Raul Humaitá Vila Nova, r. Inhambú, r. Inajaroba, r. Euclides Parente Ramos, r. Afonso Brás, av. República do Líbano, av. Quarto Centenário, segmento 13-12 (divisa dos lotes 17, 16, 15, 14 e 13 com o lote 1 da quadra 145 do setor fiscal 36 da Planta Genérica de Valores), segmento 11-12 (divisa dos lotes 13, 12 , $11,10,9$ e 8 com o lote 1 da quadra 145 do setor fiscal 36 da Planta Genérica de Valores), segmento 11-10 (divisa dos lotes 8, 7, 6, 5 e 34 com o lote 6 da quadra 145 do setor fiscal 36 da Planta Genérica de Valores), av. Quarto Centenário, segmento 9-8 (divisa dos lotes 33, 31, 30, 29, 28, 27, 26 e 25 com o lote 35 da quadra 147 do setor fiscal 36 da Planta Genérica de Valores), segmento 8-7 (divisa dos lotes 25, 24 e espaço livre com o lote 35 da quadra 147 do setor fiscal 36 da Planta Genérica de Valores), segmento 7-6 (divisa do espaço livre e dos lotes 10, 9, 8, 4, 3, 2 e 1 com o lote 34 da quara 147 do setor fiscal 36 da Planta Genérica de Valores), av. Quarto Centenário, segmentos 5-4 e 4-3 (divisa do jardim público com o lote 19 da quadra 269 do setor fiscal 41 da Planta Genérica de Valores, segmento 3-2 (divisa dos lotes $19,10,9,8,7$ e 3 da quadra 269 com o jardim público do setor fiscal 41 da Planta Genérica de Valores) e segmento 2-1 (divisa do lote 4 da quadra 269 com o jardim público da quadra 269 do setor fiscal 41 da Planta Genérica de Valores) até o ponto inicial

Z1-019

Começa na confluência da rua Doutor Haberbeck Brandão com a av. Rubem Berta, segue pela av. Rubem Berta, av. Indianópolis, al. Iraé, Córrego Uberaba (divisa das quadras 108 e 107 com a quadra 93 do setor fiscal 41 da Planta Genérica de Valores), córrego Uberaba (divisa dos lotes 27, 26, 25, 24, 23, 22 , 
$21,20,19,18,17,16,15$ e 14 com o lote 10 da quadra 93 do setor fiscal 41 da Planta Genérica de Valores), segmento 1-2 (divisa do lote 14 com o lote 10 da quadra 93 do setor fiscal 41 da Planta Genérica de Valores), segmentos 2-3, 3-4 (divisa do lote 13 com o lote 10 da quadra 93 do setor fiscal 41 da Planta Genérica de Valores), av. Professor Ascendino Reis e r. Doutor Haberbeck Brandão até o ponto inicial

Z1-020

Começa na confluência da av. Bandeirantes com a r. Zacarias Góis, segue pela r. Zacarias Góis, r. Morais de Barros, córrego (divisa da quadra $413 \mathrm{com}$ a Quadra 430 do setor fiscal 86 da Planta Genérica de Valores), r. Vicente Leporace, r. Demóstenes, r. Confiteor, r. Cristóvão Pereira, r. Pascal, r. Zacarias de Góis, r. Demóstenes, r. Conde de Porto Alegre, r. Otávio Tarquínio de Souza, r. Barão do Triunfo, r. Doutor Jesuíno Maciel, r. Comendador Eduardo Saccab, r. Geórgia, av. Portugal, r. Luisiânia, r. Califórnia, r. Indiana, r. Arandu, r. Furnas, r. Porto Martins, r. Guararapes, avenida Nova Independência, r. Macambará, r. Porto Martins, r. Kansas, r. Ribeiro do Vale, r. Cabo Verde, r. Juruena, pç Coronel Fernandes de Lima, r. Inhambu, av. João Castaldi ou dos Eucaliptos, av. Ibirapuera, acesso esquerdo à avenida Ibirapuera e Avenida dos bandeirantes até o ponto inicial z1-021

Começa na confluência da r. Luís Góis com a av. José Maria Whitaker, segue pela av. José Maria Whitaker, incluindo: r. Existente (cadlog 33.006-0), r. particular sem denominação (cadlog 67.433-8), córrego (divisa dos lotes 3, 5, $7,8,87,11$ e 103 com os lotes 76 e 30 da Quadra 28 do setor fiscal 47 da Planta Genérica de Valores), córrego (divisa dos lotes 63, 105, 106, 68, 69, 70, $180,72,74,76,77,78,79,80,81,82,83,84,85,86,87,88,89,90$ e 91 com os lotes $62,95,102,111,110,17$ e 11 da quadra 278 do setor fiscal $47 \mathrm{da}$ Planta Genérica de Valores), córrego (divisa da quadra 76 com as quadras 278 e 279 do setor fiscal 47 da Planta Genérica de Valores), córrego (divisa dos lotes 1, 2, 3, 4, 5, 6, 7, 8 e 9 com os lotes 18, 17, 16, 57 e 10 da quadra 279 do setor fiscal 47 da Planta Genérica de Valores), córrego (divisa dos lotes $16,12,11,10$ e 9 com o lote 6 da quadra 96 do setor fiscal 47 da Planta Genérica de Valores), segmento 9-8 (divisa do lote 4 com o lote 5 da quadra 96 do setor fiscal 47 da Planta Genérica de Valores), segmento 7-6 (divisa dos lotes $3,12,11,23,10,8,7,6$ e 18 com os lotes $39,24,38,37,36,35,34,33$, 32 e 31 da quadra 27 do setor fiscal 47 da Planta Genérica de Valores), al. dos Tupinás, av. Indianópolis, r. Botuí, av. Ceci, al. dos Ubiatans, av. dos

Bandeirantes, r. Marechal Caetano de Faria, r. Jurandir, linha de transmissão da Eletropaulo, av. dos Bandeirantes, segmento 2-1 (divisa dos lotes 12 e 13 com o lote 64 da quadra 512 do setor fiscal 89 da Planta Genérica de Valores), linha de transmissão da Eletropaulo, viaduto João Julião da /costa Aguiar, av. Moreira Guimarães, av. Aratãs, av. dos Araés, av. Jandira, av. Moreira Guimarães, av. Rubem Berta e r. Luís Góis até o ponto inicial.

z1-34

Começa na confluência da r. Gregório Paes de Almeida com a r. Dona Elisa de Morais Mendes (divisa do espaço livre com a quadra 330 do setor fiscal 81 da Planta Genérica de Valores), segue pela r. Dona Elisa de Morais Mendes, $r$. Andrade Fernandes, r. Alvilândia, pç Professora Emília Barbosa Lima, r. padre Cerda, r. Sebastião Rodrigues, r. Caminha de Amorim, r. Bernarda Luiz, r. Livi, r. Caropá, r. Vitorino de Carvalho, r. Doutor Carlos Norberto de Souza Aranha, 
Praça São Gonçalo (pelo lado da quadra 76 do setor fiscal 81 da Planta Genérica de Valores), r. Japiaçóia, r. Engenheiro Sá Rocha, r. Boquim, r. Aldo de Azevedo, r. Doutor Luís augusto de Queiróz Aranha, r. Aefuca, r. Doutor Alberto Seabra, r. Sarará e r, Gregório Paes de Almeida até o ponto inicial. Corredores comerciais de zonas estritamente residenciais (Z-1): al. dos Tupinás, al. dos Ubiatans, av. Almirante Pereira Guimarães, av. Arnolfo Azevedo, av. Ascendino Reis, av. Brig Luis Antônio, av. Ceci, av. das Corujas, av. das Nações Unidas, av. Diógenes Ribeiro de Lima, av. dos Bandeirantes, av. Doutor Arnaldo, av. Eusébio Matoso, av. Faria Lima, av. Heitor Penteado, av. Ibirapuera, av. Indianópolis, av. José Maria Whitaker, av. Moreira Guimarães, av. Padre Pereira de Andrade, av. Pedroso de Moraes, av. Queiróz Filho, av. Rebouças, av. República do Líbano, av. Rubem Berta, av. Santo Amaro, av. São Gualter, av. Sumaré, pç. Arcipreste A. de Oliveira, pç. Irmão Karman, pç. Redenção da Serra, r. Aecri, r. Agostinho Bezerra, r. Alagoas, r. Aldo de Azevedo, r. Aliança Liberal, r. Alves Guimarães, r. Amália de Noronha, r. Andrade Fernandes, r. Araioses, r. Armando Penteado, r. Ásia, r. Aurélia, r. Bahia, r. Belmonte, r. Bento de Abreu, r. Bento de Andrade, r. Berlioz, r. Botui, r. Cabo Verde, r. Campo Grande, r. Cardoso de Almeida, r. Catalão, r. Ceará, r. Cerro Corá, r. Cipriano Juca, r. Cláudio Rossi, r. Colômbia, r. Colônia da Glória, r. Coronel Firmo da Silva, r. Dom Rosalvo, r. Domingos Fernandes, r. Dona Elisa de Moraes Mendes, r. Doutor Luz W. Nila, r. Epeira, r. Estados Unidos, r. Filinto de Almeida, r. Gavião Peixoto, r. General Furtado Nascimento, r. Gironda, r. Guaçu, r. Ibiapinópolis, r. Ibiraçu, r. Iperó, r. J. A. Castelo Branco, r. Jaciporã, r. Jarianos, r. João Castaldi ou av. dos Eucaliptos, r. João Lourenço, r. José Daniel, r. José de Freitas Guimarães, r. Júlio P. Lopes, r. Juranda, r. Luís César Pannain, r. Marcelino Champagnat, r. Maria Leonete da Silva Nóbrega, r. Miguel Rodrigues, r. Minas Gerais, r. Monte Pascal, r. Montevidéu, r. Morás, r. Natingui, r. Oliveira Dias, r. Pascoal Vira, r. Passos da Pátria, r. Patápio Silva, r. Paumari, r. Pedro Coelho, r. Pedro da Costa, r. Pio XI, r. Piraí, r. Plínio de Moraes, r. Ponta Porã, r. Primavera, r. Princesa Leopoldina, r. Prof. Alfonso Bovero, r. Prof. Filadelfo Azevedo, r. Prof. João Arruda, r. Sebastião de Amorim, r. Soares Aragão, r. Urbanizadora, r. Vanderlei, r. Vargem de Cedro, r. Victor Dubugras, r. Visconde de Indaiatuba 
7.2 - TRANSPARÊNCIAS PARA SOBREPOSIÇÃO DE MAPAS 